\title{
Cities, Autonomy, and Decentralization in Japan
}

Japan is known as a country in which a potent central power reigns over a compliant hierarchy and, for planning, this has meant strong centralized government control. Nevertheless, examples of autonomy have always existed in the politics, society, and economy of Japan and thrive today in various forms, particularly within urban areas. Following the growth and subsequent collapse of the bubble economy in the early 1990s, and in response to globalization, new trends toward local autonomy and political and economic decentralization are emerging that must be evaluated in the context of Japan's larger political and socioeconomic setting as it becomes increasingly integrated into the global system.

Cities, Autonomy, and Decentralization in Japan addresses these new initiatives, providing a cogent compilation of case studies focusing on the past, present, and future of decentralization in Japan. These include small-scale developments in fields such as citizen participation (machizukuri), urban form and architecture, disaster prevention, and conservation of monuments.

The book offers the first in-depth analysis of this development outside Japan, approaching the subject from a unique urban studies/planning perspective as opposed to the more common political science method. With contributions from a leading group of international scholars on Japanese urban planning, Cities, Autonomy, and Decentralization in Japan provides a valuable new addition to the current English-language literature.

Carola Hein is Associate Professor in the Growth and Structure of Cities Program at Bryn Mawr College, USA.

Philippe Pelletier is Professor of Geography at Lumière-Lyon 2 University, France. 
Routledge Contemporary Japan Series

1 A Japanese Company in Crisis Ideology, strategy, and narrative Fiona Graham

$2 \quad$ Japan's Foreign Aid

Old continuities and new directions

Edited by David Arase

3 Japanese Apologies for World War II

A rhetorical study

Jane W. Yamazaki

4 Linguistic Stereotyping and Minority Groups in Japan

Nanette Gottlieb

5 Shinkansen

From bullet train to symbol of modern Japan

Christopher P. Hood

6 Small Firms and Innovation Policy in Japan

Edited by Cornelia Storz

7 Cities, Autonomy, and Decentralization in Japan

Edited by Carola Hein and Philippe Pelletier 


\section{Also by Carola Hein}

Carola Hein (ed.), Bruxelles, siège majeur de l'Union Européenne: Capitale de qui? Ville de qui? (Brussels: major seat of the European Union: Whose capital? Whose city?), Brussels: Cahiers de la Cambre-Architecture 5, 2006 (forthcoming).

Carola Hein, The Capital of Europe: Architecture and Urban Planning for the European Union, Westport, CT: Greenwood/Praeger, 2004.

Carola Hein, Jeffry Diefendorf, and Yorifusa Ishida (eds.), Rebuilding Urban Japan after 1945, London: Palgrave Macmillan, 2003.

Carola Hein (main editor and author), Hauptstadt Berlin, internationaler städtebaulicher Ideenwettbewerb 1957/58 (Capital Berlin. The international urban planning idea competition 1957/58), Berlin: Gebr. Mann, 1991.

\section{Also by Philippe Pelletier}

Philippe Pelletier (ed.), Identités territoriales en Asie orientale, Paris: Les Indes Savantes, 2004.

Philippe Pelletier, Idées reçues, le Japon, Paris: Le Cavalier Bleu, 2004.

Philippe Pelletier, Japon, crise d'une autre modernité, Paris: Belin, 2003.

Philippe Pelletier, La Japonésie, géopolitique et géographie historique de la surinsularité au Japon. Paris: CNRS Editions, Shibusawa-Claudel Prize (1998), Grand Prize of the French Marine Academy (1999). 



\section{Cities, Autonomy, and Decentralization in Japan}

\section{Edited by Carola Hein and Philippe Pelletier}


First published 2006 by Routledge

Published 2017 by Routledge

2 Park Square, Milton Park, Abingdon, Oxon OX14 4RN

711 Third Avenue, New York, NY 10016

Routledge is an imprint of the Taylor \& Francis Group, an informa business

Copyright (C) 2006 Editorial selection, Carola Hein and Philippe Pelletier; individual chapters, the contributors

Typeset in Times by Prepress Projects Ltd, Perth, UK

The Open Access version of this book, available at www. tandfebooks. com, has been made available under a Creative Commons Attribution-Non Commercial-No Derivatives 4.0 license.

British Library Cataloguing in Publication Data

A catalogue record for this book is available from the British Library

\section{Library of Congress Cataloging in Publication Data}

Cities, autonomy, and decentralization in Japan/edited by Carola Hein and Philippe Pelletier

p. cm. -- (Routledge contemporary Japan series)

Includes bibliographical references and index.

1. Decentralization in government - Japan. 2. Central-local government relations - Japan. 3. City planning - Japan. I. Hein, Carola. II. Pelletier, Philippe, 1956- III. Series.

JS7373.A3C57 2006

$320.8^{\prime} 5^{\prime} 0952-\mathrm{dc} 22$

2005020303

ISBN13: 978-0-415-32603-2 (hbk) 


\section{Contents}

List of figures $\quad$ ix

List of tables $\quad$ xi

List of contributors xii

Preface and acknowledgments $\quad$ XV

1 Introduction: decentralization and the tension between global and local urban Japan 1

CAROLA HEIN AND PHILIPPE PELLETIER

2 Local initiatives and the decentralization of planning power in Japan

ISHIDA YORIFUSA

3 Concentration and deconcentration in the context of the Tokyo Capital Region Plan and recent crossborder networking concepts

NAKABAYASHI ITSUKI

4 Financial stress in the Japanese local public sector in the 1990s: situation, structural reasons, solutions

ALAIN SCHEBATH

5 Centralization, urban planning governance, and citizen participation in Japan

ANDRÉ SORENSEN

6 Machizukuri in Japan: a historical perspective on participatory community-building initiatives 
viii Contents

7 Whose Kyoto? Competing models of local autonomy and the townscape in the old imperial capital

CHRISTOPH BRUMANN

8 Conclusion: decentralization policies - questioning the Japanese model

CAROLA HEIN AND PHILIPPE PELLETIER

Select glossary of terms

Index

190 


\section{Figures}

1.1 The Japanese prefectures 6

1.2 The Japanese urban system (2000): cities (shi) with more than 200,000 inhabitants

1.3 Demographic evolution of Japanese cities with more than 100,000 inhabitants, 1980-2000

3.1 Conceptual plan for the Kanto region and Greater Tokyo (Toshi keikaku Tôkyô chihô iinkai) published in 1940 by Tokyo city planning local committee

3.2 Tokyo Green Space Plan 57

3.3 Land-use plan as part of the Reconstruction Plan for Tokyo 59

3.4 Sketches for regional planning as part of the reconstruction plan for Tokyo proposed by Ishikawa Hideaki

3.5 Comparison of development approaches proposed for the Capital Region by the National Capital Construction Committee (NCCC)

3.6 Conceptual plan for the development of the Capital Region by the National Capital Construction Committee (NCCC)

3.7 Comparison of the first National Capital Region Development (NCRD) Plan (1958) and the Greater London Plan (1944)

3.8 (a) Proposed concept for the second NCRD Plan. (b) The second NCRD Plan. (c) Highway network plan under the second NCRD Plan

3.9 (a) The changing concept of metropolitan structure under the third NCRD Plan: from unipolar to multipolar. (b) The third NCRD Plan. (c) Highway network plan under the third NCRD Plan

3.10 Conceptual draft plan for Capital Region Renewal Plan

3.11 (a) Conceptual drawing of the fourth NCRD Plan (1986): concentrated deconcentration concept for the Capital Region with a multinuclear sub-region. (b) The fourth NCRD Plan

3.12 Spatial relationship between the multipolar structure of the fourth NCRD Plan (1986) and the creation of sub-centers of the Long-term Plan for the Tokyo Metropolis 
$\mathrm{x} \quad$ List of figures

3.13 Conceptual drawing of the fifth NCRD Plan 76

3.14 Conceptual drawing for the Tokyo Megalopolis in 2050, proposed by the Tokyo Metropolitan Government

4.1 Evolution of the sources of revenues of the Japanese prefectures and municipalities from 1970 to 2000

$\begin{array}{lll}7.1 & \text { Territories of } \text { chô and jichi rengôkai } & 144\end{array}$

7.2 Area surrounding the site proposed for the Pont des Arts replica 147

8.1 Sites under consideration for possible relocation of the national capital of Japan 


\section{Tables}

4.1 Total amount of local debt and amount of local debt compared with the GNP

4.2 Evolution of the ratio of annuity to local revenues 85

4.3 Ratio of mandatory burden borne by Japanese local communities 86

7.1 Opinions of Kyoto citizens on townscape issues and measures that affect the value of and private control over real-estate property 


\section{Contributors}

Christoph Brumann has been a Lecturer in the Department of Ethnology at the University of Cologne, Germany, since 1999. He received his $\mathrm{PhD}$ in Ethnology in 1997 from the University of Cologne after completing undergraduate and postgraduate studies in anthropology, Japanology, and Sinology at the University of Cologne and Sophia University, Tokyo. In 1998-9 he completed an ethnographic field study in Kyoto as a Research Fellow of the National Museum of Ethnology (Minpaku), Osaka. He was the recipient of the Offermann-Hergarten award (Germany) in 1999 for Die Kunst des Teilens (The art of sharing).

Carola Hein is Associate Professor at Bryn Mawr College, Pennsylvania, in the Growth and Structure of Cities Program. She has published and lectured widely on topics in contemporary and historical architectural and urban planning. From 1995 to 1999 she was a Visiting Researcher at Tokyo Metropolitan University and Kogakuin University, focusing on the reconstruction of Japanese cities after World War II and the Western influence on Japanese urban planning. Her recent publications include The Capital of Europe: Architecture and Urban Planning for the European Union (Praeger, 2004); (with Jeffry Diefendorf, and Ishida Yorifusa) Rebuilding Urban Japan after 1945 (Macmillan/Palgrave, 2003); "Visionary Plans and Planners," in Nicolas Fiévé and Paul Waley (eds.) Japanese Capitals in Historical Perspective: Place, Power and Memory in Kyoto, Edo and Tokyo (Curzon, 2003); "Nishiyama Uzô and the Spread of Western Concepts in Japan," (10+1 20, 2000); and (with Ishida Yorifusa), "Japanische Stadtplanung und ihre deutschen Wurzeln" (Japanese urban planning and its German roots) (Die alte Stadt 3, 1998).

Ishida Yorifusa is Professor Emeritus at the Center for Urban Studies, Tokyo Metropolitan University, specializing in urban planning history and landuse policy. He is the author of numerous books, including Nihon Kindai Toshikeikaku Kenkyû (Studies in Japanese urban planning history) (Kashiwa Shobô, 1987); Mori Ôgai no toshi ron to sono jidai (Mori Ôgai's essays on urban problems in the context of his time) (Nihon Keizai Hyôronsha, 1999); and Nihon kingendai toshi keikaku no tenkai 1868-2003 (The development of Japanese modern and contemporary urban planning 1868-2003) (Jichitai Kenkyû-sha, 2004), among many other works. 
Nakabayashi Itsuki specializes in urban planning and disaster mitigation. He studied at the Department of Architecture at Fukui University and the Graduate School of Engineering at Tokyo Metropolitan University. From 1975 he was a Research Assistant in the Department of Geography at Tokyo Metropolitan University, where he became Associate Professor in 1987. Since 1993, he has been a Professor in the Center for Urban Studies, and since 1999 a Professor in the Graduate School of Urban Science, both at Tokyo Metropolitan University. He is a member of the Architectural Institute of Japan and the City Planning Institute of Japan.

Philippe Pelletier is Professor of Geography at Lumière-Lyon 2 University, France. He is the author of five books, four of which are on Japan, and more than 80 papers in his field. His publications include Le Japon (Le Cavalier Bleu, 2004). His Japonésie (CNRS Publications, 1997) won the ShibusawaClaudel Prize (1998) and the Grand Prize of the French Marine Academy (1999). He is co-director of NORAO (New Regional Organizations in East Asia), a group composed of 40 researchers from various scientific specialties within a research network of French geographers called GDR-Libergéo.

Alain Schebath holds a doctorate in town planning and urban development from the University of Paris-Val de Marne, and a master's degree in urban geography. He has served as a consultant at BIPE, one of the leading European providers of economic analyses, and the BETURE consulting and engineering firm, where he has conducted analyses of local finances, regional development policies, territorial marketing, and urban management. He spent close to four years in Japan as a guest researcher at Yokohama National University. He currently represents the Essonne Economic Agency, in charge of the development of relationships between Japanese regions and the BioTeam Paris Region, a network of core competencies in life sciences.

André Sorensen is Assistant Professor of Geography at the University of Toronto. He completed his doctorate in geography from the London School of Economics in 1998. He taught at the University of Tokyo Department of Urban Engineering from 1998 to 2002, and has published extensively on Japanese urbanization, urban planning and planning history. His publications include the book The Making of Urban Japan: Cities and Planning from Edo to the 21st Century (Routledge, 2002) as well as numerous articles including: "Building World City Tokyo: Globalization and Conflict over Urban Space" (Annals of Regional Science, Fall 2003); "Building Suburbs in Japan: Continuous unplanned change on the urban fringe" (Town Planning Review, Fall 2001); "Urban Planning and Civil Society in Japan: Japanese urban planning development during the 'Taisho Democracy' period (1905-31)" (Planning Perspectives, Fall 2001); "Subcentres and Satellite Cities: Tokyo's 20th Century Experience of Planned Polcentrism" (International Journal of Planning Studies, January 2001); "Land Readjustment, Urban Planning and Urban Sprawl in the Tokyo Metropolitan Area" (Urban Studies, December 


\section{xiv Contributors}

1999); and "Conflict, Consensus or Consent: Implications of Japanese Land Readjustment Practice for Developing Countries" (Habitat International, December 1999).

Watanabe Shun-ichi J. is Professor Emeritus of Urban Planning at the Department of Architecture, Tokyo University of Science. He has published and lectured widely in the area of comparative planning, on the United States, Great Britain, and Japan. His specialties also include Japanese machizukuri (community-building) and comparative planning in Japan, Korea, and Taiwan. Formerly with the Building Research Institute, Ministry of Construction, he has been a Visiting Professor at Michigan State University and the University of Washington. Among the English titles of his publications in Japanese are Amerika toshi keikaku to komyuniti rinen (American urban planning and the community idea) (Gihodo Shuppan, 1977); Hikaku toshi keikaku josetsu: igirisu Amerika no tochi riyo kisei (Introduction to comparative urban planning) (Sanseido, 1985); “Toshi keikaku” no tanjo: kokusai hikaku kara mita Nihon kindai toshi keikaku (The birth of urban planning) (Kashiwa Shobo, 1993); Shimin sanka no machizukuri: master-plan zukuri no genba kara (Machizukuri by citizen participation: reports from the field of master-plan making) (Gakugei Shuppansha, 1999); and (with Ôta Moriyuki) Shimin-ban machizukuri puran: jissen gaido (Practical guide to citizen-made machizukuri plans) (Gakugei Shuppansha, 2001). 


\section{Preface and acknowledgments}

Japan is known as a country in which a potent central power reigns over a compliant pyramidal hierarchy. For planning this has meant strong centralized government control. Yet, examples of autonomy have always existed in the politics, society, and economy of Japan and thrive today in various forms, particularly in urban areas. Following the growth and subsequent collapse of the bubble economy in 1990, and in response to globalization, new trends toward local autonomy and political and economic decentralization are emerging that must be evaluated in the context of the larger socio-political system. While the Tokyo megalopolis and other urban areas have been increasing in size and diversity of functions, both centralized authority and its expressions in planning are being questioned on various levels of Japanese government, among citizens, and in academia.

At a time when Japan is ever more integrated into the global system, attempts at autonomy occur on the level of the neighborhood, the city, the region, and the islands. Small-scale developments and community-building (machizukuri), disaster prevention, urban form and architecture, and protection of monuments and townscapes are flourishing. While the cities remain major centers for these initiatives, regions are making their own attempts at autonomous development or inter-regional collaboration. However, although the politics of "decentralization" have reached an unprecedented level of discussion at the beginning of the twentyfirst century, concrete results have yet to materialize.

While Japanese researchers are starting to analyze these initiatives, most of them are still largely ignored outside Japan. This book introduces recent scholarship and discussion by leading Japanese and foreign researchers to an English-speaking audience, focusing on questions such as: What concepts are being discussed in regard to autonomy in Japan and by whom? How do planning concepts seemingly as diverse as spatial decentralization, deconcentration, and machizukuri fit into the broader framework of autonomy and political and economic decentralization? How much freedom is there for initiatives emerging from outside the national government to enhance autonomy in a world directed by finance and the state? Are initiatives undertaken by individuals or small groups capable of instigating change and, if so, in what way?

The origins of this book go back to the 1997 conference of the European Association for Japanese Studies (EAJS) in Budapest, when Carola Hein and 
Philippe Pelletier were selected to organize the Urban and Environmental Studies Section of the ninth EAJS conference in Lahti, Finland, in 2000. Our call for papers entitled “Autonomy and Decentralization - Myth or Reality?" found interest among scholars in Japan, Europe, and the United States. At the 2000 conference 28 researchers presented papers on issues ranging from urban deconcentration by the state and in the megalopolis to issues of policy in small and mediumsized towns, as well as on the themes of machizukuri and citizen action. While all the contributions were excellent, because of limitations of space and scope we selected six papers that - after extensive expansion and revision - became the core of the present book.

The endeavor brings together scholars from a variety of disciplines (urban planning, geography, economics, history, and anthropology) and geographical backgrounds, whose complementary approaches paint a comprehensive and interdisciplinary picture of decentralization issues in Japan. The book introduces the topic with an overall investigation of the Japanese political and economic system and its expression in spatial restructuring. It then turns to the historical development of urban decentralization in Japan and a discussion of deconcentration inside the Tokyo metropolis. These pieces are followed by an analysis of issues of local financing, civil society, and urban governance. Finally, the book explores the history and contemporary status of machizukuri and civil society, before ending with a more general consideration of the current state of decentralization, nationally sponsored public works, the concept of capital city relocation, and the examination of decentralization in the context of globalization.

We wish to thank all the participants in the Lahti conference for their engaged discussion during our meeting. Special gratitude goes to Bryn Mawr College for logistical and financial assistance with the creation of this book. We also wish to thank Stephanie Salomon for her editorial help, Marie-Laure Trémélo for help with the production of some of the maps, and our editor at Routledge. We are extremely grateful to our families for their encouragement. Carola wishes in particular to thank Caya, Aliya, Jolan, Patrick, Wuppi and Walter, who have traveled with her and supported her over many years with love.

\section{Note on spelling}

In keeping with Japanese custom, Japanese proper names appear in this volume with the surname followed by the given, first name (unless the authors are based outside Japan). Long vowels are indicated by circumflexes, but well-known place names (Tokyo, for example) are written without circumflexes, as is conventional in English. Japanese names are provided for agencies, institutions, and legal documents, in order to make it easier to locate them. 


\title{
1 Introduction
}

\section{Decentralization and the tension between global and local urban Japan}

\author{
Carola Hein and Philippe Pelletier
}

Since World War II, urban planning in Japan has undergone a profound transformation, despite important political and economic continuities. The last two decades in particular have seen major changes in terms of urban governance and relations between the center and the periphery, the national government, the municipalities, and the citizenry (DeWit 1998). The ongoing process of the redistribution of political power and financial responsibilities as well as spatial restructuring are particularly visible in the relationship between the capital city, Tokyo, and the peripheral areas and fall under the broad headings of "decentralization" and "autonomy." Although the problematic relationship between center and periphery is a thread that runs through Japanese history (Fukashi 1996), many of these changes are rooted in the "rapid growth" phase of the 1960s and in new technological and socioeconomic conditions (the culture of the automobile and the high-speed train, for example).

The New City Planning Act of 1968 (shin toshi keikaku hô) - despite the fact that many of its original ambitions were unrealized (see also Chapters 2 and 5 by Ishida Yorifusa and André Sorensen in this volume) - and the creation of the first National Land Agency (Kokudochô) in 1974 reflected an attempt, at least in theory, to decentralize power and give more rights to citizens and local governments. Since the 1980s, the redistribution of political power has gone hand in hand with globalization, the relocation of Japanese industries overseas, and their insertion into the global financial economy, as well as redeployment within the boundaries of the Japanese archipelago and reconcentration within the megalopolises, most notably Tokyo (Berque 1993, 1994). Over the same period, the Japanese government has promoted decentralization through policy measures such as the new Law for the Promotion of Decentralization (chihô bunken suishinhô) issued in May 1995 (see Chapter 8 by Hein and Pelletier in this volume). At the same time, other policies effectively counteracted the transfer of national power to local institutions. Notably the reform of the central administration pursued since January 2001 - aimed at reducing the number of ministries and governmental agencies - has effectively reinforced the power and efficiency of the national government, raising multiple questions, such as: What are the political, economic, financial, social, and cultural contexts, ties, and interests that help to maintain the status quo of the highly centralized Japanese structure as well as those that push for a 


\section{Hein and Pelletier}

redistribution of political power, economic infrastructure, and population to the periphery? How does decentralization fit into the larger picture of public projects in Japan? How do globalization and the request for strengthened local powers fit into the discussion on decentralization and autonomy? In this complex discussion, the role of Tokyo is a special one. Questions that need to be answered include: What role do cities - and particularly the capital, Tokyo, as the political capital and economic metropolis, seat of the government, major companies, educational and cultural facilities - play in the context of centralization and decentralization?

\section{The capital city of Tokyo: the heart of decentralization policies}

The complexity of decentralization movements in Japan, and their implications for urban as well as many other issues, can only be understood through an analysis of the relationship between Tokyo - established as Edo by the Tokugawa shoguns in 1603 - and other urban areas in Japan. Following its creation, Edo quickly became one of the largest metropolises, if not the largest, of its time. Through the system of sankin kôtai (alternate attendance), provincial lords were required to regularly spend time in the shogunal capital, thereby increasing its population. The Meiji restoration in 1868 meant further centralization of politics and ultimately population in Tokyo. In the early years of modern Japan, the city experienced a steep decline in population, as the members of the provincial aristocracy returned to their home towns. This development left the center of the city outside the shogunal palace gates empty and ready to host new capital functions without having to displace or relocate citizens established in the area. As the population experienced a second rapid increase in the late nineteenth century, Tokyo became home to the national government and a new business district - located just outside the shogunal palace - and major infrastructure programs, including a new railway and the Tokyo station.

The history of decentralization movements in Japan, examined by Ishida Yorifusa in Chapter 2, begins with the chaotic Meiji period, during which individual cities embarked on many planning initiatives. The plans for Tokyo, however, in spite of requests for more local autonomy, were conceived as national projects from 1888 on. The central government's dominion over Tokyo's planning affairs culminated in the 1919 City Planning Law (1919 nen toshi keikaku hô or kyû toshi keikaku hô) and the Urban Building Law (shigaichi kenchikubutsu hô) of 1919, which put urban planning under the control of national law and may be seen as a high-handed approach toward centralizing planning, to the detriment of local initiatives. As the major showcase for government power, both within Japan and beyond its borders, it was essential that the capital city of Tokyo display effective national leadership and serve as a model.

Beginning with the Meiji era a double contradiction developed: first, among the various types of spatial concentration (urban, industrial, and tertiary) favoring the extension of Tokyo over the balanced development of rural areas; second, 
between the state and the special Tokyo government faced with the difficult administration of an increasingly complex new urban body. Like other cities, Tokyo's urban planning was strictly controlled by the Ministry of the Interior (Naimushô), which at the time appointed mayors and exercised direct authority over urban planning and which strongly opposed local governance, particularly in Tokyo. The national government needed its principal sites to function appropriately and it did not want to equip the capital with too much local power. For the Meiji period leaders the capital was meant to represent the central authority. In many East Asian nations, both communist and democratic, ancestral Asian despotism has left a legacy of dominance by a single authority, which is reflected in a strong, central capital city. These common aspects led to a developmental ideology and national strategy aimed at propelling the country out of underdevelopment - compared with the leading European countries and the United States - and an urge to "catch up" that is particularly pronounced not only in Japan but also in Korea and to a certain extent in China. From this perspective, the state policy toward development is articulated logically and naturally around nationalism and planning based in national ideologies. ${ }^{1}$

Following the Meiji restoration, the traditional understanding of the capital had to adapt to the changing needs of a modern metropolis. The political and administrative organization of the Japanese capital was revised several times between 1868 and 1945, reflecting the difficulties of finding common ground. ${ }^{2}$ While both the Municipal code (shisei) and the Town and Village code (chôsonsei) enacted in 1888 provided relative autonomy for the Japanese local entities (shi chô son), in August of that year, Tokyo became the first city in Japan to have urban legislation. Instead of elected mayors, a prefect was designated by the central government, and the city of Tokyo (Tôkyô-shi) was formed, composed of 15 wards $(k u)$, the designated administrative units of major cities. From 1898 on, voters elected the Tokyo municipal assembly, but its president remained under the tight control of the Ministry of the Interior. In October 1932, the perimeter of Tokyo expanded when 82 neighboring communes were included to form 20 new wards. In the intervening time the law of 1919 and the 1923 reconstruction plan following the Great Kanto Earthquake had been established and provided a framework for Tokyo's urban planning.

The centralization of Japanese planning was fully established in the 1930s - as the Fifteen Years War (jûgonen sensô), which led directly to the country's involvement in World War II, intensified - and only a few local initiatives still remained, among them the land-readjustment initiatives emanating from Nagoya under urban planners such as Ishikawa Hideaki and Kaneiwa Den-ichi. During the war years (1930-45), the first attempts at decentralization also occurred, with the relocation of industrial production and related industries to the outskirts of cities as a means to protect them from Allied bombing. Before the military defeat of World War II, in July 1943, the prefecture $(f u)$ and the city $(s h i)$ of Tokyo merged into a single capital city entity: Tôkyô-to. Each of the central, original wards of Tokyo was given the status of city, with the governor responsible for the admin- 
istration of the whole. At the height of the war the creation of a larger Tokyo with limited autonomy reflected the national desire to centralize and promote Tokyo as a structural model.

Postwar reconstruction, however, largely revolved around the central government, as local cities lacked the manpower and financial means to develop and implement plans (Hein, Diefendorf, and Ishida 2003). This highly controlled system did not disappear with the first local elections in 1947. American attempts at decentralization, such as that embodied in the so-called Shoup Mission of 1949 - named after Carl Sumner Shoup, an American economist, who studied Japan's tax system and recommended revisions in 1949 - existed but the 1919 law remained virtually unchanged until 1968, when citizen movements spurred reform. The national government remained in control, particularly in regard to financing (Ansart 1995; Hagihara 1998; Shigemori 1998). The status of Tôkyô-to was preserved and the head of the prefecture became a governor, to be elected every four years. The city wards were reorganized and their number was reduced from 35 to 23. Each ward elected mayors, but their powers were fewer than those of other communes (even the Tokyo communes outside the central wards). Between 1952 and 1972 direct elections were even abolished inside Tokyo. The particular administrative and political history of Tokyo led to the creation of a political-administrative structure that is at odds with its urban geography.

The ambiguous role of Tokyo is reflected in its name. The term to reveals this confusion. Although its literal translation is "capital", ${ }^{3}$ making its governing body the Tokyo Capital Government (Tôkyô tochô), official statements translate the term as "metropolis" and thus identify the main authority as the Tokyo Metropolitan Government (TMG). This confusion is furthered with the generalized use of the term daitoshi, meaning "big city" or "metropolis," which can mean either the "metropolitan area" of Tokyo within a 50-kilometer radius from the center (of Tokyo) (Tôkyô daitoshi-ken) or the 15 special-status cities. ${ }^{4}$ Since the 1930 s, the urban development of Tokyo has in fact witnessed two trends that complement each other, as Nakabayashi Itsuki points out in Chapter 3. On the one hand, the city attracts and nourishes central economic, political, and cultural functions for Japan as a whole; on the other, many of these functions are being relocated to the larger periphery of the city, often even beyond the administrative boundaries of Tôkyô-to, a development that is discussed in this volume under the term "deconcentration."

The size and power of both Tokyo and the central government create tension between the two. In Japan, the provinces (chihô) - which can also be characterized as "non-Tokyo," the Japan beyond Tokyo - begin right outside the capital of Tokyo. Yokohama, only some 25 kilometers from Tokyo, is thus considered part of the provinces. The word chiho literally translates as "on the side of the earth," encompassing not only rural Japan but also the major cities located in this area, including Osaka and Nagoya, and even the iconic ancient capital of Kyoto. The conception of the railway system mirrors Tokyo's central position relative to the rest of Japan. Tokyo is the heart of all railway lines that "go up to the capital" (jôkyô) or "go down to a province" (gekô). 
Parts of the provinces, such as Yokohama, are located just outside the administrative area of Tôkyô-to, and are effectively part of the larger metropolitan area of Tokyo. Their elected officials, however, do not have the same status as the governor of Tokyo and feel to some extent dominated by the capital. They were among the first that, supported by citizen movements, agitated in the 1970s for an equalization of the various Japanese territorial and governmental entities and for the "era of the provinces" (chihô no jidai). ${ }^{5}$ More recently, the term chihô has also been used to refer to "local" (chihô jichitai) (Abe and Yorimoto 1988). Tokyo itself is a local entity, a situation that reflects the complexity of the topic and the relations between the different territorial actors.

The dichotomy between Tokyo and the provinces could also be taken to mean the larger urban area versus all areas beyond, something that is difficult to delineate precisely. ${ }^{6}$ In recent years, the strict separation between Tokyo and the provinces has begun to disappear even in administrative terms. The former National Land Agency, subsumed by a larger ministry in January 2001, distinguishes two spatial categories based on the prefecture (ken): the 15 metropolitan prefectures (daitoshiken) and the 32 provincial prefectures (chihô-ken). According to this conception, the province (chihô) is thus everything that is not metropolitan (daitoshi). The difficulties of defining national and local levels of administration and the center and periphery of urban and rural areas highlight the complexity of the analysis of issues of decentralization, deconcentration, and local autonomy in Japan.

From a political and administrative point of view, the central, national authorities (government, ministries, and the national administration) are often distinguished from the local governments (jichitai), which include the prefectures (todôfuken) and the urban and rural communes (shi chô son) (Figure 1.1). There are more than 65,000 local elected representatives and almost 3,300 heads of local governments. Local governments employ some 2.8 million people (1996), more than the 1.5 million who work for the central government. With budgets larger than that of the national government, local governments thus make up a huge part of the public sector (Jain 1999: 118). These statistics highlight the ongoing struggle between the various central and local constituencies. ${ }^{7}$

The relationship between the national capital and the local governments exists on three levels: political, administrative, and financial. As Alain Schebath explains in Chapter 4, local budgets depend for one-third on central government transfers of funding. Another third comes from local taxes (chihô zei), with the final third deriving from local bonds (chihôsai), which need to be approved by the national government (specifically the Ministry of Autonomy), active revenues, and other resources. The national government, through the allocation of these monies, controls their spending to a significant extent (see Namikawa 1996).

One of the characteristics of the financial system is a distribution arrangement, instituted following the work of the Shoup Mission and recommendations by the Kanbe Committee in $1949-50,{ }^{8}$ which was meant to assist all local governments equally (Hill and Kim 2000). While this system provides essential aid for local entities experiencing financial difficulty, it has also been criticized for penalizing wealthy communities and favoring peripheral regions with fewer resources. 


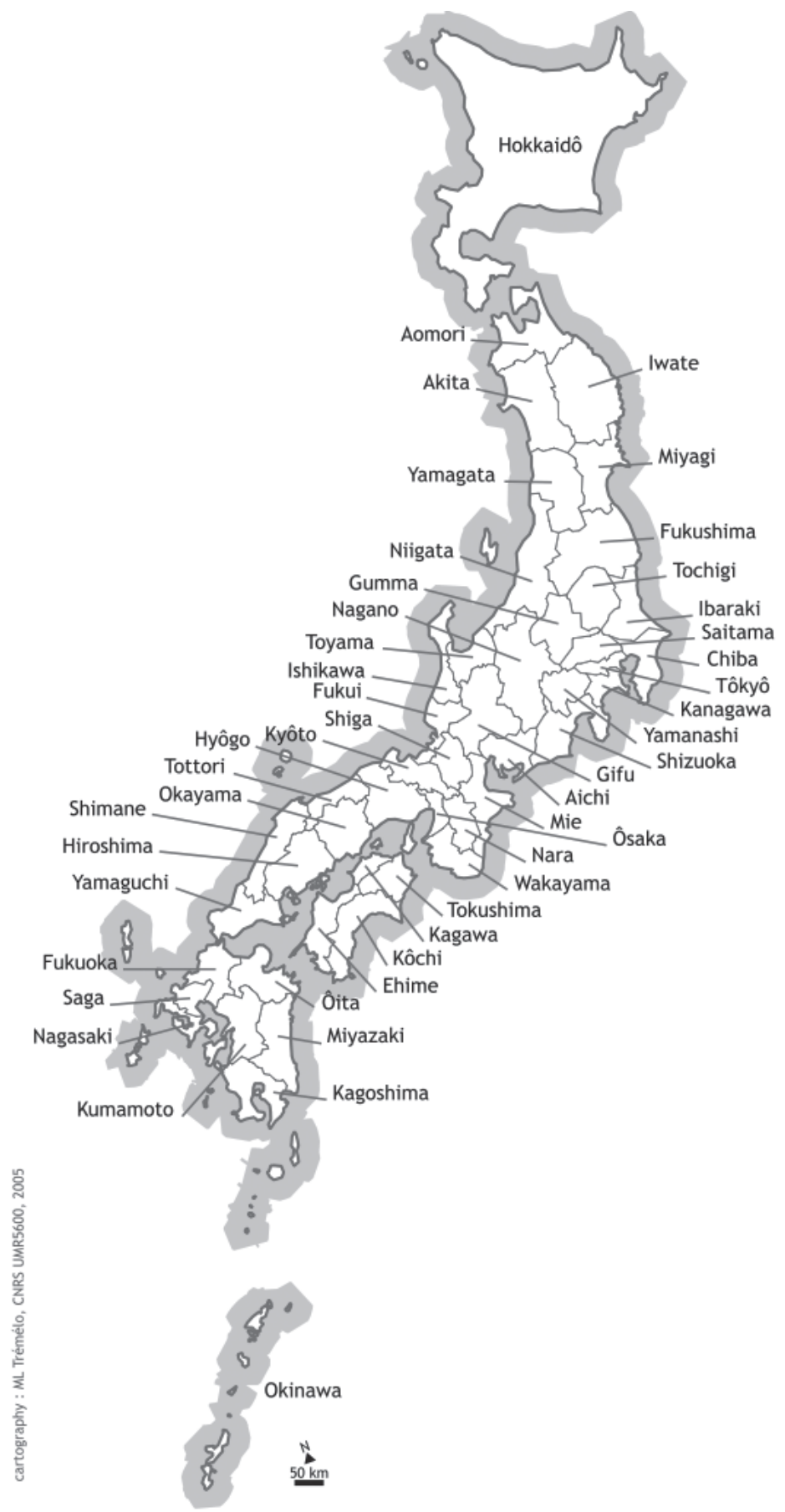

Figure 1.1 The Japanese prefectures. 
Furthermore, public services (infrastructure, health, welfare, and education) are the financial responsibility of the local governments even though they are largely administered by the national government. Thus, sociologists Richard Child Hill and Kuniko Fujita have concluded that "the center collects two-thirds of the nation's taxes and then reroutes half back to local governments" (Hill and Fujita 2000), effectively using local taxes for national funding. This system is one reason for geopolitical tensions. As Schebath points out, the fiscal crisis of the 1990s and early 2000s has led to financial problems for Japan's local public sector even as decentralization has given local governments increased opportunities to generate new taxes.

Granting more power to local governments and revising the system of urban governance and citizen participation raises questions about the role that the long existence of centralization has played in shaping local urban governance in Japan (Numata 1996). In Chapter 5 André Sorensen investigates the issue of civil society - a concept that some have considered absent in Japan while others have highlighted the existence of numerous citizen representations. Sorensen points to long-standing traditions of self-governance in Japan and discusses their particular characteristics, while examining how citizen groups have been co-opted into a hierarchical governmental system under national leadership or kept comparatively small, local, and irrelevant on a national level.

In Chapter 6, Watanabe Shun-ichi continues this line of investigation by specifically addressing the advent of machizukuri (community-building) in Japan and its effect on urban planning. Analyzing various neighborhoods that have taken on essential functions in the development of machizukuri in Japan, Watanabe examines the planning tools that have been employed by these initiatives and suggests that citizen participation should be essential to municipal decisions made in relation to urban planning. To make this possible, a legal system is necessary that provides an appropriate framework for participation and citizens need to have the appropriate skills and support from the municipality.

Christoph Brumann studies a specific example of citizen participation in Japan in Chapter 7, examining the impact of local autonomy and self-rule on decisions concerning the historic Kyoto townscape. Using a social-anthropological approach, Brumann examines three different models of participation: traditional neighborhood organizations (chônaikai), citizen groups, and municipal dialogic approaches (often characterized as pâtonashippu (partnership)), focusing in particular on a proposal to build a replica of Paris's Pont des Arts in central Kyoto. Brumann's surprising finding is that an individualistic approach to landownership is present in Japan's society, stereotyped as collective.

The above explorations in this volume thus highlight the difficulties on the national as well as the local level in establishing a comprehensive decentralization of political power and urban self-determination. In spite of various quasi-federalist attempts in Japan's 1947 constitution, inspired by the American model, Japanese local governments have only relative autonomy vis-à-vis the central government. In addition, as the last three chapters in this book suggest, local initiatives have been constrained, with citizens receiving inadequate support to make informed 


\section{Hein and Pelletier}

decisions, as well as engaging in individualistic behaviors that work against a powerful, collective local representation.

The differences and tensions between the national and local levels in Japan are further exacerbated by globalization. The current relationships between the local and the national, and the local and the global, and the reorganization of local forces in Japan would be incomprehensible without an analysis of how Japan as a whole operates. This system, which can be described as "state capitalism," while challenged by the neo-liberal policies of the Nakasone government in the early 1980s, has been accelerated by globalization, particularly since the end of the Cold War. Chapter 8, in conclusion to the preceding essays, asks how current discussions on decentralization, the ongoing national government focus on public works, and the relocation of capital functions unfold in the context of globalization and localization. In order to frame the essays in this volume, the following discussion explores the features of the Japanese system, specifically the close cooperation of politics and industry since the postwar period and their expression in the economic and spatial trends since the 1960s, through the example of the development of "technopolises."

\section{Modern Japan: state capitalism and a war economy in peacetime}

The influence of the Japanese government is marked in all of the nation's economic activity, particularly that of the large industrial and commercial monopolies, and their physical location is partly an expression of clear national strategies. The state policy of creating great public works as an economic and spatial tool and means of national pride is often referred to as "the state as builder" (doken kokka) (see Chapter 8). This political scene has been dominated for the past half century almost continuously by the Liberal Democratic Party (LDP) - named for its advocacy of a liberalized economy and known commonly in Japanese as the Jimintô - a conservative party, which has been characterized by factional fights and obfuscating practices. Decision-making processes tend to be opaque and a techno-bureaucracy reigns that is powerful, anonymous, and omnipresent. All these elements would seem to cast Japan as a variation of the repressive, Sovietstyle state communism that existed during most of the second half of the twentieth century. But other factors militate against this similarity. Japan is clearly involved in an American alliance and consumerism is all-pervasive. Rather than a form of state communism, Japan can accurately be called, based on the ideas of Karel van Wolferen, a capitalist war economy in a time of peace (van Wolferen 1989).

The Japanese system can be broken down into two periods that have many elements in common: the first established in 1940, the second starting in 1955. In the early 1940s (before the defeat of 1945), Japan was organized along imperial-militaristic lines as a war economy with a national government intervening strongly in all the sectors of economy and society. This strong interventionist policy was the result of a compromise between various political actors and numerous ideological tendencies: agrarian, ultra-nationalist, liberal-imperialist, and even Marxist. ${ }^{9}$ 
The economic and planning programs elaborated in the Japanese archipelago and in Manchuria during the 1930s served as models for managed economies and urban planning in the first half of the 1940s and again during postwar recovery, as the Marxist economist Arisawa Hiromi (1896-1988) has explained (Gao 1994; Hein 1994). A convergence emerged between the defenders of planning, more or less Marxists, and right-wing parties, based on a common recognition of imperialism and expansionism. Between the two dominant tendencies within the Japanese ruling class from the Meiji period to 1945, a strong expansionist desire characterized the liberals, whereas the conservatives were more pragmatic and concentrated on the archipelago (Norman 1975).

The war's destruction and the atomic bombing of Hiroshima and Nagasaki on August 6 and 9, 1945, did not result in a new Year Zero for Japan - a point at which the country made a fresh start - a claim often made in public statements by Japanese and foreign sources alike. Many of the political, economic, and social structures as well as the urban planning system put into place before the 1940s extended into the postwar period despite the American occupation and the desire of the occupation forces to democratize Japan (Dower 1999; Hein 2003a). Attempts at transforming Japan, including the new constitution promulgated in 1946-7 - which retained the emperor as the symbol of the nation in spite of his role in the militaristic period - took a new turn in 1948-9 when China embraced Maoism and the nationalists of the Guomindang took refuge in Taiwan (Hein, Diefendorf and Ishida 2003). This upheaval precipitated a change in the American occupation strategy. The Americans stopped the purging of the Japanese military, and only a handful of leaders, including Tôjô Hideki (1884-1948), were tried and executed. Other war criminals were released and quickly put into new, and often important, positions.

Subsequently, Japan was gradually promoted by the United States as a model and an alternative to the communist danger. With the Soviet Union remaining Stalinist and China becoming Maoist, Japanese communists were integrated into Japan's plan for rapid growth. This so-called "miracle" was in turn presented to East Asian and other Third World countries as a model for economic development. While Japan obtained political support from the United States, the Korean War, in 1950-3, provided help for its industry. The promotion of this system by both the American and the Japanese governments in the post-World War II period was less a new - American - way of life than a recycling of the system in place during the 1940s, as well as of its former leaders. ${ }^{10}$

In 1955-73, the years that became known as the "rapid growth" period, the Japanese war economy was given new life in a type of state-sponsored capitalism. The main difference from the war period was a democratic political system that included elections and freedom of the press. The "new" system, however, was compromised by the fact that the postwar LDP effectively functioned as a monolithic authority, crippling the government by nepotism and corruption.

One of the most important postwar changes was the dismantling of the formerly powerful Ministry of the Interior, which also oversaw local governments and urban planning. While urban planning was initially the domain of the Ministry 
of Construction (Kensetsushô), created postwar, and then partially of the National Land Agency, local governments became part of the new Ministry of Autonomy. Since that time, the national government has tried to recuperate the powers it lost after World War II. ${ }^{11}$

Throughout the postwar era and continuing more than 50 years later, provincial and rural representatives have assured the industrial and metropolitan destiny of Japan, exemplified by the hyper-concentration of Tokyo. Nonetheless, some structures inherited from the 1940 period continue to play an important role in urbanization, directly or indirectly. Land readjustment (kukaku seiri), for example, a technique refined after the 1923 earthquake, remains in effect to this day. ${ }^{12}$

\section{Economic and spatial trends since the 1960s: decentralization and technopolitan development}

The analysis of economic sectors generally considered at the helm of the Japanese economy and their spatial translation reveal a major aspect of regional rebalancing since the 1960s and highlight the particularities of Japanese decentralization. ${ }^{13}$ Technological invention and the location of the relevant industries often seem disconnected in Japan. The American occupation's authority over the ownership of the country's industrial sites, which lasted for more than 10 years following the end of World War II, had originally discouraged the Japanese, leading them to ignore research and development and instead import technology. As a result, a relative disconnection ensued between the business world and the universities, in which research affecting industry was conducted. Rather than advances made through research, competition between the various companies in regard to the improvement of imported technologies became paramount (Matsui 1998).

Decentralization of production sites began in the early 1960s when heavy industry in the Kyushu region (the southernmost of the four main Japanese islands) started to experience an economic crisis and major electronics companies moved there. ${ }^{14}$ The main reason for their move was the availability of a young, female workforce that was cheaper than the male workers in the metropolis and that initially did not require many qualifications. The area offered a good transportation network (airplanes, trains, highway), proximity to large cities in northern Kyushu, and a decade later on to the Asian market, as well as enthusiastic local politicians and the support of those at the national level. While several large factories moved their production sites to the provinces (particularly Kyushu or Tôhoku), research and development as well as production for the semiconductor industry remained in Tokyo (notably around Minato-ku and Shinagawa-ku and bordering districts in Kawasaki and Tama, in addition to suburban areas such as Mitaka) and Osaka, where the sophisticated machines used in the industry were made (Takeuchi 1993; Takeuchi and Mori 2001).

Industrial decentralization often occurred in several steps, as illustrated by the spatial strategy employed by the major software, semiconductor, and automobile industries, including NEC and Toshiba (Kitagawa 1994). The first step was marked by the expansion of companies (1960-70) to centers in the vicinity of 
Tokyo and other major cities. The second step (1970-80) saw an expansion into the provinces (Kumamoto, central Honshû, and Tôhoku) where cheap labor was a major argument for relocation. Third (1980-2000) was a return of activities to the vicinity of Tokyo, as the proximity to an airport and the existence of good trucking networks assumed primary importance. In the case of Toshiba, a clear spatial hierarchy exists, from the sophisticated headquarters plant in Ôme in the western suburbs of Tokyo, employing highly skilled workers, to the more labor-intensive processes located in the provinces and rural areas (Kashima 1995). ${ }^{15}$ Overall, the leading sectors of Japanese industry have begun reconcentrating in the Tokyo metropolis, which, in fact, has paved the way for a revitalization of some of the historically multifunctional and socially mixed urban districts characteristic of Japan and metropolitan regionalization toward adjacent areas (Ide and Takeuchi 1980). The effects of globalization, however, may also come to play a part in their socio-spatial structure.

These trends in the location of industries and their hierarchies have undergone a political and social evolution. Regional rebalancing (chihô bunken), labeled decentralization, became a major political concept at the end of the 1970s. The Third Comprehensive National Development Plan (sanzensô, 1977), which emphasized decentralization, criticized the accumulation of industrial and other headquarters in the unipolar center of Tokyo and suggested their redistribution. Its decentralization logic was nonetheless quickly eclipsed by the reinvigoration of the megalopolis and the relocation of industries there during the "bubble" period (1985-90). The Plan for the Reconstruction of the Capital (shuto kaizô keikaku, 1985) and the Fourth Comprehensive National Development Plan (yonzensô, 1986) project the relocation of only some headquarters functions into new business centers within the Tokyo megalopolis.

Only toward the end of the rapid growth period and as a result of the oil shock did the Japanese leadership, particularly the Ministry of International Trade and Industry (MITI), abandon importing technology and launch research and development as a close collaboration between the government and the private sector. By 1970, Japan had caught up, notably with the United States, which had been the primary source for imported technology. Shortly thereafter, other new technology sectors emerged and by the early 1980s Japan had developed sophisticated procedures in industries such as those producing semiconductors and electronic multi-media (Shimada 1998, Edgington 1994).

The rapid development of technological activity in conjunction with a recognition of the need for regional planning led to the development of plans for new towns focusing on these activities, the so-called "technopolises," a concept that had been discussed as early as 1977 in the National Science and Technology Agency. Soon after, MITI began to explore the same idea and inaugurated a "Technopolis Plan" in 1983, although the original impetus for this plan is unclear. Sociologist Kuniko Fujita points out that following the rapid growth period many local governments looked to high technology to spur regional development (Fujita 1990). ${ }^{16}$ It was the desire of the prefectures for a technopolis that led MITI to conceive many more than the two or three it had initially projected in its plan. 


\section{Hein and Pelletier}

The Technopolis Plan was a product of projects for new industrial cities (shin sangyô toshi) promulgated in a 1962 law, the same year as the first national plan, and of the famous kaizôron (Remodeling Plan) of 1972, proposed by Prime Minister Tanaka Kakuei (1918-93), whose book on the reconstruction of the Japanese archipelago (Nihon rettô kaizôron) became a blueprint for regional planning. The kaizôron integrates the political characteristics of the rapid growth period (1955-73), such as the construction of industrial complexes (konbinâto) and mass transportation, including the high-speed railway. It also introduced new elements such as the improvement of the quality of life and the environment and regional rebalancing. The project was left uncompleted following a series of political scandals surrounding Prime Minister Tanaka, economic instability due particularly to the oil crisis, and popular refusal to sacrifice quality of life to economic growth. However, at the beginning of the 1980s, during a new growth period, some of the planning ideas spelled out in the kaizôron became applicable. ${ }^{17}$ Among them were the planned infrastructure projects, including the bridges and viaducts on the Inland Sea and new airports. The only major difference was that the relocation of heavy industry in the northeast and southwest of the archipelago was abandoned in favor of the redistribution of new technology industries. The creation of 26 technopolises in 1983 was followed by the designation of 11 "research cores" (risâchi koa) in 1986, based on the "law for the promotion of the participation of private enterprise," better known as Minkatsu, proposed by MITI and financed by revenues gained following the privatization of Nippon Telephone and Telegraph (NTT).

Apart from the changes in the kinds of industry - from heavy chemicals in 1962-4 to high technology in the 1980s and 1990s - the plans of 1962, 1972, and 1982 were based on a similar spatial development. Just like the new industrial cities, the construction of the later technopolises privileged industrial investment and the participation of public (notably local) powers, and saw a late realization of basic necessities, including housing. In spite of their original ambitions, urban design questions were neglected. The locations of the two types of new construction differed: the 1960s industrial parks were situated along the Pacific Ocean, on plains, and on landfill sites, in contrast to the 1980s technopolises, which were built mainly in the hilly back country. The logic of their implantation was nonetheless similar to that of the rapid growth period. The technopolises were usually located close to major cities or major infrastructures associated with them. The technopolises that are most integrated into the major urban centers - Utsunomiya,

Kôriyama, Shinanogawa, Hamamatsu, Kibi-Kôgen, Kumamoto, and Ôita - are the most successful economically.

The location of a technopolis was decided by the national government (MITI) after prefectural choices based on inter-prefectural competition and following intense negotiation. The southwestern region of Japan, which has traditionally produced many national politicians, has a large share of technopolises and hosts almost all those built in the early years (1984-5). Kyushu had its own advocates in Hiramatsu Morihiko, the longtime governor of Ôita and former director of MITI, who played a central role in the creation of the Technopolis Plan, and in 
Hosokawa Morihiro, who became governor of Kumamoto in 1983 and prime minister in 1993 (the latter also inspired the so-called Kumamoto Artpolis Project that aims to promote architecture and design in the Kumamoto area). The political and juridical problems of LDP senior leader Kanemaru Shin may explain the stagnation of the Kôfu technopolis that he had spearheaded. Competition for technopolises during this period was as stiff as it had been for the construction of the industrial cities: only 15 industrial cities were chosen in 1962 from 37 candidates, compared with 26 technopolises from 40 candidates in the 1980s.

Local governments intervened in these projects on several levels in addition to promoting their candidates - by giving financial support to industries, offering advantageous loans, and investing heavily in infrastructure. ${ }^{18}$ Their infrastructure budget has been much larger than that of other public investments, such as housing or water purification. In 1990, the public infrastructure (road, water, electricity, and so on) expenditure for technopolises totaled 7 trillion yen, with 930 billion yen going to Shinanogawa, 630 billion to Kôriyama, 370 billion to Kumamoto, and 150 billion to Hamamatsu (Ministry of International Trade and Industry 1997). Local governments were encouraged to provide significant financial support (Cavasin 1996), leading to heavy debt accumulation. The Toyama prefecture even created a special tax to finance its technopolis. The local governments are thus deeply involved in the financing, which has led to heavy debt accumulation. MITI provided only indirect financing. ${ }^{19}$

The results of the Technopolis Plan are so far mixed. Some prefectures went beyond their means and at times the technopolis label was attached to places that did not have any economic and industrial unity (Suzuki 1999). In 1998, when the Technopolis Plan was suspended, the central government shifted responsibility for the sites to the local governments, demonstrating its willingness to permit local control of the planning for the location of industries. This transfer of power has also occurred with research parks (risâchi pâku), small or medium-sized zones in which research and development activities for industries are concentrated (similar to the technopolis concept). In 1995, out of hundreds of such parks, 46 were led by prefectures, 24 by cities, 18 by public agencies (kôdan), and 13 by mixed public-private corporations. In this case, it may be that private industry left the development of these activities to local entities because of the economic downturn. Here again, planning lay first with the national ministries and their think tanks, while local governments were primarily interested in the financing they could obtain by being part of the program. An analysis of Kôriyama in Fukushima-ken has shown that private investment is attracted by short-term factors, such as the presence of infrastructure, a cheap workforce, and land (Kyaw 2001). Long-term factors, such as proximity to the market and provider industries, are less important.

The technological advances made were one determinant that allowed Japan to overcome the shock of the oil crisis in the 1970s. During the following decade, Japan accumulated a commercial surplus and the capital generated led to the realestate and speculative bubble of 1985-90. The rising price of the yen, prompted by the 1985 agreement among the G5 countries (France, the Federal Republic of Germany, Japan, the United Kingdom, and the United States) on a need to adjust 


\section{Hein and Pelletier}

the current exchange rates (Plaza Agreement), precipitated the industrial relocation of Japanese businesses outside the country in order to reduce their export costs while circumventing the quotas for foreign imports adopted by other nations vis-à-vis Japanese products. These economic phenomena translated into a new industrial geography in which Tokyo began to develop as a "global" city, with all that the term implies in regard to urbanization and planning, but which also bears on the megalopolis as a whole and its surroundings. A tendency toward centralization around major urban centers and further population concentration particularly in the Tokyo area, observed since the 1980s, is becoming more and more visible ${ }^{20}$ (Figures 1.2 and 1.3).

\section{Local governments and the redistribution of urban populations}

The vitality of local governments, in terms of economic development and financial power, has been largely dependent on demographics and the number of tax-paying individuals and companies. Urban communities typically contain a large percentage of the Japanese population in a relatively small percentage of the nation's territory. In 2000, cities (shi) accounted for almost 79 percent of the Japanese population - more than 99 million inhabitants out of 127 million on little more than a quarter of the territory (28.4 percent): an urban density of 943 inhabitants per square kilometer. Since the mid-1950s the urban population has surpassed the rural. ${ }^{21}$

The increase in urban populations has gone hand in hand with the demographic exodus from the peripheral prefectures for the past 20 years. ${ }^{22}$ Between 1995 and 2000, 23 of 47 prefectures (ken) in Japan were losing residents. Conversely, prefectures that were part of the Tôkaidô urban axis that reaches from Tokyo via Nagoya to Osaka continued to grow and extend to Kumamoto via Fukuoka in the southwest, and to Sendai via Kôriyama in the northeast. The Tôkaidô urban axis is now home to 90 million inhabitants on 1,300 kilometers and includes parts of 24 prefectures. Most of the Japanese cities are prospering, especially those within the Tôkaidô axis. Decreasing urban population numbers are found only in peripheral cities (with the exception of Kobe in the Osaka area, where the population decrease is connected to the 1995 earthquake). Although the megalopolis as a whole is growing along the Tôkaidô axis, the numbers are not identical. Between 1985 and 2000, Tokyo megalopolis saw a growth of 9.41 percent, Nagoya megalopolis 7.7 percent, and Osaka megalopolis 4 percent. These figures suggest that, within the general pattern of urbanization, concentration is particularly strong in the Tokyo metropolitan area. ${ }^{23}$ The influx of new citizens from the greater Osaka area to Tokyo further highlights this phenomenon.

The growth of the megalopolis is concentrated in the outer areas, confirming the trend toward suburbanization and deconcentration. Tokyo has seen population increases particularly in areas neighboring its administrative boundaries (within its official borders it has maintained a steady population of 11 million since 1970) - in Kanagawa, Saitama, and Chiba prefectures - with a growth of 17.29 percent 


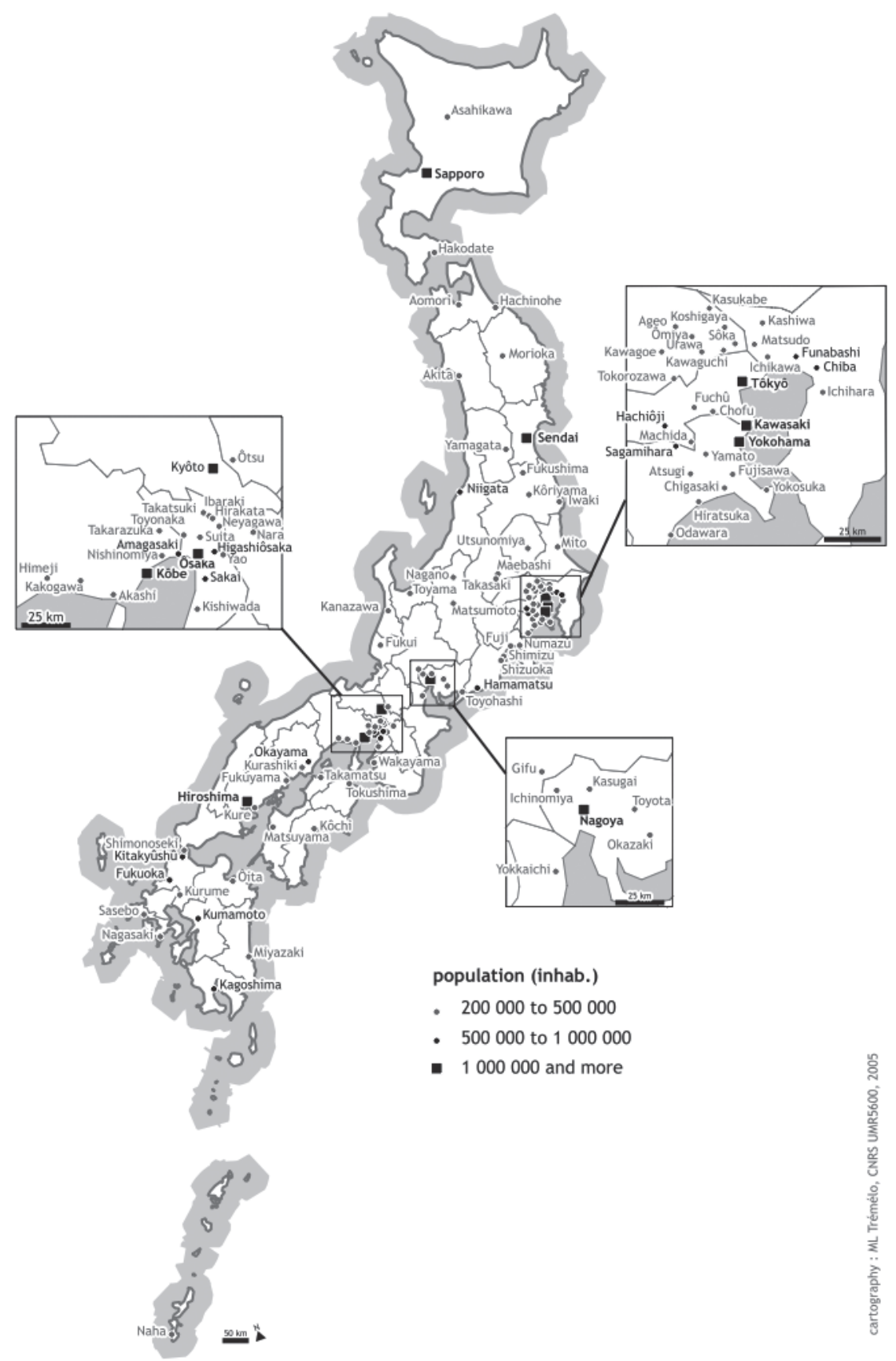

Figure 1.2 The Japanese urban system (2000): cities (shi) with more than 200,000 inhabitants. 




Figure 1.3 Demographic evolution of Japanese cities with more than 100,000 inhabitants, 1980-2000. 
at a distance of between 40 and 50 kilometers from the center. In Osaka and Nagoya, areas somewhat closer to the center are prospering. Meanwhile the inner areas of the major cities are generally losing inhabitants, leading to the so-called "doughnut phenomenon" (dônatsu genshô).

A shift has been occurring in recent years, however, symbolized again by Tokyo and its demographic evolution. Some of the central districts that lost population during the past 20 years - Chiyoda-ku, Minato-ku, and Shibuya-ku in Tokyo, for example, which lost almost 20 percent between 1985 and 1995 - have gained population between 1995 and 2000 (5.6 percent, 3.79 percent, and 3.79 percent, respectively) (Hohn 2002). ${ }^{24}$ This development appears to be based on a restructuring of the relationship between residence and workplace, demonstrated by the decrease in the number of daily commuters from the surrounding areas into Tokyo between 1995 and 2000, from 3.69 to 3.445 million (6.7 percent). The repopulation of central Tokyo is due partly to gentrification, known in Japan by the neologism okushon, ${ }^{25}$ the result of a public and private move to attract a wealthier population to the center, one that has been accompanied by impoverishment in several urban areas

Tokyo thus continues to grow in population and size, a phenomenon that shows no signs of slowing down even while many citizens deplore the gigantism and congestion of the city. The recent spatial plan by the TMG published in April 2001 effectively plans for a capital megalopolis of 33 million inhabitants (Watabe 2002). Because of exorbitant land prices, skyscraper construction for an affluent clientele appears to be the only viable solution.

Together with London and New York, Tokyo is regularly considered one of the three "world" or "global" cities (sekai toshi), as attested to by economic indicators (Sassen 1991). ${ }^{26}$ Tokyo nonetheless differs markedly from other world cities and its status has been questioned in recent years (Saitô and Thornley 2003). Foreign investment, in particular, is not as strong as in its counterpart cities. ${ }^{27}$ In fact, Tokyo is still primarily the Japanese national, political, and industrial capital. The city's role as capital, however, as "state-centered political-bureaucratic" global city, distinguishes Tokyo from New York, a "market-centered bourgeois" global city (Hill and Kim 2000).

\section{Decentralization in Japan: from a national to a global issue}

The relationship between the global, the national, and the local is one of the major geopolitical themes at the beginning of the twenty-first century. Japan is a prime example of this interplay. One of the most important democracies in the world, in spite of its current economic difficulties, it is the second most important international economic power. Its socioeconomic system has been considered a model for the world over the last half century. Japan is also one of the most urbanized countries on the globe, marked by its huge capital, Tokyo - with over 30 million inhabitants, one of the most populated metropolitan areas - and the increasingly urbanized area stretching from Tokyo to Osaka and beyond.

Globalization of the economy leads to a restriction of the role of the national 
governments. The metropolises, and particularly the largest among them, have become the spearheads of economic dynamism while being subject to the variations of international exchanges. Japan, as well as other countries, is faced with contradictory issues: problems related to growth and gigantic cities, the need to face competitors not only inside one nation but globally, the desire for large-scale spatial planning and the absence of appropriate territorial models, the necessity of metropolitan governance and the desire of citizens to control development at the local level. These issues are particularly important in capital cities such as Tokyo, where the central government is present and from where it controls the entire national space, while local forces aim at capturing the benefits of globalization, unwilling to share with the rest of the country represented by the central government.

Japan's economic miracle in the postwar period is reflected in its urban spaces and so is the country's current crisis in almost all areas - economic, political, and socio-cultural. While it may be risky to speculate on the future of this crisis, as a period of passage toward a new uprising or the end of the Japanese miracle, an examination of decentralization policies, spatial restructuring, and the growth of the Japanese city brings to light a paradox that characterizes the country. Japanese urbanization has been criticized for its negative aspects - high density, congestion, pollution, small number of square meters of housing available per person, lack of green spaces, high land prices, and sprawl - and rarely praised for its virtues - efficiency of public transportation, a low crime rate, social vitality. At the same time, over the past 15 years, the possibilities for architectural and urban experimentation have attracted the attention of designers and urban planners interested in community-building. Scholars worldwide examine the effects of globalization in Japan and their local effects and responses, gleaning lessons that have implications for other countries and other cities. With increased globalization, local institutions have become increasingly integrated, or passed over. Urban agents and citizens and their respective actions, as well as the various forms of interaction, differ from one place to another - from the metropolises to large or small cities to neighborhoods - making Japan an excellent case study in the context of local, national, and global relationships.

\section{Notes}

1 On the interaction between Marxism and Japanese nationalism, see Hoston (1986, 1994).

2 In a first step (1868-78), Edo became the Tokyo prefecture (Tôkyô-fu), divided into 15 wards. In a second step (1878-89), the prefecture extended to include the Ogasawara islands, in danger of falling into American hands, and the Izu islands that had been detached from Shizuoka in 1888, as well as the Tama district, detached from Kanagawa prefecture in 1893.

3 The Chinese character to for the Japanese word miyako means "capital."

4 In 1956, five cities were designated Cabinet Ordinance Designated Major Cities (seirei shitei toshi) (Yokohama, Nagoya, Kobe, Kyoto, and Osaka). Since then several cities have been added: Kitakyûshû (1963), Sapporo, Kawasaki, and Fukuoka (1972), 
Hiroshima (1980), Sendai (1989), Chiba (1992), Saitama (2003), Shizuoka (2005). As of April 2006, Sakai will become the fifteenth seirei shitei toshi.

5 In 1978, the city of Yokohama hosted a symposium called "The Era of the Provinces" (chihô no jidai), a name that was reused to characterize all decentralization initiatives. Nagasu Kazuji, then governor of Kanagawa prefecture, of which Yokohama is the main city, requested that the central government let local entities manage environmental and urban issues. The best-selling novel Kirikirijin (The people of Kirikiri) by Inoue Hisashi, published in 1981, reflected the dissatisfaction of the Japanese citizens with the central government.

6 While it is possible to statistically calculate specifically determined areas, such as the Densely Inhabited Districts (DID) (jinkô shûch $\hat{u}$ chiku) - defined by the Japanese national statistics bureau as urban spaces with a density of more than 4,000 inhabitants per square kilometer in communities with over 5,000 citizens - the fluidity of the megalopolis, which is marked by processes of expansion and compression, and the difficulties that the Japanese themselves have in distinguishing between urban and rural spaces, present challenges.

7 See Pelletier (1997: 163-6; 2001: 117-18).

8 Following the findings of the Shoup Mission, the Japanese government established the Kanbe Committee (named after its chairman, Kanbe Masao) to investigate local administration.

9 On the Marxist support for Japan's pan-Asian policies see also Maîtron and Shiota (1979).

10 Of the 16 successive prime ministers in the 42 years following World War II, until the arrival of Nakasone Yasuhiro (1982-7), only two (Tanaka Kakuei and Suzuki Zenkô) had not been politically active before 1945. Furthermore, the gray eminences of the LDP were all politically implicated in the prewar militarism. This situation is very different from that of postwar Germany, where de-Nazification was more widespread (Yoneyama 1999).

See Seagrave and Seagrave (2002) and Thomann (1995) for a discussion of career continuities in Japan for prominent figures including Kishi Nobusuke (1896-1987), who, detained as a war criminal of the highest category (A), became prime minister in 1956, and Yoshida Shigeru (1878-1967), who became prime minister five times (1947, 1948, 1949-52, and 1952-3).

On issues of continuity in planning, see Hein 2003b.

11 The creation of national agencies (kôdan) between 1950 and 1960 responsible for housing and highway development, among other fields, took planning tools away from the local governments (see MacDougall 1983).

12 Land readjustment was promoted by Ishikawa Hideaki (1893-1955), a key figure in the transition from the pre- to the postwar period. An iconic planner of the 1940s, he directed the urban planning bureau in Tokyo during and after the war (see Ishida 1987).

13 For an analysis of the politics of high technology see also Bass (1998) and Yamazaki (1992).

14 Among the companies that moved to cities in Kyushu are Mitsubishi, to Kumamoto in 1967; the US company Texas Instruments, to Ôita in 1968: NEC (Nippon Electric Company), to Kumamoto in 1969; and Kyocera, to Kagoshima in 1969 and to Oki in 1970.

15 The five major software companies are located primarily in three megalopolises and the four provincial metropolises of Sapporo, Sendai, Hiroshima, and Fukuoka (see Kitagawa 1996).

The geographical pattern of the plastic-mold manufacturing sector shows even more discernible tendencies, with a clear division of work between the headquarters, situated in the industry's birthplace in the Jônan district in southern Tokyo, and the neighboring area of Kawasaki-Yokohama (see Oda 1997). 
The automobile industry, beyond its enormous investments abroad, has redistributed itself on the Japanese archipelago over the last 20 years, opening new assembly sites close to its original headquarters and expanding its sphere of sub-tiers in the Tokyo metropolis (see Flüchter and Yamamoto (2002), Miyakawa (1999), and Ogawa (1995)).

16 For example, the city of Nagaoka (Niigata-ken), following a visit by the city's mayor to the new Finnish city of Tapiola, in 1971, launched a technopolis project, later known as Shinanogawa Technopolis. Kuniko Fujita states, "Nagaoka city had started Nagaoka New Town project long before the State had announced its Technopolis Plan. ... When MITI started the technopolis project, it invited Nagaoka New Town Project to join" (Fujita 1990: 244).

17 According to sociologist Tessa Morris-Suzuki, politicians and media consider the Technopolis Plan the result of the combination of the forces of city and local authorities, industry, and national government that was typical of the kaizôron (MorrisSuzuki 1990). The plan privileged rural and partly rural areas, often with a polycentric arrangement in a "green" environment. In addition, it constituted a means by which the economic and technological development of a region close to an existing city could occur. Finally, it allowed citizens to adopt a new concept of urbanity, including new lifestyles and new services.

18 The Yamanashi Prefecture thus offered 10 million yen and other incentives to four enterprises to encourage them to locate in the Kôfu technopolis (see Bass 1998: 395).

19 Estimates of MITI's financial participation vary. Amy Glasmeier states that the national budget allocated to the Technopolis Plan in the early years was only a modest equivalent to 10 million dollars (Glasmeier 1988). Fujita, however, states that the budget was 1.485 billion yen in 1985, one-third for the relocation of industry (Fujita 1990). Steven Bass finds that the role of MITI is largely indirect (Bass 1998: 394-5).

20 David Edgington opines that service industries will most likely cluster in Tokyo, Osaka, and Nagoya (Edgington 1997).

This tendency was already apparent in the 1980s. Murata Kiyoshi points out that Tokyo remains the mother technopolis of Japan, dictating its growth toward peripheral regions (Murata 1988).

21 Although the delimitation of urban areas is often not very precise, the concentration of DIDs was 65.2 percent of the Japanese population in 2000, a little over 81 million inhabitants on less than 3 percent of the territory.

22 This phenomenon is not identical with what occurred during the rapid growth period, as the redistribution between departments as well as within the metropolises was much higher (Morikawa 1998).

23 According to standard Japanese classifications, the metropolitan area of Tokyo (Tôkyô daitoshi-ken) is composed of four departments: Tokyo, Kanagawa, Saitama, and Chiba. The capital area (shuto-ken) includes four more departments: Ibaraki, Yamanashi, Gunma, and Tochigi. This entity comprises 41 million inhabitants (one-third of the Japanese population) on 34,428 square kilometers, with an average density of 1,111 inhabitants per square kilometer.

24 Partial results of the 2005 national census confirm this trend.

25 Okushon is a play on other Japanese words. The term manshon comes from the English "mansion" and characterizes high-end residential housing (or something that aspires to be so). Man means 10,000 in Japanese, oku 100 million. Okushon thus alludes to the manshon whose prices have exploded.

26 Economic indicators, such as the growth of financial markets following deregulation in the 1980s, the number of transnational headquarters, and growth in high-level services underscore Tokyo's membership in the group of world cities (Machimura 1994). During the bubble period, Tokyo was the center of information technologies and was home to 80 percent of foreign headquarters, 73 percent of foreign banks, 55 percent of all headquarters for Japanese companies worth more than 5 billion yen, and one-quarter of all Japanese university students. 
27 In contrast to London, New York, Singapore, and Hong Kong, the share of foreign exchange markets decreased between 1989 and 1995 (Yoshikawa 1998).

\section{References}

Abe Hitoshi and Yorimoto Katsumi (eds.) (1988) Chihôjichi no gendai yôgo (Contemporary glossary of local governments), Tokyo: Gakuyô shobô.

Ansart, Olivier (1995) "Centralisation et collectivités locales au Japon," Hérodote 78-9: 240-9.

Bass, Steven J. (1998) “Japanese Research Parks: National Policy and Local Development," Regional Studies 32(5): 391-403.

Berque, Augustin (ed.) (1993) Du geste à la cité, formes urbaines et lien social au Japon, Paris: Gallimard.

- (1994) La maîtrise de la ville, urbanité française, urbanité nippone, Paris: Ecole des Hautes Etudes en Sciences Sociales.

Cavasin, Nathalie (1996) "Science, économie, territoire: les cités scientifiques et les technopôles au Japon," unpublished thesis, Université de Toulouse-Le Mirail.

DeWit, Andrew (1998) "Heisei Japan's Growth Industry: The New Decentralization Debate," Social Science Japan Journal 1(1): 141-6.

Dower, John W. (1999) Embracing Defeat. Japan in the Wake of World War II, New York: W. W. Norton \& Company/The New Press.

Edgington, David W. (1994) "The Geography of Endaka: Industrial Transformation and Regional Employment Changes in Japan, 1986-1991," Regional Studies 28(5): 52135.

- (1997) "The Rise of the Yen, 'Hollowing out' and Japan's Troubled Industries," in Raymond F. Watters and Terry G. McGee (eds.) New Geographies of the Pacific Rim, London: Hurst \& Co., pp. 170-89.

Flüchter, Winfried and Yamamoto Kenji (2002) "Automobilindustrie in Japan," Geographische Rundschau 54(6): 18-26.

Fujita Kuniko (1990) “The Technopolis: High Technology and Regional Development in Japan," in Guy Jalabert and Christiane Thouzellier (eds.) Villes et technopoles Nouvelle urbanisation, nouvelle industrialisation, Toulouse: Presses Universitaires du Mirail, pp. 231-50.

Fukashi Horie (1996) "Intergovernmental Relations in Japan: Historical and Legal Patterns of Power Distribution between Central and Local Governments," in Jong S. Jun and Deil S. Wright (eds.) Globalization and Decentralization: Institutional Contexts, Policy Issues and Intergovernmental Relations in Japan and the United States, Washington DC: Georgetown University Press.

Gao, Bai (1994) “Arisawa Hiromi and his Theory for a Managed Economy," Journal of Japanese Studies 20(1): 115-54.

Glasmeier, Amy (1988) "The Japanese Technopolis Program: High Technology Development Strategy or Industrial Policy in Disguise?" International Journal of Urban and Regional Research 12: 268-83.

Hagihara Kyôko (1998) "Les relations entre l'Etat et les collectivités locales," Daruma 3: 83-99.

Hein, Carola (2003a) "Change and Continuity in Postwar Urban Japan," in Carola Hein, Jeffry M. Diefendorf, and Ishida Yorifusa (eds.) Rebuilding Urban Japan after 1945, New York: Palgrave Macmillan, pp. 236-49. 


\section{Hein and Pelletier}

Hein, Carola (2003b) "Visionary Plans and Planners," in Nicolas Fiévé and Paul Waley (eds.) Japanese Capitals in Historical Perspective, London: RoutledgeCurzon, pp. 309-46.

Hein, Carola, Diefendorf, Jeffry M., and Ishida Yorifusa (eds.) (2003) Rebuilding Urban Japan after 1945, New York: Palgrave Macmillan.

Hein, Laura E. (1994) "In Search of Peace and Democracy: Japanese Economic Debate in Political Context," Journal of Asian Studies 53(3): 752-78.

Hill, Richard Child and Fujita Kuniko (2000) "State Restructuring and Local Power in Japan," Urban Studies 37(4): 673-90.

Hill, Richard Child and Kim, June Woo (2000) "Global Cities and Developmental States: New York, Tokyo and Seoul," Urban Studies 37(12): 2167-95.

Hohn, Uta (2002) "Renaissance innerstädtischen Wohnens in Tôkyô - Trend zur Reurbanisierung," Geographische Rundschau 54(6): 4-11.

Hoston, Germaine A. (1986) Marxism and the Crisis of Development in Prewar Japan, Princeton, NJ: Princeton University Press.

- (1994) The State, Identity, and the National Question in China and Japan, Princeton, NJ: Princeton University Press.

Ide Sakuo and Takeuchi Atsuhiko (1980) "Jiba sangyô: Localized Industry," in Association of Japanese Geographers (ed.), Geography of Japan, Tokyo: Teikoku-shôin, pp. 299319.

Ishida Yorifusa (1987) Nihon kindai toshi keikaku no hyakunen (A hundred years of Japanese urban planning), Tokyo: Jichitai Kenkyûsha.

Jain, Purnendra (1999) “Japan's 1999 Unified Local Elections: Electing Tôkyô's Governor," Japanese Studies 19(2): 117-32.

Kashima Hiroshi (1995) "Keihin chiiki gaienbu ni okeru ôte denki mêkâ no renkan kôzô T-sha Ôme kôgyô no gaishû riyô wo jiretsu toshite" (Subcontract linkages of a large electronics enterprise in the fringe of the Keihin area: an empirical study of the Ôme plant of company T), Chirigaku Hyôron 68-A(7): 423-46.

Kitagawa Hirofumi (1994) "The Development and Functional Change of a Multi-locational Corporation's Plants in the Electrical Machinery Industry," Geographical Review of Japan 67-A(12): 858-81.

_ (1996) "Waga kuni jûyô konpyûta mêkâ ni okeru sofuto wea hausu no tenkai" (The development of large corporations' software houses in Japan), Jimbun chiri 48(5): 500-15.

Kyaw, Aung (2001) "Decentralization of Production and the Formation of Technology Regions: A Case Study of the Kôriyama Technopolis," Geographical Review of Japan 74-B(2): 199-211.

MacDougall, Terry Edward (1983) "Local government," in Kôdansha Encyclopedia of Japan, Tokyo: Kôdansha, 5: 65-71.

Machimura Takashi (1994) Sekai toshi Tôkyô no kôzô tenkan (Restructuring of the global city Tokyo), Tokyo: Tôkyô Daigaku Shuppankai.

Maîtron, Jean and Shiota Shôbei (eds.) (1979) Dictionnaire biographique du mouvement ouvrier international - le Japon. Paris: Les Editions ouvrières.

Matsui Konomu (1998) "La gestion de la recherche-développement," in Yoshikawa Hiroyuki (ed.) Made in Japan - L'industrie japonaise au tournant du siècle, Paris: Le Livre de poche, pp. 91-109.

Ministry of International Trade and Industry (MITI) (1997) Tekunopolisu kaihatsu shishin no henkô ni tsuite (Guideline for change in the Technopolis Plan), Tokyo: MITI.

Miyakawa Yasuo (1999) "Mutation of the Japanese Industrial Orbit in the Global Economy," Geographical Review of Japan 72-B(2): 75-99. 
Morikawa Hiroshi (1998) Nihon no toshika to toshi shisutemu (Urbanization and the urban system in Japan), Tokyo: Kokon shoin.

Morris-Suzuki, Tessa (1990) "Technopolises, Teletopias and Multifunction Policies: Japanese Regional Planning in the Information Age", in Henry Bakis (ed.) Communications et territoires, Paris: La Documentation Française, pp. 269-80.

Murata Kiyoshi (1988) "The Technopolis: Concept and Present Situation," Journal of Economics 29: 39-51.

Namikawa Shimio (ed.) (1996) Bunken shakai no sôzô: kokka shuken daha eno shinario (Creating a decentralized society: breaking free of the centralized state), Tokyo: Tôkyô keizai shinpôsha.

Norman, Herbert (1975) Origins of the Modern Japanese State, in John W. Dower (ed.), New York: Pantheon Books.

Numata Ryô (1996) Chihô bunken kaikaku: shimin no seifu wo sekkei suru (Plans for regional decentralization: creating a government of citizens), Tokyo: Kôjinsha.

Oda Hironobu (1997) "The Locational Dynamics of the Japanese Plastic-Mold Manufacturing Industry during the Microelectronics Innovation," Geographical Review of Japan 70-B(1): 10-30.

Ogawa Yoshiko (1995) "Nissan-gata buhin mêkâ no ritchi tenkai to seisan kôzô" (The spatial organization of Nissan's parts suppliers in Japan), Jimbun chiri 47(4): 334.

Pelletier, Philippe (1997) "La politique régionale," in Le Japon, Paris: Armand Colin, pp. $163-6$.

—-(2001) “La capitale du Japon, un déménagement difficile," L'Information géographique 65: $97-124$.

Saitô Asato and Thornley, Andy (2003) "Shifts in Tôkyô's World City Status and the Urban Planning Response," Urban Studies 40(4): 665-85.

Sassen, Saskia (1991) The Global City: New York, London, Tokyo. Princeton, NJ: Princeton University Press.

Seagrave, Sterling and Seagrave, Peggy (2002) Opération "Lys d'or" - Le scandaleux secret de la guerre du Pacifique ou comment les Etats-Unis ont utilisé le trésor de guerre japonais pour financer la guerre froide, Paris: Michalon.

Shigemori Akira (1998) "Chihô bunken to zei zaigen mondai" (The problem of tax revenues and financial resources in decentralization), in Chiho bunken no yugami (The strain of decentralization), Tokyo: Jichitai kenkyûsha, pp. 34-41.

Shimada Haruo (1998) "Les industries des semi-conducteurs, du matériel informatique, des logiciels et des équipements de télécommunications," in Yoshikawa Hiroyuki (ed.) Made in Japan - L'industrie japonaise au tournant du siècle, Paris: Le Livre de poche, pp. 267-304.

Suzuki Shigeo (1999) "Chihô kôgyô toshi no naihatsugata kaihatsu to chihôzaisei" (The endogenous development of industrial regional cities and local finances), Nihon chihô zaisei gakkai, dainanakai zenkoku taikai hôkoku yôshi 29(60): 99-102.

Takeuchi Atsuhiko (1993) "Location Dynamics of the Japanese Semiconductor Industry in the Rapid Technological Innovation," Geographical Review of Japan 66-B(2): 91104.

Takeuchi Atsuhiko and Mori Hideo (2001) "The Sustainable Renovation of the Industrial Complex in Inner Tôkyô: A Core of the Japanese Machinery Industry," Geographical Review of Japan 74-B(1): 33-46.

Thomann, Bernard (1995) “Confrontation, coopération et fusion: les intérêts des travailleurs, des industriels et de l'Etat dans la formation des relations du travail au Japon et en France jusqu'en 1945," Ritsumeikan gengo bunka kenkyû 7(1): 137-74. 


\section{Hein and Pelletier}

Watabe Tatsurô (2002) “'Shutoken megaroporisu kôsô' to 'Shutoken kihon keikaku'” (The 'Capital megalopolis concept' and the 'Comprehensive capital plan'), Toshi mondai 93(11): 37-50.

van Wolferen, Karel (1989) The Enigma of Japanese Power, New York: Vintage Books.

Yamazaki Akira (1992) Nettowâku kugata haichi to bunsan seisaku (Regional network model and decentralization policy), Tokyo: Taimeidô.

Yoneyama, Lisa (1999) Hiroshima Traces: Time, Space, and the Dialectics of Memory, Berkeley, CA: University of California Press.

Yoshikawa Hiroyuki (ed.) (1998) Made in Japan - L'industrie japonaise au tournant du siècle, Paris: Le Livre de poche. 


\title{
2 Local initiatives and the decentralization of planning power in Japan
}

\author{
Ishida Yorifusa
}

Modern urban planning systems in the United States, Great Britain, Germany, Scandinavia, and other European countries follow a decentralized model in which local governments hold general planning authority. In Japan, although the system of modern city planning has learned much from the experiences of these countries, it has been institutionalized as a centralized system for more than half a century.

Only in 1968, with the enactment of the City Planning Law (shin toshi keikaku $h \hat{o}$ ), was the first step taken toward transferring power from central government to local administrations. Over the next 30 years, citizen participation in planning decisions increased and local planning authorities gained power. The next step, one that is imminent, both in the field of city planning and in local governance, is the decentralization of public administration under a set of laws. The relationship between local activity and decentralization - the focus of this discussion - is one of the key current issues of Japan's urban policy.

There is some concern, however, as to how far decentralization will actually extend. Some critics of the new City Planning Law, which was amended by the Omnibus Law for Decentralization of Powers (chihô bunken ikkatsu hô), effective April 1, 2000, have taken it to task for falling short of true decentralization. Others believe that local governments and communities lack the means to make the most of the laws available.

Before attempting an analysis of decentralization and citizen participation in urban planning as an integral part of contemporary history, it is useful to review briefly the development of city planning in Japan prior to 1968, especially as relates to local control, and to determine what can be learned from the past.

\section{Urban and regional policies in the Meiji period: modernization and centralization in Japan}

\section{Local initiatives in city planning before the enactment of the Tokyo Urban Area Improvement Ordinance (Tôkyô shiku kaisei jôrei)}

During the period of chaos that followed the1868 Meiji Restoration, urban issues were addressed by individual cities rather than by the central government, which was occupied with other matters. Traditional town planning methods, such as the request for construction of fireproof buildings along wide roads (hirokôji nurigome 
zukuri) to prevent the spread of fires, were common - even in the new capital of Tokyo. An exception was the construction of a red brick mall along Ginza Street initiated by the central government in 1872 (Fujimori 1982: 1-44). Examples of the use of planning tools during the Edo era include the creation of open space for fire evacuation in Akihabara in 1869; the 1874 ordinance restricting building on rights of way to facilitate the extension of roads (Ishida 1987: 127-38); and the 1881 improvement project in Kanda Hashimoto-chô (Ishida 1987: 69-125). For the 1881 project, the money was raised using a "7 percent deposit for the poor" (shichibu tsumi kin) collected by the council of townsmen (machi kaisho). ${ }^{1}$ The townspeople used the deposit to buy and manage land and houses.

Other cities carried out their own city planning projects and developed planning systems to meet the needs of modern (Meiji) Japan, including the construction of districts for local government offices; the expansion of built-up areas; the construction of railways; and the improvement of congested areas and of procedures for civil disaster preparedness and recovery. Among notable examples of city planning are the following: the Sapporo urban development project undertaken by the Hokkaido Colonization Office in 1871; the Sakaechô-dôri road expansion project in Kobe carried out by the Hyogo prefectural government in 1873; a plan for a local government office district in Yamagata proposed by Governor Mishima Michitsune in 1876; a recovery and block readjustment project in Hakodate following a major fire in 1878-9; and a project to expand major roads directed by the Kyoto prefectural government in 1882.

These projects met the needs of each city, and often employed unique methods of implementation and financing. The 1873 road expansion project in Kobe, for example, used a method whereby land along the 20-m-wide road was expropriated (excess condemnation) and sold at market prices after the completion of the project to pay for it (Tsubohara 1995: 37-8). Among the city planning systems created during this period were Osaka prefecture's Ordinance for Road Boundaries (dôro keikai rei) of 1871, which required all existing buildings or parts of buildings that jutted out beyond building lines (supposed to be the original street boundaries) $)^{2}$ to be demolished and brought back to the original building lines; and an attempt by Kyoto prefecture to expand roads through an ordinance requiring a two-meter setback from existing road boundaries in 1872 (Ishida 1987: 138-67). Regulations on row-house construction (nagaya kenchiku kisoku) in several prefectures, including Osaka and Kanagawa, went into effect circa 1886. Although these regulations were imposed almost unanimously in the majority of cities as a result of the campaign conducted by the Home Ministry's (Naimushô) Sanitation Bureau (eisei kyoku) and its auxiliary organ, the Japan Public Sanitation Association (Dai Nippon shiritsu eisei Kyôkai), they differed from city to city (Tanaka 1991: 87-165), and maintained a local character until the passage of the Urban Building Law (shigaichi kenchiku butsu hô) in 1919.

\section{The debate on decentralization and the Tokyo Urban Area Improvement Projects}

From 1888 to 1918 , the central government carried out the Tokyo Urban Improvement Projects (shiku kaisei jigyô) intended to improve the capital. The 
system and framework for what was the first rebuilding plan to take place in modern Japan was provided by the Tokyo Urban Area Improvement Ordinance, enacted by decree of the emperor; Tokyo prefecture, and later the city of Tokyo, implemented and financed the project. The plan for urban improvement and projects to be implemented every fiscal year, however, was discussed and established by the Tokyo Urban Area Improvement Committee (Tôkyô shiku kaisei iinkai) within the Home Ministry, and approved by the cabinet after reporting to the home minister (Naimu daijin). Clearly this was a national project. This centralized system lived on in the 1919 City Planning Law (1919 nen (or kyû) toshi keikaku $h \hat{o}$ ), which gave rise to the centralized nature of Japan's city planning that would exist for a period of 50 years, until 1968.

Probably the first instance in which the issue of decentralization in relation to Japanese city planning was raised was in the discussions surrounding the makeup of the Tokyo Urban Area Improvement Committee. While many approved of the committee's inclusion of popularly elected members as a step toward selfgovernance, many others argued that the composition of the membership was problematic. The ensuing debate was captured in a newspaper report of the time: "On September 1, 1888, the Sectional Meeting by Members from wards (kubukai) of the Tokyo Prefectural Assembly (Tôkyô-fukai) held an election among its members for 10 of them to be sent to the Tokyo Urban Area Improvement Committee. ${ }^{3}$ The question was raised that this number of 10 was much too small, compared with the allocation of 15 members from the central government (selected among higher-ranking officials), from the standpoint of local governance" (Yomiuri, September 2, 1888). In the meantime the Tokyo Association of Commerce and Industry (Tôkyô shôkôkai) requested that the central government include its representatives among the committee members. Newspaper editorials were split over this issue. One editorial supported the idea, recommending that the balance of central government to local members be maintained by adding five members from the Tokyo Association of Commerce and Industry. Others demanded that meetings of the committee be open to the public. The central government, in any event, did not accede to calls to increase the number of publicly elected members.

The issue of control over the committee by representatives of the central government had an enduring impact. In February 1893 the Tokyo City Assembly (Tôkyô-shi gikai) proposed to the central government that the assembly be responsible for the planning of Tokyo's improvement. The assembly's argument was that it was unfair that the committee should determine Urban Area Improvement plans for projects funded entirely by Tokyo when two-thirds of its members were central government officials (Tôkyô-to Zaisei-shi Kenkyû-kai 1969: 345).

\section{Local city planning in the late Meiji period}

Unlike the situation in the capital, in which the central government tried to take the initiative in promoting its improvement plans, planning in the regional cities was conducted largely by the voluntary efforts of local governments. Compared with Tokyo's plans, which focused on the improvement of built-up areas, plans in other cities confronted two different issues: the new fact of urban expansion; and the participation (and, in some cases, leadership) of landowners and private 
companies. Among such local efforts, noteworthy cases were the improvement (shigaichi seibi) of Kobe through land-readjustment projects carried out by the landowners' association (1890); an agreement on the development of new urban areas in the town of Washo-machi (currently in the city of Kure) in Hiroshima prefecture (1898); a development plan for new urban areas in Osaka, prepared at the request of Osaka city (also 1898); the cleaning up of a burned area and the installation of a fire protection belt after a major fire in Takaoka city, in Toyama prefecture; a report on a civil engineering survey prepared by a committee for the survey, arranged by the Kyoto City Assembly (Kyôto shigikai) (1899); the demolition of parts of buildings infringing on rights of way in Osaka city during the construction of streetcar routes (since1903); three major projects (including road extension) in Kyoto city (since 1907); and the repair of areas affected by major fires in southern Osaka (1909) and northern Osaka (1912).

The new urban area improvement in Kobe took place seven years before the enactment of a law on land readjustment, "on improvement of land plots" (tochi kukaku kairyô ni kansuru ken), by the central government in 1897, and can be seen as a local initiative that paved the way toward the creation of a planning system legally formalized by the central government (Tsubohara 1995: 75-108; Ohara 2002: 25-38, 165-193). The case of Washo-machi involved a land-readjustment agreement among landowners with the participation of the town hall (machi yakuba), which detailed project expenses to be borne by the landowners (City of Kure 1924: 38-51).

Osaka's development plan of 1898, prepared by Yamaguchi Hanroku, who had studied city planning in France, could be called Japan's first urban master plan for the entire city area. During this period, the issues of urban expansion and industrial location were more pressing in Osaka than in Tokyo (Nishikawa, Fujimoto, and Mutô 1989: 316).

From the turn of the century onward, more comprehensive building controls, rather than the mere regulation of row-houses and other specific types of buildings, emerged in many parts of the country. In 1909, Osaka prefecture established Building Control Regulations (Ôsaka-fu kenchiku torishimari kisoku). The city of Tokyo commissioned the Architectural Institute of Japan (Nihon Kenchiku Gakkai) to draft the Tokyo City Building Ordinance (Tôkyô-shi kenchiku jôrei) in 1906, with a final draft submitted in 1913. This ordinance was not put into effect, however. At this time, it was still presumed that each local government would enact its own regulations, tailored to local requirements. Although Osaka's regulations were criticized for setting a far too lax standard, they reflected the land-use conditions in that city and were realistic and applicable tools.

\section{Structure of the prewar city planning laws and the completion of centralized city planning}

The Tokyo Urban Area Improvement Project (shiku kaisei jigyô), Japan's first modern city planning effort, initiated by the central government in 1888, spanned 30 years. Its importance is reflected by the fact that in 1988 the City Planning 
Institute of Japan (Nihon Toshi keikaku Gakkai), the Ministry of Construction (Kensetsushô), and the Tokyo Metropolitan Government, or TMG (Tôkyô-to), held commemorative events celebrating the Centennial of Japanese City Planning.

While the central government focused on improving built-up areas in the capital under the aegis of this national initiative, other cities faced the new issue of urban growth. During the period between 1891 and 1920, the number of cities having populations between 50,000 and 100,000 increased from 12 to 31; and those with more than 100,000 from six to 16 . Most of these cities were dedicated to industrial, port, mining, or military functions, and developed in response to the industrial and military buildup of the nation. Urbanization and industrialization rapidly progressed in regional cities. As a result, a new type of city planning was much more necessary in these cities than in Tokyo.

The City Planning Law and the Urban Area Buildings Law (shigaichi kenchikubutsu hô) of 1919 are credited as being the first modern city planning systems applicable to all Japanese cities. It could also be argued that these were a highhanded attempt by the national government to centralize Japan's city planning system at the expense of local planning initiatives and building controls that had been put in place during the late nineteenth to the early twentieth century. These early local achievements merit some examination.

\section{Seki Hajime and Osaka: local initiatives}

Around the turn of the twentieth century, city planning efforts undertaken by local authorities shifted from project-specific to more general and comprehensive in nature. Local governments began to use new methods and tools, including performing general surveys of urban issues, planning, and project implementation. In Kyoto, for example, a temporary committee for the purpose of producing a survey of public works (rinji doboku chôsa iinkai) was established in 1899 . It compiled an advisory report on civil engineering that included plans for the expansion of the city area as well as of the water supply and roads. Based on this report, the city of Kyoto launched a project to extend 11 routes (mainly roads used by streetcars) in 1907. This became known as one of Kyoto's "Big Three" projects (sandai jigyô). Following Kyoto's example, Nagoya (1911) and Kobe (1914) initiated surveys for urban improvement. Had the central government supported these local efforts both financially and institutionally, a decentralized and locally specific city planning system might well have developed in Japan.

The most notable of these initiatives took shape in Osaka. In 1917, the city of Osaka established a committee on urban improvement (toshi kairyô chôsa-kai), which in January 1918 compiled a draft of the Osaka Urban Area Improvement Law (Ôsaka shigai kairyô hô sôan) to enforce a completely new city planning system for the city of Osaka and its environs. The committee also started a campaign to request that the central government enact the draft into national law. The historian Watanabe Shun-ichi has regarded this draft as the missing link between the Tokyo Urban Area Improvement Ordinance and the 1919 City Planning Law (Watanabe 1987) and reprinted the draft in his book (Watanabe 1993: 261-2). In 
some respects, the draft was much more innovative than the system that would be instituted by the 1919 City Planning Law. For example, one of the draft's provisions on land-readjustment projects (kukakuseiri jigyô) was similar to the method introduced in the 1919 City Planning Law, which followed the agricultural landreadjustment system (kôchiseiri seido). But the draft's method was based on planning tools already in use in Osaka and Kobe and was far more sophisticated and practical than the 1919 City Planning Law's system. ${ }^{4}$

The key figure on the committee was Seki Hajime, then the deputy mayor of Osaka and later its mayor. ${ }^{5}$ A former professor at the Tokyo Higher Commercial School (Tôkyô kotô shôgyô gakkô) who had studied in the Netherlands and was familiar with European city planning, Seki did not attempt to merely copy European experiences, but tried to reflect Osaka's particular local conditions in city planning.

Seki did not consider the idea that city planning be kept in the hands of local government. Article 1 of the draft stipulates that the authority "to design and to decide projects to be implemented every year" should be given to the "Osaka Urban Area Improvement Committee"(Ốsaka shigai kairyô iinkai), to be supervised by the home minister. This contrasts with the demand made by the Tokyo City Assembly in 1893 that the central government give city planning power to the assembly. Article 12 of the draft granted the authority to permit land readjustment by the landowners' association to the home minister rather than to the mayor of Osaka. This may be further evidence that Seki considered city planning to be a national issue.

The draft proposed giving authority over a number of issues to either the city of Osaka or its mayor: financing the cost of urban improvement projects (Article 3); appointing the executor of urban improvement projects (Article 4); levying taxes on profits from the increased land value (tochi zôka zei), surtaxes (fuka-zei) on local taxes, and betterment levies (juekisha futankin) (Article 5); conducting land readjustments for joint executors at their request (Article 12 section 4); and establishing an ordinance concerning "restrictions on buildings and land use" (Article 18). The only article in the draft related to local government involvement in city planning authority is the last, which concerns an ordinance that also required a decision by the Osaka Urban Area Improvement Committee under the auspices of the Home Ministry, and final approval by the home minister.

It seems that Seki was more concerned with the financing of projects than with the decentralization of city planning. Thus, when the Home Ministry promised to apply the Tokyo Urban Area Improvement Ordinance (which stipulated the central government's financial support for city planning projects) to Osaka and other cities, and enact the City Planning Law early, he was quick to abandon Osaka's plan and approve the Ministry's offer. Other cities also called for the involvement of the national government in city planning - in the expectation of financial support. Monetary considerations thus prevailed over local governance and local initiatives. In the years following the enactment of the 1919 City Planning Law, Seki again expressed a strong wish to levy taxes on gains from increased land value. 


\section{The debate on financing city planning}

The 1919 City Planning Law and the Urban Area Buildings Law laid the foundation for national and centralized city planning in Japan. Of all the discussions and debates to occur in the City Planning Research Committee (toshi keikaku chôsa iinkai), established within the Home Ministry, the most controversial was how to finance city planning (Akagi 1968: 522-33). ${ }^{6}$

Sources of revenue included those specified in the Tokyo Urban Area Improvement Ordinance, subsidies, taxes on land value increases (tochi zôka zei), betterment levies imposed on those benefiting from planning projects, and taxes on unutilized urban land (kanchi zei). The argument was between the vice minister for finance, Jino Katsunosuke, who opposed any sources of revenue other than those listed in the Ordinance, and the many other members of the committee who supported the new sources of revenue.

Consequently, the subsidy was not specified in the City Planning Law. The introduction of taxes on land value increases or on unutilized urban land, which local governments hoped would be formalized, was postponed. These taxes were intended to be institutionalized by imperial decree (chokurei), but their planning took too long and the draft was turned down by the House of Peers, which counted many of the propertied classes among its members (Sumisaki, Kobayashi, and Ôba 1981).

One new revenue source - the betterment levy - was institutionalized, and became an important revenue source for the construction and widening of roads in regional cities (Tôkyô Shisei Chôsakai 1929). In most cases (there were slight regional variations), owners of roadside land were charged a certain portion of project expenses (typically one-third). These landowners strongly opposed the levy and called on the government to clarify the meaning of "betterment" and whether they would actually benefit from the development. As a benchmark of the benefit, the landowners demanded that a land evaluation be made. The government tried to avoid introducing the land-evaluation system and used vague terms such as "tangible and intangible benefits." The landowners were not convinced by this finagling and the system of betterment levies could not be developed in a positive way satisfactory to both sides (Ishida and Furusato 1980). ${ }^{7}$

The Home Ministry's Ordinance (Naimushô rei) no. 17 of 1922 on the betterment levy in Osaka was a special case, including provisions for the appointment of appraisers and land evaluation after completion of the project to adjust the amount of the payment. Apparently, it was Seki Hajime who initiated the introduction of the system of benefit reevaluation. In 1922, Seki invited to Osaka the American historian Charles A. Beard, who was an adviser to Tokyo's mayor, Gotô Shinpei, and asked him to give a lecture on the betterment levy (Beard 1923: 92-111). ${ }^{8}$ In his lecture, Beard emphasized the importance of land evaluation in the American betterment levy system. Without having conducted a single case of land evaluation, the peculiar system in Osaka was eliminated when Osaka's ordinance was amended in 1933 (Ishida and Furusato 1980).

Another new planning concept, which Seki recommended in his article and which was codified in the 1919 City Planning Law, called for using develop- 


\section{Ishida}

ment profits for city planning projects (Seki 1917). The "excess condemnation" or "zone expropriation" (chôka shûyô or chitai shûyô) method, with "land readjustment for site improvement along streets" (kenchiku shikichi zôsei kukakuseiri), should have been used to redevelop built-up areas. But in all the years until 1954, when it was abolished, this idea was applied in just three projects nationwide. The only example in which a development project created profits that were used as a revenue source was one to develop a station plaza on the west side of Shinjuku Station in the 1930s (Koshizawa 1991: 76-87; Suzuki 1991).

One advocate of the decentralization of city planning in the early twentieth century was Miyake Iwao, an Osaka journalist who later became a member of the House of Representatives (shûgiin giin). In his 1908 book on urban issues, he discussed ways to finance urban improvements and made some important suggestions for specific revenue sources, including a tax on land value increases and income from public corporations (Miyake 1908: 222-56). The most important of these was his argument that cities must have their own sources of funding. Miyake's way of thinking was similar to that of Seki Hajime, who favored taxing land value increases and included that item in Osaka city's budget even before the establishment of the betterment levy system.

A heated debate over funding sources took place among members of the City Planning Research Committee, focusing on subsidies as the key revenue source for city planning. The occurrence of this debate points up the fact that most members did not consider city planning to be a local issue, to be initiated by local governments. There was no adequate discussion of taxes on land value increase (as a city government revenue source) or a betterment levy and the return of development profits (linking city planning projects and funding). While the issue of city planning and funding was addressed to some extent in the pre-World War II period, it did not make significant progress.

\section{The centralized structure of the 1919 City Planning Law and the Urban Area Buildings Law}

As early as 1893, the Tokyo City Assembly had raised the question of whether the city lacked sufficient planning authority, despite having to bear virtually all project costs. This question, however, together with the issues of transferring decision-making power and establishing local funding sources, was not discussed at all by the City Planning Research Committee.

The 1919 City Planning Law and the Urban Area Buildings Law, both highly centralized, established Japan's modern city planning system (see also Chapter 5 by André Sorensen). Most of the members of the City Planning Research Committee, which drafted both laws, were central government officials. The only "local" representatives on the committee were the mayor of Tokyo (Tajiri Inejirô), the deputy mayor of Osaka (Seki Hajime), and the director of the Tokyo City Office (Fujihara Toshio). The governor of Tokyo (Tôkyô-fu chiji) and the superintendent general of the Tokyo Metropolitan Police Department (keishi sôkan) also sat on the committee, but were appointed by the central government rather than 
being locally elected. There was virtually no discussion of the decentralization of power or the issue of central versus local control.

It was under the 1919 City Planning Law that city planning was first applied to regional cities (other than Tokyo and the five metropolises, Osaka, Kyoto, Kobe, Nagoya, and Yokohama) and some municipalities. The framework for planning and decision-making on projects followed that of the Tokyo Urban Area Improvement Ordinance, and established the concept of city planning as a national project under the authority of the Home Ministry.

The Urban Area Buildings Law established a national building standard to replace prefectural regulations governing the construction of row-houses and other buildings. This standard was applied uniformly to both built-up areas and newly urbanizing suburban areas. In other words, the essence of the zoning concept was not included in the law, which ignored differences between places that were already urban and those in the process of urbanizing, leading to major problems later on.

By this time, a report published by the Deutscher Verein für öffentliche Gesundheitspflege (the German public health association) on Germany's unified building control system was introduced in Japan by Mori Ôgai, an army officer in charge of public hygiene and a well-known writer, in his essay "Okusei Shingi" (Current discussion on building ordinance) (Ishida 1999: 138-58). The German report raised the point that, in addition to setting a national minimum building standard, there should be some allowance for each local government to address its particular needs (Deutscher Verein für öffentliche Gesundheitspflege 1890: $1-60)$.

Although the City Planning Research Committee paid attention to regional differences - for example, the issue of streets in Osaka being too narrow to apply European building-height regulations - it did not consider introducing the idea of customizing standards or of applying stricter regulations to urban expansion or newly created built-up areas. Rather, it initiated uniformly loose standards.

\section{City planning during the war years, 1930-45}

Following the City Planning Law and the Urban Buildings Law, Japanese city planning in terms of techniques, practice, and administration underwent significant growth. By 1930 the City Planning Law had been applied in 97 cities and the reconstruction projects after the Great Kanto Earthquake in Tokyo and Yokohama were completed in that year. The centralized structure of the Japanese city planning system had been fully established by this time (Ishida 2004a: 87-145; Sorensen 2002: 114-42).

During the 1930s Japan marched deeper and deeper into the so-called Fifteen Years War (jûgonen sensô), which led directly to the country's involvement in World War II. The country's industrial growth accelerated around production for the war effort - a trend accompanied by urban expansion and the development of regional cities.

In 1932 the boundary of the city of Tokyo was expanded to match the city plan- 


\section{Ishida}

ning area, which corresponds to the current 23 boroughs (tokubetsu-ku). Tokyo's population reached 6.77 million in 1940, while that of Osaka exceeded 3 million and that of Nagoya, Kobe, and Yokohama increased to nearly 1 million each. The urban population, which constituted only 18 percent of the national population in 1920 , increased to 33 percent by 1935 . The need for city planning became greater in regional cities, and in metropolitan regions and areas where many cities were clustered, regional planning was, in fact, required.

\section{Urban growth and the diffusion of city planning to regional cities}

In 1933, the 1919 City Planning Law was amended so that it was applicable to all cities in Japan. By this time, the number of cities to which this law was applied exceeded 100. The number of officials working for the secretariats of local city planning committees (toshi keikaku chihô iinkai jimukyoku), which were attached to the prefectural offices but were agencies of the Home Ministry, increased significantly.

Prior to their work at these agencies, most officials had been involved in recovery projects following the Great Kanto Earthquake; therefore their transfer to local offices after completion of these rebuilding projects in Tokyo helped diffuse the techniques and expertise of city planning to regional cities. The fact that these local committee secretariats, responsible for drawing up city plans, were part of the Home Ministry reflects the centralized nature of city planning. At the same time, the location of the secretariats in local prefectures, instead of in the Home Ministry in Tokyo, contributed to a certain extent to the decentralization of city planning by enabling plans to be based on local situations and needs and facilitating cooperation with prefectural and municipal officials.

Among the transferred officials who made noteworthy contributions were Ishikawa Hideaki and Kaneiwa Den-ichi, city planning engineers employed at the local city planning committee's secretariat in Aichi prefecture who started a magazine entitled Toshi Sôsaku (City creation). Later they organized a study group on land readjustment by inviting engineers and officials of prefectural and municipal governments and landowners in the neighboring area, and founded another magazine, Kukakuseiri (Land readjustment), ${ }^{9}$ in order to publish the results of the study. Their efforts helped establish a unique, and to some degree, independent city planning framework in Nagoya and the Chûbu region. They also developed and put into practice new ideas, systems, and technology related to land readjustment and compiled a planning manual for land readjustment that preceded that of the central government (Ishida 1991).

\section{Military industries and the decentralization of city planning}

During the war years, from 1930 to 1945 , military production and other industries became more dispersed, to increase production and reduce vulnerability to bombing. The dispersal of facilities and factories to the suburbs and regional cities was accompanied by a decentralization of city planning. In the Tokyo metropolitan 
region, however, the unregulated relocation of war industries resulted in the diffusion of urban problems to suburban areas not yet covered by city planning.

The period also marked the beginning of the formulation of comprehensive plans for regional cities. These plans included the Military City Plan (gunto toshi keikaku) and the New Industrial City Plan (shinkô kôgyô-toshi keikaku), begun in the mid-1930s. There are 23 reported examples of such plans, extending from Aomori in the north to Nagasaki in the west. ${ }^{10}$ These occurred primarily in medium-sized to small regional cities and undeveloped areas not covered by city planning (Iwami 1978: 291-305). Master plans formulated during this time include the Sagamihara Military City Plan (centered around a military academy and army arsenal) (Nosaka 1940, City of Sagamihara 1971: 546-667); the Toyokawa New Industrial City Plan (navy arsenal); the Hiro New Industrial City Plan (steel plant) (Iwami 1978: 296-305); the Koromo New Industrial City Plan (automobile factory); and the Taga New Industrial City Plan (factory of heavy electrical machinery) (Sasatani et al. 1985). Most of these city planning projects, although they used land-readjustment techniques for project implementation, were not completed by the end of World War II, but continued into the 1950s (Iwami 1978: 294).

Here again, the dispersal and relocation of industries reflected and were spurred on by the policy of the central government. Whereas master plans were formulated by secretariats of local city planning committees, prefectural and municipal governments were responsible for implementing development projects. In many cases, although they received officials from the central government, the local governments employed new city planning officials locally and reinforced their city planning management structure (Sasatani et al. 1985). Thus, this period can be characterized as one of decentralization, in terms of both military industries and city planning.

\section{Postwar democratization and urban and regional planning policies}

\section{Priority on the provinces and dispersing overdeveloped cities during the postwar recovery period}

Japanese cities were devastated by Allied bombing in World War II. A total of 215 cities suffered some damage. The War Damage Restoration Plan (sensai fukkô toshi keikaku), further discussed by Nakabayashi Itsuki in Chapter 3, was applied to 115 severely affected cities. Many of these did not initiate the planning of recovery projects until the central government issued basic guidelines on war recovery projects in December 1945, four months after Japan's surrender (Ministry of Construction 1957-1963; Ishida 2003). Even after the war, city planning was still considered the task of the national government, and it seemed only natural for cities to wait for notification and orders from the upper levels of government. In fairness, it should be noted that cities lacked sufficient personnel, finances, and other resources to carry out their own planning. 


\section{Ishida}

One of the major goals of the basic guidelines was to control the excessive growth of large cities and promote smaller regional ones. This was logical, since the major cities at that time were devastated, heavy industrial facilities were for the most part destroyed, and urban residents were suffering from food shortages. Regional cities were given priority in the allocation of funds for recovery and proceeded to launch city planning projects on an unprecedented scale, including those covering all urban areas and large-scale land-readjustment projects.

During the recovery, prefectures and bombed cities improved their city planning capacity by hiring planners and engineers returning to Japan from former colonies and occupied territories. Nevertheless, most cities depended on plans provided by the central government and on technical standards such as land readjustment (which is a relatively standardized planning tool). As a result, they tended to be uniform and lacking in local initiatives. Critics retrospectively have blamed many of these plans for depriving regional cities of their traditions and local flavor.

\section{The Shoup recommendation and systems of city planning}

In May 1947, two years after the end of World War II, the new constitution and the Local Autonomy Law (chihô jichi hô) were enacted. Although this moment would seem to have offered a window of opportunity for a thorough reformation of systems of city planning based on empowered citizens and aligned with the concept of local governance, the central government's planning department did not take advantage of this opportunity. A draft prepared in 1948 to revise the prewar City Planning Law was basically the same as the old law, except that city planning decisions were delegated to the prefectural directors general (todôfuken shuchô) by the home minister as agents of the central government.

In August 1949, the Shoup Mission, a group led by the American economist Carl S. Shoup, issued its "Report on Japan Taxation" (Shoup shisetsudan Nihon zeisei hôkoku sho), a recommendation on ways to reform the Japanese tax system (Ishida 1987: 307-18). ${ }^{11}$ The report, in addition to commenting on general tax system reform plans, established principles for budget allocations and the reallocation of administrative services, and mentioned "local planning" or city planning as an example of administrative services that could be fully delegated to local governments (Shoup Mission 1949: A-8).

Upon receiving the Shoup Report, the Japanese government established a Committee to Study Local Administration (Chihô gyôsei Chôsaiin kaigi), known as the Kanbe Committee after its chairman. The Kanbe Committee produced its own "Recommendations on the Reallocation of Administrative Services" (gyôseijimu no saihaibun ni kansuru kankoku) in December 1950. These recommendations clearly stated that "City planning and city planning projects shall be the responsibility of municipalities. Laws shall be changed to give municipalities autonomous power to decide and implement matters related to city planning." The document even asserted that the legal structure of the 1919 City Planning Law hindered the autonomy of local public entities (Chihô gyôsei Chôsaiin kaigi 1952; Ishida 1987: 310-12). 
The central government ignored the committee's recommendation, at least for city planning systems, and the 1919 City Planning Law remained virtually unchanged until 1968. Incredibly, "air defense," added to the law in 1940 as one of the purposes of city planning, was not eliminated, even under the new constitution, which declared Japan's permanent renunciation of war. City planning was still regarded as a task of the central government, and local governments would implement what they were instructed to do. Citizens were not given any information about the decision-making process, nor were they able to participate in it - a trend that ran counter to the spirit of the new democracy.

It should be noted that from 1950 to 1952 the Ministry of Construction did try to amend, or made a pretense of trying to amend, the City Planning Law, under pressure from the Shoup Report and the Kanbe Committee's recommendations. The ministry issued its own draft of the law in 1952, which included provisions for decentralization and citizen participation (Ishida 1987: 312-18). The ministry, however, chose to keep the reins in its hands and stated that it was unwilling to transfer planning power to local governments. The reasons given included local governments' lack of planning resources; the notion that issues of decentralization and city planning were not limited to a single city but required regional planning; and the possibility of planning being distorted by the interests of local politicians. In the political climate that accompanied the developments of the Cold War and the conclusion of the San Francisco Peace Treaty and Japan-US Security Treaty, the Ministry of Construction was quick to abandon any notion of amending the City Planning Law.

The Building Standards Law (kenchiku kijun hô), issued in 1950, replaced the Urban Area Buildings Law of 1919. In terms of provisions relating to city planning, however, this new law was identical to the old because the City Planning Law was not revised before the enforcement of the Building Standards Law went into effect. Consequently, the Building Standards Law inherited from the old law its centralized character and nationwide uniform building standards.

\section{The Special City Construction Laws}

Unfortunately, there was very little outcry from local governments and citizens against the central government's antidemocratic stance committed to the continued centralization of city planning. One notable development during the early 1950s was the emergence of the laws apparently based on local initiatives. These were known as Special City Construction Laws (tokubetsu toshi kensetsu $h \hat{o}$ ), and were proposed by the members of the Diet at the request of specific cities. Examples include the Beppu International Tourism and Hot Spring Cultural City Construction Law (Beppu kokusai kankô onsen bunka toshi kensetsu hô) (1950); the Yokohama International Port City Construction Law (Yokohama kokusai kôto kensetsu hô) (1950); and the Ashiya International Culture and Housing City Construction Law (Ashiya kokusai bunka jûtaku toshi kensetsu hô) (1951). The laws were applied only to these specific cities and were enacted after popular referendums following resolutions made by the Diet. ${ }^{12}$ 


\section{Ishida}

This legislation procedure inclusive of citizen referendums, however, was carried out not to decentralize city planning but rather for "special financial considerations" or financial support for cities that were deemed special or unique and thus deserving of national attention. These cities did not intend to carry out their own city planning projects utilizing local financial resources. In fact, the Special City Construction Laws constituted a move against decentralization.

In addition, in 1950 the Capital Construction Law (shuto kensetsu hô) for the Tokyo metropolis was enacted. As discussed further in Chapter 3 by Nakabayashi Itsuki, it was designed to assist in the recovery and development of the capital - largely ignored during the immediate postwar period when the focus turned to regional cities, as discussed earlier. During the process of creating this law, the Tokyo Metropolitan Assembly (Tôkyô-to gikai) even requested that a central government agency be established to take charge of planning in the Tokyo borough area (Tôkyô-kubu). This can also be seen as an abandonment of self-governance (Ishida 1987: 273-6). Thus, the opportunity to decentralize city planning and involve more citizens in the planning process was completely lost in the early years after the end of World War II.

\section{Initiatives by progressive local governments and citizen movements in the 1960s and 1970s}

The 1960s through the 1970s were marked by the flourishing of progressive or innovative local governments (kakushin jichitai). Progressive governors were elected in prefectures with large cities such as Kyoto, the Tokyo metropolis, Osaka, Kanagawa, Fukuoka, and Saitama. Socialist or communist parties began to dominate many local assemblies in these major cities and metropolitan regions. These local governments took up initiatives on matters of social welfare and environmental pollution that the central government had either dragged its feet on or simply ignored (see also Chapter 6 by Watanabe Shun-ichi in this volume).

While city planning fell into a different category because of its centralized system of authority, and initiatives could not be adopted to the same extent, there were some unique planning approaches, such as in Yokohama (Tamura 1971: 116-75), and new attitudes toward citizen movement in city planning. In the late 1960s, many municipal governments tried to regulate the uncontrolled developments of their suburbs by establishing guidelines on residential land development (takuchi kaihatsu shidô yôkô). These movements urged the central government to introduce a development permit system in the 1968 City Planning Law (Ishida 1971; Nihon Hyôron-sha 1970). ${ }^{13}$

Additionally, during this time, citizen-led movements arose to safeguard green space, claim the right to sunlight, and resist land-readjustment projects. Many of these movements had a significant impact on the city planning policies of both the local and national governments. In 1968, a group of citizens established a national liaison association opposing land readjustment (kukakuseiri taisaku zenkoku renrakukai). The association's members studied theoretical and technical aspects of land readjustment, produced a newsletter, and published many books. It is widely acknowledged that these organized efforts by citizens influenced changes in the methods of land readjustment used. 
Citizen movements to protect residents' access to sunlight became active in the early 1960s. A group of citizens against "building nuisances" (kenchiku kôgai taisaku shimin rengô) formed in 1970. In 1973, the group made a direct proposal (chokusetsu seikŷu) to the Tokyo Metropolitan Assembly to enact the Sunlight Ordinance (hiatari jôrei). Although the proposal was rejected after a six-yearlong discussion, this campaign stimulated the introduction of provisions relating to restrictions on the blocking out of sunlight (nichiei kisei) into the amended Building Standards Law of 1976 (Kashiwagi and Nakabayashi 1988; Yûhikaku Jurisuto Henshû-shitsu 1974).

\section{The 1968 City Planning Law and decentralization}

\section{Decentralization and citizen participation}

With the 1968 City Planning Law, the issues of the decentralization of city planning authority and the participation of the citizenry were finally given consideration. The law, which was intended to have been formulated immediately after the end of World War II, was a case of too little too late, however, when it finally appeared after 20 years. Contrary to the recommendations of either the Shoup Mission or the Kanbe Committee, decision-making and implementation of city planning remained the task of the central government, to be delegated to local governments with the heavy intervention of the central government. In a slip of the tongue that was nonetheless accurate, Ôshio Yôichirô, the Ministry of Construction's director of city planning (Kensetsushô toshi keikaku kachô) commented that the new system for citizen participation introduced by the law was included simply to “stop citizens' claims that they didn't know about city planning projects" (Ôshio 1968: 68).

There were two problems with the delegation of city planning authority to local governments. First, decision-making powers were given mostly to prefectural governments; municipal governments had only limited control, over zoning and small projects. Under the law, municipalities found it very difficult to create comprehensive plans. Second, the upper levels of government retained strong involvement. Important prefectural plans and projects needed the approval of the central government, and municipal plans and projects required the prefectural government's consent. In cases of conflict between plans or projects, those of upper-level government were given priority over those from the lower ranks.

As a consequence, the fundamental notion that city planning is the national government's task - and the resulting top-down structure - remained unchanged under the1968 City Planning Law (see also Chapter 5 by André Sorensen in this volume).

\section{Institutionalization of citizen participation}

In its provisions for citizen participation, the 1968 law specified public hearings, explanatory meetings, displays of the draft plan, and a system whereby written opinions from the pubic could be submitted. Before the enactment of the law, city planning was just another administrative task about which the government would 
routinely keep its citizens in the dark. The new methods of popular participation included in the 1968 law marked a first step toward citizen involvement in the workings of central government (Ishida 1970) (see also Chapters 6 and 8 by Watanabe, and Hein and Pelletier respectively).

The citizens' movement seized on these new methods. Immediately after the enforcement of the 1968 City Planning Law and the 1970 amendment of the Building Standards Law, citizens had two major opportunities to participate in comprehensive plan-making. These were the demarcating of "urbanization promotion areas" (shigaika kuiki) and "urbanization control areas" (shigaika chôsei kuiki) in principal cities, and a nationwide revision of zoning plans based on the overhauling of the zoning system outlined in the 1970 amendment. Residents of Tokyo's Meguro borough became involved in the decision-making process of a rezoning plan of the whole borough area. During this process, citizens conducted a detailed survey of their local area, examined criteria for zoning set by the Tokyo Metropolitan Government (TMG), pointed out problems associated with the TMG's criteria, and came up with their own plan. Both Meguro borough and the TMG responded reasonably to the popular requests and came up with a plan that satisfied both sides (Takamizawa and Nakabayashi 1973).

In other cases, however, citizens often had to participate in the decision-making process without sufficient information and understanding of the plan's concepts and structure. In the city of Machida, located on the outskirts of Tokyo, citizens took part in the process of deciding on the urbanization control areas before the TMG and Machida officials formally explained the new planning system. Some citizens, primarily farmers, demanded that any plan to designate urbanization control areas be rejected, based on inaccurate information about the planning system they had received from a particular political group to manipulate them (Ishida 1973: 187-99).

\section{The 1980 revision of the City Planning Law and introduction of the district planning system}

The major problem of the 1968 City Planning Law and the 1970 amended Building Standards Law was that they provided only a system to deal with urban structures, which could not adequately address newly emerging community issues, such as quality of life and the environment (for example, the right to sunlight, and the further subdivision of land lots in built-up areas). In 1971, Tokyo Governor Minobe Ryôkichi proposed a model "district environment improvement project" (chiku kankyô seibi keikaku) in his plan "Tokyo Concepts on Open Space and Blue Sky" (hiroba to aozora no Tôkyô keikaku), designed to establish a system that would ensure the shibiru minimamu, or "civil minimum" - (minimum government services considered necessary for a satisfactory urban life). ${ }^{14}$ This was an attempt to emphasize the importance of the quality of urban living (Tokyo Metropolitan Government 1971). The two national laws of 1968 and 1970, however, did not provide a mechanism for approving and implementing these plans. The public had to wait until 1980 and the introduction of the district planning system (Ishida 2004a: 265-9). 
In 1980, both the City Planning Law and the Building Standards Law were amended and the district planning system (chiku keikaku seido) was introduced and then codified. The system assumed two new roles: that of supplementing the structure-level city planning system by district-level plans that were more practical and accessible to citizens; and that of creating a high-quality neighborhood and living environment based on local citizen consensus and through stricter and more detailed control of land use.

The amendment of the two laws was a major step toward decentralization and public participation. The creation of district plans became the task of municipalities, and the opportunities for citizens to become involved in the district plan decision-making process increased. From then on, building activities in district plan areas were to be regulated by municipal ordinances.

The system was modeled on the German Bebauungsplan (Federal Ministry for Regional Planning, Building, and Urban Development 1993: 16-27; Higasa 1981). At the same time, however, various innovative local approaches also had a hand in creating plans tailored to local needs even if they were limited to using conventional planning techniques (Morimura 1998: 126-83).

\section{The 1992 Amendment to the City Planning Law}

\section{Opposition parties' plan for decentralization}

In terms of decentralization and citizen participation, the significance of the 1992 amendment to the City Planning Law did not lie in the content of the law but in the process through which the revised law was enacted. Members of the opposition parties - those other than the Liberal Democratic Party (LDP) (Jimintô), then in power - submitted their own counter-bill to the Diet to compete with the government's proposed bill of amendment, a first in such a highly technical and specialized administrative field as city planning law. In addition, although the opposition's plan was submitted jointly by what were at the time the Socialist Party (Shakai-tô) and the United Social Democratic Party (Shakai-minshu rengô), many volunteers contributed to the preparation of the draft. The central figure in the volunteer group was Igarashi Takayoshi, a lawyer who later became a professor of law at Hôsei University. Other players included citizen groups involved with land-use issues and city planning, planners, local government officials, lawyers, and scholars in various disciplines (Igarashi 1994; Noguchi 1993).

The major difference between the central government's bill and that of the opposition was that in the latter more authority was granted to municipalities, and city plans required the approval of municipal assemblies (shi chô son gikai) - a more democratic process. On a more minor level, the counter-plan also proposed more zoning categories than the central government's plan.

Unfortunately, the LDP avoided discussion of this counter-bill and did not provide enough time for the two bills to be debated. Not surprisingly the counter-plan was voted down by the LDP, and the central government's plan was approved in the Diet, but only after a partial revision and a supplementary resolution reflecting some ideas proposed by the opposition. 


\section{Ishida}

\section{Local challenges and the central government's policy: the special land-use districts}

The City Planning Law as amended in 1992 added two new categories to the existing special land-use districts (tokubetsu yôto chiku), such as the special industrial district (tokubetsu kôgyô chiku) and the educational district (bunkyô chiku). These new districts were the exclusive commercial district (shôgyô senyô chiku) and a district called chûkôsôkai jûkyo senyô chiku, in which all upper floors of buildings must be reserved exclusively for residential use.

The debate between the Tokyo Metropolitan Government (TMG) and the Ministry of Construction over the introduction of the new categories was also noteworthy. The TMG demanded the addition of these two special-use districts and insisted that local governments be permitted to create such districts freely according to their needs. The Ministry of Construction, in contrast, took the old line that regulations on land use for city planning purposes should be set by national law, based on the spirit of Article 29 of the Constitution, which states, "Property rights shall be defined by law" (Ishida 2004a: 288-9).

This issue of local governance versus the law is a major point of contention in the debate over the right to enact ordinances and the decentralization of city planning authority. The Ministry of Construction has long clung to the view that the parameters for special-use districts should be stipulated by law and that the national government should set the framework and the scope of regulations through government ordinance (seirei) before allowing local governments to decide the content of regulations with their own ordinances. ${ }^{15}$

This policy can be criticized in light of the fact that the ministry has not provided the necessary planning tools and systems to local governments to meet the diverse needs of local regions and cities. Although various district- or block-level planning systems have been put in place recently, they have been primarily created for Tokyo and other metropolitan regions and have been geared to problems unique to those regions.

Beginning in the late 1960s through the 1970s, local governments took action toward controlling rampant lot subdivision and high-rise construction by establishing guidelines on land development (takuchi kaihatsu shidô yôkô) and on the construction of medium- to high-rise buildings (chû kôsô kenchiku shidô yôkô). With these problems largely ignored by the central government, local governments had to depend on administrative guidance (gyôsei shidô) which was often informal and not fully supported by laws or ordinances. In the 1980s, some innovative local governments enacted ordinances, based on these guidelines, to more broadly direct and regulate regional matters, including land-use control and environmental protection ordinances (Noguchi 1993: 170-206; Kobayashi 1999).

The central government tried to hobble these local movements, arguing that they were not within the scope of the legal framework or went beyond the national standard. One notable example is the ordinance established by the seaside resort town of Manazuru in Kanagawa prefecture that attempted to rein in uncontrolled development, which was responsible for environmental destruction and water shortages (Igarashi, Noguchi, and Ikegami 1996). 


\section{Municipal master plans and city planning}

The 1992 City Planning Law introduced a new system of "basic policies for city planning by municipalities" (shi chô son no toshi keikaku ni kansuru kihonteki na hôshin) (Article 18-2). This system has usually been interpreted as one in which a master plan established by a municipality guides the creation of individual plans by cities. Although the law states that municipalities "will provide" (sadameru mono to suru) a master plan, not "must provide" (sadamenakereba naranai) it, in practice this was obligatory, as every planning project by municipalities had to “conform with" (sokusuru) their municipalities' master plan.

It was expected that the master plan would help expand the role of municipalities in city planning, in terms of both administrative systems and practice. First, in principle, the master plan had to conform with the "basic concepts of the municipality's development decided on by resolution of the assembly," thus indirectly involving the assembly in city planning for the first time. Second, "measures to reflect citizens' opinions" were required through the holding of public hearings and meetings during the formulation of the plan. Finally, municipalities were forced to deal with broader city planning issues and thus improve their planning capabilities.

Many municipalities could not even begin to create a master plan until they had completed the plans for rezoning all areas to be planned, as stipulated by the 1992 law as having to be completed by 1995. As of December 1999, a total of 608 municipalities in Japan, or only 30.1 percent of all those requiring city planning, had formulated a master plan. This low rate is partly due to the municipalities' lack of planning experience and competence. Many prefectures and local research institutes began to put together guidelines to help these municipalities (Tôkyô shi chô son Jichi Chôsakai 1996; Kanagawa-ken Toshi keikaku ka 1996); ${ }^{16}$ and the Ministry of Construction has prepared an unofficial guideline for this purpose. To date, there is no consensus on the involvement of city planning consultants in the process.

The municipal master plan system was established based on the experience gained by innovative local governments and city planning experts since the late 1960s (Morimura 1998: 17-124). A comparison of several municipalities shows that, even after the 1992 amendment, a great variation in planning skills and approaches among municipalities remains. The extent of city planning knowledge on the part of citizens, who are now required to participate in planning, also varies considerably. Although some of the most important issues - protection of the natural environment and urban agriculture (Ishida 1990b; Gotô 2003) - are those that are discussed most enthusiastically by involved citizens, the City Planning Law, while it has undergone a series of amendments, is still insufficient to protect the environment as well as arable land.

\section{Decentralization, citizen empowerment, and future city planning legislation}

In 1999-2000 a grand project to reform the Japanese administrative structure, including that of city planning, by decentralizing it, was initiated with the Omnibus 


\section{Ishida}

Act for Decentralization of Powers. (This project was still ongoing in 2006.) The act was accompanied by a series of amendments to the City Planning Law and the Building Standards Law and related legislation that would be the first major revisions to the Japanese planning system since the two laws were enacted in 1968 and 1970.

The first major change in the laws took place in June 1999 with the promulgation of the Package Act, and sought to transform city planning administration from a system of "agency-delegated administrations" (kikan inin jimu), in which administrative functions were delegated to local governments as agencies of the central government, to one of local autonomy (jichi jimu), in which functions were initiated by local governments (Ishida 2004a: 310-14).

In October 1999, the Ministry of Construction posted on its website an interim report on scheduled forthcoming amendments and invited comments from the public. More than 500 proposals, including those from local governments, were collected and, while their impact was small, they were considered in the formulation of the content of the amendments.

The next step occurred when the Central City Planning Council (Toshi keikaku Chûô Shingikai) announced its advisory report in February 2000. In March, a bill to create two major amendments to the existing City Planning Law - supplementary provisions on decentralization and city planning tools that essentially changed the framework of the 1968 law - was submitted to the Diet, which approved it in May 2000.

\section{The effect of the 1999 amendment on the City Planning Law}

The effect of the changes in planning administration from kikan inin jimu to jichi jimu brought about by the 1999 amendment to the City Planning Law can be evaluated by an examination of the changes occurring in the relationships between the central government and local governments and in those between prefectures and municipalities (Toshi keikaku Gakkai Chihô bunken Kenkyû Shôiinkai 1999).

Principally, the amendment marked a change in the vertical relationship between different levels of government: between central and prefectural (the latter previously requiring the "authorization" (ninka) of the former), and between prefectural and municipal (plans by a municipality had needed the "approval" (shônin) of the prefecture). These relationships, which were usually politely termed kanyo (participation), were in reality nothing less than interventions (kanshô). According to the amended City Planning Law, however, the lower-tier government was to "consult with the upper-tier government and obtain its agreement." Although the term "consult" (kyôgi) would seem to imply the equal status of all levels of government, "agreement" (dôi) clearly meant that the earlier topdown relationship would be preserved.

Another example of the top-down system being maintained can be seen in Article 24 of the City Planning Law, concerning "matters of great importance to the interest of the country." In it, a provision allowing the central government to 
direct local governments in decisions affecting changes in city planning projects, and in some cases to make its own decisions and changes, was retained.

In addition, the national government retained financial control over city planning through the granting of subsidies. Without sufficient financial resources of their own, it is difficult for local governments to execute any city planning project that goes against the wishes of the national government.

The relationship between different levels of government is the major issue in decentralizing planning authority. The author submitted a letter of opinion to the Ministry of Construction in November 1999 outlining a concept for "consultation that requires 'mutual' approval" as the first step in establishing a more equal system in which municipalities become the initiators of city planning projects. ${ }^{17}$ No important infrastructure projects of national importance can be implemented without involving every area affected by the projects and without obtaining local consent. The same applies to projects by prefectures. While some may argue that projects can never be initiated until an agreement among all parties is reached, the author proposes to establish a system of arbitration, either in court or by other means.

The 1999 amendment also provided a legal basis for the Municipal City Planning Council (shi chô son toshi keikaku shingikai), which had heretofore been represented in every municipality, but only informally.

\section{The 2000 amendment to the City Planning Law}

A new bill passed by the Diet in May 2000 incorporated a number of changes to the City Planning Law. These include supplementary provisions for the decentralization of planning authority stipulated in the 1999 City Planning Law; drastic changes to the area demarcation (kuiki kubun, or more commonly senbiki) system instituted under the 1968 City Planning Law, that of categorizing city planning areas as either urbanization promotion or urbanization control sectors; changes to the development permit system; the expansion of the purview of the zoning system and the development permit system to extend their application to urban land use in areas outside the city planning areas; and the introduction of a new system for transferring development rights in urban redevelopment.

While it is beyond the scope of this essay to discuss each of these changes in detail, ${ }^{18}$ two issues bear a closer look: namely, the supplementary provisions for decentralizing planning powers, and the ways in which citizens and local governments can better exercise their power through these amendments.

The "outline of the bill" ( hôan yôkô), which briefly explained the bill's intentions, placed the supplementary provisions under items of "rationalization" (gôrika) of decision-making processes in city planning, as if they were not fundamental to the bill itself. These provisions, however, went beyond simple "rationalization" and addressed the issues of decentralization and participation. Notable was the establishment of a "suggestion system" (môshide seido) by which citizens, "interested individuals" (rigai kankeinin), or local governments could bring ideas for city or district plans to upper-tier governments. This provision was small but the 
first step toward creating a bottom-up system that would be empowered to consider and utilize citizens' or local governments' initiatives. To date, the amended City Planning Law has not provided formal mechanisms for these initiatives to be taken up by upper-tier governments or to be reflected in plans. Inevitably, for the system to operate successfully, it will be incumbent on local governments to elaborate and enact an enforcement ordinance. Many local governments have been struggling with this first and very difficult task, exchanging their ideas and experiences among local governments.

The amended law allows local governments to execute ordinances governing the participation of citizens and interested individuals in city planning decisions. Although the amended City Planning Law contains the passive proviso "unless contrary to legal regulations, the setting of provisions by the ordinance would not be hampered," this system represents a positive step toward helping local governments improve their citizen participation systems. The law can now be interpreted as granting legal authority to local governments and imposing upon them obligations to citizens.

As to the question of how citizens and local governments can better exercise their power through these amendments, the revised City Planning Law is significant in two aspects. First, the amended law allows for the "flexible operation" (jûnan na unyô) of city planning systems by local governments. One example of this type of flexible operation is the "option system" (sentaku-sei), for the senbiki system in town planning areas other than those in metropolitan regions, under which local governments are permitted to apply the system or not. Second, the amended law allows local governments to pass ordinances on many issues, including designation of areas where new types of land-use control are applicable, "technical standards" (gijutsu kijun) for development permits, and citizen participation in the planning process. Criteria for development permits have traditionally been established by legislation and cabinet orders; however, the amendments allow local governments to use ordinances to either strengthen or ease the standards.

As for the planning systems, a major goal of the 2000 amendment to the City Planning Law was to introduce new land-use regulation measures for areas other than urbanization promotion sectors, even encompassing land outside city planning areas - in other words, for all unbuilt areas. To this end, the new concept of a "gray" area between urbanization-promotion and control areas, a "quasi city planning area" (jun toshi keikaku kuiki), and a "specific-use buildings control area" (tokubetsu yôto seigen kuiki), along with systems to control development and building activity in these areas, have been introduced. Significantly, the designation of these areas and the operation of the system are for the most part entrusted to local governments, in particular municipalities (Ishida 2004a: 315-22; Nihon Toshi keikaku ka Kyôkai 2003: 9-27).

As has been observed, decentralization is also a major trend in terms of planning tools, which will increasingly fall under the jurisdiction of ordinances enacted by local governments. This corresponds to the opposition parties' 1992 plan to amend the City Planning Law, which called for the greater involvement of local assemblies in city planning. In other words, local governments will have to 
assume a greater responsibility in improving local environments and local living conditions by making the most of the power to plan that has been granted to them.

One concern regarding the amended City Planning Law is the definition of what the revised law terms "national interest" (kuni no rigai). If the central government equates projects of "national interest" solely with such works as bullet trains and highway networks, new airports, military bases, or relocation of the capital, and tries to intervene in city and regional planning by local governments, it will most assuredly run contrary to the spirit of decentralization. Clearly, the central government has a responsibility to guarantee a minimum level of government services required to maintain a basic level of environmental protection and standard of living, a responsibility that was abdicated when a concept to "strengthen systems to protect and create green space," proposed in the interim report of the Central City Planning Council in 1999, was not included in the amendments to the law. This is particularly relevant, since the central government still controls finance and taxation without giving sufficient financial independence to local governments.

\section{Ongoing progress and current problems: 2000-5}

Since the 1999-2000 amendments to the City Planning Law, the decentralization of planning authority and functions has continued to move forward, although it vacillates between the central government's policies and local initiatives. In 2005, it remains difficult to summarize and evaluate the ongoing situations, other than to offer several fragmentary comments.

Three policies established by the central government are noteworthy. These are the Special Measures Law on Urban Regeneration (toshi saisei kinkyû tokubetsu sochi hô), in short the Urban Regeneration Law (toshi saisei hô), enacted in March 2002; the policy to forcibly merge cities and municipalities (shi chô son gappei sokushin); and the so-called three-in-one reform (sanmi ittai teki kaikaku) of the local finance and taxation system (chihô zeizaisei seido). The Urban Regeneration Law enables the central government to designate Urban Regeneration Areas of Urgent Needs (toshi saisei kinkyû seibi chiiki) and to focus directly on implementation of the urban regeneration projects (toshi saisei jigyô) in these areas (Ishida 2002, 2004a: 323-6). The number of Japanese cities and municipalities had been reduced gradually since the enactment of the Exceptional Law on Local Government Amalgamation (shi chô son gappei tokurei hô) in 1965 - from 3,392 to 3,229 in 2000. The central government amended the law via the Package Act for Decentralization of Powers in 2000 and planned to reduce the number of cities and municipalities to one-third of those in 2000, employing more powerful promotion measures. According to a briefing by the Ministry of Internal Affairs and Communications (Sômushô) on April 14, 2005 (Sômushô website), the number was 2,521 at the end of March 2005 and will be 1,822 in 2006. The excessive amalgamation of cities and municipalities and the resulting enlargement of administrative areas will cause many problems in the decentralization of urban and rural planning. While the three-in-one reform aims to reduce or abolish 
national subsidies and expenses (kokko hojo futan-kin) for local projects, to transfer tax revenue sources (zeigen ijô) to local governments, and to review the local allocation tax system (chihô kôfuzei seido), even at the end of 2005 the specific means by which to realize these reforms was still being debated among the central government, the ruling political parties, and local governments.

In the arena of local government and citizens' initiatives, recent significant contributions include an array of local planning ordinances (Kobayashi 2002) and the creation of many types of nonprofit organizations related to urban and rural planning. There have also been some unsuccessful local efforts to elaborate new local ordinances to compensate for inadequate amendments to the national laws. For example, many local governments were forced to enact ordinances to possibly prohibit high-density condominiums built on high-pitched slopes - which could have many sub-standard housing units in the basement - as a result of the irrelevant 1994 amendment to the Building Standards Law (Ishida 2004b). Most of these efforts, however, largely promote the decentralization of urban and rural planning. In 2004, Kokubunji city in Tokyo, for instance, adopted the new comprehensive planning ordinance after intense discussion among citizens that covered almost all issues, including those delegated to local governments by recent amendments to the planning laws and those particular to the city (Matsumoto 2005). During this process the city sought the temporary input (shukkô) of invited officials experienced in planning-ordinance legislation, not from the central government or the TMG, but from a local government in the Kanagawa prefecture, which had considerable administrative experience in enacting and enforcing planning ordinances. Kokubunji city's planning ordinance, and the process by which it was legislated, would become the model for other local governments.

\section{Conclusion}

The foregoing discussion has attempted to outline the history of modern city planning in Japan in terms of the centralization or decentralization of planning authority. During the Meiji period of the nineteenth century, planning was not centralized, with the exception of the capital city of Tokyo. In many cases local governments adopted their own initiatives; or rather, they were forced to do so because of neglect by the central government. Along with the modernization of Japan came a long period of centralization, spanning the pre-World War II and postwar periods. City planning failed to keep up with trends toward democracy and popular participation until the 1968 City Planning Law was enacted. Even after 1968, citizens and local governments continued to apply pressure to further decentralize planning.

As discussed earlier, three issues that required central intervention were pointed out concerning centralization and decentralization in city planning. Those include ways to handle city planning not limited to a particular city or area, empower local governments and improve their planning capacity, and prevent intervention in local politics, which may hamper effective planning. This essay has also examined the issues of local governments' lack of financial power in city planning and centralized (using the term in a legal context) land-use control. 
An analysis of these issues indicates that democracy in local governance, emphasizing citizens and their initiatives, is the key to achieving decentralization. The issue of land-use control by national and local governments is a prime exemplar. In legal terms, the two major effects of the national law have been to set the lowest common denominators for land-use control to guarantee a "national minimum" and to authorize local governments to establish their own land-use control measures to cope with issues specific to their region. On the other hand, empowered local governments must take several steps in order to utilize that authority, formulate an adequate land-use plan, and exercise effective city planning. These include undertaking studies of the social factors of land ownership and land-use rights, the examination of new concepts of land-use rights based on such studies, and the establishment of a land-use planning system that is clear to citizens based on these concepts.

In the age of decentralization that lies ahead, it is imperative that citizens be involved at every step of the planning process. Outcomes should be shared by citizens and used to reach consensus in land-use plans. Once this is accomplished, Japan will have achieved democratic city planning centering on citizens and their initiatives. Meeting this grand challenge will mean nothing less than the creation of a new planning culture (keikaku fûdo) in Japan (Ishida 2004a: 326-34).

\section{Notes}

1 Machi kaisho refers to autonomous bodies of townsmen (chônin) that operated during the Edo period and were especially active in merchant and port towns. In Edo (later Tokyo), however, their activities were limited mainly to relief for the poor.

2 Streets in the city center of Osaka were originally planned and constructed in 1594-9 by Toyotomi Hideyoshi and had a width of 7.8 meters (east and west) and 6.0 meters (north and south) in the Edo period.

$3 K u$ refers to an administrative unit in major cities that have a population of more than half a million and are so designated by cabinet order (seirei shitei toshi, literally Cabinet Ordinance Designated Major Cities) and the Metropolis of Tokyo. There are two types of $k u$, those with a local assembly and publicly elected head and those without. For the purposes of this chapter the former can be translated as borough and the latter as ward. Tokyo only allowed the former since 1947 . For the history of Tokyo's $k u$, see Ishida (2000a: 191-221).

Kubukai, the Sectional Meeting of the Tokyo Municipal Assembly, was composed of members from the 15 wards of Tokyo. In 1889 the area comprising the 15 wards became the City of Tokyo.

4 The 1919 City Planning Law used almost all provisions of the 1909 Agricultural Land Readjustment Law (kôchi seri hô) corresponding to its land-readjustment system. This simple and easy legislation caused unexpected difficulties. The draft, however, applied only a few selected provisions that had been necessary in the cases of Osaka and Kobe.

5 For biographical information on Seki Hajime and his work related to urban problems facing Osaka, see Shibamura $(1989,1998)$ and Hanes (2002).

6 Akagi Suruki also introduced a number of arguments regarding the centralization of planning power around 1919, when the City Planning Law was enacted (Akagi 1968: 502-9).

7 For the historical development and an analysis of the concept and system to recoup the betterments in Japan, see Ishida (1990a). 
8 The American historian and political scientist Charles Austin Beard (1874-1948) was invited in 1922 by Gotô Shinpei, the mayor of Tokyo, to serve as an adviser on urban administration. Beard also gave lectures on urban policy in many cities. After the Great Kanto Earthquake of 1923, he returned to Japan and offered many suggestions regarding reconstruction.

9 The reprinted edition of Kukakuseiri was published by Kashiwa-shobô in 1991. After World War II, a magazine with the same name was published, and it still exists; however, these two magazines are independent of each other.

10 Though not designated as New Industrial Cities, some regional small towns, such as Oguni-machi in Yamagata prefecture, accepted dispersion of munition industries and worked to create industrial parks and to improve built-up areas.

11 Carl Sumner Shoup (1902-99) was an American economist. After graduating from Stanford University, he received his doctoral degree from Columbia University in 1930. He went to Japan in 1949-50 as the head of a mission to study and recommend revisions for Japan's taxation system. He also worked as the head of taxation missions to Venezuela and Liberia.

12 The results of the referendums were mostly affirmative, with the exception of that on Tokyo, in which 44.9 percent of voters abstained and 39.7 percent objected.

13 For urban policies by reformist local governments in general, see Ishida (1971) and Nihon Hyôron-sha (1970). Although historical studies on their achievements have been insufficient, for Tokyo see Tôkyô Jichi mondai Kenkyû-sho (1994).

14 "Civil minimum" was a term coined by Governor Minobe and his advisers. For details and an analysis of Minobe's "civil minimum" policy on city planning, see Ishida (1971: 192-204).

15 A 1998 amendment to the City Planning Law abolished national control over specialuse zoning. This is another example of a change effected in the legal system through the initiative of local governments.

16 In 1986 Tokyo shi chô son Jichi Chôsa-kai, a research institute on local administration, was created for the cities and municipalities of Tokyo Metropolis. The establishment of many organizations of the kind has accompanied decentralization.

17 In March 2000, the author was invited to the Lower House Construction Committee as an expert to give an opinion on the bill of revision and proposed the same concept. See the Proceedings of the Committee on Construction of the Lower House, Term 147, No. 8: 5-9 (available online at http://kokkai.ndl.go.jp/SENTAKU/syugiin/147/0014/main. html).

18 For details and an analysis of the changes in the Japanese city planning system since 1995, see, for example, Ishida (2000b, 2000c, 2004a: 315-22) and Nihon Toshi keikaku ka Kyôkai (2003).

\section{References}

Akagi Suruki (1968) “Toshi keikaku no keikaku sei” (Possibilities of urban planning), in Toshi Kenkyûkai, Tokyo Metropolitan University (ed.) Toshi kôzô to toshi keikaku (Urban structure and urban planning), Tokyo: Tôkyô Daigaku Shuppankai, pp. 499539.

Beard, Charles A. (1923) Beard hakase kôenshû (Lectures by Dr. C.A. Beard in Japan), Tokyo: Tôkyô Shisei Chôsakai.

Chihô gyôsei Chôsaiin kaigi (ed.) (1952) Chihôgyôsei chôsaiin-kaigi shiryô (Documents of the investigative commission on local administration), Tokyo: Chihô gyôsei Chôsaiin kaigi.

City of Kure (ed.) (1924) Kure-shi shi, dai 1-shû (History of the city of Kure, vol. 1), Kure: City of Kure. 
City of Sagamihara (ed.) (1971) "Gunto-keikaku jidai no Sagamihara" (Sagamihara in the years of military city planning), in Sagamihara-shi shi dai 4 kan (History of the city of Sagamihara, vol. 4), Sagamihara: City of Sagamihara, pp. 546-67.

Deutscher Verein für öffentliche Gesundheitspflege (ed.) (1890) Deutsche Vierteljahrschrift für öffentliche Gesundheitspflege vol. 22, Braunschweig: Friedrich Vieweg und Sohn.

Fujimori Terunobu (1982) Meiji no Tôkyô keikaku (Plans for Tokyo in the Meiji era), Tokyo: Iwanami-shoten.

Federal Ministry for Regional Planning, Building, and Urban Development (ed.) (1993) Federal Building Code, Administrative Measures Act to Supplement the Federal Building Code; Federal Land Use Ordinance and Model Building Regulations, Bonn: Federal Ministry for Regional Planning, Building and Urban Development.

Gotô Mitsuzô (2003) Toshi nôchi no shimin-teki riyô (Urban arable land and citizens' use), Tokyo: Nihon Keizai Hyôron-sha.

Hanes, Jeffrey E. (2002) The City as Subject: Seki Hajime and the Reinvention of Modern Osaka, Berkeley, CA: University of California Press.

Higasa Tadashi (ed.) (1981) Chikukeikaku: toshi keikaku no atarashii tenkai (District planning: new development of city planning), Tokyo: Kyôritsu Shuppan.

Igarashi Takayoshi (1994) Giin rippô (Legislation by the House members), Tokyo: Sanseidô.

Igarashi Takayoshi, Noguchi Kazuo, and Ikegami Shûichi (1996) Bi no jôrei - ikizuku machi wo tsukuru (City beautiful ordinance - creating lively communities), Kyoto: Gakugei Shuppan-sha.

Ishida Yorifusa (1970) "Toshi keikaku to jûmin-sanka" (Urban planning and citizens' participation), in Bessatsu Keizai Hyôron dai 2 gô (Special issue of Keizai Hyôron, no. 2), Tokyo: Nihon Hyôron-sha, pp. 119-25.

_(1971) "Kakushin jichitai no toshi keikaku" (City planning by reformist local governments), in Nishiyama, Uzô (ed.) Toshi keikaku to machizukuri (Kôza, Gendai Nihon no toshi mondai, dai 2 kan) (City planning versus machizukuri (Series, Urban problems in contemporary Japan, no. 2)), Tokyo: Chôbun-sha, pp. 163-222.

_(1973) "Toshi keikaku no kettei-katei ni okeru jûmin sanka: Shigaika-kuiki oyobi shigaika chôsei-kuiki ni kansuru toshi keikaku wo rei toshite" (Citizens' participation in decision-making on planning of urbanization promotion areas and urbanization control areas), in Nihon Gyôsei Gakkai (ed.) Seisaku kettei to kokyô sei (Public interest in policy decisions), Tokyo: Keisô Shobô, pp. 174-214.

- (1987) Nihon kindai toshi keikakushi kenkyû (Studies on the history of Japanese urban planning), Tokyo: Kashiwa Shobô.

- (1990a) "Kaihatsu-rieki no kangen no rekishi to hôsei" (History and legislation of betterment levy in Japan), in Ishida Yorifusa (ed.) Daitoshi no tochi mondai to seisaku (Land problems and policies in the metropolitan region), Tokyo: Nihon Hyôron-sha.

- (1990b) Toshi nôgyô to tochiriyô keikaku (Urban agriculture and land-use planning), Tokyo: Nihon Keizai Hyôron-sha.

(1991) "Senzen no kukakuseiri gijutsu seido no tôtatsuten wo shimesu" (Achievements of land adjustment system and technique in prewar days), in Kukakuseiri Fukkoku-ban, Kaidai/Mokuji (Reprint of Kukakuseiri: Bibliographical introductions/index), Tokyo: Kashiwa Shobô, pp. 5-18.

-(1999) Mori Ôgai no toshiron to sono jidai (Mori Ôgai's essays on urban problems in the context of his time), Tokyo: Nihon Keizai Hyôronsha.

- (2000a) "Réformer et nommer les divisions de la ville à Tokyo: machi et ku depuis la Restauration Meiji," in Christian Topalov (ed.) Les divisions de la ville, Paris: UNESCO/La Maison des sciences de l'Homme, pp. 191-221. 


\section{Ishida}

Ishida Yorifusa (2000b) "21-seiki no toshi nôson keikaku wo tenbô suru" (The future of urban and rural planning in the twenty-first century), Keizai 59: 79-93.

- (2000c) "Toshi keikaku hô no kaisei to tochi riyô ken, tochi riyô keikaku, tochi riyôkisei" (The revised town planning law and the right to use land, land-use planning, and land-use control), Nihon fudôsan gakkai shi 54: 18-24.

- (2002) "Nijûisseiki no toshi nôsôn seibi no kadai to keikaku no yakuwari" (Issues in urban and rural areas and roles of planning in the twenty-first century), Kenchiku to Machizukuri 303: 7-13.

- (2003) "Japanese Cities and Planning in the Reconstruction Period, 1945-55," in Carola Hein, Jeffry M. Diefendorf, and Ishida Yorifusa (eds.) Rebuilding Urban Japan after 1945, Basingstoke: Palgrave Macmillan, pp. 17-49.

- (2004a) Nihon kingendai toshi keikaku no tenkai 1868-2003 (The development of Japanese modern and contemporary urban planning 1868-2003), Tokyo: Jichitai Kenkyû-sha.

- (2004b) "Rekishi he no muchi arui wa bôtoku: Chikashitsu manshon-mondai to kenchiku kijun hô dai 30 jyô" (Ignorance of or insult to history: condominiums having underground housing units and the abolition of Article 30 of the Building Standards Law), Kanagawa Soken Shohô 128: 1-9.

Ishida Yorifusa and Furusato Minoru (1980) "Kyôto toshi kaikaku dôro jigyô juekisha futankin hantai undô (1924-1940) ni tsuite" (Studies on citizens' campaigns against betterment levy concerning street-widening projects in Kyoto (1924-1940)), Toshi keikaku ronbun shû 15: 25-30.

Iwami Ryôtarô (1978) Tochi kukakuseiri no kenkyû (Studies on land readjustment), Tokyo: Jichitai Kenkyûsha.

Kanagawa-ken Toshi keikaku ka (ed.) (1996) Shi chô son masutâpuran sakutei no tebiki - shi chô son dokujino torikumi no tame ni (Guidelines to municipal master plans - for unique planning by municipalities), Yokohama: Kanagawa-ken Toshi keikaku ka.

Kashiwagi Satoru and Nakabayashi Itsuki (1988) "Hiatari jôrei to machizukuri no jûmin undô" (Sunlight ordinance and citizens' campaign for community planning), in Ishizuka Hiromichi and Ishida Yorifusa (eds.) Tôkyô: seichô to keikaku 1868-1988 (Tokyo: urban growth and planning 1868-1988), Tokyo: Center for Urban Studies, Tokyo Metropolitan University, pp. 244-52.

Kobayashi Shigenori (ed.) (1999) Chihô bunken jidai no machizukui-jôrei (Machizukuri ordinances in the age of decentralization), Kyoto: Gakugei Shuppan-sha.

-(2002) Jôrei ni yoru sôgô-teki machizukuri (Comprehensive machizukuri based on ordinances), Kyoto: Gakugei Shuppan-sha.

Koshizawa Akira (1991) Tôkyô toshi keikaku monogatari (Stories of urban planning projects in Tokyo), Tokyo: Nihon Keizai Hyôron-sha.

Matsumoto Akira (2005) Machizukuri jôrei no sekkei-shisô: Kokubunj-jôrei ni miru bunken machizukuri no messeeji (Legislative ideas in the machizukuri ordinance of Kokubunji city), Tokyo: Daiichi Hôki.

Ministry of Construction (ed.) (1957-63) Sensai fukkô shi: zen 10 kan (The history of war reconstruction projects, 10 volumes), Tokyo: Toshi keikaku Kyôkai.

Miyake Iwao (1908) Toshi no kenkyû (Studies on the city), Tokyo: Jitsugyô no Nihon-sha.

Morimura Michiyoshi (1998) Masutâ-puran to chiku kankyô seibi (Master plan and district improvement), Kyoto: Gakugei Shuppan-sha.

Nihon Hyôron-sha (ed.) (1970) Tokushû: kakushin kichitai (Special issue on reformist local governments), Bessatsu Keizai Hyôron dai 2 gô (Special issue of Keizai Hyôron, no. 2), Tokyo: Nihon Hyôron-sha. 
Nihon Toshi keikaku ka Kyôkai (ed.) (2003) Toshi nôson no atarashii tochiriyô senryaku (New strategies for land-use planning in urban and rural areas), Kyoto: Gakugeki Shuppan-sha.

Nishikawa Kôji, Fujimoto Atsushi, and Mutô Tadashi (eds.) (1989) Machi ni sumau: Ôsaka toshi jûtaku shi (Living in town: the history of urban housing in Osaka), Tokyo: Heibonsha.

Noguchi Kazuo (1993) Kaisetsu to katsuyô hô: kaisei toshi keikaku hô (Commentary and usage of the revised city planning law), Tokyo: Jichitai Kenkyûsha.

Nosaka Sukeyuki (1940) "Sagamihara toshi kensetsu kukakuseiri jigyô" (Land readjustment projects in Sagamihara new industrial city), Toshi Kôron 23(3): 16-41. Repr. in Kanagawa-ken Toshiseisaku-ka (ed.) (1985) Kanagawa-ken Toshiseisakushiryô (Compilation of the documents on planning history of Kanagawa prefecture, 1928-45), Yokohama: Kanagawa-ken Toshiseisaku-ka, pp. 53-68.

Ohara Keiji (2002) Kobe no machizukuri to Meiji no kukakuseiri (Kobe's machizukuri and land readjustment in the Meiji period), Kobe: privately printed.

Ôshio Yôichirô (1968) Shin toshi keikaku hô no yôten (The gist of the new town planning law), Tokyo: Jûtaku Shinpô-sha.

Sasatani Yasuyuki, Yamagata Kôichi, Koyanagi Takekazu, Endô Tsuyoshi et al. (1985) "Senchûki no Taga-machi no toshi keikaku" (Town planning of Taga-machi during World War II), Toshi keikaku ronbunsh û 20: 37-42.

Seki Hajime (1917) "Shigaichi kukakuseiri seido oyobi chiikiteiki tochishûyô seido" (Urban land readjustment system and zone expropriation system), Kokumin Keizai Zasshi 23(1): 47-64 and (2): 1-19. Repr. in Seki Hajime (ed.) Kôbe Toshimondai Kenkyû-sho (1992) Jûtaku mondai to Toshi keikaku (Housing problems and city planning), Tokyo: Gakuyô-shobô, pp. 343-78.

Shibamura Atsuki (1989) Seki Hajime - Toshi shisô no paionia (Seki Hajime - a pioneer of urban ideas), Kyoto: Shôraisha,

-(1998) Kindai toshi no seiritsu - 1920/30 nendai no Ôsaka (Materialization of a modern city: Osaka in the 1920s and 1930s), Kyoto: Shôraisha.

Shoup Mission (1949) Nihon Zeisei Hôkokusho: Report on Japanese Taxation vol. 3. Tokyo: GHQ (General Headquarters)

Sômushô website http://www.soumu.go.jp/s-news/2005/050414_3.html

Sorensen, André (2002) The Making of Urban Japan: Cities and Planning from Edo to the 21st Century, London: Routledge.

Sumisaki Tsutomu, Kobayashi Shigenori, and Ôba Satoru (1981) "Kyû toshi keikaku hô seitei zengo ni okeru tochi zôka zei no seidoka dôkô ni kansuru kenkyû" (Studies on the failed institutionalization of taxes on land-value increase discussed in the early decades of the twentieth century), Toshi keikaku ronbunshû 16: 67-72.

Suzuki Eiki (1991) "Nihon kindai toshi keikaku shi ni okeru chôkashûyô ni kansuru kenkyû" (Studies on excess condemnation system in Japanese modern planning history), unpublished doctoral dissertation, Tokyo University.

Takamizawa Kunio and Nakabayashi Itsuki (1973) "Chiiki chiku shitei-gae to jûkankyô no hozen" (Alternation of zoning plan and preservation of living environment), Jûtaku 22(7): 60-6 and (8): 43-9.

Tamura Akira (1971) "Kakushin toshizukuri no hôhô ron" (Methods of innovative city planning), in Asukada Ichio (ed.) Jichitai kaikaku no jiissenteki tenbô (Actual prospect of local government reform), Tokyo: Nihon Hyôron-sha, pp. 116-75.

Tanaka Yoshio (1991) "Meiji zenki ni okeru kenchiku-hôsei ni kansuru kenkyû: nagaya kaoku kenchiku kisoku no seiritsu katei" (Studies on building ordinances in the 


\section{Ishida}

early years of Meiji: enforcement of house regulations and row-house regulations), unpublished doctoral dissertation, Waseda University.

Tôkyô Jichi mondai Kenkyû-sho (ed.) (1994) Nijûisseiki no toshi jichi he no kyôkun (Lessons for urban local autonomy in the twenty-first century), Tokyo: Kyôiku-shiryô Shuppan-kai.

Tôkyô shi chô son Jichi Chôsakai (ed.) (1996) Tama-ban machizukuri gaidorain sakutei chôsa hôkokusho (Report of guidelines on master plans for municipalities in the Tama area), Tokyo: Tôkyô Shi chô son Jichi Chôsakai.

Tôkyô Shisei Chôsakai (ed.) (1929) Honpô toshi keikaku jigyô to zaisei (Urban planning projects and finances), Tokyo: Tôkyô Shisei Chôsakai.

Tôkyô-to Zaisei shi Kenkyû kai (ed.) (1969) Tôkyô to zaisei shi: dai 1-shû (History of financial affairs of Tokyo Metropolitan Government, vol. 1), Tokyo: Tokyo Metropolitan Government.

Tokyo Metropolitan Government (TMG) (ed.) (1971) Hiroba to aozora no Tôkyô kôsô (Tokyo plan with public space and blue sky), Tokyo: Tokyo Metropolitan Government.

Toshi keikaku Gakkai Chihô bunken Kenkyû Shôiinkai (ed.) (1999) Toshi keikaku no chihô bunken - machizukuri he no jissen (Decentralizing of planning powers - toward the practice of machizukuri), Kyoto: Gakugei Shuppan-sha.

Tsubohara Shinji (1995) Kobe no kindai toshi keisei shi (History of Kobe's urban development), doctoral dissertation, Kobe University.

Watanabe Shun-ichi (1987) "Kyû toshi keikaku hô no seiritsu katei ni okeru Ôsaka shigai kairyô hô sôan no ichi" (Historical place of the Osaka Urban Area Improvement bill in the formative process of the City Planning Act, 1919), Toshi keikaku ronbunshû 22: 109-14.

_(1993) Toshi keikaku no tanjô: kokusai hikaku kara mita Nihon kindai toshi keikaku (The birth of urban planning: Japan's urban planning in international comparison), Tokyo: Kashiwa shobô.

Yûhikaku Jurisuto Henshû-shitsu (ed.) (1974) Tokushû nisshô-ken (Jurisuto-zôkan) (Special issue on the right to enjoy sunshine (Jurist-extra)), Tokyo: Yûhikaku. 


\title{
3 Concentration and deconcentration in the context of the Tokyo Capital Region Plan and recent cross-border networking concepts
}

\author{
Nakabayashi Itsuki
}

From 1600 onward, when it was selected as the center of government by the first shogun of the Tokugawa regime, Edo grew rapidly, becoming the largest city in the world by the eighteenth century - despite several civil disasters. The Meiji restoration of 1868 changed the name of the metropolis from Edo to Tokyo and it was this city that became the capital of a modernizing nation. During the Meiji and Taisho periods, Tokyo went from a city of 1 million to one of 2.5 million people.

\section{Tokyo's reconstruction after the Great Kanto Earthquake, and the first stage of deconcentration in the 1930s}

The Great Kanto Earthquake of 1923 rocked the Tokyo and Kanagawa prefectures and caused severe damage in both Tokyo and Yokohama. In the wake of this disaster, the population of Tokyo city dropped from 2.5 million to 1.5 million. The evacuation of 1 million people to the countryside and suburbs was, in part, a temporary response, but it also represented a permanent migration to the suburbs. The population of Tokyo's inner areas never returned to its pre-disaster level and was outstripped by the growth in the suburban areas. During the reconstruction of Tokyo between 1923 and 1930, not only did people move to the neighboring suburbs, but large factories and temples were relocated there as well, as a result of completion of land-readjustment projects in central Tokyo. It can be said that this phenomenon was the first "centralized deconcentration" of Greater Tokyo. These neighboring suburbs were developed without urban and site planning and, as densely built areas of wooden houses surrounding the center and sub-centers of Tokyo, were the most vulnerable to the devastation wrought by earthquakes (Nakabayashi 1980: 111).

The revival and growth of Tokyo's industrial strength in the 1920s was astonishing. During this period, many factories were constructed in the suburbs outside central Tokyo. Some of these suburbs, such as Fuchû, Musashino, Higashi-Murayama, and Akishima, were located in cities in the outlying areas of Tokyo. Others were in the adjacent prefecture of Kanagawa, in Kawasaki and Sagamihara, approximately 20-40 kilometers from the heart of Tokyo. Others lay still farther out, such as Ôta in Gunma prefecture, some 40-80 kilometers from the center of the capital. 
By the 1920s, the Keihin industrial zone, one of the four largest industrial zones in Japan, was spreading along the coast between Tokyo and Yokohama. ("Kei" signifies Tokyo and "hin" Yokohama.) Along with the factories, residential districts constructed for workers were developed without site planning, resulting in unrestrained growth and sprawl. In 1924, the year after the Great Kanto Earthquake, at the International Conference on City Planning held in Amsterdam, a proposal was made for a regional planning system to control this sprawl. This concept called for metropolitan planning based on satellite cities and green belts. By the 1930s, regional planning became the focus of considerable discussion in Tokyo.

The regional plans for Greater Tokyo were drawn up after the reconstruction of Tokyo (Figure 3.1). One was the Kanto National Land Plan of 1936 (Kantô kokudo keikaku); the other was the Tokyo Green Space Plan (Tôkyô ryokuchi keikaku) of 1939 (Figure 3.2). These offered a way to prevent the uncontrolled growth of Tokyo by creating green belts and removing the industrial functions from central Tokyo to satellite towns, using the establishment of industry promotion zones on the outer edge of Greater Tokyo as an incentive (Ishida 1987: 180-5).

Against the background of regional planning during the 1930s, the clouds of war were gathering. The City Planning Law (toshi keikaku hô), which had been enacted as a modern urban planning system in 1919 and initially applied to the major cities (see Chapter 2 by Ishida Yorifusa in this volume), was finally realized for all cities in 1933. However, in 1937 the Air Defense Law (bôku hô) was passed, which entailed the relocation of factories for defense against aerial bombing and



Figure 3.1 Conceptual plan for the Kanto region and Greater Tokyo (Toshi keikaku Tôkyô chihô iinkai) published in 1940 by Tokyo city planning local committee. Source: Ishida (1987: 183). 




Figure 3.2 Tokyo Green Space Plan (1939). Source: Tokyo Metropolitan Government (1994: 36).

the creation of green belts around the built-up area of Tokyo as military protection. Subsequently the Urban Building Law (shigaichi kenchiku butsu hô), which had also been enacted in 1919, was revised in 1938 to include a new system of zoning open space in urban areas (kûchi chiku seido). Significantly, this planning was a strategic national project conducted until the end of World War II not by the Tokyo prefecture (Tôkyô-fu) but by the Home Ministry (Naimushô) which after the war was divided into the Ministry of Local Affairs (Jichishô) and the Ministry of Construction (Kensetsushô).

A new administrative system was established after the war, with implications for planning. The hierarchy extended from the national government to the prefecture (Tôkyô-to, Hokkai-dô, Ôsaka-fu, Kyôto-fu and 43 prefectures (ken)) to the lower levels of local government (city, town, and village, or shi, chô/machi, and mura/son). A city (shi) is classified principally as a "great" city or Cabinet Ordinance Designated Major Cities (seirei shitei toshi), having a population of over approximately 1 million, a "big" city (chûkaku shi), more than approximately 200,000 , and an "average" city (shi). Tokyo's system is exceptional in that central Tokyo is composed of 23 special wards (tokubetsu ku), although the regular system of city, town, and village exists in the Tama suburban region. A "great" city has powers almost identical to that of the prefecture in terms of independent policy-making and administration. There are 15 cities with this status: Sapporo, Sendai, Chiba, Saitama, Kawasaki, Yokohama, Shizuoka, Nagoya, Kyoto, Osaka, 
Kobe, Hiroshima, Kitakyushu, Fukuoka, and Sakai city. At the same time, the special wards of Tokyo have had almost the same status as an "average" city in this regard since the 1970s. Despite a trend toward the deconcentration of power in Tokyo, its mayor has power to affect the administration of the wards. In the city planning system, the land-use regulation zoning plan (yôto chiiki seido) and the plans of large-scale infrastructures, such as roads and parks, are designated by the mayor of the Tokyo Metropolitan Government (TMG).

\section{A postwar reconstruction plan for Tokyo and the development of a concept for Tokyo's decentralization}

The Allied bombing in 1945 razed 162.3 square kilometers, some 27 percent of the 23 wards that compose the traditional center of Tokyo. Almost half the homes in the ward area - approximately 759,000 houses - were burned down. Many people were evacuated from Tokyo, but numerous others stayed behind. A total of 93,000 households (approximately 310,000 people) were living in makeshift shelters among the ruins as of September 1, 1945, just two weeks after the end of the war.

In 1946, the national government devised a strategic initiative for reconstructing 115 devastated cities (see also Chapter 2). Within these cities, a total area of 632 square kilometers had been bombed and 2.3 million houses burned. More than 330,000 people had been killed. The foundation of this initiative was that the reconstruction and revitalization of local cities would have primacy over the rebuilding of large cities, especially Tokyo. This was intended to preclude an insatiable surge in demand for housing, food, jobs, and various services that would occur if people were to rapidly return to large urban centers, in which these necessities were in acutely short supply.

Even before this initiative was issued, what was known as the Reconstruction Plan for Tokyo (Tôkyô sensai fukkô keikaku) emerged, modeled essentially on the wartime planning concept devised under the leadership of Ishikawa Hideaki, chief planner of Tokyo prefecture. This concept consisted of two kinds of plans: a plan for the rebuilding of central Tokyo ( $k u$ - $b u$, in Japanese, the 23-ward area) and a regional plan for the entire Kanto region.

The reconstruction plan for central Tokyo was decided in 1946, and set a target population of the center of 3.5 million (half the peak prewar population) and called for the reduction in size of the capital itself through the designation of green belt zones around the central city and the creation of open spaces to separate the residential zones. Considering that the population of the Tokyo ward area had been approximately 6.5 million at its prewar zenith, the rehabilitation plan was clearly overly optimistic (Figure 3.3). The plan's goal was to reduce the size of the central city and to distribute the population and industries into suburban cities following the idea of the satellite city, a concept proposed at the International Conference on City Planning that took place in Amsterdam in 1924.

Ishikawa believed that Tokyo was destined to grow and become a magnet for population and industries. Accordingly, he created several plans, including a 


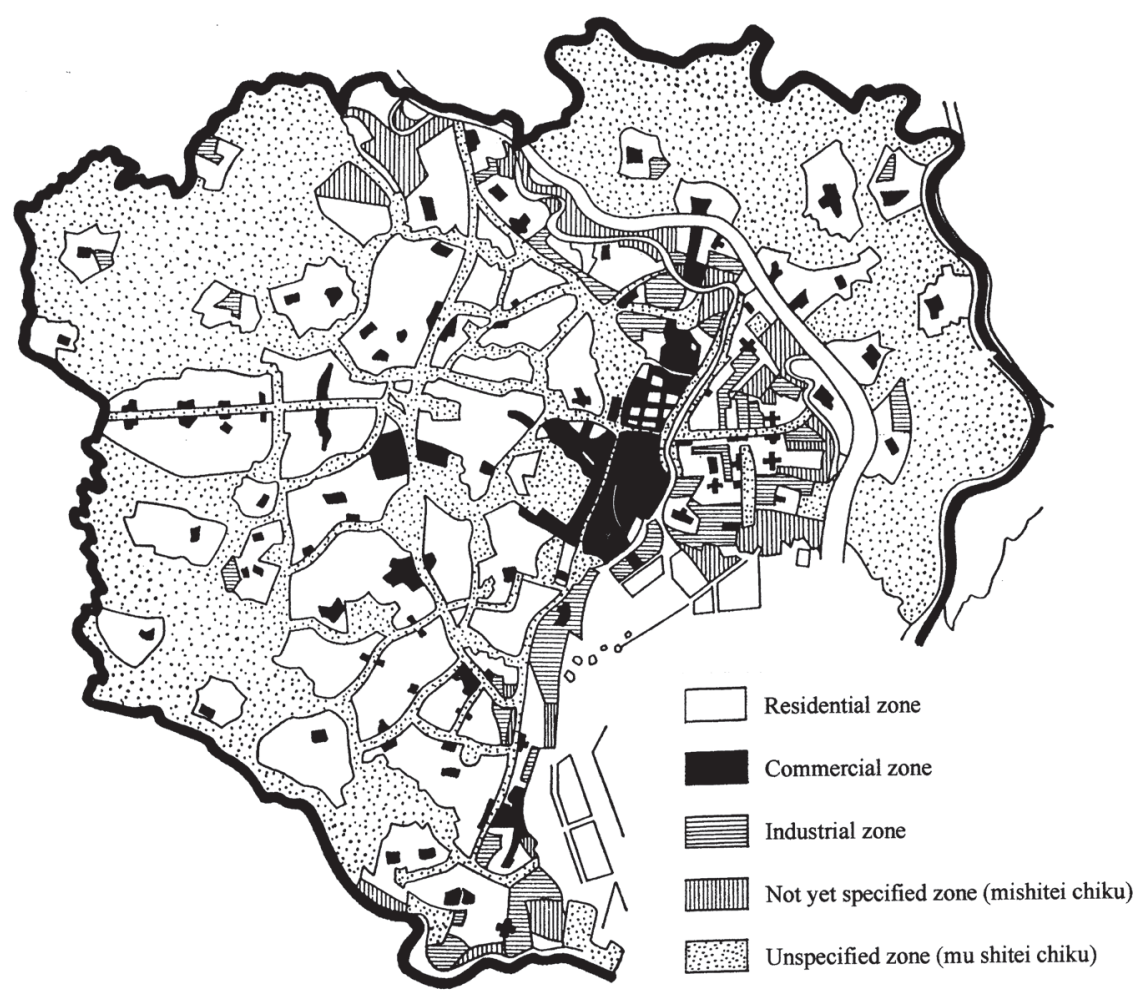

Figure 3.3 Land-use plan as part of the Reconstruction Plan for Tokyo (1946). Source: Ishida (1987: 224). Just after the air bombings of Tokyo in 1946, land use was unclear in many districts, which thus were designated "not yet specified" zones (mishitei chiku). Land use in "unspecified zones" (mu shitei chiku) was not specified in order to reserve land for the future.

plan to restrict growth in central Tokyo and a plan to redistribute inhabitants and industries to suburban cities in the Kanto region, not only to Tokyo prefecture but to other prefectures, such as Kanagawa, Saitama, Chiba, Ibaraki, Tochigi, Gunma, Yamanashi, and Shizuoka. These idealistic ideas to rehabilitate Tokyo were repudiated, however, as there was no system in place for a regional plan beyond the prefectural boundary. The plan for central Tokyo was promulgated in 1946, but the regional plan of Kanto was not designated at this time. In his plan for central Tokyo published under the title "Tokyo Reconstruction Plan after the War," Ishikawa commented, "Although Tokyo will become an industrial city in the future, the priority for the present should be on development as a political, economic, and cultural center. When the time comes, its political and cultural functions shall be moved to other areas" (Ishikawa 1993a: 708-11).

The regional plan for the Kanto region focused mainly on areas in the surrounding prefectures of Tokyo. This plan envisioned a population of approximately 5 million through the expansion of existing cities located within a 40- to 50-kilometer radius of central Tokyo as satellite cities beyond a green belt. These satellite 
cities were each projected to have a population of 100,000. Among them were Yokosuka, Hiratsuka, and Atsugi in Kanagawa prefecture; Hachiôji, Tachikawa, and Machida in Tokyo prefecture; Kawagoe, Omiya, and Kasukabe in Saitama prefecture; and Chiba, Noda, and Kashiwa in Chiba prefecture. The regional plan also included suburban cities with an anticipated population of around 200,000, to be attained by expanding the major existing cities, such as Odawara in Kanagawa prefecture, Mito in Ibaraki prefecture, Utsunomiya in Tochigi prefecture, Maebashi and Takasaki in Gunma prefecture, Kofu in Yamanashi prefecture, and Numazu in Shizuoka prefecture. The existing cities would be within a 60- to 100-kilometer radius of central Tokyo (Ishikawa 1993b: 596) (Figure 3.4).

Tokyo prefecture drew up the reconstruction plan for central Tokyo with the approval of the national government, but without any discussion with neighboring prefectures. Moreover, Tokyo prefecture had no authority to adopt the Kanto regional plan for other prefectures and no power to implement the plan for cities that were not a part of its territory. This regional plan for the greater metropolitan area was only a visionary scheme at this time - with no possibility of being carried out. It was not until 1958 that a plan for the Kanto region was accepted, when the first Tokyo Capital Region Plan (shutoken seibi dai ichiji kihon keikaku) was drawn up by the national government.

As a result, Tokyo's master plan for reconstruction came under the land-use regulation system of the Special City Planning Law (tokubetsu toshi keikaku hô)

(a)





(b)

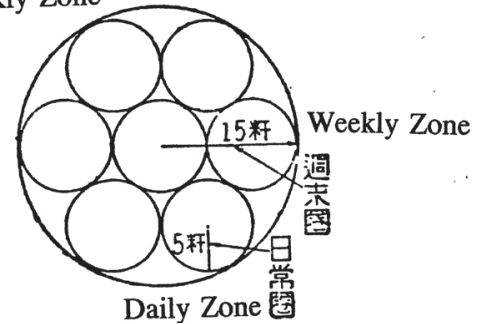

Figure 3.4 Sketches for regional planning as part of the reconstruction plan for Tokyo proposed by Ishikawa Hideaki (1946). Source: Ishikawa (1993b: 596). (a) Hierarchy of residential zones for daily, weekly, and monthly life needs. (b) The Kanto region. 
in 1946, but without being designated a regional plan. Both land-readjustment projects and road network construction projects were scaled back dramatically. Although this land-use plan envisaged a population of 3.5 million people in the Tokyo ward area by the allocation of a wide "green space" in accordance with land-use zoning (mushitei chiiki) and with so-called green space zoning (ryokuchi chiiki), the actual postwar growth of Tokyo was so rapid that the population of the ward area increased from 1.5 million in 1945 to 3.44 million by 1946 , to 3.82 million by 1947, and 5.38 million by 1950 (Ishida 1987: 226).

\section{From the National Capital Construction Law (shutoken seibi hô) to the National Capital Region Development Law and the first National Capital Region Development (NCRD) Plan (dai ichi shutoken seibi kihon keikaku)}

Faced with accelerated population growth and severe financial constraints, Tokyo appealed to the national government to enact a law under which the latter would be directly responsible for constructing a capital for Japan out of the wards of Tokyo. This meant in effect that Tokyo asserted its autonomy of city planning. Voters of the Tokyo metropolitan area approved this legislation (at 55 percent participation) with 60 percent voting to accept. As a result, the National Capital Construction Law (shuto kensetsu hô) was enacted in 1950 and the National Capital Construction Committee (shuto kensetsu iinkai) established in 1951.

The National Capital Construction Committee produced a five-year plan for national capital construction (shuto kensetsu kinkyû goka nen keikaku) in 1952, mainly to provide parks and green spaces for the ward area of Tokyo. The committee proposed the Plan of Freeways in the Capital Region (shuto kôsoku dôro keikaku) in 1953, and drafted a Conceptual Plan for Capital Region Development (shutoken seibi kôsô keikaku soan) in 1955. Although the National Capital Construction Law (shuto kensetsu hô) covered only the Tokyo wards, the committee considered a conceptual plan for capital region development. As the capital region would extend beyond the boundary of Tokyo and the city's workers commuted from outside Tokyo prefecture's territory in the early 1950s, with this conceptual plan, the committee discussed different approaches to the development of a National Capital Region that would encompass an area extending to a 50-kilometer radius from the heart of Tokyo, of which the ward area occupied the area within a 15- to 20 -kilometer radius. The 20 - to 50 -kilometer radius zone included a green belt development and a cluster of smaller cities to be developed as satellite cities in suburban areas, besides the urban renewal zone in central Tokyo (Figure 3.5). This conceptual plan for the development of the Capital Region was modeled after the Greater London Plan of 1944 (Figures 3.6 and 3.7). The Japanese plan divided the Capital Region into three zones according to distance from the center: the Inner Urban Zone (naibu shigai chitai), the Suburban Zone and Built-up Area (kinkô chiiki and shigaika kuiki), and the Peripheral Zone and cities within that zone (shûhen chiiki and shûhen toshi). The conceptual plan called for a green belt to be established in the Suburban Zone, and the existing cities to be developed as 
(a)
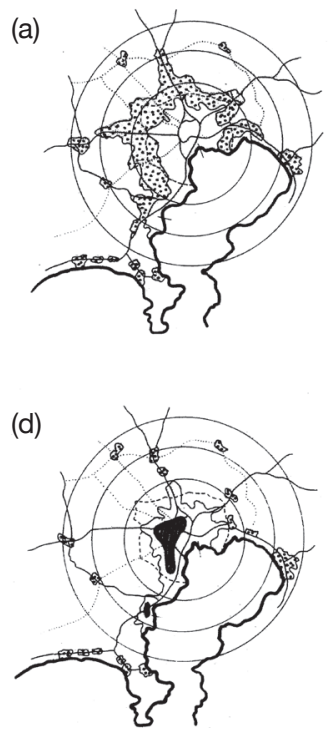

(b)



(e)

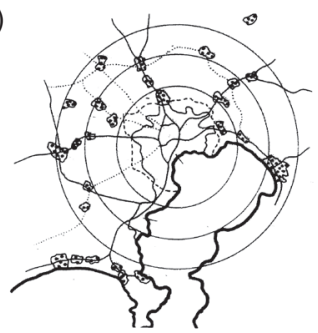

(c)

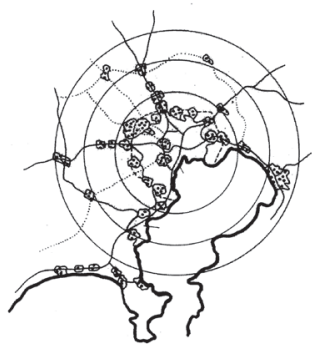

(f)

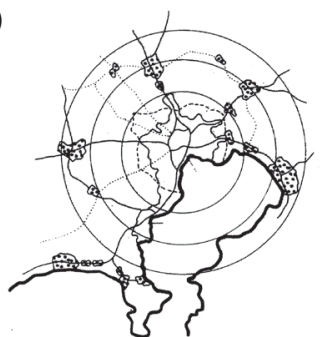

Figure 3.5 Comparison of development approaches proposed for the Capital Region by the National Capital Construction Committee (NCCC). Source: City Planning Institute of Japan (1988: 45). (a) Uncontrolled expansion. (b) Suburban fringe development. (c) Cluster of small cities development. (d) Urban renewal development. (e) Linear development. (f) Special cities development.

satellite cities in the Peripheral Zone. In addition to the green belt and satellite cities, a key issue was the appropriate size of the primary city - central Tokyo - for the region as a whole. The tremendous demands of Tokyo's growth necessitated the development of a new plan that would extend the metropolis beyond Tokyo proper. To achieve this, a new planning system for the development of the Capital Region that would cross prefectural boundaries ("cross-border") was legislated in 1956 (Nakabayashi 1983: 14-16; Kawakami 1990: 14-15).

The National Capital Region Development Law (shutoken seibi hô) of 1956 replaced the National Capital Construction Law (shuto kensetsu hô) of 1950. The purpose of this new law was to provide a solution to overcrowding, traffic congestion, and urban sprawl in the Tokyo metropolis and surrounding suburbs. The law redefined the Capital Region to cover an area within a 100-kilometer radius from the heart of Tokyo, rather than the 50-kilometer radius specified in the earlier conceptual plan. This larger area included the entire Kanto Plain and consisted of eight prefectures: all of Tokyo, Kanagawa, Saitama, and Chiba prefectures in southern Kanto; and parts of Ibaraki, Tochigi, and Gunma, all in northern Kanto, and Yamanashi prefectures. The first National Capital Regional Development (NCRD) Plan was established in 1958 (Figure 3.7).

The 1958 NCRD Plan divided the Capital Region into three sub-regions: the Existing Urbanized Area (kisei shigaichi, defined as the built-up area in 1955) as the primary city in an inner sub-region; the "Proposed" Suburban Zone (kinko chitai "yotei chi") as green belts including existing towns in a suburban sub-region; 


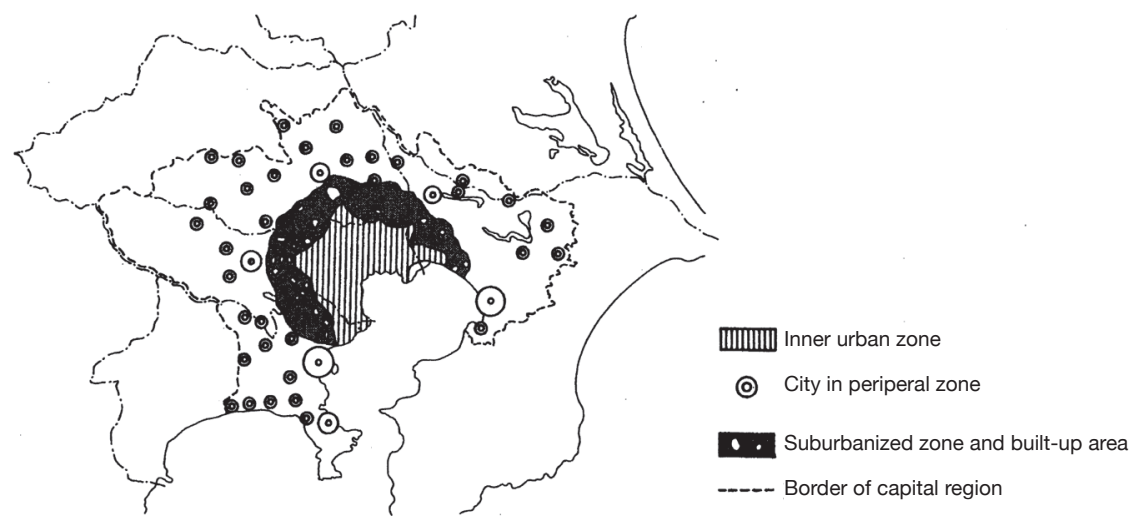

Figure 3.6 Conceptual plan for the development of the Capital Region by the National Capital Construction Committee (NCCC) (1955). Source: Kawakami (1990: 15).

and the New Urban Development Area (shigaichi kaihatsu kuiki) as satellite cities in a peripheral sub-region. The strategic goal of the first NCRD plan was to curtail the expansion of central Tokyo through the creation of green belts and the relocation of industrial functions away from central Tokyo and into the satellite cities.

Limiting the expansion of the Existing Urbanized Area, however, could not solve the problem of Tokyo's burgeoning growth. Both the establishment of green belts with development of satellite cities and the redevelopment of inner areas were important responses to this issue.

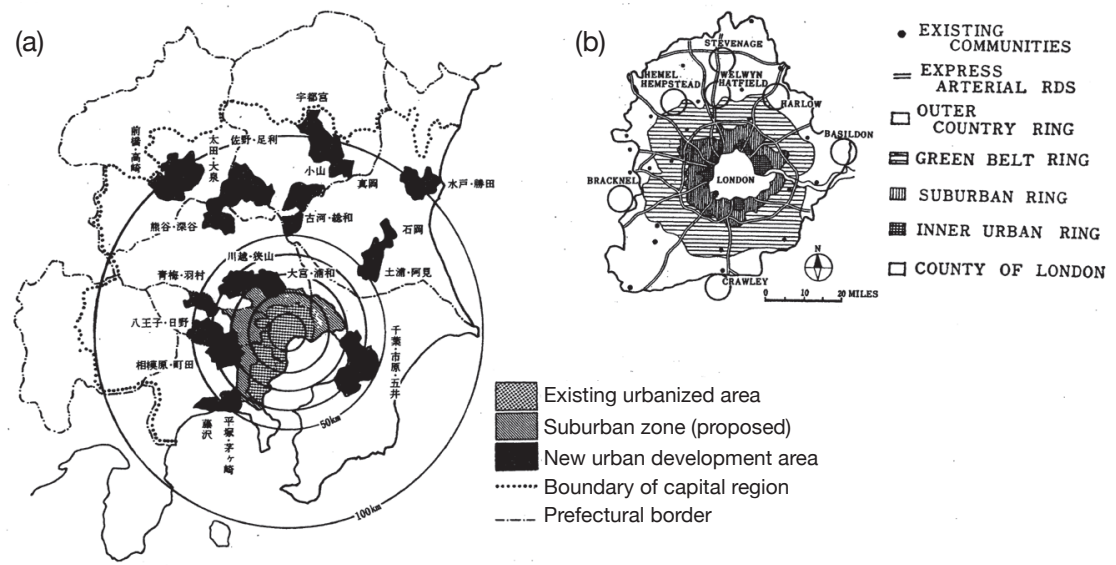

Figure 3.7 Comparison of the first National Capital Region Development (NCRD) Plan (1958) and the Greater London Plan (1944). Sources: Nakabayashi (1983: 16) and Ishida (1987: 275). (a) The first NCRD Plan (1958). (b) The Greater London Plan (1944). 


\section{Nakabayashi}

In the 1960s, urban redevelopment projects designed to transform the ward area of Tokyo into a high-density city were promoted within the Existing Urbanized Area. Under this policy, new systems for high-density land use were established. One example was the Super Block Development System (tokutei gaiku seido) of 1961; another was the Floor-area Ratio Regulation System (yosekiritsu seido), which regulated building volume but not height. It was brought into effect previously in Tokyo in 1963, and the Kasumigaseki Building, opened in 1968, is the first high-rise building with a height of more than 100 meters. This Floor-area Ratio Regulation System was fully brought into effect with the abolishment of the absolute height limit of 30 meters and the change of both the City Planning Law in 1968 and the Building Standards Law in 1970. These new systems paved the way for the construction of high-rise buildings more than 30 meters high.

The concept of the green belt was the dream of many Japanese city planners since the 1924 International Conference on City Planning. Planners were eager to include a green belt system under the first NCRD Plan, along with simultaneous industrial and residential development in the satellite city zones to relieve the pressure on Tokyo to expand. This crucial planning concept, however, met with strong resistance from landowners and all 16 cities occupying the proposed green belt zone. In fact, the land-use controls for the conservation of green space specified in Tokyo's reconstruction plan were deregulated for the needs of urbanization, especially for the construction of public housing. As a result, the green space zones earmarked by the Special City Planning Law for reconstruction after World War II were radically reduced. Urban expansion of central Tokyo could not be controlled and new residential areas sprang up, creating sprawl. Concerns centered around the control of these zones and belts and the means by which landowners would have received compensation. The plan thus was unable to realize its initial objective of limiting the size of the Existing Urbanized Area. At the same time, Tokyo's industries grew more rapidly than expected and many factories were relocated away from central Tokyo. In the suburban areas, urban sprawl continued in the development of both residential and industrial areas that had not yet combined into satellite cities (Nakabayashi 1983: 16-18).

In order to control new development and the construction of large factories and universities in the Existing Urbanized Area, a new law was promulgated in 1959, the Factory Regulation Law in Tokyo Capital Region's Existing Urbanized Area (shutoken no kisei shigaichi ni okeru kôgyô tô seigen hô). In spite of the new law, however, the influx of people and industries into the Capital Region could not be limited sufficiently and caused the size of the population to exceed all expectations. Although the first NCRD Plan envisioned a target population of 26.6 million within a 100-kilometer radius by 1975 , the actual population reached 27 million by 1965 - a decade earlier than anticipated (Ishida 1987: 271-7).

This ballooning of the Existing Urbanized Area and lack of implementation of the green belt proposal represented a major failure in cross-border regional development, the goal of which, in addition to decentralization, was to suppress the emergence of a huge metropolis without adequate green space. The various local governments in the Tokyo Capital Region - which in 1956 consisted of 
eight prefectures (Tokyo, Kanagawa, Saitama, Chiba, Ibaraki, Tochigi, Gunma, and Yamanashi), two "great cities (Yokohama and Kawasaki), and more than 250 local governments (cities, towns, and villages) - had been unable to work together effectively to realize a regional development plan that would distribute green space and urban development evenly. Consequently, every local government pushed for urban development and ideal plans for the Tokyo metropolis were relinquished. A number of scholars have subsequently viewed as one of history's ironies the fact that this failure of planning and the resulting extreme concentration of economic activities in Tokyo in fact gave the Japanese economy an extra impetus for growth.

\section{From green belt to "metropolitanization": the second NCRD Plan}

The NCRD Law was radically amended in 1965, according to the conceptual plan by the National Capital Development Committee (shutoken seibi iinkai) for new development of the Capital Region (Figure 3.8). The amendment abolished the green belt concept and expanded the target area to cover all territories of eight prefectures, extending to the mountains of the northern Kanto region, which included the catchment area of the Tone River. Many dams were constructed within this catchment area to supply water to Tokyo.

In 1968, a second NCRD Plan (dai niji shutoken seibi kihon keikaku) was announced. It divided the capital region into three new sub-regions: the Existing Urbanized Area (as in the first plan), the Suburban Development Zone (kinkô seibi chitai), and the New City Development Area (toshi kaihatsu kuiki). The Suburban Development Zone, corresponding to an area within a 15- to 50-kilometer radius from the center of Tokyo, consisted mainly of green belts and the new urban development areas designated as satellite cities under the first plan. The Suburban Development Zone was designed to help develop planned urban areas that included the preservation of valuable small green spaces and was based on the Suburban Green Space Preservation Law (kinkô ryokuchi hô) enacted in 1968. These small green spaces, however, were not substitutes for a green belt, as there were very few of them (Ishida 1987: 277-80). The New City Development Zone was a designated Peripheral Zone beyond a 50-kilometer radius from the center, covering new manufacturing and other industrial satellite cities, but encompassing areas other than those assigned to the New Urban Development Area under the first NCRD plan,

The revised concept for the second NCRD Plan called for the development of Tokyo as a metropolis that would feature planned development and avoid suburban sprawl. Its basic policy went from the earlier regulation of "metropolitanization" using green belts to the planned growth of the metropolis. In terms of planning strategy, its aim was to counter the centralization in Tokyo with a deconcentration of urban functions from the Existing Urbanized Area to the Suburban Development Zone and New City Development Areas in the northern Kanto region beyond a 50-kilometer radius from Tokyo's center. 


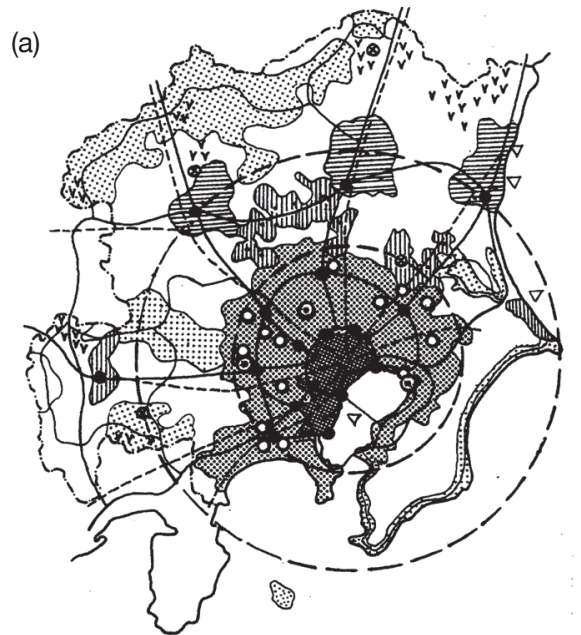

Existing urbanized area
Suburban development zone
Expanding city development area
- Rew city development area
- Recressway (highway)
- Distribution service center
- Universition business district
- Industrial city
- Large-scale residential district
$\nabla$ Port

(b)
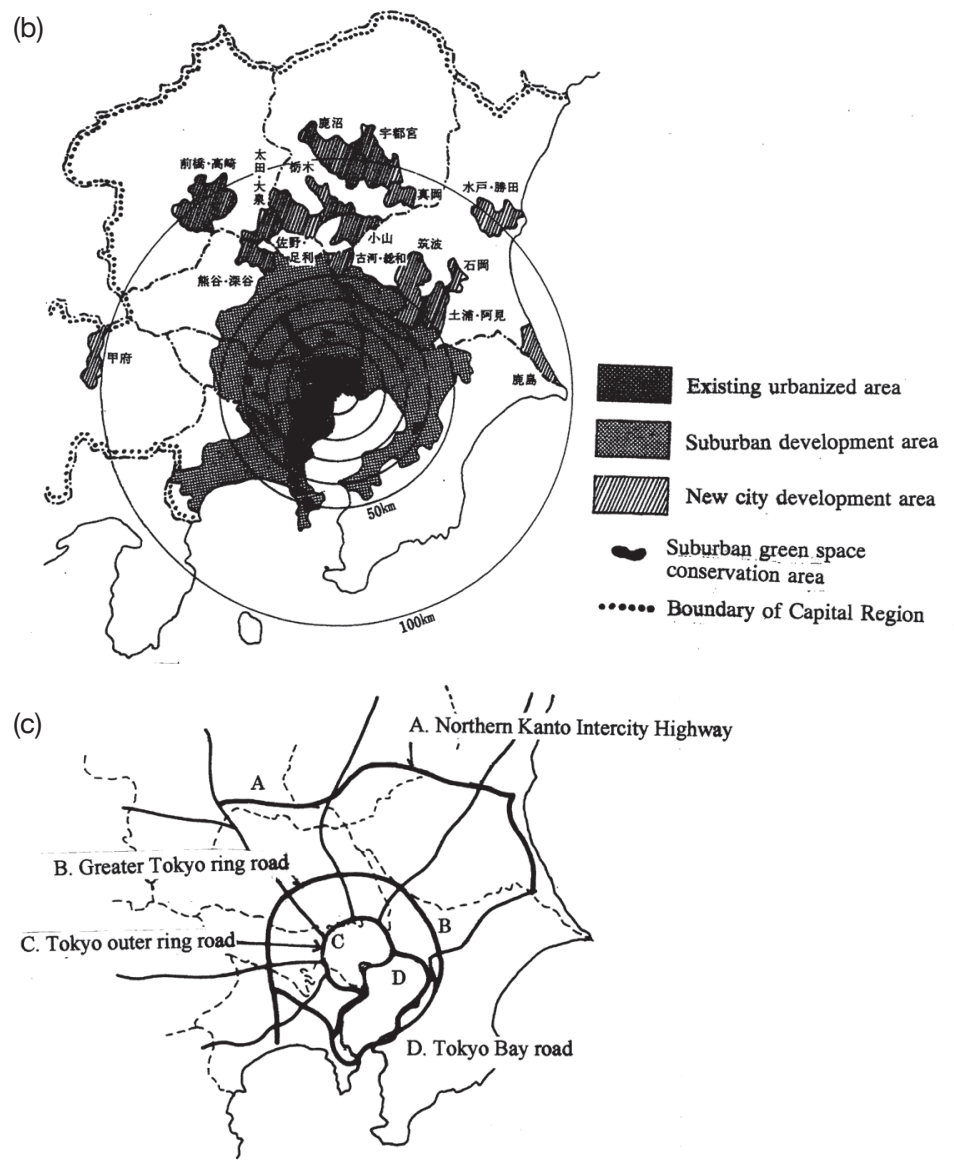

Figure 3.8 (a) Proposed concept for the second NCRD Plan (1967). Source: Nakabayashi (1983: 16-17). (b) The second NCRD Plan (1968). Source: Nakabayashi (1983: 16-17). (c) Highway network plan under the second NCRD Plan (1967). Source: Kawakami (1990: 32). 
The second NCRD Plan proposed a metropolitan traffic system that would connect the Suburban Development Zone, the New City Development Area, and the Existing Urbanized Area of central Tokyo and called for a highway network consisting of several ring roads within the Capital Region and the Tokyo Bay road. To support the New City Development Areas, the Northern Kanto Intercity Highway - extending from Mito city in Ibaraki to Takasaki city in Gunma - was proposed.

Under the second NCRD Plan, the 1919 City Planning Law was abolished and a new City Planning Law (shin toshi keikaku hô) enacted in 1968 to implement planned urban development and avoid sprawl (see Chapters 2 and 5). The law attempted to control urban sprawl by creating two new forms of zoning: the designation of an Urbanization Promotion Zone (shigaika kuiki) and Urbanization Control Zone (shigaika chôsei kuiki) within the City Planning Area, and a detailed zoning system of land-use regulation in the Urbanization Promotion Zone. Under the new law, these zoning regulations were established by prefecture, based on recommendations from local governments. According to the zoning regulation system, each local government had its own city planning administration responsible for granting permits for buildings and urban development. This system was only partially successful at containing urban sprawl: while it could control the small-scale urban development and the construction of small, densely packed housing, it was not effective in the area of large-scale urban development - for example, in the Suburban Development Zone, which was transformed into a mosaic of numerous small-scale residential developments without regional infrastructures. Because the pressure for residential development continued to be strong, progress in regional infrastructure development was delayed, as funds inevitably ran short.

Urban development progressed, especially in the suburban areas of the metropolis. The estimated population under the second NCRD Plan was projected at 33.1 million by 1975, an increase of about 6.1 million from 1965. The actual population in 1975 reached 33.62 million in the Capital Region and 25.56 million in the Tokyo metropolitan area (Tokyo, Kanagawa, Saitama, and Chiba), which mainly consists of the Existing Urbanized Area and the Suburban Development Areas. While the population of the Existing Urbanized Area began to decrease, the Suburban Development Area was the most important area for the growth not only of the National Capital Region but also of the Japanese economy. During this period, Tama New Town in Tokyo, Kohoku New Town in Yokohama, and Chiba New Town began to be developed as large-scale bedroom communities in the Suburban Development Area. Tsukuba University and Science City also emerged, for the deconcentration of capital functions from the Existing Urbanized Area to the New City Development Area. Tokyo Educational University was demolished and Tsukuba University was established in the Tsukuba New City Development Area. Many national institutions, such as the Institute of Architecture and the Institute of Civil Engineering, were removed from the Existing Urbanized Area to the New City Development Area. 


\section{The third NCRD Plan: from manufacturing to service- oriented industries}

The Japanese economy grew exponentially from the latter half of the 1950s to the early 1970s. Then, in 1973, the oil shock struck. As a result, the economic growth of the nation slowed down dramatically, as did the rapid metropolitanization of the capital region. An additional outcome of this crisis was that the economy of Tokyo, as was occurring elsewhere, began to move from manufacturing-based to service-oriented industries.

The third NCRD Plan (dai sanji shutoken seibi kihon keikaku), a revision to the second plan, appeared in 1976. Projecting a target population for the Capital Region of 38 million by 1985, it kept the designations of Existing Urbanized Area, Suburban Development Zone, and New City Development Area (Tokyo Metropolitan Government 1978: 4-9).

Under the third NCRD Plan, the key concept of development in the Capital Region began to shift focus, from the deconcentration of manufacturing industries and the growth of industrial satellite cities to resolving the issue of concentration of new urban functions in central Tokyo. The headquarters of new and growing companies were moving their operations to Tokyo from all over the country for business opportunities in an increasingly information-oriented society. This trend prompted the service industries to grow rapidly in Tokyo. Their concentration in Tokyo resulted in a new hierarchy of Japanese cities - with functional polarization producing an urban system that established Tokyo's primacy over the other metropolises.

The focus of the Third Comprehensive National Development Plan of 1977 (dai sanji zenkoku sôgo kaihatsu keikaku or sanzensô) shifted from the metropolis versus the periphery to Tokyo versus the rest of Japan. The issue now was how to deconcentrate or decentralize these new urban functions from the center of Tokyo and spread them out into other metropolises nationwide and into the satellite cores of the Suburban Development Zone in the National Capital Region.

The third NCRD Plan put forward the concept of two sub-regions within the Capital Region: the Tokyo Metropolitan Area, combining the Existing Urbanized Area and the Suburban Development Area; and the Peripheral Zone in which the National Capital Development Areas were located. For the Tokyo Metropolitan Area, the plan proposed the construction of five sub-centers in the Tokyo Metropolitan Area, each of which would be designated a "Business Node" (gyômu kaku toshi) and would function as a business and commercial subcenter. These would share the power of the central business districts of Tokyo. The proposed Business Nodes included Yokohama and Kawasaki in Kanagawa prefecture; Hachiôji and Tachikawa in Tokyo prefecture; Urawa and Ômiya in Saitama prefecture; Tsuchiura and the Tsukuba Science City in Ibaraki prefecture; and Chiba in Chiba prefecture. In addition, a "cross-border" network was proposed that would connect the Business Nodes and the Central Business District (CBD) of Tokyo. Such a network would be changed to lead to the construction of a central ring road (kenô dô) and a Tokyo Bay ring road (Tôkyô wan kanjô dôro) (Kawakami 1990: 16-17) (Figure 3.9). 



New city development area

-..- Prefectural border

Suburban green space conservation area

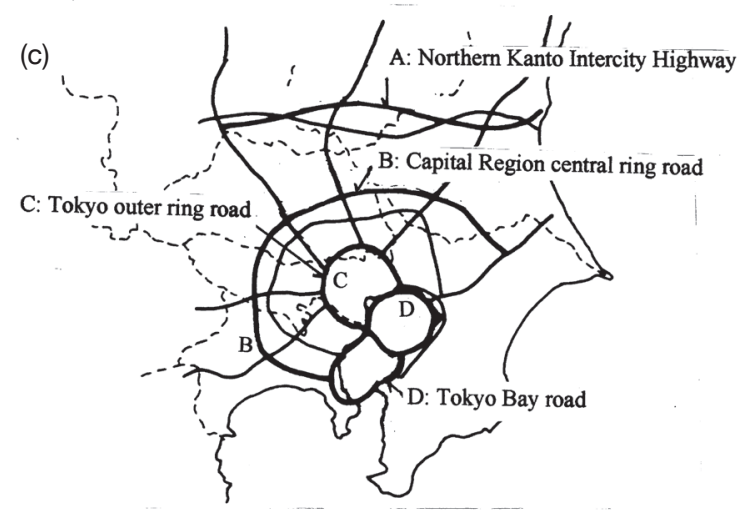

Figure 3.9 (a) The changing concept of metropolitan structure under the third NCRD Plan: from unipolar to multipolar (1975). Source: Kokudo chô (1990). (b) The third NCRD Plan (1976). Source: Kokudo chô (1990). (c) Highway network plan under the third NCRD Plan (1975). Source: Kawakami (1990: 17, 32). 


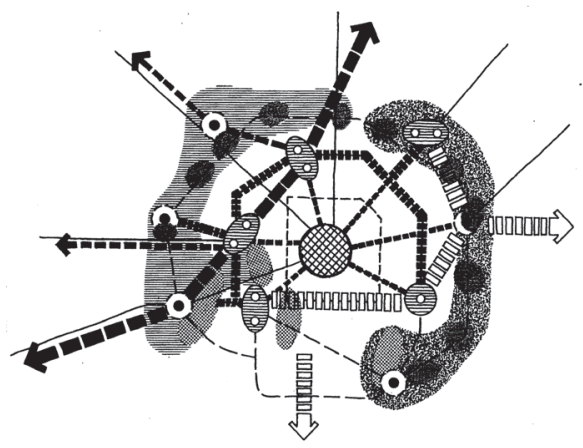

Center-core of Tokyo

-umu. Corridor connecting between Nuclear Business Cities and the परण Expansion of Internationalization Center-core of Tokyo

Figure 3.10 Conceptual draft plan for Capital Region Renewal Plan (1984). Source: Kawakami (1990: 18).

(a)
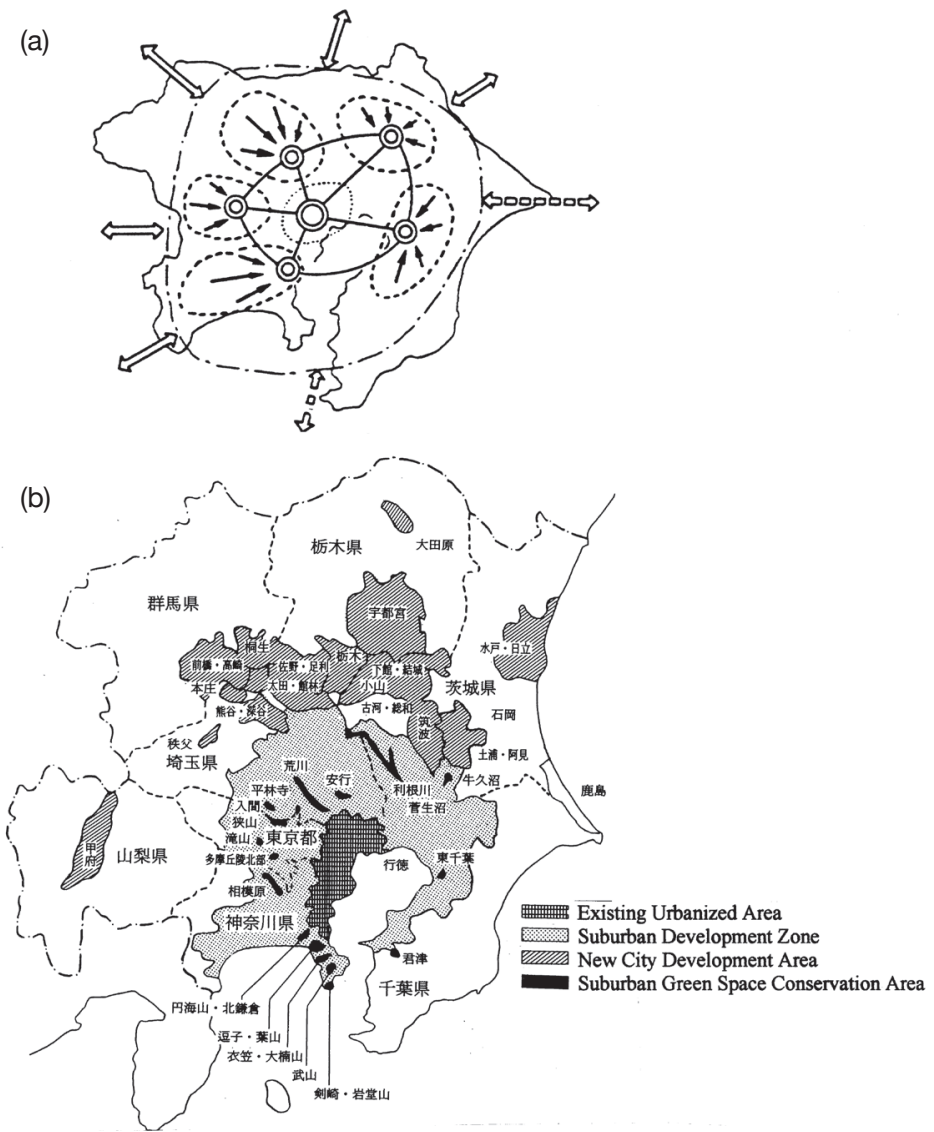

Figure 3.11 (a) Conceptual drawing of the fourth NCRD Plan (1986): concentrated deconcentration concept for the Capital Region with a multinuclear subregion. Source: Kokudo chô $(1996: 98,101)$. (b) The fourth NCRD Plan (1986). 
In the end, the Business Node concept never materialized, despite the growth in computer networks, internationalization, and the rise of the service industries. In the 1980s, the National Land Agency (Kokudo chô) conducted studies on the renewal strategy for the National Capital Region. The agency announced its Conceptual Draft Plan for Capital Region Development (Tôkyô daitoshi ken kinô tenkai zu) in 1984 (Figure 3.10). In this draft plan, the Business Nodes were designated as the core of a future self-sufficient urban sub-region. The draft plan led to the fourth NCRD Plan (Dai yon ji shutoken seibi kihon keikaku), announced in 1986 (Kawakami 1990: 18) (Figure 3.11a).

\section{A comparison of the concepts of the Fourth Comprehensive National Development Plan, the fourth NCRD Plan, and the Long-term Plan for the Tokyo Metropolis}

At the national level, in the Fourth Comprehensive National Development Plan of 1986, designated according to the Comprehensive National Development Law (zenkoku sôgô kaihatsu keikaku hô) promulgated in 1950, the primary task was the correction of Tokyo's unipolar growth. Its proposed goal was to create a multipolar (or polycentric) network. In 1988, a new National Development Law for a Multipolar Structure (takyoku bunsan gata kokudo keisei hô) was legislated in order to move from a unipolar to a multipolar structure at the national level. This law aimed to advance the development of business centers in major cities throughout Japan instead of industrial parks development. While Japan's industrial structure was becoming more service-oriented, Tokyo's one-sided development was a severe problem, the resolution of which would set a precedent for every other Japanese city, including Nagoya and Osaka.

At the Capital Region level under the Fourth Comprehensive National Development Plan, the fourth NCRD Plan was announced in 1986. This plan divided the capital region into two zones: the Tokyo Metropolitan Region, consisting of the Existing Urbanized Area and Suburban Development Zone; and a Peripheral Zone in which the satellite cities were designated as New City Development Areas. In the fourth plan, the construction of Business Nodes was a major goal of the development of the Suburban Development Zone as an extension of the existing cities, most of which were designated as industrial satellite cities in the previous NCRD plan. A special feature of the fourth plan was a proposed new urban structure for the Tokyo Metropolitan Area to correct Tokyo's lopsided growth. Many Business Nodes and core cities were proposed for the development of the Suburban Development Zone and were intended to surround the Existing Urbanized Area. Such cities receiving urban functions from central Tokyo were designated in Tokyo, Kanagawa, Saitama, Chiba, and Ibaraki prefectures. It was anticipated that self-sufficient sub-regions, such as the commuting sphere, would grow surrounding each Business Node. If this plan succeeded, the unipolar structure of the Tokyo metropolitan area would be transformed into a doublelayered structure consisting of a basic layer (the downsized sphere of the Tokyo metropolitan area with the heart of Tokyo as the single pole) and five secondary 


\section{Nakabayashi}

layers (the self-sufficient sub-regions newly grown around each Business Node) (Figure 3.11b). According to the plan, by the target year of 2000, the population of the Tokyo Capital Region was projected to be 40.9 million (Kokudo chô 1990: 94-111).

At the local government level, the TMG designated the first Long-Term Plan for the Tokyo Metropolis (Tôkyô-to chôki sôgô keikaku) in 1982. This plan, initiated by Tokyo Governor Suzuki Shun-ichi, consisted of two parts: a basic conceptual plan and a 10-year operational plan, and was revised periodically. The conceptual goal of this plan was to implement the multipolar structure of central Tokyo to promote a network of business centers in the Existing Urbanized Area of Tokyo. Its major goal was the creation of sub-centers (fuku toshin) that included Shinjuku, Shibuya, Ikebukuro, Ueno-Asakusa, Kameido-Kinshicho, Ôsaki, and the Seaside Center (rinkai fuku toshin) in the Existing Urbanized Area and would share various urban functions with central Tokyo (including Marunouchi, Ôtemachi, Ginza, Nihonbashi, Kasumigaseki, Toranomon, and other areas) (Tokyo Metropolitan Government 1994: 92-3). Not only a multinodal structure consisting of seven sub-centers in the ward area (as the Existing Urbanized Area), but also five core cities in the Tama area (Tama no shin) - Kichijôji, Tachikawa, Hachiôji, Tamacenter, and Machida - as a Suburban Development Zone of Tokyo, were proposed as a basic conceptual plan for Tokyo in the twenty-first century. It was clear in this plan that the Tokyo prefecture did not want urban functions moved from the Existing Urbanized Area of central Tokyo to the Suburban Development Zone in neighboring prefectures. In 1997, Tokyo's new governor, Aoshima Yukio, announced the new Development Plan for Resident-Friendly Tokyo (seikatsu toshi Tôkyô kôsô). Under this new plan, a concept of the deconcentration of urban functions centralized in the territory of the Tokyo prefecture took the place of the previous plan. Representing the TMG's effort to correct its lopsided structure in which urban functions were concentrated in the center of Tokyo, this concept for the centralized deconcentration of Tokyo entailed shifting urban functions to the surrounding secondary centers and Tama's core cities in the Tama suburban area belonging to the Tokyo prefecture. With this idea it is clear that the TMG rejected the distribution of urban functions outside Tokyo. This planning concept stood in direct opposition to the notion of Business Nodes, as laid out in the fourth NCRD Plan (Tokyo Metropolitan Government 1990: 3-15, 1998a: 26) (Figure 3.12).

In the second half of the 1980s and most of the 1990s, the three different levels of deconcentration policies were adopted to ameliorate the unipolar urban structure of the capital region. First, on the national level, the model of a multipolar national structure was promoted by the relocation of central urban functions from Tokyo to the other major cities in accordance with the Fourth Comprehensive National Development Plan. This is a deconcentration policy. Second, on the Capital Region level, the model of a multipolar metropolitan structure built in five Business Nodes as self-contained sub-regions independent of each other was advanced by removing urban functions from central Tokyo to the Business Nodes according to the NCRD Plan. Third, on the level of the Tokyo prefecture, the multinodal structure with a network consisting of a center, seven secondary centers, and 


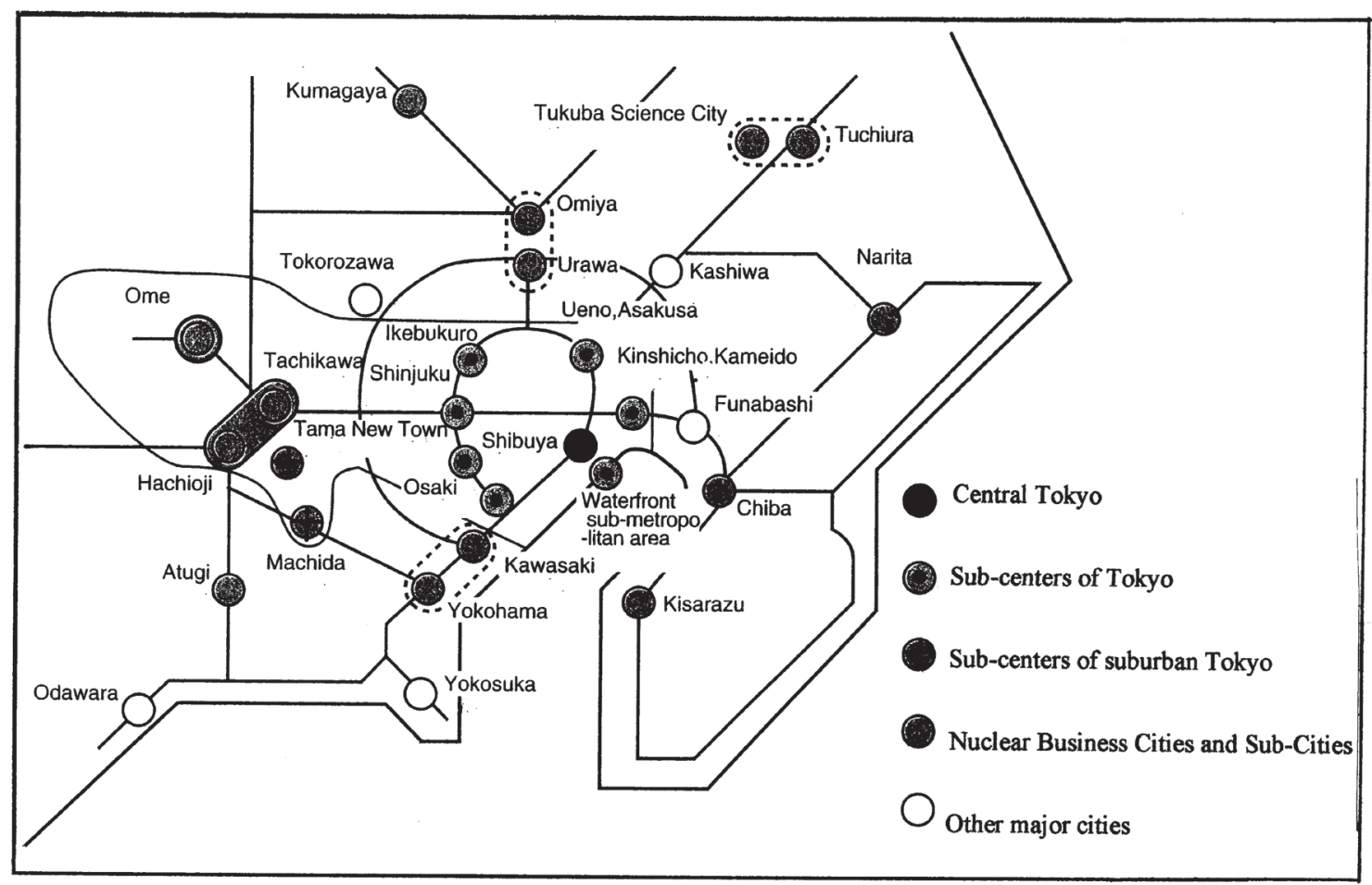

Figure 3.12 Spatial relationship between the multipolar structure of the fourth NCRD Plan (1986) and the creation of sub-centers of the Long-term Plan for the Tokyo Metropolis (1994). Source: Tokyo Metropolitan Government (1998a: 26). 
many core centers was promoted by the Long-term Plan for the Tokyo Metropolis. This is a policy of national concentration and regional deconcentration.

\section{The effect of the fourth NCRD Plan and implementation of the fifth NCRD Plan: toward cross-border relationships among prefectures and cities for the creation of a structure of centralized deconcentration}

The fourth NCRD Plan materialized during the excesses of the Japanese economic bubble in the late 1980s. In the middle of the 1980s, against a backdrop of internationalization, the growth of information-based businesses, and the restructuring of Japanese industry from industrial to tertiary, the National Land Agency reported that more than twice the existing amount of office space would be needed in the Tokyo ward area. The report prompted many business-center urban redevelopment projects to supply quantities of office space in central Tokyo. This urban redevelopment boom accelerated both a steep increase in land prices and a decrease in the population of central Tokyo (Tokyo Metropolitan Government 1998b: 5-12).

The draft plans for a development of Business Nodes were produced during this period. However, after the collapse of the bubble economy in the early 1990s, the trend toward concentration in central Tokyo appeared to slow down, as the decrease in population also slowed and land prices declined.

The key issue to be considered in analyzing the fourth NCRD Plan is whether or not the development of Business Nodes was successful. The developments were implemented in accordance with the Act for Promotion of Development based on a Multipolar National Structure (takyoku bunsan kokudo keisei hô). The Chiba Business Node was designated first in 1991, followed by Urawa-Omiya in Saitama prefecture in 1992, Tsuchiura-Tsukuba in Ibaraki prefecture and Yokohama in Kanagawa prefecture in 1993, Hachioji and Tachikawa cities in Tokyo prefecture in 1995, and Kawasaki in Kanagawa prefecture in 1997.

The details of all of these development projects are very similar. Each plan stipulates the construction of an exhibition hall; international convention center; commercial complex and shopping malls; cultural and entertainment facilities such as museums and theaters; hotels; office space; condominiums and apartments; and open spaces and plaza-style parks. The situation in Tachikawa city and Hachioji city was somewhat different, however, since the centers of both cities are rather small. These development projects were not part of the Long-term Plan of the Tokyo Metropolis. In addition, these developments are hampered by the severe financial constraints and the drawn-out economic recession of the postbubble period.

The fifth NCRD Plan (Dai goji shutoken seibi kihon keikaku) was announced in 1998. There were five major objectives for the fifth NCRD Plan: the completion of Business Nodes accompanied by the construction of a ring road linking the Business Nodes and sub-centers; the renewal and expansion of residential functions in the central Tokyo ward area along with the effective allocation of 
urban functions to the Business Nodes; the creation of space for housing in central Tokyo to offset the pressure of office and commercial development; the improvement of infrastructure, such as roads and parks; and the upgrading of international transportation and information systems, along with the establishment of telecommunications systems befitting Tokyo as a world city.

The fifth NCRD Plan set 2015 as the target year for its goals. In contrast to the previous plan, the fifth version projects a decline in population during the life of the plan - not only in Japan as a whole but also specifically within the Capital Region. The decrease in population is anticipated to be accompanied by a rise in the average age of citizens in the Capital Region and a lower rate of economic growth, which causes less incoming migration from other areas in Japan (Kokudo chô 1999: 264-307).

In light of these expectations, the Fifth Plan lays out the following social objectives for the region: the facilitating of opportunities for economic, social, and cultural activity in the Capital Region in order to increase the productivity of Japan; the freeing of social and geographical constraints to enable all citizens to participate in various social activities; the creation of an ecologically sound and sustainable society and the improvement of the safety and convenience of the urban environment; and the creation of a Capital Region more resistant to natural disasters such as earthquakes and with a durable infrastructure to pass on to future generations.

The fifth NCRD Plan prescribed the general direction for the new structure of the Capital Region in the twenty-first century as a deconcentrated networking structure. The plan divided the Capital Region conceptually into two new zones: the Tokyo Metropolitan Zone (Tôkyô dai toshi ken), within a 60-kilometer radius of the center, and the Peripheral Zone, beyond the 60-kilometer radius. The Peripheral Zone consists of four zones, including the Northern Kanto Zone (kita kantô renkei toshi ken), Eastern Kanto Zone (higashi kantô renkei toshi ken), Western Inland Zone (seibu nairiku renkei toshi ken), and Islands Zone (tôsho ken) (Kokudo chô 1999: Appendices 1-8). Within these zones, the plan delineates four kinds of nodal cities: central Tokyo (Tôkyô toshin) and Business Nodes in the Tokyo metropolitan area, core cities (kôiiki renkei kyoten toshi) for the collaboration between neighboring sub-regions in the capital, and sub-cities (chiiki renkei kyoten toshi) for the collaboration between cities and each sub-region in the Peripheral Zone (Figure 3.13).

In the above hierarchical structure of two zones and four nodal cities, the core city and sub-city are new planning concepts for a new kind of collaboration. The characteristic of the relationship of both these entities with sub-regions and cities can be characterized as a "cross-border" collaboration, in which urban functions are shared by each city and each sub-region. For example, a large-scale commercial development may be implemented in one city and cultural facilities in another city.

For the implementation of the above concept, the Tokyo metropolitan area encompasses an area within a 60-kilometer radius that legally consists of the Existing Urbanized Area and the Suburban Development Zone, just as under the 


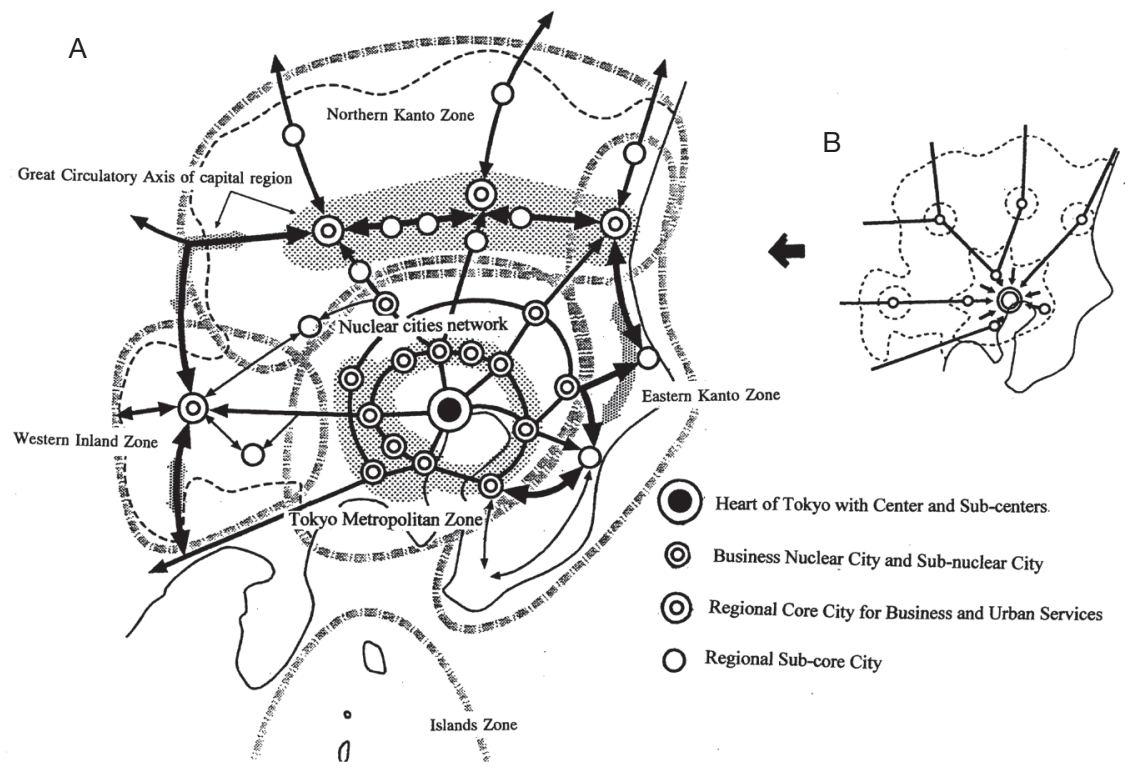

Figure 3.13 Conceptual drawing of the fifth NCRD Plan (1998). Source: Kokudo chô (1999: Appendix 8). (a) Deconcentrated network structure of the future Capital Region. (b) Unipolar structure of traditional Tokyo.

fourth NCRD Plan. In reality, the Tokyo metropolitan area resembles the area within commuting distance of central Tokyo, and can be divided into two subzones with different planning objectives: the Existing Urbanized Area including central Tokyo within a 20-kilometer radius, and the Suburban Development Area, encompassing the area surrounding the Existing Urbanized Area within a radius of 20-60 kilometers. The main planning objectives for this area are not only the community's revitalization but also the upgrading of residential areas, particularly those that contain densely packed wooden houses (mokuzô jûtaku misshû shigai chi; the most vulnerable to earthquakes), and the promotion of effective use of vacant or underutilized lands intended for office buildings in the bubble-economy period.

Within the Suburban Development Zone, the main goal of the development plan is the continued creation of Business Nodes and the network of connecting roads. These cities have included Yokohama, Kawasaki, Atsugi, and Sagamihara in Kanagawa prefecture; Machida, Tama-center, Hachiôji, Tachikawa, and Ôme in Tokyo prefecture; Kawagoe, Kumagai, Urawa, Ômiya, Kasukabe, and Koshigaya in Saitama prefecture; Tsuchiura, Tsukuba, and Ushiku in Ibaraki prefecture; and Kashiwa, Narita, Chiba, and Kisarazu in Chiba prefecture. The number of Business Nodes designated under the fifth NCRD Plan is three times greater than in the fourth plan and includes formerly designated sub-centers.

Under the fifth NCRD Plan, new projects have been added. One is encouraging 
the growth of core cities as new business nodes and sub-centers in the Peripheral Zone by upgrading the quality of life, increased business opportunities and more urban functions. The plan anticipates that the core cities will become a nodal point for the cross-border collaboration in this area.

Another project is an infrastructural development related to core cities and sub-centers in cross-border collaborations. Called the Outer Ring Expressway of the Capital Region, this network of roads links core cities in the Capital Region. Specifically, the fifth plan's conceptual direction for development in the northern Kanto Zone, western Inland Zone, and eastern Kanto Zone is embodied in this project, which is expected to link every core city in three zones in the future and promote growth and exchange.

On the prefectural level, in 2000 the Tokyo Metropolitan Government announced a new political vision and designated a long-term plan under the direction of Governor Ishihara Shintarô. In accordance with this long-term plan, a master plan for new regional development, called the Development Plan for Tokyo Megalopolis was announced in 2001 (Tokyo Metropolitan Government 2001). The underlying concepts of this plan, which has a target year of 2050, are very similar to those of the fifth NCRD Plan, with the exception of a separate urban-development master plan produced by the Tokyo Metropolitan Government (Figure 3.14). Unique to the TMG, it includes concepts such as sustainability, ecological symbiosis between urbanization and nature, networks of transition and information in the Tokyo Metropolis, growth of core areas and the core city, world city development amid internationalization, safe urban life, cross-border collaboration with neighboring cities, and public participation. Usually a local govern-

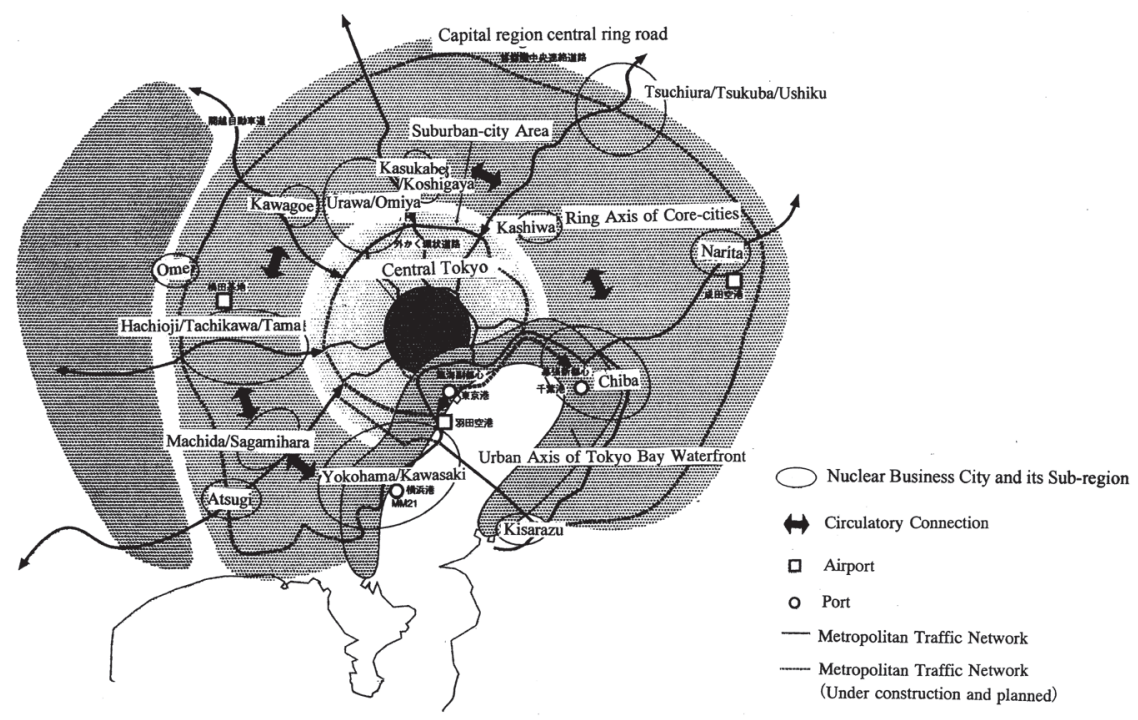

Figure 3.14 Conceptual drawing for the Tokyo Megalopolis in 2050, proposed by the Tokyo Metropolitan Government (2001). Source: Tokyo Metropolitan Government (2001: 22). 
ment drafts a plan for only its own territory, not that of neighboring governments, so as not to interfere with their autonomy. The new TMG plan, however, includes as a target area not only Tokyo prefecture but also the neighboring prefectures of Kanagawa, Saitama, and Chiba. The first "cross-border" plan produced by a local government, it was made possible by the existence of the Convention of Eight Prefectures and Designated Cities (kenshi kyôgikai), which - composed of the four prefectures of Tokyo, Kanagawa, Saitama, and Chiba and the four "special designated" cities of Yokohama, Kawasaki, Saitama, and Chiba - facilitated discussion, coordination, and collaboration (Tokyo Metropolitan Government 2001) (concerning Governor Ishihara, see Chapter 8).

\section{Conclusion: collaboration and cross-border relationships in the Capital Region of the twenty-first century}

The 1924 International Conference on City Planning held in Amsterdam clarified that the regional planning system under the cross-border relationship of local governments was a very important issue for the metropolitan area, which consisted of many local governments. The national government announced development plans for the Kanto region several times before World War II and endeavored to implement a succession of such plans nationwide, as well as three metropolitan plans, during the second half of the twentieth century.

Presently, the fundamental concepts underlying the various plans for the Capital Region differ from one another. The Comprehensive National Development Plan was based on the idea of a decentralization of urban functions from the capital, Tokyo, to other regions. Under the NCRD Plans managed by the national government, there has been a centralized deconcentration of urban functions from the heart of Tokyo to the business nodes in the Suburban Development Zone and to the core cities in the Peripheral Zone, accompanied by collaboration and crossborder exchange within each local government in the Capital Region.

The Tokyo Metropolitan Government's current urban development master plan represents a centralized deconcentration in the territory of Tokyo prefecture. The TMG's goal is to continue as the capital of Japan, and thus to deconcentrate urban functions from the central part of Tokyo to secondary centers in the heart of the capital and to Tama's core centers in Tokyo's suburban area, not beyond Tokyo prefecture. At the same time, the TMG has begun to discuss and to collaborate with neighboring governments in a cross-border approach.

In the early twenty-first century, all the plans produced at the national, capital region, and prefectural levels feature key terms such as "deconcentration," "crossborder," and "collaboration," aimed at developing and improving the Capital Region and the Tokyo metropolitan area in the face of an aging and shrinking population and the slow growth of the Japanese economy. Nevertheless, the National Capital Region Development Law does not yet provide a complete system for the administration of metropolitan planning. To achieve the goals of the NCRD Plans on cross-border collaboration with neighboring prefectures and cities along with decentralization of governmental power, it is necessary to establish a new system 
of metropolitan administration based on cross-border relationships for collaboration with each government.

It is noteworthy that in the fifth NCRD Plan the cities of Machida and Sagamihara are designated as a group of business nodes, demonstrating the first case of crossborder collaboration between Tokyo and Kanagawa prefectures. In addition, four zones defined in the fifth NCRD Plan are established as cross-border zones among adjacent prefectures, so as to grow various cross-border relationships.

The concept of both the cross-border relationship and collaboration between adjacent prefectures and cities is key to developing the new Capital Region in the twenty-first century. This will reinforce the vitality of the Capital Region, which is necessary for the sustainable growth of the Japan of the future. In the twentieth century, the expansion of Tokyo was the most important issue to be resolved in both national policy and Capital Region planning in order to lessen the gap between Tokyo and the other metropolises and local regions. However, it is recognized that the growth of Tokyo leads the economic growth of the Japanese economy in the twenty-first century. In the post-bubble Tokyo of today, there are many urban redevelopment projects that operate under a national policy of deregulation and urban revitalization, not only in the center and sub-centers of Tokyo but also in other areas, such as Roppongi, Aoyama, Shinbashi, and Shinagawa. For example, a private company directed the creation of Roppongi Hills Projects, a large-scale construction project in Tokyo, which includes a museum, hotel, offices, and shops. In Shinbashi and Shinagawa, large vacant sites of former railway yards are redeveloping as business parks composed of high-rise office buildings combined with hotels, recreation areas, retail shops, and residences.

The coming era will be one of competition among urban governments to attract both residents and urban functions against a backdrop of depopulation and economic slowdown. While local governments are gaining more administrative authority, they must collaborate in order to ensure urban growth for all. The means by which this can occur most efficiently is an administrative apparatus for cross-border collaboration operated independently by prefectures and cities under a model of decentralized authority.

\section{References}

City Planning Institute of Japan (ed.) (1988) Centenary of Modern City Planning and Its Perspective, Tokyo: City Planning Institute of Japan.

Ishida Yorifusa (1987) Nihon kindai toshi keikaku no hyakunen (A century of modern city planning in Japan), Tokyo: Jichitai Kenkyûjo.

Ishikawa Hideaki (1993a, originally published 1946) "Tokyo fukko toshi keikaku ron" (Theory of Tokyo's reconstruction plan), in City Planning Institute of Japan (ed.) Ishikawa Hideaki toshi keikaku ron shû (Papers on City Planning of Dr. Ishikawa Hideaki), Tokyo: Shôkokusha, pp. 703-47.

_ (1993b, originally published 1946) "Toshi fukko no genri to jissai" (Principles and reality of urban reconstruction), in City Planning Institute of Japan (ed.) Ishikawa Hideaki toshi keikaku ron shû (Papers on City Planning of Dr. Ishikawa Hideaki), Tokyo: Shôkokusha, pp. 588-649. 


\section{Nakabayashi}

Kawakami Hidemitsu (1990) Kyodai toshi Tôkyô no keikaku ron (Planning of the Tokyo Megalopolis), Tokyo: Shôkokusha.

Kokudo chô (National Land Agency of Japan) (1990) Shutoken hakusho 1990 (White paper on National Capital Region 1990), Tokyo: Kokudo chô.

_(1996) Shutoken hakusho 1996 (White paper on National Capital Region 1996), Tokyo: Kokudo chô.

-(1999) Dai 5 ji shutoken kihon keikaku (The fifth National Capital Region Development Plan), Tokyo: Kokudo chô.

Nakabayashi Itsuki (1980) "Postwar Growth of Tokyo and the Architectonic Change of its Built-up Area," Geographical Reports of Tokyo Metropolitan University, Department of Geography, Tokyo Metropolitan University, 14-15: 111-39.

_(1983) "Midori no chiiki keikaku - Tôkyô dai toshi-chiiki ni okeru ryokuchi keikaku no keihu" (Regional planning for green space - history of green space planning in the Tokyo Metropolitan Area), Machizukuri kenkyû (Research on Community Building) 18: $10-20$.

Tokyo Metropolitan Government (1978) Planning of Tokyo, 1978, Tokyo: Tokyo Metropolitan Government.

- (1990) Planning of Tokyo, 1990, Tokyo: Tokyo Metropolitan Government.

— (1994) A Hundred Years of Tokyo City Planning, Tokyo: Tokyo Metropolitan Government.

(1998a) Urban White Paper on Tokyo Metropolis 1998, Tokyo: Tokyo Metropolitan Government.

- (1998b) Planning of Tokyo, 1998, Tokyo: Tokyo Metropolitan Government.

-(2001) Tôkyô no atarashii tosh zukuri bijon - Toshi saisei he no tashikana michi suji (A new vision for Tokyo's city planning: the route for urban regeneration of Tokyo), Tokyo: Tokyo Metropolitan Government. 


\title{
4 Financial stress in the Japanese local public sector in the 1990s
}

\author{
Situation, structural reasons, solutions
}

\author{
Alain Schebath
}

The issue of local autonomy, although written into the Japanese constitution (Articles 92-95 of Chapter 8), remains a controversial matter, especially in the arena of financing. Public services in Japan are primarily the purview of municipalities and prefectures, which account for some two-thirds of public spending on such services but only receive one-third of all public revenues. This difference results in an important shift of revenue-generating from the national level to local communities that bears very little resemblance to the systems in place in other countries. The issue raised is that of local revenues versus taxation from national subsidies in regard to the borrowing capacity of local communities. Moreover, the financial issue also means that the state necessarily intrudes in the local sphere. Prefectures and municipalities are responsible for a wide range of services, mainly public works, including town planning, transportation, and industrial and educational infrastructure. The decentralization law enacted in 2000 was aimed at reforming the old system of responsibilities delegated to local communities under the control of ministries, with the goal of moving toward a redistribution of powers based on mutual cooperation rather than subordination (see also Chapters 2 and 8). Changes also occurred in local financing but do not appear to have kept pace with the current financial difficulties of Japanese communities.

At the end of the 1990s, newspaper and television reports portrayed the financial situation of the Japanese local public sector as a state of crisis. Since the collapse of the "bubble" economy that occurred at the beginning of the decade, the Japanese economy has taken more than 10 years to recover.

According to the media, the country's financial crisis (Japan's public debt represented approximately 150 percent of the GDP in 2004) can be traced to public-works projects realized during the bubble era and a neglect of financial restructuring, as well as a lack of awareness. The public sector previously experienced two periods of financial trauma, one after World War II and the other in the 1970 s as a result of the oil shock, but these were not as severe as the situation today. After examining a number of indicators that demonstrate the extent of the local public sector's current financial crisis, this essay will outline its underlying causes and analyze the solutions proposed by the national and local governments as well as by experts. 


\section{Schebath}

\section{Financial issues for Japanese local communities in the 1990s and early 2000s}

Financial stress in the Japanese local public sector can be charted through a series of comparative rates that show the actual deterioration of the local financial picture. One of the major trends that can be observed is a decrease in revenue from local taxes in the 1990s, which has leveled off at the beginning of the 2000s. As in European countries, Japanese municipalities and prefectures levy taxes whose imposition is governed by national law. While rates and tax bases are fixed by the national Diet, local communities can change these rates within a small range (Wada et al. 1999). ${ }^{1}$

Even if the 2000 law on decentralization introduced a measure of financial reform by permitting municipalities and prefectures the ability to generate new taxes outside legal standards as well as the freedom to establish rates for local taxes, the main sources for local revenues have scarcely changed and their position has rarely evolved in the local budget.

Of the different kinds of local taxes, the main ones are the resident tax (on individuals and corporations), business tax, and fixed-assets tax (Schebath 1999: 156-7). The sources for local revenues in 2002 included local taxes (36 percent), global grant (20 percent), central government disbursements (financial transfers from ministries) (14 percent), borrowing (14 percent), miscellaneous (13 percent), charges and fees ( 3 percent). While local taxes represent the largest share of the revenues, they did not really experience favorable growth overall during the 1990s. Representing 45 percent of the total revenues in 1990, local taxes decreased to a total of 35 percent in 1995 and since that year have stabilized at between 35 to 37 percent (Figure 4.1).

As the local tax base is primarily dependent on business profits, local tax monies naturally decreased after the collapse of the "bubble" in 1990. Fluctuation in taxable revenues has had a strong negative impact on the financial status of Japanese local communities, especially in the intergovernmental relationships (between national and local) in terms of local autonomy (Kanazawa 1997: 39).

Another trend is the increase from 1995 to 2000 in the percentage of local revenues derived from the global grant (the portion of national tax monies allocated to local communities). But, as is the case with local taxes, this growth is linked to the decline in budget expenditures. If central government disbursements are added to the global grant representing financial transfers from the national government to local communities, the total amount actually decreased in $2002-34.8$ percent of the revenues in 2001 and 33.6 percent in 2002.

In order to cope with the decline of revenues from local taxes, starting in the early 1990s, local communities began to issue more local bonds than previously, with the approval of the national government. The share of local revenues represented by bonds rose from 8 percent in 1990 to 17 percent in 1995, falling to 11 percent in 2000 and then increasing again, to 14 percent in 2002. These figures show that recently loans have been the main means for local communities to alleviate their revenue problems. Nevertheless, as many municipalities and prefectures find themselves in a worsening financial situation, it will be more dif- 


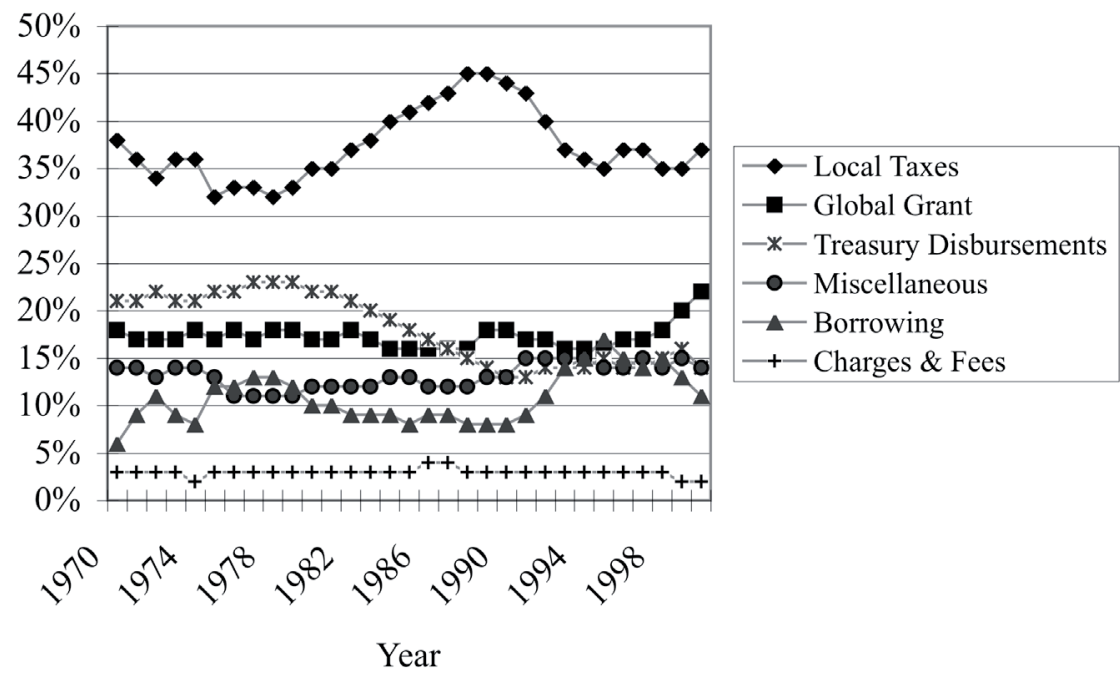

Figure 4.1 Evolution of the sources of revenues of the Japanese prefectures and municipalities from 1970 to 2000. Source: Jichishô (Ministry of Local Affairs) (1999).

ficult for them to receive permission from central government to issue local bonds (Kaneko 1998). Moreover, some local communities, knowing that they will not be able to repay their loans in the future if they do not have a steady, stable revenue stream, are eager to reduce the use of bonds to finance public works.

The issuance of more bonds in the 1990s generated an increase in the total amount of local debt, which is revealed by many indicators. Among these has been a significant increase in the amount of debt carried by Japanese prefectures and municipalities, which, according to the data compiled by the Ministry of General Affairs (Sômushô), more than doubled during the 1990s. Table 4.1 presents the pattern of increase in local debt in trillions of yen from 1990 to 2004 together with the percentage of the gross national product (GNP) occupied by local debt.

Local debt is made up of three components: the largest consists of the bonds issued by local communities, which represented 70 percent of the total debt in 2002. Bonds for the financing of the global grant system and the debt carried by local public companies each represented 15 percent of the total, with significant increases in recent years. Therefore, even if prefectures and municipalities attempt to reduce the issuance of loans, the total amount of local debt could continue to grow. The first reason is that local public companies are facing deficits. One solution has been a proposal by the national government to privatize these companies, a risky undertaking - especially with the debt burden of public companies - that seems unlikely to occur. The second reason for an anticipated increase is that the national government, which normally finances the global grant system, is in a worse financial situation than the local communities. It is probable that loans will be used increasingly to finance this global grant (for an overview of the global grant, see Aoki 2001). 


\section{Schebath}

Table 4.1 Total amount of local debt and amount of local debt compared with the GNP

\begin{tabular}{lll}
\hline Year & Debt in trillions of yen & Debt as percentage of GNP \\
\hline 1990 & 67 & 15 \\
1991 & 70 & 15 \\
1992 & 79 & 17 \\
1993 & 91 & 21 \\
1994 & 106 & 25 \\
1995 & 125 & 27 \\
1996 & 139 & 29 \\
1997 & 150 & 31 \\
1998 & 163 & 33 \\
1999 & 174 & 35 \\
2000 & 182 & 37 \\
2001 & 190 & 38 \\
2002 & 195 & 39 \\
2003 & 199 & 39 \\
2004 & 204 & 40 \\
\hline
\end{tabular}

Source : Sômushô (Ministry of General Affairs) (2001, 2003, and 2004).

Local debt increased steadily from 1980 to 1990 but went up sharply after 1992. During the 1980s, the debt/GDP ratio decreased from 19 percent in 1982 to 15 percent in 1990. But the 1990s saw a major increase in the amount of local sector debt (Nomura 1999: 176). From 1990 to 2004, the growth of the debt exceeded 204 percent. The debt/GDP ratio has followed the same pattern, increasing from 15 percent in 1991 to more than 40 percent in 2004. The amount of the Japanese local debt in 2004 represented the equivalent of the entire GNP of the United Kingdom or France (at a rate of 1 euro per 125 yen).

Despite the fact that local communities have made an effort to reduce the issuance of local bonds, the amount of local debt continues to grow. A rule of thumb in public finance states that, whereas only a few years are need to incur debt, it takes a decade for local communities to regain their financial footing. Therefore one could extrapolate that, in a case of a decade's worth of debt increase, several decades of efforts are needed to attain financial stability.

With quickly mounting debt during the 1990s, Japanese prefectures and municipalities were forced to tighten bond redemption. Thus, the portion of the debt repayment within total expenditures increased from 8 percent in 1993 to 12 percent in 1999. It is this expense that experienced the strongest rates of growth in 1996 and 1997.

Another way to estimate the debt burden on the budget of local communities is to examine the percentage of their own revenues consumed by the debt repayment. Table 4.2 shows the share of interest and capital redemption per year compared with local revenues (local taxes and the global grant) for the entire Japanese local public sector. 
Table 4.2 Evolution of the ratio of annuity to local revenues

\begin{tabular}{ll}
\hline Year & Amount of annuity as percentage of local revenues \\
\hline 1992 & 11.2 \\
1993 & 11.9 \\
1994 & 12.6 \\
1995 & 13.3 \\
1996 & 14 \\
1997 & 15.2 \\
1998 & 16.4 \\
1999 & 17.2 \\
2000 & 17.7 \\
2001 & 18.4 \\
2002 & 19.2 \\
\hline
\end{tabular}

Source: Sômushô (Ministry of General Affairs) (2001, 2003, and 2004).

The increase in this ratio reveals the importance of the debt for local public finance. The Japanese national government indicates the limit of vigilance at 15 percent. The statistics of the Ministry of General Affairs show that the number of municipalities that have gone over this limit has increased sharply during the last decade. There were 1,065 municipalities over the limit in 1992, jumping to 2,005 in 1999. Out of 3,229 municipalities in 2001, 62 percent of them face a debt problem. The situation is even worse for the prefectures, with 85 percent of them in the red in 1999. The 2001 white paper on local public finance underscores what has become a clear tendency toward having more local communities bear the brunt of debt each year (Sômushô 2001: 33).

In the 1990s, Japanese local communities found themselves in an increasingly shaky financial position. As a result, it became more and more difficult for them to have available revenues with which to finance their own investments. Table 4.3 shows the increase in the mandatory burden rate, which takes into account mandatory expenditures compared with local revenues. Mandatory expenditures include personnel expenses, social-minimum expenses, and the debt annuity. Local revenues are made up of local taxes and funding from the global grant. The higher the rate of state-mandated expenses, the fewer funds are available for local communities to invest in their own projects. The data in the table reveal a significant increase in the rate of state-mandated expenses during the 1990s, meaning that the financial ability of local communities to invest shrank sharply. At the same time, local revenues did not increase as quickly as the expenditures, and in some years decreased, as, for example, in 1992 and 1994.

In 1999 and 2000 the rate of the mandatory burden decreased. The explanation for this sudden reversal is that personnel expenses began to be a smaller percentage of the total budget. Many prefectures and municipalities decided to implement plans to reduce the number of employees and the wages of local public servants. Nevertheless, in 1999, the figure of 75 percent of total budget required for manda- 


\section{Schebath}

Table 4.3 Ratio of mandatory burden borne by Japanese local communities

\begin{tabular}{ll}
\hline Year & Mandatory burden as percentage of local expenses \\
\hline 1990 & 70.2 \\
1991 & 71.3 \\
1992 & 74.8 \\
1993 & 79.4 \\
1994 & 84.1 \\
1995 & 84.7 \\
1996 & 84.8 \\
1997 & 87.4 \\
1998 & 89.4 \\
1999 & 87.5 \\
2000 & 86.4 \\
2001 & 87.5 \\
2002 & 90.3 \\
\hline
\end{tabular}

Source: Sômushô (Ministry of General Affairs) (2001, 2003, and 2004).

tory expenditure, generally recognized as a red flag, was still exceeded by more than 85 percent of Japanese local governments. Nevertheless, starting in 2001, the mandatory burden rate began to increase again, reaching 90.3 percent in 2002. In its 1999 report to the national Diet, the Ministry of Local Affairs indicated that the financial situation of the local public sector was becoming increasingly inflexible (Jichishô 1999: 28).

\section{The particular situation of metropolitan areas and urban prefectures}

The situation described above is much more problematic in the case of metropolitan areas and urban prefectures, especially Tokyo, Osaka, Aichi, and Kanagawa. These metropolitan entities faced acute financial difficulties in the 1990s because of a steep loss of revenues, which derive principally from taxes, and an increase in their mandatory expenditures.

In 1998, a special law consisting of measures intended to strengthen the financial reconstruction of the Japanese local public sector was enacted, with the aim of discouraging the issuance of local bonds. Deficits were foreseen in the budgets of the main urban prefectures (for instance, 1 trillion yen for Tokyo, 30 billion for Kanagawa and Aichi, and 17 billion for Osaka).

This perilous financial situation can be explained first by the fact that these metropolitan areas are more dependent on business taxes than any other Japanese prefectures. Accordingly, the percentage of the total tax revenues of metropolitan prefectures derived from taxes on businesses is almost double that of any other prefecture (20 percent and 11 percent respectively). Consequently these metropolitan communities have faced a tougher decrease of their own revenues after 
the beginning of the economic recession. Tokyo and Osaka were the most affected by these decreases. For instance Tokyo lost 1 trillion yen in tax revenues between 1989 and 1998 and Osaka lost close to 600 billion during the same time period.

Primarily in the case of Osaka and Kanagawa, mandatory expenses and expenses for infrastructure maintenance represent the major portion of the total expenditures of these prefectures. In 1997, in the four main prefectures 73 percent of their revenues went to these two types of expenditure, compared with 59.5 percent for all the other prefectures.

Consequently, the mandatory burden rate of the metropolitan prefectures is unfavorable, or even negative in the case of Osaka and Kanagawa (112 and 106 percent, respectively, in 1997). This situation explains the necessity of the 1998 law on financial reconstruction of Japanese local communities.

\section{Structural causes of financial problems in the Japanese local public sector}

There were a number of reasons for these dire financial difficulties. In the late 1990s, the press reported frequently on the danger of local communities going bankrupt (Pons 1998; Satô 1998). The decrease in revenues from business taxes was generally viewed in the framework of the Tokyo or Osaka metropolis (Aoyama 1998). In addition, the mass media claimed that the growth of the bond repayment requirements was a consequence of the huge debt of the Japanese local public sector, emphasizing the point that under such circumstances municipalities and prefectures had no ability to contribute to national plans to restore the economy (Shimizu, Tani, and Toyofuku 1998). For this crisis the media blamed the irrational behavior of the "bubble" period (1985-90), which was characterized by many overblown infrastructure projects (Pons 1998). Many local communities did not fully understand the level of financial risk involved in these projects. In order to fully understand the reasons that led the Japanese local public sector to the brink of bankruptcy, however, it is necessary to examine the underlying structural causes (Kanazawa 1999).

\section{Transformation of intergovernmental relationships}

During the 1980s, sweeping changes occurred in the redistribution of public services and activities between the national and local government levels. In 1983, the committee of financial adjustment, appointed by the government of Nakasone Yasuhiro, published a report focusing on two slogans: "from public to private sector" and "from national state to local public sector," both of which were linked to privatization and decentralization policies. Following the findings of the committee report, a transfer of administrative activities from the state to local communities took place over the next several years. For example, under a law passed in 1990, municipalities were given control of social and welfare services. However, this shift in authority was not accompanied by an equivalent transfer of revenues. 
Moreover, after introducing a set of fiscal measures, including the introduction of value added tax (VAT) and its subsequent rate increase, as well as the abolition of tax exemptions for some categories of residents, such as pensioners, the national government encountered opposition from the public in the 1990s and a decrease in consumption in 1997-8. Consequently the government changed its course and decreased income-tax rates. Local communities were then obliged to carry out the same policies and the residents' tax rates were thus reduced by a decision of the national government. Naturally, this move reduced revenues in the Japanese local public sector.

In addition, in the mid-1980s, the state government was focused on the reform of public finances on a national level and sharply reduced the funds to be transferred from the national budget to local ones (treasury disbursements). At that time, with economic growth generating a large gain in revenues, local communities could cope with such a decrease, but with the recession in the 1990s, as described above, they faced a loss of corporate tax revenues and the national government resisted increasing its funding to compensate for the shortfall.

In fact, beginning in the mid-1980s, the national government failed to secure stable financial revenues for prefectures and municipalities. Moreover, the state transferred to local communities the responsibility for more public services, which resulted in a heavier financial burden. This situation continued throughout the 1990s.

\section{The impact of a national policy of economic regulation}

Because they represent two-thirds of public expenditures, Japanese local governments are strongly affected by national economic policies. After the oil shock of the 1970s, during the 1980s and 1990s the national government tried to solve the problem of the rigidity of local public finances. To do so, it advocated reducing personnel expenses by cutting wages, freezing the number of civil servants, and contracting with private companies to realize public services more efficiently. On the other hand, public-works expenditures, considered flexible, were encouraged. Paralleling this, the question of public debt and the role of the public sector in the economy became an important issue. In relation to this policy of public-sector withdrawal accompanying privatization, and with the transfer of competencies following decentralization, the national government called on the local governments to intervene still further.

In this context, two important international events occurred. First, in 1985, with the Plaza Agreement, made between United States and Japan, the Japanese government had to accept a reevaluation of the yen. After the endaka (rise of the yen), the Japanese economy faced a small recession, which the national government tried to combat with an economic-revival policy using construction of public works, such as roads and bridges, as a tool.

In 1989, under pressure from the American government, which sought to lower its trade deficit with Japan, the Japanese government agreed to invest over a 10year period the amount of 630 trillion yen in public works to revive the Japanese domestic market. In both cases, the national government asked local communities 
to implement these policies. But whereas, during the euphoric period of the bubble, prefectures and municipalities had the financial resources to realize infrastructure projects, after the collapse of the bubble and a decrease in revenues, it was much more difficult for these communities to meet the central government's request.

Finally, in the early 1990s, public works became the cornerstone of the "daily life promotion plan" promulgated by the Miyazawa Kei-ichi government. The objectives of these measures were foremost to catch up with other industrialized nations in terms of social and cultural infrastructure, and also to serve as countermeasures against the economic crisis. In order to achieve these goals the national government chose to facilitate the approval of the issuance of local public bonds in the beginning of the 1990s, with the above-mentioned results. In spite of the remarkable size of the request from the central government, every local community was pleased to apply to the public works plan as all of them had infrastructure projects. It is clear that the financial costs were excessive, and this generated the financial crisis in the Japanese local public sector at the end of the 1990s.

\section{The failure of financial measures}

An examination of the local public sector during the last two decades reveals that it failed to adopt a viable policy of financial stability. Normally, during a growth period, local government focuses on loan repayments to reduce its debt, on augmenting its savings funds, and on trying to limit increasing its expenditures. During a recession, loan issuance should be restricted and local governments must use savings funds to avoid a too sharp decrease in expenditure so that the highest quality of public services is maintained. Obviously, the increase in public-works expenses did not permit the Japanese local governments to follow this course of action.

In addition, during 1996-7, the government of Hashimoto Ryûtarô made a grave error in timing in the implementation of its financial reconstruction policy. Expecting that economic growth would hold steady after the recovery of 1996 and focusing on the reduction of the public debt, the national government implemented a set of measures (an increase in VAT, and a strong retrenchment in public expenditures) that had a very negative impact on consumption, breaking the small wave of growth and leading the Japanese economy into its worst recession since World War II.

In spite of statements issued by the national government, public-works expenditures have not been so flexible in the medium or long term. There are two main reasons for this, the first being the importance of the public-works sector in the Japanese economy - accounting for 10.5 percent of employment and 18.5 percent of GNP in 1996, compared with only 7.1 percent and 11.4 percent, respectively, for the other member countries of the Organization for Economic Cooperation and Development (OECD) (Organization for Economic Cooperation and Development 1998). As a consequence, Japan's national government tended in the 1990s to favor this sector when it wanted to implement an anti-recession policy and revive domestic demand, reducing the trade surplus, which was the primary point of contention in its relationship with the United States. 
Second, after many years of large public-works expenditures, Japan has now a significant stock of public infrastructure that must be kept in repair - a major task in a country like Japan, which is constantly subjected to earthquakes and typhoons. The high level of these maintenance costs obliges Japanese local communities to allocate a large part of their expenses to the upkeep of public infrastructure. It is also clear that, in preparing their plans to construct and manage public works, local governments competed to attract the best possible projects for public infrastructure (the longest bridges, for example), with the inevitable result of overstating their public-works expenses.

Last, a most shameful reason could be added to the two presented above, which is financial contributions to political parties. The public-works companies are, in fact, the main legal financing sources for the Liberal Democratic Party (LDP) (Jimintô) which receives more than half of these subsidies and has run the national government since the end of World War II (Ribault, 1998) (see also Chapter 8).

Both the national government and private companies failed to fully appreciate the nature of the crisis following the collapse of the bubble. Viewing it as a temporary rather than a structural phenomenon, the government focused on Keynesian economic-revival policies that emphasized public works. This neglect at the outset to implement a deep structural reform of the Japanese economy resulted in the inefficacy of the revival plans.

\section{Changes in the relationships between local governments and the private sector}

During the 1980s and 1990s, in addition to projects dedicated to land-use planning, the government enacted several laws on urban development as discussed in the preceding chapters, which led to an evolution of the relationship between local governments and private companies. Each law established specific zones devoted to urban, coastline, or leisure development projects. Prefectures and municipalities had to establish basic infrastructures in order to facilitate investment by private companies in the zones created by these new laws.

Private companies, as a condition for participating in these projects, asked local governments to share the risk involved in the projects. Local governments have been involved extensively in the management of these projects - which were by and large impressive - collaborating with the private sector in the form of a public-private company. In these companies, capital is shared with local communities and the private sector participates in the project. Relationships between private companies and the local public sector became deeper. The objective was to give more power to the private sector, which was considered a more efficient manager, with the local governments in the simple role of project coordinator.

During the bubble period, companies focused on the maximization of their profits by developing only speculative projects. Local governments participated in these projects through urban planning and building public infrastructures. Acting on indications by private companies, who expected to reap large profits in these 
ventures, prefectures and municipalities developed inflated public-works projects, feeding the speculation.

As the costs of these projects were high and as local governments created them in partnership with the private sector, it was impossible to stop this operation. Only during the final days, facing major financial problems, did local governments admit that they had to bring a halt to the grand projects, which by this time had generated huge deficits.

The private companies had neither made reliable studies of the probability of the risks involved nor prepared serious cost-benefit analyses, as there was a public guarantor. For their estimates, they had merely selected the most optimistic hypothesis based on the euphoric period that Japan had been experiencing since the mid-1980s. Additionally, the multiplication of many similar competing projects had not been taken into account. Thus, most of the golf courses or amusement parks that were built had to cope with severe competition and a steep drop in attendance at the end of the 1990s.

\section{Policies for the restoration of local public finances}

To succeed in putting local public finances on a sound footing, three main means were suggested by the Ministry of General Affairs: controlling expenses by decreasing wages, reducing personnel through attrition, and, last, shrinking bonuses. Municipalities and prefectures, which were affected by the Financial Reconstruction Law of 1998, received a loan in order to adjust their debt in 1999. As a corollary, they were audited more closely by the national government, which required them to decrease their operating expenses and limit their issuance of bonds.

Although the Ministry of General Affairs recommended that expenditures on public works be restricted because of the high level of debt carried by local governments, this point of view ran counter to the national government's desire to buttress the national economy at the end of the 1990s.

Since Prime Minister Koizumi Junichirô's arrival power in 2001, a new direction aimed at limiting public-works spending has taken shape. The goal is to reduce by half the expenses in this field in the local budgets. This new policy faces resistance from the LDP, as well as from the strong construction and public-works lobby.

In April 2000, a new law designed to enforce decentralization was enacted as discussed by Ishida Yorifusa in Chapter 2. Its main features were a new distribution of functions between the state and local communities and a reform of local finances with the goal of guaranteeing local revenues. This new law was based on the ideas of the Committee for the Promotion of Decentralization (chihô bunken suishin iinkai), which holds that it is necessary to equal relationships between central and local governments. The aim was to turn Japan into a decentralized state.

In terms of powers, the law stipulated two categories of local activities: autonomous activities and activities governed by law. The distribution of activities is 


\section{Schebath}

clearly defined for cities that manage public services for the local population. The role of the prefectures is to provide support to cities and to supervise them; this role was formerly the responsibility of ministries. Clearly, with an incorporation of the proposals by the committee, the powers of local communities increased.

Parallel to this new law, the central administration created "super ministries" (Nikkei 1999). Thus the Ministry of Local Affairs (Jichishô) was merged with the Ministry of General Affairs together with the Postal Ministry and the Ministry of General Affairs and Administrative Coordination. This move has been considered, by experts, as promoting the subordination of prefectures to the national government rather than encouraging the initially hoped-for cooperation.

Compared with other developed countries, the share of revenues raised by Japanese local government taxes is very low and the rate of funding from national government grants is very high (Aoki 2001: 105). The Committee for the Promotion of Decentralization in its reports asked the state to reinforce the percentage of revenues coming from local communities in the total of the financial resources of local communities. The 2000 law on decentralization proposed several changes in local finances. Probably the most notable was the end of the system of authorization required for local communities to create new taxes ("extra-legal" taxes). According to the law, the prefectural governor must provide prior agreement before a city can establish a new tax. As will be discussed below, however, while numerous local communities seized this opportunity, new taxes did not offer the expected panacea. In addition, the 2000 law authorized prefectures and municipalities to abolish the ceiling on the resident tax, but few city governments decided to increase this tax for fear of alienating their voters.

In summary, compared with the wide range of new activities assumed by local communities, there was a clear lack of guaranteed stable and steady revenues. At the beginning of the 2000s, the national government, experiencing financial difficulties - the public debt hovered at 150 percent of GNP with the national budget financed 40 percent by bonds - attempted to heavily reduce fund transfers to municipalities and prefectures.

Furthermore, in the early 2000s, the Ministry of General Affairs was convinced of the need to reform the financial organization and structure of the local public sector in order to stabilize financial resources, especially local taxes and the global grant. One of the solutions coming from the ministry was to give a part of the revenues deriving from VAT to local communities. Once again, other ministries, and especially the Ministry of Finance, did not universally favor steps of this kind, which did not really support the idea of local financial autonomy (Okurasho 1999). It is clear that any changes of the local taxes can be implemented only when economic growth is considered sound and stable.

For the government and financial circles, the goal of decentralization has been to improve the efficiency of management and organization of local communities. The 2000 law is part of a vast movement of administrative reform that has accompanied the merger of municipalities and is not connected per se with a real policy of decentralization. This idea of a modestly supportive state existed in Japanese national policy as far back as the 1980s. In the early 2000s, the issue of the share 
of the public sector versus that of local governments in the national economy still remains to be clearly defined.

\section{Responses of local communities to financial problems}

Local communities have reacted to these financial stresses in a number of ways. One is a reduction in spending. As a result of pressure by the national government on prefectures and municipalities to lower personnel expenses, in the early $2000 \mathrm{~s}$, several prefectures implemented plans to cut their workforce. For example, Tottori prefecture decided to reduce the salaries and bonuses of 11,500 staff members by 5 percent over three years, starting in April 2002. The Tokyo Metropolitan Government (TMG) reduced the salaries of its employees by 4 percent over two years, beginning in April 2000. Nineteen other prefectures followed the same model but, as demonstrated by the case of Kanagawa, this did not solve the financial issues.

In 1999, the national government urged the Kanagawa prefectural government to reduce its spending on personnel, which represented 49 percent of its budget. But out of the total amount accounting for employee expenses, the most important part is not really controlled by the prefectural government. In fact, while the local government is able to determine the salaries of a prefecture's civil servants, this segment represents only 6.6 percent of the total amount, which, of course, limits the capacity to dramatically reduce operating expenses by decreasing personnel expenses. It is clear that the policy proposed by the national government is not a solution that seriously addresses the predicament of the local public sector.

Kanagawa prefecture was one of the local governments that welcomed the financial reconstruction plan of 1998. A contingency of receiving funds through this loan was that the prefecture had to reduce its personnel expenditure. Prefectural authorities set as a goal for the fiscal year 1998-9 a decrease in operating expenses to 60 billion yen. These would be achieved through a decrease of 10 percent in the bonuses for managers, a reduction in internal management costs, and the reduction of all public-service activities. Kanagawa prefecture set three main "10-percent" objectives: limiting the issuance of loans to 10 percent of the amount of revenues, reducing 10 percent of the employees working in the governor's cabinet, and reducing the number of departments in the prefecture's main office by 10 percent over five years. Moreover, in 1999, the independent expenditures (not under the control of the national government) decreased by 30 percent. Finally, by March 2000 , work and retirement bonuses were reduced to one-quarter, the personnel for general activities was reduced by 8 percent, and management personnel was reduced by 15 and 30 percent, depending on the department.

Osaka prefecture also faces a very difficult situation in terms of its local tax revenues. It began fiscal year 2002 with less than 1.25 billion yen in tax revenues, which failed to achieve the target outlined in its administrative and financial reform plan produced under pressure from the central government. Osaka prefecture claimed that by implementing the reform plan, including large-scale restructuring of its administrative activities, it would be able to avoid incurring 


\section{Schebath}

deficits so high that it would force the central government to take charge of its finances. Nevertheless the revenue shortfall meant that it was much more difficult to implement the plan. With debts totaling about 44 billion yen, Osaka feared a government takeover of its finances at the end of the fiscal year 2006. It decided to draw up a long-term package of reforms, including laying off 3,000 employees, curtailing spending on construction projects by 10 percent, and conducting annual reviews of fiscal policy. To make matters worse, the regional economy has suffered additional setbacks, with scores of firms going out of business. In the next few years, corporate tax revenues are expected to be even lower than in 2001 .

Going beyond salary reductions, local communities decided to reduce general spending and especially that related to autonomous activities. The total local budget decreased 1.8 percent between 2001 and 2002, and autonomous spending by 10 percent, while a reduction in staff of 12,000 local civil servants occurred. Spending reductions took place mainly in the area of public works. This is a substantial reform that affects all projects (airports, Shinkansen (bullet train) lines, dams, and so on). A majority of people (citizens and experts) agreed that trying to revive the economy by increasing spending for public works, as happened during the 1990s, had no effect except to allow Japan to reach record levels of public debt. The promotion of unnecessary public works stands accused of bearing primary responsibility for these debts. There is a strong movement in favor of transferring public-works spending from rural areas to large cities where most inhabitants are located, running the risk of an increased population drain from those cities.

The second way local communities react to financial stress is by creating new local taxes. With the 2000 law on decentralization that allowed prefectures and municipalities to establish new taxes, several communities have followed a policy of guaranteeing financial resources and focused on new taxes affecting large industries. Local communities that avoid soliciting private companies are less numerous; indeed, those that create such new taxes do so with the approval of residents for specific purposes, such as environmental protection or health care (Nakanishi Harufumi 2000). The trend toward levying taxes affecting private companies is seen as addressing the inequities in the existing system that enables two-thirds of all corporations to escape paying prefectural taxes.

In any case, companies ask that corporate tax increases be followed by efforts from local communities to reduce their expenses. Some of these new taxes include Yokohama's tax on betting (horse racing, pachinko parlors, and so on); Mie prefecture's tax on industrial waste; the Tokyo district Minato-ku's tax on cigarette vending machines; and Yamanashi prefecture's road tax. Certain taxes have a dual goal: hence Suginami-ku obliges supermarket customers to pay 5 yen for every plastic shopping bag they use. In addition to an increase in revenues, this tax also aims to reduce the volume of environmental waste.

But no doubt the most symptomatic example of the creation of new taxes, and the negative reactions they arouse, has been the bank tax that Tokyo's governor, Ishihara Shintaro, established in April 2000. This tax applies to financial institutions with a capital accumulation in excess of 5 billion yen and that are headquartered in Tokyo. Those institutions with deficits (not uncommon because 
the repayment of bad loans by Japanese companies has been affected by the economic crisis) are exempt from the corporate tax. It is clear that this new tax had both a financial objective (to increase revenues) and a political one (banks are considered responsible for the economic crisis of the 1990s). Twenty-one banks reacted by bringing the matter to court in October 2000, claiming that the tax was inequitable. The Japanese government supported the legal case, as the tax was considered risky for the country's already troubled financial system. On March 26, 2002, judges ruled that the new tax should be abolished because it went against local taxation laws. The decision explained that for the creation of new taxes the difference between the amount of tax levied and the profit earned by the private companies must be significant; and for the judges in the bank case it was too small to be justifiable.

This ruling shows that the principle of fiscal autonomy written into the decentralization law of 2000 is more a matter of theory than fact. In April 2002, the Ministry of General Affairs, which had partial responsibility for the management of decentralization along with local communities, cautioned cities against introducing taxes other than those provided for by national law. In summary, local communities cannot expect new taxes to be the solution to their financial problems. From a macroeconomic perspective, increasing taxes will have a purely negative impact on personal consumption and investment by corporations during times when the growth rate of the country is expected to be weak over a period of several years.

Recent actions support the position that, confronted with the financial crisis of local communities, the national government must help the local fiscal system to evolve. Beginning in April 2004, prefectures were permitted to increase taxes on corporations by 20 percent (up from 10 percent) over the rate fixed by the national government. The Committee for the Control of Public Finance (Jimintô zeisei chôsakai) of the LDP has argued that this is an opportunity to authorize prefectures to establish taxes for companies with deficits, which now escape corporate taxation.

\section{Recommendations by scholars}

A number of economics scholars have weighed in on the 2000 decentralization law. The Committee for the Promotion of Decentralization has recommended that financial relationships between national and local governments be founded on the principle that expenditures must be linked to the realization of public services by local communities. The lack of transparency in the redistribution of powers between national and local levels must be addressed. Clarification of the roles of each should enable local governments to secure funding commensurate with expenses in the event that they undertake an activity (for education, police, or infrastructure) normally assumed at the national level. After this first step, a real guarantee of local fiscal resources must be established through the creation of a taxation system that provides stable revenues to prefectures and municipalities (Chihô bunken suishin iinkai 1997). 
Economists for the most part believe that the guarantee of local resources has not been considered by the 2000 law. For a true strategy of decentralization to be implemented, it must first protect independent activities and provide real autonomous power to local communities (Kanazawa 2000). But under the law as it stands, there are still 275 functions that remain delegated. Judicial rulings that inhibit the levying of new taxes, as seen above, demonstrate clearly that local financial autonomy continues to be an illusion.

Experts recommend stabilizing local revenues and transfers of funds from the state. As was seen during the 1980s and 1990s, and with the 2000 law on decentralization, the national government transferred to local governments a part of its area of responsibility, particularly in the domain of social welfare, but this was not accompanied by an increase in local financial resources, leading to a too-heavy local expense burden in recent years. This problem must be resolved by enlarging the local tax base. To do so, it will be necessary to completely reform the structure whereby national and local tax revenues - which often have the same base - are distributed. Presently, as noted earlier in this essay, revenues are distributed twothirds at the national level and one-third at the local level. To guarantee stable financial resources for prefectures and municipalities, the consumption and residential tax base must be enlarged, with the aim of increasing the share received by local governments (Jinno 1998). If the resident tax rate were to be increased by 10 percent, for example, local communities would raise 11 trillion additional yen and would receive nearly 61 percent of the income tax. Meanwhile, the national resident tax must be reduced in the same proportion, as the objective is not to increase the level of taxation, but to transfer resources from the national budget to local budgets by strengthening the financial autonomy of local governments. The goal, in fact, is to increase local resources from local taxes and reduce funds transferred from the national budget, especially Treasury disbursements and the global grant, thereby reinforcing local autonomy.

The creation of extra-legal taxes is intended to give independent revenues to local communities. Four main reasons favor reforming the tax system. The first is that fluctuations in the economy generate instability in terms of financial resources. The creation of new taxes based on more appropriate standards would provide a more stable income to cities and prefectures. A second reason is that prefectures provide public services that are used by some corporations that do not pay a local tax. A new tax could establish greater parity between the taxes paid by corporations and the benefits they receive. This could lead to a more equal distribution of costs, and will avoid limiting the development of new areas that benefit the economy in general. A final reason is that the delay in reviving the economy increases the unequal development among local communities.

Economists do not conceal the fact that these taxes (outside the standards) are not without problems. Among the concerns are the disparity among the number and amount of taxes paid, which vary according to the type of corporation or activity; the dissatisfaction of corporations that have not previously paid such taxes; and the impediment to start-ups that are not financially sound enough to pay taxes quickly. According to Jinno Naohiko of Tokyo University, these new taxes need 
to have a clear objective in order to be accepted by the population. After the initial boom, local communities understood that new taxes should be approved by the Ministry of General Affairs and by local residents. While residents are typically reluctant to permit prefectures and municipalities to raise taxes during an economic crisis, as seen previously, the creation of new taxes is ultimately accepted by local communities. For example, in the late 1990s, Kanagawa prefecture proposed an environmental tax as well as a tax for the treatment of wastewater.

Experts in local public finance believe that it is actually the lack of financial autonomy that has led to local financial problems. Under the influence of the national government, during the 1990s municipalities and prefectures have conducted activities that generated a huge amount of debt, and they are now obliged to reduce their personnel and curtail some public services under pressure by various ministries. It is thus necessary to strengthen the independent decision-making powers of the local governments to truly resolve this crisis (Kanazawa 1998). Financial experts also believe that, with fiscal autonomy, local governments could have more responsibility and meet the demands of their residents (Nakanishi Hiroyuki 2000). Each prefecture and municipality would be able to respect more closely the needs of its population and develop its own particular public services. In so doing, local governments would no longer be able to shift responsibility for their actions onto the national government, but would have to assume the management of their own affairs, resulting in their avoiding collaboration on projects deemed too high a financial risk.

The question of financial relations between the state and local communities is the one that currently generates the most discussion. The existing system of funding should be reformed by basing it on a clear distribution of activities and a respect for local autonomy. The volume of installments by the Treasury has in fact decreased with the new distribution of areas of competencies according to the 2000 decentralization law. The goal is to eliminate funding that is tied to subordinate relationships between national ministries and local communities. But this reduction in subvention should be accompanied by an equivalent rise in independent financial resources, which is not the case under the new 2000 law.

The main function of the second main fund transfer, the global grant, is to adjust the gap in revenue between the state and prefectures and municipalities mentioned above. The mode of calculation and the split of transfer of funds among local communities are extremely complex and subject to criticism. This system of adjustment aims to provide all local communities with a "national minimum" (a minimum administrative standard that is applied throughout the entire country), funded by the national government (Aoki 2001). Because of the national government's precarious financial situation, however, it chose to fund this transfer not through the global grant but by loans, part of which must be repaid by local communities. This in turn contributes to an increase in local debt, as seen in the first section of this essay. In the 1990s the Ministry of Finance attempted by all possible means to reduce the amount of the global grant. According to the mass media and public opinion local cities have wasted public monies with ill-conceived public works. Faced with budget deficits (in the early 2000s, the 
national budget was financed 40 percent by public bonds and the budget deficit reached 7.4 percent of GNP in 2003), the Ministry of Finance started a publicity campaign linking the increase in the deficit to this irresponsible behavior, which necessitated a reduction in funding from the national government. One of the proposed solutions has been to encourage the merging of villages and small cities, which would permit a more efficient management of rural areas, as well as reduce the number of local communities receiving a transfer of national funds. However, the disbursement of the global grant, which is controlled by the national government, appears to be trapped in a power play between different ministries. Transparency in the process of deciding who gets what part of the funding needs to be improved so that all local communities are able to understand the process and approve of it. In short, Japanese local public finances, and more particularly their coordination, are poised for change.

\section{Conclusion}

The dire financial situation of the Japanese local public sector necessitates important structural changes. These changes imply that the relationship of subordination between central government and local levels disappears in favor of intergovernmental relationships based on equity between the partners. Policies that reinforce an overly strong dependency of local communities on the national government carry serious risks of precipitating a financial crisis. The implementation of structural reforms will allow for the creation of equal partnerships between central and local levels.

While it is clear that it is a principal means of financial restoration at a national as well as local level, the most recent decentralization law, of 2000, seems not to follow this direction, and financial autonomy of the local public sector is still lacking. This is a missed opportunity to establish a new system of relations between the state and local communities. The private commercial sector and the government are attempting to move Japan toward only modest state support and encourage local communities to follow this example of offering a minimum of public services. Municipalities and prefectures must manage this governmental pressure in parallel with a broadening of their powers but must also address an aging population, which increases the need for social spending. The most successful solution to this crisis might be to increase popular involvement in local financial management. A local referendum should be used to decide whether or not new services or new taxes should be accepted. Residents should have the right to decide for themselves the conditions under which public services should operate, as they are the main beneficiaries of these services. Such a move would enhance the legitimacy of actions taken by local communities and allow a better adaptation of local public services to the evolution of the future needs of the society.

\section{Note}

1 In 2004, the Japanese local public sector included 47 prefectures and 2,927 municipalities, which were broken down into 712 cities (shi) 1,734 towns (chô), and 
481 villages (son) (see Schebath 2000: 117-28 for a discussion of the structure of the Japanese local public sector).

\section{References}

Aoki, Muneaki (2001) "La dotation fiscale globale: Un point clé du système administratif au Japon," Revue Française de Finances Publiques 75: 103-16.

Aoyama Akihisa (1998) "Kuniizon wa bunken ni shôgai" (Dependence on the state is an obstacle to decentralization), Yomiuri shimbun November 8: 13.

Chihô bunken suishin iinkai (Committee for the Promotion of Decentralization) (1997) Daiichi kankoku: bunken suishinkata shakai no sôzô (First recommendations: the creation of a decentralized society), Tokyo: Gyôsei.

Jichishô (Ministry of Local Affairs) (1999) Chihô zaisei no jôkyô (The status of local public finance), Tokyo: Publications of the Ministry of Finance, March.

Jinno Naohiko (1998) "Zeigen ijô fukume bunken suishin" (Change the tax base including the promotion of decentralization), Nikkei October 15: 31.

Kanazawa Fumio (1997) "Chihô ni jiko ketteiken to zaisei seido" (The local public finance system and autonomous decision-making), Toshi mondai 88(5), May: 27-42.

_(1998) "Jichitai zaisei he no keishô, Jichitai no jiritsu to sentaku suru yûki" (Alarm bell of local public finance: to have the courage to choose the autonomy of local communities), Chihô jichi shokuin kenshû 10: 18-21.

_(1999) "Jichitai zaiseikiken no kôzô yôin" (Structural reasons for the dangerous state of local communities), in Dainankai zenkoku taikai hôkoku yôshi, paper presented at the annual conference of the Japanese local public finance society, Takamatsu, Japan, May 29-30: 9-12.

- (2000) "Chihô bunken ikkatsuhô ni miru: 21 seiki no chô zaisei" (A look at the global law on decentralization: local public finances in the twenty-first century), Chiho jichi shokuin kenshô (Training of local public servants) 1(447), January 15: 31-4.

Kaneko Masaru (1998) "Chihôsai hikiukekikan no shinsetsu wo" (Establish a new organization to assume local public debt), Nikkei October 16: 31.

Nakanishi Harufumi (2000) "Jimae no zei, jichitai de zokuzoku" (Fiscal autonomy, local communities join the movement one after another), Nikkei September 14: 32.

Nakanishi Hiroyuki (2000) "Chihô seidokaiku: bunkenka to gyôsei kaikaku no nyômen kara shinko" (Reform of local public sector fiscal policy: progression from the two poles of administrative and decentralization reforms), Keizai 9(60), September: 113-15.

Nikkei (1999) "21 isseki no gyôsei he aojashin" (The plan for an administration of the twenty-first century), July 9: 7.

Nomura Yoshifumi (1999) "Zaisei kenzenka he no torikumi" (Matching the return of soundness for public finance), Chihô zaisei 5, May: 160-76.

Okurashô (Ministry of Finance) (1999) Zaisei no genjô to kongo no arikata (Actual public finance and recommendations for the future), Tokyo: Publications of the Ministry of Finance, July.

Organization for Economic Cooperation and Development (OECD) (1998) Japon, études économiques de l'OCDE: accrôtre le dynamisme des entreprises, les difficultés du secteur bancaire, Paris: Publications of the OECD.

Pons, Philippe (1998) "D'importantes municipalités sont menacées de faillite," Le Monde, November 5: 14.

Ribault, Thierry (1998) "La ruine du keynesianisme du beton au Japon," Le Monde-Enjeux, May 5: 5. 


\section{Schebath}

Satô Norio (1998) "Jichitai tôsan no kiken; Ôsaka-fu, saiken tsuna watari" (Osaka prefecture danger: a local community bankrupted, a reconstruction by walking the tightrope), Nikkei, May 25: 30-1.

Schebath, Alain (1999) "Les finances publiques locales au Japon," Revue Française de Finances Publiques 65, March: 151-68.

-(2000) "Les collectivités locales japonaises, organisation et relations intergouvernmentales," Ebisu 3, Spring-Summer: 117-40.

Shimizu Hidenori, Tani Takanori, and Toyofuku Hiroshi (1998) "Kiken no jichitai" (The danger of local communities), Nikkei, November 11-15: 14.

Sômushô (Ministry of General Affairs) (2001, 2003, and 2004) Chihô zaisei no jokyô, chihô zaisei hakusho (The state of local public finance: white paper on local public finance), Tokyo: Publications of the Ministry of Finance, March.

Wada Yatsuka, Noro Akiro, Hoshino Izumi, and Aoki Muneaki (1999) Gendai no chihô zaisei (Actual status of local public finance), 2nd edn, Tokyo: Yuuhikaku. 


\title{
5 Centralization, urban planning governance, and citizen participation in Japan
}

\author{
André Sorensen
}

Many observers agree that Japanese society at the beginning of the twenty-first century is at a major turning point. During the 1990s, economic stagnation combined with apparent political gridlock to produce what is widely described as the collapse of the "1955 system" of developmental state collusion between the long-ruling Liberal Democratic Party (LDP), the national bureaucracy, and big business, which built the Japanese economic miracle of the 1950s and 1960s and transformed Japan into a high-technology and manufacturing-based economic superpower in the 1970s and 1980s (Garon and Mochizuki 1993; Iida 1994; Pempel 1998) (see also Chapters 1 and 8 by Hein and Pelletier in this volume). Unfortunately, during the 1990s, solutions were found neither for the political impasse this created nor for the economic doldrums stemming from the collapse of the late 1980s asset-inflation bubble, giving rise to the common description of the 1990s as a "lost decade" for Japan with regard to failed efforts at economic reconstruction and political reform.

For urban governance, city planning, and community development, however, the 1990s are just as widely seen as a time of dramatic transformation in Japan, with a veritable paradigm shift in planning practice and the development of local democracy (Watanabe 2000). A key aspect of this transformation is the emergence of new patterns of citizen engagement in local environmental governance, of which machizukuri movements are a prominent and widespread example (see Chapter 6 by Watanabe Shun-ichi in this volume). While a wide variety of local community-development related activities are now referred to as machizukuri, the term is used here to refer to participatory community-based efforts to improve local environments. The decentralization of central government functions to local governments, including responsibility for city planning, is seen as an important part of that process (Chihô bunken suishin iinkai 1997; Kobayashi 1999).

Decentralization and the shift to greater citizen engagement in local environmental governance in Japan parallel similar changes in many other countries around the world. The worldwide trend toward the decentralization of powers from national to provincial and local governments, the international wave of democratization since the 1970s, and increased aspirations of civil society organizations for environmental policy roles have all led to increased interest in local governance (Stren 2002). Some have argued that these shifts are also closely associated with 
globalization, as increased mobility of investment and greater international trade flows weaken the policy autonomy of individual nation-states at the same time as increased competition for mobile investment heightens the competition between cities (Castells 1997; Low et al. 2000: 281-307). With the global spread of the idea of urban sustainability as a dominant conceptual framework for urban policy, one of the major areas of concern is urban planning and local environmental governance. This is reflected in the Local Agenda 21 program, initiated at the 1992 Rio Earth Summit, which envisions local governments, communities, and citizens as the key actors in efforts to achieve greater environmental sustainability (Sitarz 1993; United Nations Department of Public Information 1993; Low et al. 2000). City planning and local environmental management are thus a key focus of changing governance structures, lying as they do at the intersection of national economic interests with the hopes and aspirations of local communities for healthy, safe, and congenial living environments. As the famous Spanish theorists Jordi Borja and Manuell Castells (1997) put it, the major question facing us at the beginning of the twenty-first century is: How do cities, citizens, and local governments become the primary actors in shaping their destiny in the new world economy?

It is clear that the division of responsibilities and powers between local and national and between state and citizens is undergoing a period of change, renegotiation, and reconceptualization. Such changes are occurring in countries around the world, not least in Japan. These changes present opportunities for understanding relationships old and new, as old certainties are questioned and new formulations required. The intent of the following discussion is to take advantage of this moment, when many of the old arrangements are being questioned, to examine Japanese planning culture - defined here as the set of institutional arrangements and shared understandings about the appropriate roles and meanings of state, market, and society in urban management. Japan's particular trajectory of urban governance, its highly centralized system of urban planning, and its distinctive relationships between state, market, and society provide a valuable opportunity to explore some of the implications of the nation's twentieth-century history of centralized urban governance. The main issues to consider are the important long-term consequences of the high degree of centralization in Japanese urban governance; the role and contribution of civil society actors in relation to urban governance in the context of that centralization; the ways in which governance structures have worked to shape civil society; and, finally, the relationships between urban planning governance, civil society, and urban change in Japan.

The first section outlines the main characteristics of Japan's centralized governance system through an analysis of the local government and urban planning systems. Japan succeeded in creating one of the most highly centralized urban planning governance systems among the developed countries (see also Chapters 1 and 2 by Hein and Pelletier, and Ishida respectively). As an extreme form of top-down, centralized control over urban management, the Japanese case provides useful insights into the advantages and disadvantages of the centralization of spatial management powers. The top-down view is only one side of the story, however, and without also examining the bottom-up perspective of the efforts 
of communities to work together to enhance local environments, the picture of Japanese urban management would be incomplete. The second section examines the roles of communities in bottom-up management of urban space. In many respects local communities have shown continuing strength in Japan, while in other ways their autonomy and ability to effectively protect their local environment have been limited consistently by the policies of the central government. The resulting contradictory character of Japanese urban governance, with a weak role for civil society, but strong neighborhoods and social capital resources, is a central feature of Japanese urban life that this discussion tries to elucidate. The third section explores some of the consequences of Japan's distinctive urban planning culture in order to gain perspective on recent moves to decentralize planning authority.

\section{Centralized governance and planning}

To understand the significance of recent attempts to decentralize Japanese urban governance, it is important first to understand the extraordinarily centralized system established when the modern Japanese state was created a century ago, and the enduring impacts that has had on governance structures. The origins of the centralized government system lie in the Meiji period (1868-1912); during the previous Tokugawa period (1600-1867), despite the fact that the shogun and his vassals controlled about one-third of the country directly, and the remaining feudal lords indirectly through a combination of alliances and coercion, the roughly 300 feudal domains were relatively independent, with their own taxes, laws, and military forces.

In the early to mid-1800s, the growing military threat of the Western powers led increasing numbers of the samurai ruling class to conclude that the old decentralized system of feudal governance under the shogun was insufficient to protect Japan from colonization. This combined with the resentment of Tokugawa power by the large domains of southwestern Japan to provide fuel for a successful rebellion, which overthrew the old system and created a new national government in Tokyo under Emperor Meiji. Established in the interest of national strength, the reforms of the first half of the Meiji period were virtually all geared toward the consolidation of power in the national government and weakening the independence of local administrations. The need for a stronger national state, modern military technology, and national unity was clear enough that thoroughgoing reforms, undoing much of the former order and consolidating central power, were implemented rather swiftly and with relatively little opposition (Jansen and Rozman 1986).

The first decades of the Meiji period were thus a time of concentration of power in Tokyo, which saw the creation of new national institutions of governance based on central ministries, a national tax system, and a modern national army and navy composed of conscripts rather than the old samurai military class (Gluck 1987; Westney 1987; Hunter 1989). While a two-tier system of local government was established throughout the country, consisting of an upper level 
of 47 prefectures (ken), and a lower level of municipalities (shi chô son), these had little legal, financial, or policy-making independence (see Chapters 1 and 2). Prefectural governors were appointed by the Home Ministry (Naimushô), usually from high-ranking ministry bureaucrats. Despite the fact that elected prefectural and municipal assemblies were established, the appointed governors retained the power to pass laws and set budgets, overriding the wishes of the local assembly if necessary. The local governance system created during the Meiji period was thus primarily a means of extending central government power over local areas, rather than an attempt to build democratic local governments.

Two aspects of the governance system established in the Meiji period, which continued in force until the establishment of a new constitution under the postWorld War II occupation, are particularly relevant to urban planning. The first is the extraordinary concentration of power in the Home Ministry, which was responsible for local government, the police, city planning, public health, and civil engineering, among other policy areas. Kurt Steiner suggests that during the Meiji period the Home Ministry "became an efficient bureaucracy, fulfilling their task with a jealous enthusiasm that prohibited the delegation of power to decide even the smallest details. It has justly been said that the establishment of the Home Ministry helps to account for the peculiarly centralized nature of Japanese government and that local government in Japan cannot be understood without reference to this bureaucracy" (Steiner 1965: 26). While, as the prominent Japanese political scientist Muramatsu Michio points out, there was considerable variation in actual practice, with some prefectural governors able to create a greater or lesser degree of maneuvering room for alternative policy approaches, the overall picture is one of effective central constraints on local autonomy (Muramatsu 1997; see also Reed 1986).

The second significant feature of the Meiji system concerned the legal arrangements that permitted continued central influence over local governments even after governors had become directly elected officers under the postwar constitution. For example, the central government retained the exclusive authority to pass laws and regulations and to set tax rates. While local governments could enforce regulations set by the central government, they were given no authority to pass and enforce their own rules on even trivial matters (Steiner 1965: 50). Transfers of personnel from central ministries to top positions in prefectural and local governments are still routine and widespread today, allowing effective central supervision and quick dissemination of new policy approaches (Samuels 1983). Probably even more important in the long run was the system of "agency-delegated functions" (kikan inin jimu), which allowed central ministries to delegate specific tasks, such as public health measures, policing, and city planning, to prefectural and municipal governments, while retaining exclusive authority to make policy decisions. When such functions were delegated to local governments, the governor, in the case of prefectures, and the mayor, in the case of municipalities, became the agent of the central ministry, and had no choice but to carry out ministry orders even if doing so directly countered the wishes of their own electorate. This system ensured central ministry constraints over local government planning 
policy, and remained a powerful determinant of planning outcomes until city planning responsibility became officially a local government function (no longer a delegated function) in May 2000.

The highly centralized system of governance had an important impact on city planning. The first attempt by the national government to create a modern city planning system was the 1919 City Planning Law (toshi keikaku hô) and its accompanying Urban Building Law (shigaichi kenchiku butsu hô) discussed by Ishida Yorifusa in Chapter 2. The only prior central government city planning legislation, the Tokyo Urban Area Improvement Ordinance (Tôkyô shiku kaisei jôrei) of 1889, had been concerned primarily with the improvement of the existing built-up area of Tokyo, and had been applied mainly to specific development or redevelopment projects. The 1919 legislation introduced land-use zoning, building controls, and a system for planning entire urban areas larger than individual municipalities. The fragmented nature of these municipalities was a strong argument in favor of planning at the national level to coordinate the creation of major infrastructure. The 1919 law remained the basic planning legislation for a half century, until it was replaced by the New City Planning Law of 1968 (shin toshi keikaku hô). The 1919 law thus provided the planning framework for urban growth in the critical post-World War II period of rapid economic growth.

Ishida has argued that a further serious problem of the 1919 law was its strong centralization of planning authority (Ishida 1987: 114-15, and Chapter 2 in this volume). Whereas before 1919 there had been no national city planning legislation, and local governments had been free to carry out whatever local planning they could manage, with the passage of the new laws in 1919 national legislation took precedence. As with the Tokyo Urban Area Improvement Ordinance, all plans had to be approved by the Home Ministry, and annual city planning budgets were required to be authorized by the ministry in order to be eligible for central subsidies. The 1919 system in this way significantly extended the powers of central government bureaucrats over local city planning efforts. Furthermore, the national legislation imposed a single set of land-use zones and building regulations on the whole country, even though cities had quite different urban patterns and urban problems. Local governments were not permitted to modify the zoning system to make it more relevant to diverse local conditions (Sorensen 2002: 118). The Japanese urban planning system before the major reforms of 1968 was characterized by its high degree of centralization of power in national ministries, a weak financial base, and an orientation toward project planning and implementation rather than regulation of private development activity. The prewar planning system was well suited to the pursuit of national industrial and military growth, allowing effective central planning and development of the national territory (Johnson 1986). Unfortunately, central government policies also led during World War II to national destruction as well as to an enormous loss of life, both of Japanese citizens and those of the countries Japan invaded.

There is no doubt that Japan was changed greatly by its defeat in 1945 and by the reforms carried out by the American-led occupation authorities who were determined to eliminate those aspects of the Japanese political system that had 
allowed the development of totalitarianism and wartime aggression. Abolition of the military, the passage of a new constitution that declared the people sovereign and demoted the emperor to symbolic status without real power, the introduction of universal adult suffrage, and a sweeping land reform that redistributed farmland from landlords to their tenants were all major changes. Many of the reforms were adopted readily and willingly by the Japanese, who had seen their country impoverished, defeated, and stripped of its independence as a result of the government's wartime policies (Dower 1999). As the American historian Gary Allinson has argued, however, there were significant continuities in Japanese governance structures before and after the war. Those occupation reforms that had strong Japanese support both inside and outside government had lasting impact, while other reforms that lacked such support were either difficult to implement or reversed when the occupation ended (Allinson 1997).

In order to create a stronger, more independent level of local governments, the occupation insisted on directly elected prefectural and municipal chief executives and legislatures and abolished the formerly powerful Home Ministry. As shown by Ishida (see Chapter 2), the establishment of more independent local governments and a stronger local role in city planning was not a high priority for the Japanese government. This is perhaps understandable given the scale of reconstruction necessary, and the extent of economic problems facing the country, but in practice, despite opposition reforms, local governments and the system of city planning remained tightly constrained by central government officials who worked hard to maintain their old dominance over local affairs. As Allinson explains:

Allied reformers underestimated the determination of former officials from the old Home Ministry who staffed the new (Local Autonomy) agency - men who never abandoned their desire to preserve every ounce of control over local affairs. Central officials sought control through three avenues: finance, duties, and personnel. They tried to keep local governments dependent by forcing them to rely on central government grants, rather than local resources, for their operating revenues. They subordinated local governments by requiring them to carry out a wide range of duties mandated by the national government, and they tried to subvert local autonomy by appointing incumbent and retired central government officials to the best administrative positions in cities and prefectures.

(Allinson 1997: 72)

Local government taxation powers were closely controlled by the central Ministry of Finance, and the central government continued to mandate a wide range of programs with what many local governments saw as inadequate financial compensation (see Chapter 4 by Alain Schebath in this volume). This issue is commonly referred to as the problem of "excess burdens" placed on local governments without sufficient compensation (Shindô 1984: 119). Financial constraints sharply limited local policy options. As local governments could only operate within the limits of nationally set legal frameworks, it was extremely difficult for 
local governments to set their own agendas, particularly in the area of creating better planning regulations. These constraints became especially apparent during the 1970s when numerous progressive-controlled local administrations found that planning laws meant that they were unable to fulfill many of the election promises that had put them in office (Sorensen 2002: 230-43). Furthermore, many areas of activity, including policing, education, social welfare services, and city planning, were in fact merely delegated to local governments by the central government, which retained all policy-making authority. The "agency-delegated functions" system continued in effect, with responsibility for carrying out the delegated function consigned to a governor, in the case of a prefecture, or a mayor, in the case of a city. As before, the governor or mayor then automatically became responsible to the central ministry, not to his own electorate, in carrying out the delegated function.

After the war the main priority of the central government was industrial development. Because there was such a clear necessity to recover from the destruction wrought by the conflict, the alliance of central government bureaucrats, the ruling LDP, and big business was given a free rein to pursue its development strategy. MIT political scientist Richard Samuels has called the period from the end of the war to the middle of the 1960s a "conservative's paradise" in which there was an "unassailable consensus" on economic reconstruction and rapid growth (Samuels 1983: 168). During this period the Japanese government spent little on social overhead capital, instead devoting all available resources to facilitating rapid industrial growth. The emphasis on industrial growth meant that little effort was made to provide planning, infrastructure, housing, or even regulation of privately developed residential areas. Instead, the state built infrastructure essential for industrial development, such as an industrial water supply, ports and railways, highways, electrical generating capacity, and large-scale low-cost public housing projects (Morimura 1994). Most of the housing supply was left to market forces, constrained only by the weak zoning system and the building standards act first passed in 1919. For example, prior to major revisions made to the City Planning Law in 1968, landowners could subdivide lots and build as-of-right if they were in conformity with the land's zoning and the building code, even if there were no sewers, local roads, schools, or parks. Since buildings could be constructed almost anywhere within commuting range of urban areas, there was a strong tendency toward scattered development wherever land was available, and the creation of unplanned urban districts which were severely deficient in basic infrastructure. Most urban areas developed as dense mixtures of industrial, commercial, and housing uses. This pattern of urban growth, combined with very weak pollution control laws, greatly contributed to the environmental crisis of the 1960s, as toxic pollution was concentrated near residential areas (see discussion below). It is important to note that increasing protests against environmental destruction had a great impact on urban planning policy, including the passage of a new City Planning Law in 1968 (Calder 1988; Ishida 1987).

The 1968 law transferred the responsibility for preparing and enforcing urban land-use plans to local governments. The new system raised the hopes of local 
governments and planners that they would now be able to catch up with infrastructure shortfalls, control the location and standards of new development, and generally provide a better quality urban environment. Also, in the early 1970s those reform-minded local governments that had placed the improvement of the urban environment and respect for the needs of citizens at the top of their political agenda were still growing in strength and electoral success. Many progressive candidates won municipal elections on promises to improve local environments and provide the investment in social overhead capital that had been so lacking (Samuels 1983: 190; Krauss and Simcock 1980: 196).

There is no doubt that the 1968 City Planning Law represented a major change in terms of Japanese planning, and that local governments gained many more tools for local environmental management, and a much greater range of responsibilities. In retrospect, however, the continuing domination of planning policy by central government ministries made it extremely difficult for the progressives to carry out their promises. Central control - through finances, the agency-delegated-functions system, and national planning law - continued. Local governments had no legal authority to create enforceable local bylaws that went beyond the national planning law. They still had no authority to regulate minimum plot sizes, restrict the subdivision of land into smaller pieces, or create locally specific zoning ordinances or development standards. When local ordinances did impose more stringent requirements on land developers, compliance could only be negotiated on a voluntary basis (Sorensen 2002: 310-25). While the 1968 law did create the nation's first system of development permits (kaihatsu kyoka), which imposed minimum infrastructure requirements for large-scale land development, projects smaller than 1,000 square meters were exempt, with the result that more and more development was carried out in small bits to avoid the regulations (Mori 1998; Hebbert 1994). The tight control over planning regulations by the central government meant that local options were extremely limited, and urban sprawl continued to worsen (Hanayama 1986).

In response, many local governments created non-statutory "development manuals" (kaihatsu shidô yôkô) that provided for higher levels of infrastructure associated with land development than those mandated by law. These had no legal standing, but local governments used their control over the water supply and other municipal services to gain some leverage in persuading developers to provide greater infrastructure investments than required by the national law. The effectiveness of these development manuals in preventing unserviced sprawl is unclear, but the vigorous efforts of the pro-development government headed by Nakasone Yasuhiro in the mid-1980s to abolish their use suggests that they were effective in some measure in increasing the power of local governments to regulate landdevelopment activity (Hebbert and Nakai 1988). It is also noteworthy that the priority given by the Nakasone government to abolishing the development manuals is a powerful indication of the importance of land development in the Japanese political economy. In his exhaustive examination of prefectural policy-making, Steven Reed finds no such attempts to revoke the many prefectural ordinances that imposed more stringent pollution control standards than those provided for 
by national law (Reed 1986: 85). This episode suggests both that local governments were actively attempting to expand their range of planning tools and that the central government was equally determined to maintain its restrictions on local planning autonomy.

The evolution of urban planning policy since the wave of progressive local governments in the late 1960 s that emerged in response to environmental concerns can be told as a recurrent struggle between central and local government, with localities constantly pressing for more authority and central government consistently resisting significant decentralization of power (see Sorensen 2003). Whereas the increasing strength of opposition politicians in municipal and prefectural politics combined with the growing power of anti-pollution movements to push central government toward the decentralization of planning power in 1968, and toward the passage of improved environmental regulations in the early 1970s, by the 1980s the LDP had regained a strong majority in the central government and worked hard to weaken local powers of development control. The catastrophic inflation in land prices of the 1980s, and the subsequent collapse of the investment bubble in the early 1990s, signaled the end of attempts to deregulate land development and weaken local planning restrictions on it (Otake 1993). In 1989 a new Basic Land Law was passed and in 1992 a major revision of the City Planning Law granted greater municipal planning powers, and established a mandatory system of public consultation with local residents in preparing municipal master plans (Sorensen 2002: 300). During the first years of the twenty-first century the tide again seems to have turned against these moves toward decentralization of planning authority to municipal governments, with significant attempts by Koizumi Junichirô's government to deregulate property development in order to encourage a land-development-led economic recovery (see Sorensen 2003).

Perhaps the most persuasive evidence that the old patterns of governance continued in force is provided by the enormous increase in public-works spending during the 1990s. Justified as a measure designed to boost economic growth during a prolonged recession and expand domestic demand in response to foreign pressure over high trade surpluses, especially from the United States, economic stimulus took the form primarily of large-scale public-works projects. This, conveniently, was to the benefit of the LDP, which ensured that credit for public-works spending in its electoral districts was garnered by LDP members as evidence of their "pipeline" to the center. It also benefited the construction companies, who consistently were able to inflate profits through collusive bidding practices (Woodall 1992, 1996; MacCormack 1996). The enormous expenditure on these pork-barrel projects tended strongly to reinforce the old patterns of local subservience to central decision-making, as municipal governments scurried to Tokyo to gain their share of the spoils (Fukui and Fukai 1996). As shown by Alain Schebath (see Chapter 4), the huge public-works spending further reduced local autonomy by putting local governments ever deeper into debt, as most of the money spent on such pump-priming projects was provided by increased borrowing by municipal governments, and only a small share came from grants.

One important consequence of centralization in Japan, therefore, has been the 
creation and perpetuation of an unhealthy system of local political dependence on the center, accompanied by pervasive corruption in public-works contracting. This system is widely associated with Japan's current political gridlock and the economic stagnation that has continued since the early 1990s. The long-standing dominance of the center also has had a profound influence on local governance and associational life, both positive and negative.

\section{Social capital, civil society, and neighborhood associations}

It is clear from the preceding discussion that Japan has long had a highly centralized system, particularly with regard to local governance, land-development control, public works, and city planning issues. It is worth considering what the role of citizens, communities, and grassroots organizations in local environmental management has been in this context. While Japan is described by some scholars as having had a very weak civil society at least until the 1990s (Yoshida 1999; Yamamoto 1999; Vosse 1999), others have argued that the nation is the epitome of a high-trust, high social-capital society in which citizen associations are both numerous and significant (Vogel 1979; Fukuyama 1995). The case of local environmental management helps to clarify this apparent contradiction, as it makes the conflicts between top-down governance and bottom-up aspirations particularly apparent. The traditions and structures of local associational activity also provide an essential key to understanding contemporary processes and potentials for decentralization and local governance. This section examines the roles of communities in bottom-up urban-space management during the twentieth century, with particular attention to the roles of local groups such as neighborhood associations.

There is no doubt that the concepts of community, neighborhood, and village are central to understanding Japan. Many prominent Japanese sociologists have argued that the village community has been a crucial generative factor in the formation of Japanese society (Satô 1990; Fukutake 1982, 1967; Nakane 1990). A major reason, it is suggested, is that during the Tokugawa period about 80 percent of the population consisted of peasants living in rural villages (Satô 1990: 37), and even at the beginning of the 1920s only about 16 percent of the country was urbanized. The large-scale rural to urban migration that occurred during the twentieth century resulted in a majority of "urban" residents who, in fact, had grown up in rural villages. In 1940, when the share of urban population was approaching 40 percent, eight out of ten city residents had grown up in a village (Fukutake 1982: 33). Village traditions of self-governance and mutual aid, it is argued, in this way continued to inform urban social mores until well after the end of World War II. As discussed below, however, other scholars suggest that state policies also played an important role in mediating the specific forms that self-governance and cooperation took during the twentieth century.

Several features of the social and governing structure in villages are commonly held to have had important and lasting effects on Japanese society. First, villages in the feudal period were largely self-managing and self-policing, and 
were mostly left to their own devices as long as they paid their taxes and did not challenge the authority of those above. Villages were responsible for their own local infrastructure, such as roads, paths, irrigation systems, and maintenance of common forestlands. Paddy irrigation systems in particular required close cooperation of the village as a group, as the water supply normally had to be used sequentially by different areas, and coordinated carefully with tilling and planting cycles. These conditions undoubtedly fostered strong traditions of village social organization and cooperation. Second, the main taxation unit was the village, which was responsible collectively to pay its taxes, usually in rice. This tended to encourage both cooperation and mutual surveillance, as the failure of one family's crop for whatever reason would result in greater burdens for other families (Nakane 1990: 224).

These traditions of village self-governance and mutual support acquired an increasingly heavy patina of ideological significance during the process of modernization at the end of the nineteenth century and beginning of the twentieth. There had long been a degree of idealization of agriculture inherent in the neoConfucianism promoted by the Tokugawa ruling class during the Edo period; the tillers of the soil were the bedrock of the nation, creating both food and wealth, and maintaining the ancestral connection to nature and the eternal values of honest work and cultivation of the land. A popular movement promoting those values had flourished during the Edo period, inspired by the writings of Ninomiya Sontoku (1787-1856), and manifested in the formation of agricultural improvement societies (called hotokusha) in villages throughout the country in the nineteenth century. During modern times, as in the Edo period, the state tolerated and even encouraged such associations because of their contribution to the goals of stabilizing village life and strengthening the foundations of the state. National support of traditional agrarian values gained a new salience during the early decades of the twentieth century, as rapid urban industrialization and growing social conflict contributed to concerns that traditional attitudes of deference to authority and self-sufficiency might be yielding to increased individualism and tendencies toward materialism or, worse, socialism. By promoting the idea that rural villages were bastions of communal spirit and purity compared with the cities, Japanese authorities were endorsing Japan's "beautiful traditions" of village cooperation and mutual support (Gluck 1987: 178). Village solidarity, self-reliance, and mutual support were also seen as forming a key bulwark in the struggle against the social fragmentation and anomie believed inevitably to accompany modernization and urbanization, a change associated by the Japanese oligarchy with political unrest and radicalism (Smith 1978). Similarly, Japanese social theorists embraced German sociologist Ferdinand Tönnies' distinction between the traditional Gemeinschaft of the organic village and the Gesellschaft of the anonymous city, and sought ways to protect the former from the latter. Indeed, the idealization of the organic village persists today throughout Japanese culture, from the widespread promotion of furusato (literally, "my home town") (Robertson 1991) to the romanticization of traditional village life in the animated films of Miyazaki Hayao.

Village self-government did not necessarily imply internal village democracy 


\section{Sorensen}

and equality, however, and, in fact, status divisions within villages became increasingly wide as a consequence of population growth during the Tokugawa period (Nakane 1990: 216). Whereas the ideal was that villages were composed of farmers who were equal in status, in practice the families resident in the village longest tended to have preferential access to the limited resources of irrigation water and common property. The later nineteenth century in particular saw a steady concentration of landholdings as poor farmers were forced to mortgage or sell land to more prosperous landowners, and this in turn led to increasing conflicts between tenants and landlords in the early twentieth century (Francks 1984; Waswo 1977; Smethurst 1986). The wealthier owner-farmers controlled the village administration, chose the holders of village office, and exercised authority over precious water resources (Nakane 1990: 223), while tenant farmers contributed to taxes and the corvée through their rent (which tended to be about half of their crop) but had little influence in village affairs. Village meetings were attended by household heads, rather than by assemblies of all adults in the community. Today, this is still the most common practice in rural villages as well as in urban neighborhood associations. According to Nakane Chie, it

has been a factor hindering the wife from playing a more significant role in society. Japanese society does not resist the active participation of women in its activities so much as it has difficulty seeing any need for women to become involved when the husbands are already taking part.

(Nakane 1990: 226)

In practice, most villages tended to become highly stratified, with the wealthier members at the top of a well-understood hierarchy, able to wield considerable power over village affairs and expected to provide paternalistic support for the poorer members of the village in hard times. Such support was not always forthcoming, however, and high taxes, lack of land, and periodic crop failures meant that the lot of the rural poor was often one of grinding poverty. The desperation of small farmers was a prominent cause of the frequent peasant uprisings and riots during the Tokugawa period, which often targeted wealthy landlords and rice merchants as objects of their protests (Walthall 1991; Koschmann 1978).

In urban areas associational activity developed along similar lines. During the feudal period urban neighborhoods were responsible for their own self-governance, maintenance of streets, drainage ditches and canals, wells, garbage disposal, manning of neighborhood watch houses, fire patrol, local relief for the poor, and the organization of local festivals. These also had a clear status hierarchy with a small number of landowners at the top and large numbers of tenants at the bottom. Each neighborhood had its chief (nanushi), a position that was generally inherited, who was responsible for ensuring that laws were obeyed, taxes collected, firefighting squads organized, property transfers recorded, and guardhouses staffed. The chiefs relied on the further subdivision of the neighborhoods into five-family groups (goningumi), which consisted only of property owners and landlords' agents, not the tenants, who were represented by the agents. Order was maintained primarily 
by a mutual responsibility system for taxes and misdemeanors in which all members of the group were responsible for the transgressions of the others. As in rural areas, self-governance was more a matter of being left to take care of virtually all public services at the level of the individual neighborhood than a question of political autonomy, of which there was none. Nor did the payment of taxes imply any claim on the government apart from defense and the administration of justice (Sorensen 2002: 20).

The necessity of neighborhood self-organization to provide almost all necessary public services during two centuries of internal peace and urban economic growth did, however, have some positive outcomes: it reinforced the habit of self-sufficiency and contributed significantly to the development of social capital through traditions of self-organization and self-responsibility. The Japanese people thus entered the modern period with ample reserves of social capital and a flair for associational life. Carol Gluck details the long list of associations commonly found in rural villages, including agricultural, youth, army reserve, veterans', school, women's, and self-government associations (Gluck 1987: 198). Many of these had come together voluntarily on the basis of local needs and desires. Others were organized from above, as described below.

In the cities, with the transition to a modern national government at the end of the nineteenth century, the traditional urban governance structure of city elders, chiefs, and goningumi was abolished, and municipal governments were established to take over a number of the essential functions they had performed, such as tax collection, population registers, firefighting, and policing (Dore 1968: 187). At the same time, local governments had negligible funds, few taxation powers, and little ability or inclination to take over the many services that neighborhoods were already effectively providing for themselves. On the contrary, with modernization, the range of responsibilities delegated to local neighborhoods to undertake on a voluntary basis continued to grow, often as a result of directives by higher levels of government. For example, in 1900 Tokyo prefecture passed a law that required each neighborhood to set up a sanitation committee to prevent the spread of disease by ensuring that water and wastewater were adequately treated and by carrying out vaccination campaigns and a semiannual spraying of insecticides (Hastings 1995).

Certainly the most important examples of urban groups are the various neighborhood associations (referred to as chôkai, chônaikai, or jichikai). Although these came to fulfill many of the functions of the neighborhood organizations of the feudal era, there is little evidence of any direct connection with them, and in fact a survey conducted in 1925 by the Tokyo Institute for Municipal Research showed that 94 percent of the groups had been established since 1898, 30 years after the end of the feudal period (Narumi 1986: 63; Hastings 1995: 73). The formation of neighborhood associations increased rapidly after the Great Tokyo Earthquake of 1923 when local government services had virtually collapsed, so that by the time of the 1925 survey over 80 percent of households in Tokyo were claimed by associations to be members. It is also generally agreed that they were not initially directly a creation of government, but were voluntarily established 


\section{Sorensen}

by local residents in response to a need for local public services that were not routinely provided by municipal governments in the prewar period (Smith 1978; Hastings 1995). The associations were seen as necessary and useful by citizens, and they spread rapidly throughout Tokyo and the other large cities.

The general form of the associations followed the arrangements and territories set out for the sanitation committees in 1900. Notably, the membership automatically included all household heads within each neighborhood - another way the groups differed from the feudal neighborhood associations, which did not include tenants as members. As they became established, these neighborhood associations gradually absorbed the responsibilities of other local groups, such as the sanitation committees and local shrine associations. By the 1930s they had spread to cities throughout the country, with virtually every urban area divided into neighborhoods of 100 to 200 families. Their main activities were to organize local garbage-collection points and recycling activities, sanitation and insecticide campaigns, street cleaning, installation and maintenance of streetlights, night watches against fire and crime, local information dissemination through circulating notice boards, shrine support and local festival organization, and providing small gifts to local families celebrating a wedding or mourning a death. The majority of the leadership of neighborhood associations was drawn from the old urban middle class, especially the local landowners and shopkeepers, who most desired and benefited from the activities of the association, which improved the attractiveness of their area (Hastings 1995: 80).

During the period between the end of the Russo-Japanese War in 1905 and the beginning of the war in China in the early 1930s, the growth of the economy and the strengthening of Japanese democracy were accompanied by a significant expansion of civil society and the number and variety of independent organizations started to grow. The spread of popular protest movements, increasing labor and social activism, and a growing professional and middle class each contributed to the development of civil society. The Taisho period (1912-26) has been described as a time of rapid growth of civil society, coming between the authoritarianism of the Meiji period and the militarism of World War II (Iokibe 1999: 75). To a certain extent, urban neighborhood associations contributed to this growth of civil society. For example, even though they were closely allied to local governments, they not infrequently opposed specific planning policies.

The neighborhood associations were clearly useful to the state and, even though they may have initially formed voluntarily, over time the state increasingly co-opted them. Such efforts intensified after the Russo-Japanese war ended in 1905, as Japanese leaders grew increasingly worried about the adverse social impacts of industrialization and urban growth, particularly as with success in war the national project shifted from the widely supported goal of national preservation in the face of foreign expansion to one of imperial expansion on the Asian mainland (Harootunian 1974; Oka 1982). After this period the state became increasingly involved in efforts to mobilize the Japanese population in support of imperial policies of military expansion and economic growth. This was essentially an ideological project, which consisted of attempts to bring local areas within 
the ideological influence of the center (Gluck 1987: 191). As Kenneth Pyle has shown, the first major campaign was the "local improvement movement" of the first two decades of the twentieth century, which sought to organize existing rural grassroots associations, such as the army reservist clubs, women's associations, community credit societies, young men's groups, and agricultural-improvement associations into national hierarchical structures designed to disseminate government messages encouraging local self-help and mutual support groups in rural areas (Pyle 1973). Gluck argues that it was precisely because of the strong capacity of Japanese communities to establish flourishing voluntary associations that the government was able to create national hierarchical organizations with such ease (Gluck 1987: 198). Many of the associations enrolled by the Home Ministry, the army, and the Ministry of Agriculture in national leagues had already formed their basic units at the village level. It was then a relatively easy task to persuade the leadership of existing associations to join national structures, as these promised significant rewards of legitimacy, official recognition, and networking opportunities in larger political structures. National ministries in this way created national organizations and an effective means of disseminating information to villages throughout the country, although, as Princeton historian Sheldon Garon points out, they did not necessarily gain complete control over local groups, which often had their own ideas (Garon 2003).

The national ministries attempted to promote three main messages: first, that Japan's main resource was its people, and it could not hope to compete with the Western powers unless it developed a unity of spirit in support of national goals; second, that each citizen's responsibility was to work hard, live frugally, pay taxes, and save money to support national development; and third, that local governments and villages were to administer their own affairs efficiently to eliminate waste and duplication and reduce the burden on central government. A major element of such improved efficiency was to be the merging of small villages and hamlets into larger administrative units, along with the amalgamation of Shinto shrines and the reduction of wasteful spending on festivals, alcohol, and tobacco (Pyle 1973; Gluck 1987; Garon 1997).

It is likely that the initial intent of many local bureaucrats was merely to support such beneficial organizations. As Sally Anne Hastings argues,

the municipal government strongly endorsed the concept of neighborhood associations. It used the associations to carry out certain of its own polities. The associations did not, however, become arms of either the municipal or national government until after the outbreak of war with China ... the government was becoming involved in the concerns of the associations, which is quite different from the associations becoming the creatures of the government.

(Hastings 1995: 85)

Many local and national government bureaucrats made sincere efforts to work with local communities to alleviate poverty, ameliorate living and housing conditions, 


\section{Sorensen}

provide better community services, and mobilize the voluntary activities of local citizens to improve the health and welfare of urban citizens (Garon 1997; Hastings 1995; Hanes 2002). An important example of this strategy was the system of voluntary "welfare commissioners" (minsei-iin) that was established by the Home Ministry throughout the country during the 1920s. Following the pattern of the German "Elberfeld System," affluent and prominent members of each neighborhood were enlisted to provide advice, encouragement, employment contacts, and introductions to appropriate municipal services to help poorer residents get back on their feet (Ikeda 1986). This system cost the government little and reinforced the importance of self-reliance. The commissioners were often also active in the leadership of the neighborhood associations, as both drew primarily from the local middle class (Steiner 1965: 221).

State-directed efforts to shape the development of national associational activity did, however, steadily increase the links between national ministries and local actors, and helped to blur the separation between civil society and the state. A first step was to form them into ward $(k u)$-level leagues with space in the ward office and led by the ward head. By 1935, 15 of the 35 wards in the city of Tokyo had established such networks of associations (Hastings 1995: 84). During the 1930s the neighborhood associations were gradually transformed into an effective link from central government ministries to every community and virtually every home in the country, providing an impressive means of social control. In 1940 the Home Ministry made neighborhood associations compulsory for the whole country and formally incorporated them into the local government system, giving them the additional responsibilities of civil defense, distribution of rations, and the promotion of savings, creating an efficient system for gathering information on deviant behavior and political dissent. This system was extremely effective at exerting pressure on families and individuals, and was exploited to the full during wartime (Dore 1958: 272).

It is clear that as Japan slipped deeper into total war during the 1930s and early 1940s the space for autonomous civil society grew progressively smaller. Garon cautions, however, that the standard division of the interwar period into the "Taisho Democracy" period, marked by a rapid expansion of civil society until the early 1930s, and a wartime period from 1931 to 1945 in which civil society was progressively eliminated, although perhaps a useful shorthand, exaggerates on both counts. The period of the blossoming of civil society was also one in which the state increasingly incorporated formerly independent associations into its networks and broadened its capacity to shape the development of associational activity. In the wartime period also, while the state was effective in disbanding almost every autonomous grouping, or reorganizing them into state-run organizations, the momentum and societal knowledge gained during the Taisho period was not lost entirely, and many of the individuals and organizations thus co-opted into the state still had an influence on its policies (Garon 2003: 51-6).

Undeniably, there was considerable movement toward democratization in postwar Japan. Although it is true that the American-led occupation imposed democracy from above, many Japanese seized the opportunity with great energy 
and determination, unleashing an outpouring of energies directed both at rebuilding the country and at creating new political institutions (see Dower 1999). At the national level the legalization of leftist political parties allowed the Japanese Socialist Party and the Japan Communist Party (JCP) to win a major share of the vote, and even form a coalition government under Socialist Prime Minister Katayama Tetsu for nine months during 1947-8. There was also clearly a significant reemergence of civil society, with the legalization of labor organizing, the rapid growth of union membership, and the rise of interest groups of all sorts. It is true that the "reverse course" of the occupation, which reinvigorated Japanese conservatism's traditional anticommunism with American Cold War convictions, had a powerful impact on the political balance of power, especially with the purges of alleged communists in the labor movement and the media in the early 1950s. But many of the gains were permanent, and contributed to the gradual development of democracy and civil society in postwar Japan.

Perhaps the most dramatic evidence of the expansion of political freedom and civil society consisted of the opposition movements against the remilitarization of Japan during the 1950s, which culminated in massive demonstrations against the revision of the security treaty with the United States (the so-called ANPO treaty) during the spring of 1960, in which thousands protested the renewal of the treaty and the conservative government's "undemocratic" tactics used to push it through the legislature. This was an unprecedented expression of political independence. As Berkeley historian Andrew Barshay puts it:

The galvanized and convergent energies of a range of quite disparate social groups, the huge scale and variety of the protests, the sense that individual commitment and engagement need not come at the price of ideological subordination to any party - all this was new. This was civil society.

(Barshay 2003: 71)

In another sense, however, ANPO demonstrated the great weakness of Japanese civil society, as after the storm of protest had melted away few enduring organizational structures remained. The Left backed away from direct confrontation with the state, and the conservative government shifted its tactics toward an increased emphasis on rapid economic growth. At the local level virtually all prefectural and municipal governments were controlled by conservatives, who used their political dominance and the consensus on economic growth to pursue the developmental state project. The neighborhood associations, which had been banned by the occupation as a manifestation of the intrusive and antidemocratic reach of the state into everyday life, gradually reestablished themselves, often with slightly different names but mostly with the same boundaries and structure and frequently under the same leadership (Dore 1958).

The role of the neighborhood associations in local political development during the postwar period has been much debated. On the one hand, many saw them simply as a manifestation of the old domination of local conservative elites, as stable electoral bases used by local bosses to deliver safe blocks of votes at elec- 


\section{Sorensen}

tion time in return for political connections (Steiner 1965: 227). For others the neighborhood associations were a reflection of strong community social capital, which when needed could be mobilized for other than conservative purposes (Nakamura 1968; Munger 1976; White 1976). In fact, these contradictory views of neighborhood associations are probably both true, as there is considerable variation between places and different times.

Probably most revealing of the contradictory faces of neighborhood associations were their varied responses to the environmental crisis of the 1960s. As is well known, rapid economic growth during the 1950s and 1960s in a context of weak to nonexistent pollution control regulations, and high-density urban areas where industry was tightly interwoven with residential and commercial areas, resulted in a pollution disaster. Hundreds died and thousands were crippled and made ill, with official status as pollution victims (entitling citizens to relief and medical aid) granted to more than 73,000 people by 1979 (McKean 1981: 20). One of the most shocking aspects of the pollution crisis was that for years the state sided with the corporations against the pollution victims, concealing evidence that linked particular polluters to clusters of illness, shutting down university research projects, and blocking attempts to make polluters accept responsibility (Ui 1992; Reich 1983; Upham 1987). Initially, conservative control over local politics continued to dominate, with many of those most affected being shunned for their attempts to make their problems public through protests (Iijima 1992). As problems worsened, however, many communities whose members were sick or dying became more militant; traditional constraints were thrust aside and a variety of direct-action protest techniques were employed. Eventually, as the extent of the problems became better known, and in particular as the anti-pollution movements grew and began to experience some success in proving the damage to human health that industrial pollution was causing, the tide of public opinion began to turn. Thousands of anti-pollution movements were formed throughout the country in what Ellis Krauss and Bradford Simcock (1980: 196) describe as a "veritable explosion of protest in urban and suburban areas." In 1971 alone local governments received 75,000 pollution-related complaints, and there were as many as 10,000 local disputes in 1973 (Krauss and Simcock 1980).

Here the most important aspects of the anti-pollution movements are the contradictory roles of neighborhood associations, and the fact that most of the citizen movements remained small and tended to have a short lifespan, either collapsing after defeat or disbanding after victory. While it might have been expected that the neighborhood associations would have been in the forefront of organizing to prevent pollution disasters, most research shows that the exact opposite was the case. In the vast majority of instances neighborhood associations were dominated by conservative leaders, and were much more likely to block efforts to oppose pollution problems than they were to support them. Political scientist Margaret McKean, who has produced some of the most authoritative research on antipollution citizen movements, put it this way:

For the most part, attempts to use the formal institutions or networks which monopolized communal activity in Japan . . f failed. Political parties had no 
mass base. Agricultural cooperatives, neighborhood associations, candidate support organizations, and similar groups that ordinarily served as intermediaries between citizens and political institutions were unresponsive or even hostile to the pollution issue. Only in the rare situation where pollution threatened all members of a preexisting group equally ... did these organizations perform the function of political intermediary.

(McKean 1981: 225)

Not only did most neighborhood associations fail to support local efforts to protest pollution problems but they also helped to block the development of alternative groups, at least temporarily, as they had a monopoly on local connections and legitimacy. Only the most determined activists were able to get around their neighborhood association and establish a separate group. As a result, a majority of new citizen movements of the 1960s were formed outside and often in opposition to their neighborhood association. In newly built areas where the conservative elite was not so entrenched, neighborhood associations were much more likely to serve as a vehicle for protest (McKean 1981: 226; Nakamura 1968). An excellent example of such a case is provided by anthropologist Eyal Ben-Ari (1991) whose study of a new suburban development outside Kyoto demonstrates that a neighborhood association can be an effective model for civic activism when it is not dominated by entrenched elites.

Certainly the most profound study of the contradictory roles of neighborhood associations in local political conflicts is sociologist Jeffrey Broadbent's detailed examination (1998) of the clash over the New Industrial City project in Oita prefecture during the 1970s and 1980s. The prefectural government had initiated and promoted a large-scale industrial development, and many local groups were strongly opposed to a project that they felt would destroy their communities and fishing grounds. Broadbent shows in detail how central government ministries, the prefectural government, municipal governments, LDP politicians, and local bosses worked together to overcome that opposition. Where a strong leader emerged who was opposed to the development project, he was usually able to mobilize the psychological and material resources of the community to create a strong and determined opposition movement. On the other hand, the role of the leader was decisive, and where the leader faltered, or was co-opted or bought out, the movement usually collapsed. In some cases neighborhood associations created avenues to mobilize opposition, and in other cases they helped to block the formation of opposition citizen movements, and also served as useful channels of influence for those hoping to defeat or co-opt the movement (Broadbent 1998).

The question remains: Why did most of the citizen movements remain so small and short-lived? As McKean and others have noted, Japanese anti-pollution movements of the 1970s, although as large in numbers of participants as their contemporaries in the United States, did not produce a single national organization on the scale of the Sierra Club or the National Wildlife Federation (Broadbent 1998: 286). These large, well-resourced, and professionalized American organizations have been able to exert political pressure on governments, generate their own research and publicity, and keep environmental issues alive in the public debate. 
In Japan, on the other hand, the environmental movement almost disappeared during the 1980s, with only sporadic flare-ups over specific local issues since that time. That was only partly due to the success of the pollution-prevention laws of the early 1970 s.

University of Washington political scientist Robert Pekkanen has persuasively argued that the state has had a powerful impact on the patterns of civil society development in Japan during the postwar period by promoting some types of groups and hindering others. According to his analysis, "small, local groups such as neighborhood associations have been promoted by the state; large, independent professionalized groups such as Greenpeace have faced a much more hostile legal environment" (Pekkanen 2003: 116). Pekkanen does not suggest that large professional groups are either better or more important than small neighborhood groups, but that they perform quite different roles and have different capacities to influence politics and policies. Whereas "small, local groups can contribute to stocks of social capital and perhaps to the performance of local governments ... professionalized groups that have a large core of full-time employees can develop expertise, institutionalize movements, and influence policies and other outcomes down the road; they change the political landscape" (Pekkanen 2003: 117).

The state influenced the development of postwar Japanese civil society in three main ways. First, the state actively worked to establish semi-independent nonprofit organizations in particular sectors. In fact, a majority of Japanese nonprofit organizations (NPOs) were created by the government to carry out various state-delegated functions. Thus, although the established NPO sector in Japan is actually very large in comparative terms, being second only to that of the United States in total spending, this is primarily because most universities, hospitals, and welfare centers are registered as NPOs. As Wilhelm Vosse has shown:

To a large degree, the private nonprofit sector has taken over responsibilities formerly covered by the state, and the vast majority of these nonprofit institutions have no relationship to grassroots civic groups. Subsectors concerned with the natural environment, civil advocacy, philanthropy, as well as international exchange and cooperation had an almost negligible share of the nonprofit sector.

(Vosse 1999: 37)

Whether these state-sponsored NPOs qualify as part of civil society or not is open to debate (see Salamon and Anheier 1997), but it seems very likely that because of their size and dominant position they would have a major impact within their sphere.

Second, the postwar state provided smaller organizations, especially the neighborhood associations, with significant benefits in terms of legitimation, de facto legal recognition, and a monopoly over certain functions within each neighborhood. Third, it tightly regulated the granting of legal status to larger organizations (Pekkanen 2003: 125). The support for neighborhood associations, discussed above, contrasted with the obstacles that hindered the development of large, 
professionalized civil society organizations. Until the NPO Law was passed in 1998, it was difficult for NPOs to gain legal status, the granting of which was the responsibility of the various national ministries within their area of jurisdiction. Without legal status, it is very difficult to operate in Japan; space cannot be rented, bank accounts cannot be established, and staff cannot be hired, so organizations unable to attain legal nonprofit status must either remain small and informal or register as for-profit corporations. Not only did the ministries have quite a wide degree of discretion in whether to grant legal status to NPOs, they also commonly required that groups have a minimum of $\$ 3$ million in assets before being given such status. This almost certainly prevented many potential groups from gaining legal status. Furthermore, many groups interested in environmental advocacy, for example, found that they did not fit neatly within the jurisdiction of one ministry, and had great difficulty gaining legal recognition. Those groups that did manage to raise sufficient funds and fit within the jurisdiction of a ministry still found that because of the wide discretion of the ministries to refuse their application, they commonly had to accept the placement of retiring ministry bureaucrats on their board of directors, and could not easily ignore ministry guidance (Pekkanen 2003; Kawashima 2001; Yamamoto 1999). Ministries also tended to define the permitted range of activities of organizations quite narrowly, and activities outside those permitted could result in dissolution. In short, the powers of the central bureaucracy over NPOs were broad, and it is no coincidence that so few large-scale NPOs developed. Even today, although Japan clearly has a vibrant civil society, most civil society organizations are small, without significant financial resources, and have few paid staff members.

These restrictions on the legal status of civil society organizations are apparent in the machizukuri movements advocating local environmental management, which spread throughout Japan during the 1990s. Most of these groups are extremely small, and operate without staff or legal status. As with the earlier anti-pollution citizen movements, in many cases lack of support from neighborhood associations has meant that machizukuri movements (further discussed in Chapters 6 and 7 by Watanabe Shun-ichi and Christoph Brumann respectively) have organized independently, although in some cases machizukuri groups have grown out of neighborhood associations as subcommittees (Tominaga 2001).

\section{Conclusions}

There are four main points that can be drawn from this history. First, the Japanese case makes abundantly clear that a distinction must be made between social capital and civil society, two concepts that are often poorly differentiated in recent literature. The long and vital tradition of local self-help and strong neighborhoods clearly fostered strong stocks of local social capital. This was partly a grassroots response to local needs and priorities, but was also actively promoted by the state as a way of unifying and mobilizing the population. Japanese communities clearly demonstrate very high levels of associational activity and an ability to organize and maintain large numbers of local voluntary institutions. Many, though by no 


\section{Sorensen}

means all, of these are still based in communities of place - urban neighborhoods that often still have the same boundaries that were established in the early part of the twentieth century. Participation rates are high, neighbors know one another, and the eyes-on-the-street approach to local security is still effective. This high level of social capital has not been associated with a strong civil society, however, which is still in the process of developing today. Not only did strong social capital not result in an effective civil society that could serve to balance the power of the state, but in the prewar period neighborhood associations were incorporated into the totalitarian apparatus of the state, and in the postwar period they often helped to block the development of movements in opposition to state policies. Janet Abu-Lughod and others have argued that, despite its recent popularity as a solution to all sorts of urban problems, civil society is not necessarily a progressive force (Abu-Lughod 1998). The same must be said of social capital: while it may aid community organizing, such mobilization can lead in a variety of directions, depending on the circumstances. The Japanese case clearly shows that it is possible to have rich social-capital resources at the same time as a weakly developed civil society.

This observation gives rise directly to the second point: the state can have a powerful role in shaping the patterns of development of civil society organizations. Japan's highly centralized system has worked to shape the organizational structures as well as the resources available to and the opportunities for civil society organizations in Japan. Legal restrictions on nonprofit organizations have limited the growth of associations into large-scale professionalized organizations while encouraging small-scale neighborhood groups. This seems to have had a significant impact on both the longevity of organizations and the kinds of activity in which they can effectively engage. To influence national government policies takes significant resources and a long-term view. In the case of Japan, as most civil society groups have been relatively small, and the planning system highly centralized, these associations have had great difficulties in influencing planning policy.

Third, civil society organizations have had an important but highly structured role in Japanese urban governance. In the prewar period neighborhood associations were arguably the main civil society actors engaged in urban governance. They contributed primarily by fostering the development of strong stocks of social capital and by relieving local governments of responsibility for a wide range of public services, which were provided by local people on a voluntary basis. Neighborhood associations appear to have achieved little input into policy, and were incorporated into the state during the war. In the postwar period their roles became more complex. On the one hand, they were commonly used by conservative elites as a base of local political influence, and they often had the effect of blocking at least temporarily the development of groups with other priorities. For example, in most cases the neighborhood associations opposed the anti-pollution movements, which had to form their own independent groups. The pollution crisis was so severe, however, that large numbers of new local citizen movements developed, helping to change the political balance of power and forcing both local 
and national governments to make major policy changes. They did not, however, then grow into the kinds of large-scale professional organizations, such as the Sierra Club or Greenpeace, that took hold in other developed countries, apparently because of a restrictive legal framework. The role of civil society actors in urban governance during the postwar period appears to have been much more limited than in most of the other developed countries. Instead, the recent wave of citizen activism around local environmental issues in the 1990s, referred to as machizukuri, once again started at the scale of small, local neighborhood-based citizen movements. While the rapid proliferation of local machizukuri groups is yet another sign of vitality at the local level, the real question may be whether organizations will materialize that have the scale, resources, technical competence, and political weight needed to effect a real impact on policy-making at the national level. It remains to be seen whether the changes to the NPO Law will allow some machizukuri movements to grow and contribute to the emergence of a more institutionally developed and politically powerful civil society.

Finally, the small scale and lack of resources of civil society organizations seems certain to make the process of decentralization slower, more difficult, and less effective than might have been the case if a broad range of such organizations already existed. There is considerable evidence that since the passage of the NPO Law in 1998 there has been real growth in the sector, but it will take years to develop the wide range of sophisticated organizations seen in most other developed countries. This is important, because the process of decentralization elsewhere has often been not simply from central to local governments but also from central and local government to the volunteer and nonprofit sector. For this to be a real decentralization of governance structures, and not merely the old style of task delegation to junior entities without the opportunity for input into policy formation or decision-making, a strong, well-resourced, professionally staffed civil society sector will be invaluable.

\section{References}

Abu-Lughod, Janet (1998) "Civil/Uncivil Society: Confusing Form with Content," in Mike Douglass and John Friedmann (eds.) Cities for Citizens: Planning and the Rise of Civil Society in a Global Age, Chichester: John Wiley \& Sons, pp. 227-37.

Allinson, Gary D. (1997) Japan's Postwar History, Ithaca, NY: Cornell University Press.

Barshay, Andrew (2003) "Capitalism and Civil Society in Postwar Japan: Perspectives from Intellectual History," in Frank J. Schwartz and Susan J. Pharr (eds.) The State of Civil Society in Japan, Cambridge: Cambridge University Press, pp. 63-80.

Ben-Ari, Eyal (1991) Changing Japanese Suburbia: A Study of Two Present-Day Localities, London: Kegan Paul International.

Borja, Jordi and Castells, Manuel (1997) Local and Global: Management of Cities in the Information Age, London: Earthscan.

Broadbent, Jeffrey (1998) Environmental Politics in Japan, Cambridge: Cambridge University Press.

Calder, Kent E. (1988) Crisis and Compensation: Public Policy and Political Stability in Japan, 1949-1986, Princeton, NJ: Princeton University Press. 


\section{Sorensen}

Castells, Manuel (1997) The Power of Identity, vol. 2, Information Age: Economy, Society and Culture, Cambridge, MA: Blackwell.

Chihô bunken suishin iinkai (Local Rights Promotion Committee) (1997) "Daiichi kankoku: bunken suishinkata shakai no sôzô" (First report on the social structure to promote decentralization), Tokyo: Government of Japan (Gyôsei).

Dore, Ronald P. (1958) City Life in Japan - A Study of a Tokyo Ward, London: Routledge and Kegan Paul.

_ (1968) "Urban Ward Associations in Japan - Introduction," in Raymond E. Pahl (ed.) Readings in Urban Sociology, Oxford: Pergamon, pp. 186-90.

Dower, John W. (1999) Embracing Defeat: Japan in the Wake of World War II. New York: W.W. Norton \& Company/The New Press.

Francks, Penelope (1984) Technology and Agricultural Development in Pre-War Japan, New Haven, CT: Yale University Press.

Fukui Haruhiro and Fukai Shigeko N. (1996) "Pork Barrel Politics, Networks, and Local Economic Development in Contemporary Japan," Asian Survey 36(3): 268-86.

Fukutake Tadashi (1967) Japanese Rural Society, Ithaca, NY: Cornell University Press.

- (1982) The Japanese Social Structure, Tokyo: University of Tokyo Press.

Fukuyama, Francis (1995) Trust: The Social Virtues and the Creation of Prosperity, New York: Simon \& Schuster.

Garon, Sheldon (1997) Molding Japanese Minds: The State in Everyday Life, Princeton, NJ: Princeton University Press.

- (2003) "From Meiji to Heisei: The State and Civil Society in Japan," in Frank J. Schwartz and Susan J. Pharr (eds.) The State of Civil Society in Japan, Cambridge: Cambridge University Press, pp. 42-62.

Garon, Sheldon and Mochizuki, Mike (1993) "Negotiating Social Contracts," in Andrew Gordon (ed.) Postwar Japan as History, Berkeley, CA: University of California Press, pp. 145-66.

Gluck, Carol (1987) Japan's Modern Myths: Ideology in the Late Meiji Period, Princeton, NJ: Princeton University Press.

Hanayama Yuzuru (1986) Land Markets and Land Policy in a Metropolitan Area: A Case Study of Tokyo, Boston: Oelgeschlager, Gunn, and Hain.

Hanes, Jeffrey. E. (2002) City as Subject: Seki Hajime and the Reinvention of Modern Osaka, Berkeley, CA: University of California Press.

Harootunian, Harry D. (1974) "Introduction: A Sense of an Ending and the Problem of Taisho," in Bernard S. Silberman and Harry D. Harootunian (eds.) Japan in Crisis: Essays in Taisho Democracy, Princeton, NJ: Princeton University Press, pp. 3-28.

Hastings, Sally Anne (1995) Neighborhood and Nation in Tokyo, 1905-1937, Pittsburgh: University of Pittsburgh Press.

Hebbert, Michael (1994) "Sen-biki amidst Desakota: Urban Sprawl and Urban Planning in Japan," in Philip Shapira, Ian Masser, and David W. Edgington (eds.) Planning for Cities and Regions in Japan, Liverpool: Liverpool University Press, pp. 70-91.

Hebbert, Michael and Nakai Norihiro (1988) "Deregulation of Japanese Planning," Town Planning Review 59(4): 383-95.

Hunter, Janet E. (1989) The Emergence of Modern Japan: An Introductory History since 1853, London: Longman.

Iida Momo (1994) "The Fall of the 1955 System in Japanese Politics and the Current Crisis of Hegemony," Social Justice 21(2): 50-61.

Iijima Nobuko (1992) "Social Structures of Pollution Victims," in Jun Ui (ed.) Industrial Pollution in Japan, Tokyo: United Nations University Press, pp. 154-72. 
Ikeda Yoshimasa (1986) Nihon shakai fukushi shi (The history of Japanese social welfare), Kyoto: Horitsu Bunka Sha.

Iokibe Makoto (1999) "Japan's Civil Society: An Historical Overview," in Tadashi Yamamoto (ed.) Deciding the Public Good: Governance and Civil Society in Japan, Tokyo: Japan Center for International Exchange, pp. 51-96.

Ishida Yorifusa (1987) Nihon kindai toshi keikaku no hyakunen (The last 100 years of Japanese urban planning), Tokyo: Jichitai Kenkyusha.

Jansen, Marius B. and Rozman, Gilbert (1986) Japan in Transition: From Tokugawa to Meiji, Princeton, NJ: Princeton University Press.

Johnson, Chalmers A. (1986) MITI and the Japanese Miracle, the Growth of Industrial Policy, 1925-1975, repr. Tokyo: Tuttle.

Kawashima Nobuko (2001) "The Emerging Voluntary Sector in Japan: Issues and Prospects," International Working Paper 7, Centre for Civil Society, London School of Economics.

Kobayashi Shigenori (ed.) (1999) Chihô bunken jidai no machizukuri jôrei (Local community-building ordinances in the era of local rights), Kyoto: Gakugei Shuppansha.

Koschmann, J. Victor (1978) Authority and the Individual in Japan: Citizen Protest in Historical Perspective, Tokyo: University of Tokyo Press.

Krauss, Ellis S. and Simcock, Bradford (1980) "Citizens' movements: The Growth and Impact of Environmental Protest in Japan," in Kurt Steiner, Ellis Kraus, and Scott Flanagan (eds.) Political Opposition and Local Politics in Japan, Princeton, NJ: Princeton University Press, pp. 187-227.

Low, Nicholas, Gleeson, Brendan, Elander, Ingemar, and Lidskog, Rolf (eds.) (2000) Consuming Cities: The Urban Environment in the Global Economy after the Rio Declaration, London: Routledge.

MacCormack, Gavan (1996) The Emptiness of Japanese Affluence, Armonk, NY: M. E. Sharpe.

McKean, Margaret (1981) Environmental Protest and Citizen Politics in Japan, Berkeley, CA: University of California Press.

Mori Hiroshi (1998) "Land Conversion at the Urban Fringe: A Comparative Study of Japan, Britain and the Netherlands," Urban Studies 35(9): 1541-58.

Morimura Michiyoshi (1994) "Change in the Japanese Urban Planning Priorities and the Response of Urban Planners 1960-90," in University of Tokyo Department of Urban Engineering (ed.) Contemporary Studies in Urban Environmental Management in Japan, Tokyo: Kajima Institute Publishing, pp. 8-24.

Munger, Frank (1976) "Social Change and Urban Life: an Introduction," in James W. White and Frank Munger (eds.) Social Change and Community Politics in Urban Japan, Chapel Hill, NC: Institute for Research in Social Science, University of North Carolina at Chapel Hill, pp. 1-15.

Muramatsu Michio (1997) Local Power in the Japanese State, trans. Betsey Scheiner and James White, Berkeley, CA: University of California Press.

Nakamura Hachiro (1968) "Urban Ward Associations in Japan," in Raymond E. Pahl (ed.) Readings in Urban Sociology, Oxford: Pergamon, pp. 186-208.

Nakane Chie (1990) "Tokugawa Society," in Nakane Chie and Oishi Shinzaburo (eds.) Tokugawa Japan: Social and Economic Antecedents of Modern Japan, Tokyo: University of Tokyo Press, pp. 213-31.

Narumi Kunihiro (1986) "Metropolitan Neighbourhoods in Japan and the West: Nested Systems Versus Axial Systems," in Umesao Tadao, Henry D. Smith, Moriya Takeshi, 


\section{Sorensen}

and Ogawa Ryo (eds.) Japanese Civilization in the Modern World, vol. 2, Cities and Urbanization, Osaka: National Museum of Ethnology, pp. 59-76.

Oka Yoshitake (1982) "Generational Conflict after the Russo-Japanese War," in Tetsuo Najita and Victor J. Koschmann (eds.) Conflict in Modern Japanese History: The Neglected Tradition, Princeton, NJ: Princeton University Press, pp. 197-225.

Pekkanen, Robert (2003) "Molding Japanese Civil Society: State-Structured Incentives and the Patterning of Civil Society," in Frank J. Schwartz and Susan J. Pharr (eds.) The State of Civil Society in Japan, Cambridge: Cambridge University Press, pp. 116-34.

Pempel, Thomas J. (1998) Regime Shift: Comparative Dynamics of the Japanese Political Economy, Ithaca, NY: Cornell University Press.

Pyle, Kenneth B. (1973) “The Technology of Japanese Nationalism: The Local Improvement Movement, 1900-1918," Journal of Asian Studies 33(1): 51-65.

Reed, Steven R. (1986) Japanese Prefectures and Policymaking, Pittsburgh: University of Pittsburgh Press.

Reich, Michael R. (1983) "Environmental Policy and Japanese Society: Part I. Successes and Failures," International Journal of Environmental Studies 20: 191-8.

Robertson, Jennifer (1991) Native and Newcomer: Making and Remaking a Japanese City, Berkeley, CA: University of California Press.

Salamon, Lester M. and Anheier, Helmut K. (eds.) (1997) Defining the Non-Profit Sector: A Cross-National Analysis, Manchester: Manchester University Press.

Samuels, Richard J. (1983) The Politics of Regional Policy in Japan: Localities Incorporated?, Princeton, NJ: Princeton University Press.

Satô Tsuneo (1990) "Tokugawa Villages and Agriculture," in Nakane Chie and Oishi Shinzaburo (eds.) Tokugawa Japan: Social and Economic Antecedents of Modern Japan, Tokyo: University of Tokyo Press, pp. 37-80.

Shindô Muneyuki (1984) "Relations between National and Local Government," in Tsuji Kiyoaki (ed.) Public Administration in Japan, Tokyo: University of Tokyo Press, pp. 109-20.

Sitarz, Dan (1993) Agenda 21: The Earth Summit Strategy to Save Our Planet, Boulder, CO: EarthPress.

Smethurst, Richard J. (1986) Agricultural Development and Tenancy Disputes in Japan 1870-1940, Princeton, NJ: Princeton University Press.

Smith, Henry D. (1978) "Tokyo as an Idea: An Exploration of Japanese Urban Thought until 1945," Journal of Japanese Studies 4(1): 45-80.

Sorensen, André (2002) The Making of Urban Japan: Cities and Planning from Edo to the 21st Century, London: Routledge.

- (2003) "Building World City Tokyo: Globalization and Conflict over Urban Space," Annals of Regional Science 37(3): 519-31.

Steiner, Kurt (1965) Local Government in Japan, Stanford, CA: Stanford University Press.

Stren, Richard (2002) "Local Governance and the Development of Associational Life: An Exploration," in Joseph S. Tulchin, Diana H. Varat, and Blair A. Ruble (eds.) Democratic Governance and Urban Sustainability, Washington, DC: Woodrow Wilson International Center for Scholars, pp. 9-28.

Tominaga Kazuo (2001) "NPO-Fusion Nagaike," City Planning Review (Toshi Keikaku) 50(1): 92-3.

Ui, Jun (ed.) (1992) Industrial Pollution in Japan, Tokyo: United Nations University Press.

United Nations Department of Public Information (1993) Agenda 21: Programme of Action for Sustainable Development; Rio Declaration on Environment and Development; 
Statement of Forest Principles: the final text of agreements negotiated by governments at the United Nations Conference on Environment and Development (UNCED), 3-14 June 1992, Rio de Janeiro, Brazil, New York: United Nations Department of Public Information.

Upham, Frank K. (1987) Law and Social Change in Postwar Japan, Cambridge, MA: Harvard University Press.

Vogel, Ezra F. (1979) Japan as Number One: Lessons for America, New York: Harper \& Row.

Vosse, Wilhelm (1999) "The Emergence of a Civil Society in Japan," Japanstudien: Jahrbuch des Deutschen Instituts fur Japanstudien der Philipp Franz von Siebold Stiftung 11: 31-53.

Walthall, Anne (1991) Peasant Uprisings in Japan, Chicago: University of Chicago Press.

Waswo, Anne (1977) Japanese Landlords: The Decline of a Rural Elite, Berkeley, CA: University of California Press.

Watanabe Shun-ichi (2000) "Changing Paradigm of the Japanese Urban Planning System," paper presented at the European Association of Japanese Studies, Lahti, Finland, August.

Westney, D. Eleanor (1987) Imitation and Innovation: The Transfer of Western Organisational Patterns to Meiji Japan, Cambridge, MA: Harvard University Press.

White, James W. (1976) "Social Change and Community Involvement in Metropolitan Japan," in James W. White and Frank Munger (eds.) Social Change and Community Politics in Urban Japan, Chapel Hill, NC: Institute for Research in Social Science, University of North Carolina at Chapel Hill, pp. 101-29.

Woodall, Brian (1992) "The Politics of Land in Japan's Dual Political Economy," in John O. Haley and Yamamura Kozo (eds.) Land Issues in Japan: A Policy Failure?, Seattle: Society for Japanese Studies, 113-48.

(1996) Japan Under Construction: Corruption, Politics and Public Works, Berkeley, CA: University of California Press.

Yamamoto Tadashi (1999) "Emergence of Japan's Civil Society and its Future Challenges," in Yamamoto Tadashi (ed.) Deciding the Public Good: Governance and Civil Society in Japan, Tokyo: Japan Center for International Exchange, pp. 97-124.

Yoshida Shin'ichi (1999) "Rethinking the Public Interest in Japan: Civil Society in the Making," in Yamamoto Tadashi (ed.) Deciding the Public Good: Governance and Civil Society in Japan, Tokyo: Japan Center for International Exchange, pp. 13-49. 


\title{
6 Machizukuri in Japan \\ A historical perspective on participatory community-building initiatives
}

\author{
Watanabe Shun-ichi J.
}

In local communities throughout Japan today, machizukuri, or communitybuilding, is prevalent. Literally, machi means "community" and zukuri, "building," or "making," and this term is used to apply to a wide variety of activities. Government-sponsored road construction, citizen-led monitoring of municipal governance, the erection of apartment buildings by private developers, and even karaoke parties held by communities all often fall under the heading of machizukuri.

Although the theoretical study of machizukuri is only in its early stages, with a major shift of planning powers away from the Japanese national government to the local municipality in the context of political decentralization likely to occur in the twenty-first century, the impact of both the concept and the method of machizukuri on the future of every aspect of the urban planning system will be significant. As indicated, however, the concept of machizukuri is multifold, frequently made intentionally ambiguous, and continues to develop in different directions on a daily basis. Therefore, in order to understand the fundamental nature of machizu$k u r i$, it is imperative to trace its history. The following discussion first will look briefly at the history of this phenomenon, and will then examine the basic nature of, and crucial problems related to, machizukuri from an urban planning point of view. The examples that will be introduced are among the most progressive ones at the national level; the overwhelming majority of communities and municipalities, however, are still bound by a traditional system that is often removed from the essence of machizukuri.

\section{The birth of machizukuri: 1950s and 1960s}

Although urban planners adopted the term machizukuri around the 1960s, it actually originated in the field of social studies (Watanabe et al. 1997). In 1952, the noted social historian Masuda Shirô, in the context of promoting local autonomy during the postwar democratization process in Japan, portrayed the ideal governance of the future municipality as "new machizukuri," or building the new local community, referring heavily to the urban history of medieval northern Europe (Masuda 1952). Masuda, however, did not precisely describe machizukuri, using the term simply as a slogan. 
Since that time, machizukuri has been used as a catchword in various fields. Because it implies a kind of reform movement at the local level in the postwar democracy, machizukuri can be defined broadly as the process whereby entities engage in activities or movements in a local community. Such a loose concept was convenient in that many ideas and desires could be associated with the word and this became a prototype for the usage of the term thereafter.

A notable early example of the wide application of the term is the Council of Social Welfare (CSW) movement (Shakai Fukushi Kyôgikai) (Nihon Chiiki Fukushi Gakkai 1993). In 1949, the Ministry of Welfare created this association for the purpose of importing methods of community organization from the United States. Local branches of the group were subsequently established in every municipality and prefecture under the aegis of the national headquarters, and these continue to function into the present day. During the 1950s, those involved in the CSW movement often referred to their work as machizukuri. The basic charter of the CSW defines the group as "a private voluntary organization . . . by people in the community involved in social welfare in a broad spectrum of both the public and private sectors, in order to promote welfare in its own local community." It was obviously impossible, however, for an organization established by a national ministry with representatives from the private sector to act as a "private voluntary organization" at this time in Japan, where there was little tradition of citizen input independent of the government. Rather, the CSW functioned as a quasi-governmental body, or private means for providing government welfare services at the local level. While machizukuri in this case indeed could be seen as a citizens' movement at the municipal level, there was a clear lack of autonomous decisionmaking by the citizenry.

In the field of urban planning, there were roughly two attitudes toward machizukuri. One view, held by many planners, equated machizukuri with traditional statutory urban planning, using the term to include the land-readjustment projects of the postwar reconstruction program as well as any road construction. In this view, machizukuri was simply a label, and as such gave rise to no innovative perspective.

Another view was held by a smaller number of planners, who approached urban design at the local district level. The rapid economic growth in the 1960s was accompanied by an increased interest in urban redevelopment and improvement of residential environs, which led to the involvement of local residents in city planning and design (see also Chapter 2 by Ishida Yorifusa in this volume). The best-known example can be found in the Sakae-Higashi district of the city of Nagoya (Hattori 1973). A resident merchant turned activist, who together with volunteer professionals had organized a small informal study group in the late 1950s, eventually proposed a redevelopment plan for the district in 1964. The plan was based on the complete clearance and redevelopment method (razing the area and rebuilding from the ground up) and, following the modern planning paradigm of the day, strove for an urban image that featured super-blocks of high-rise buildings in open green space. This was, in fact, the first instance in the history of urban planning in Japan of a full-scale, well-developed plan proposed 
and created by a citizens' group. The plan was not implemented, however, both because residents resisted completely rebuilding their homes and businesses to accord with a modern lifestyle, and because there was no legal framework for carrying out such a large-scale redevelopment project. But the real problem, in the end, was that there was no substantial organized segment of the local population participating in the plan-making process.

\section{From opposition to partnership in machizukuri: 1960s and 1970s}

As a result of the brisk economic growth that took place in Japan during the 1960s, with people and industry rushing in to concentrate in existing large urban areas, serious problems such as housing shortages, traffic congestion, and environmental pollution arose. These problems threatened the residential life of local citizens in many ways. Some resident groups organized opposition movements to protect their quality of life and property, proudly calling the popular movements machizukuri. For the first time, independent participation by city inhabitants began to emerge.

In 1963-5, for example, the residents of Mishima, a coastal city at the foot of Mount Fuji, successfully contested the government's plan to build an industrial complex on landfill there. Also, in 1967-8, the inhabitants of the Tsujidô district in Fujisawa, a suburban center in the southwestern greater Tokyo area, fought to overturn the city's land-readjustment project for residential development. These incidents revealed another side of traditional urban planning - which heretofore had been perceived as an unmitigated good - that at times it could be used to destroy established residential life. Machizukuri became a rallying cry, representing the antithesis of statutory urban planning.

Although the above two cases were symbolically important as opposition movements, they disintegrated once their goals were attained. However, other movements instigated by local residents that had a variety of goals did materialize and were more long-lasting; these formed the wellspring of the main stream of machizukuri. In 1963, dump trucks rolled into the quiet residential Maruyama district on the city of Kobe's mountainside, for the purpose of constructing a housing development. This triggered an opposition movement by residents of the district under the banner of machizukuri to protect the quality of their pastoral living environment from dense urban development (Hirohara 1974). Capable district leaders took the initiative in organizing residents, instigated and developed innovative programs for community networking and self-education, and persistently engaged in negotiations with city officials. This movement, which grew to include a full-time staff and central secretariat responsible for organizing a large number of residents, became known as the "Fighting Maruyama." In terms of its style and spirit, it resembled a community version of a labor union movement. Although Maruyama started out as a simple opposition movement, its scope expanded to address such issues as traffic problems and the local environment overall. Residents achieved enough political clout to voice demands and to acquire various public services from the municipality of which it was part. City officials, who were for 
the first time forced to produce a counter-offer to the demands, learned valuable skills in negotiating with the residents through this process. As a result, the relationship between the local community and the greater municipality began to shift from opposition to partnership in the second half of the 1960s. Importantly, this partnership was never imposed by the municipality, but instead knitted together by the residents themselves from their evolving experiences.

At about the same time, in the heavily inhabited Mano district, situated along the coastline of the city of Kobe, where industry and housing were heavily mixed, local residents began a machizukuri movement to protect inhabitants, particularly small children, from air pollution caused by the factories in the area. The movement did not develop as immediately and distinctly as the Fighting Maruyama, but gradually enlarged its purview to include the protection of the overall local residential environment. In the late 1970s, in cooperation with the city of Kobe, the group began environmental improvement projects such as building public housing and upgrading pedestrian streets. The movement continues to have positive results even today, in contrast to that in Maruyama, which virtually dissolved toward the end of the 1970s.

According to the traditional paradigm subscribed to by professionals and government officials, urban planning applies specifically to the planning and construction of physical facilities. From this standpoint, neither Maruyama nor Mano had much to do with "urban planning." Some planning researchers, however, began to study the process through which local residents, through their own organized activities, improved both built aspects of their community as well as those relating to quality of life, as in these two districts (Hirohara 1974). The study found that gradual improvement in the physical living environment that accorded with current local needs was a realistic approach, in contrast to submission to a preconceived plan for complete clearance and redevelopment. In terms of how these changes were implemented, it also found present a public-private partnership with intensive participation by residents. The results of the study were reported to the public as well as to the academic community, and the basic principles it uncovered have become the foundation for the majority of machizukuri activities ever since. This "postmodern" approach to urban planning clearly differs from the "modern" one that characterized Sakae-Higashi.

In the 1960s, especially in urbanized areas, elections for the heads of local governments were won by candidates who were supported by the socialist and communist parties, defeating the conservatives. Emphasizing social welfare programs rather than economic development projects, they presided over what were called "progressive local governments," beginning with that of Yokohama's mayor, Asukata Ichio, in 1963, followed in 1967 by Tokyo's governor, Minobe Ryôkichi, and Kobe's mayor, Miyazaki Tatsuo. These leaders made efforts to turn the municipality - historically a subsidiary branch of the national government - into a base for providing public services to the local community. Noteworthy here is the fact that progressive leaders directly elected by the people promoted citizen participation in their policy-making in order to bypass the local assembly, which was still dominated by the conservatives. At the same time, they encour- 


\section{Watanabe}

aged municipal officials to act from the citizen's point of view rather than from that of the traditional bureaucrat. As a result, an increasing number of government officials began to be open to the idea of machizukuri (Tamura 1987).

During the 1960s through the 1970s, the main concern of urban planning shifted from regional-scale infrastructure building to local-scale environmental improvement in existing urban areas. The national Urban Redevelopment Program, which began in 1969, introduced into the field of planning the new issue of how to resolve the myriad interests of the large number of people involved. District planning legislation, passed in 1980, called for the essential participation of residents, particularly landowners, in creating the details of a District Plan and in implementing it at the neighborhood level (see Chapter 2).

In the 1970s, several examples occurred of a municipality actively initiating machizukuri. A pioneer in this regard, the city of Toyonaka, just north of and adjacent to Osaka, launched a unique experiment to improve the residential environment in the Shônai district, where a concentration of wood-framed apartment buildings and houses had emerged during the economic boom. After conducting a detailed study, the city created machizukuri plans to improve the residential environment that incorporated large-scale participation by residents, and began to implement a rehabilitation project. In this project, the idea of complete clearance and redevelopment, as seen in the example of Sakae-Higashi, was rejected and the much more achievable goal of rehabilitation was adopted. This approach later influenced the national housing policy, which had emphasized the building of individual residential units in order to combat the acute housing shortage. The Shônai case, on the contrary, began to draw attention to the gradual improvement of the residential environment as a whole. In 1978, the Residential Environment Improvement Program (jûkankyô seibi jigyô) was added to the national agenda. In the field of architecture, this area of environmental improvement often came to be referred to, narrowly, as machizukuri.

It is clear from the above discussion that machizukuri movements in SakaeHigashi, Maruyama, Mano, and Shônai all raised unique issues and viewpoints in urban planning that previously had barely existed. It is interesting to note that these cases seem to underscore a general tendency in which municipalities in the Kansai region centered around Osaka are more realistic and innovative in approach than those in the Kanto region centered around Tokyo. It is also striking that their ideas were all carried out independently at the local level without the backing of national legislation, and that they influenced the direction of statutory urban planning in the succeeding generation.

\section{The emergence of participatory machizukuri: 1980s and 1990s}

In the 1980s, various statutory measures began to be developed in order to promote machizukuri activities at the national and municipal levels. As noted above, national law established district planning. In forward-thinking municipalities throughout Japan, ordinances related to machizukuri activities were enacted; 
and independent citizen groups were engaged in various activities to promote municipality-wide participation.

In 1981, Kobe was the first city to pass a machizukuri ordinance (jôrei) in Japan and developed an innovative system incorporating three important planning tools that would facilitate participatory machizukuri. The first tool was the machizukuri council (kyôgikai), which represented local residents at the neighborhood level. The second was a system that made professional services, paid for by the city, available to the machizukuri council for machizukuri activities, especially for plan-making activities. The third tool was a procedural structure through which the city would officially accept a machizukuri proposal (teian) from any machizukuri council and would develop a machizukuri agreement (kyôtei) with it that would be eventually implemented. This sort of intensive participatory provision did not exist in the national system of statutory urban planning at that time - nor does it today. It proved to be an extremely effective system in the reconstruction process later on, after the Kobe Earthquake of 1995, as the challenge of the huge amount of reconstruction planning was fairly successfully met by efficient collaboration between the city and local residents who had been familiar with participatory machizukuri.

Following Kobe, the Setagaya ward in Tokyo was the next to establish a machizukuri ordinance, in 1982. After 1990, many innovative municipalities created their own machizukuri ordinances to supplement the national City Planning Law of 1968 (shin toshi keikaku hô) and conducted various trials to support machizukuri activities on a broader scale than the nation's statutory urban planning allowed (Kobayashi 1999).

Also, beginning with the Nara Machizukuri Center, which opened in 1984, similar "machizukuri centers" were established in many localities throughout Japan in order to provide citizens with professional support for machizukuri activities. Many of them evolved into nonprofit organizations (NPOs) after the Nonprofit Organizations Law (NPO hô) was passed in 1998. Hence, by this time all the major machizukuri organizations - those of municipalities, citizen groups composed of residents, and NPOs - were in place.

The main characteristic of machizukuri during the 1990s was that citizens began to participate in plan-making, spurred by the 1992 amendment to the City Planning Law, which called for mandatory citizen participation in the creation of a municipal master plan. In an effort to incorporate new approaches to creating a master plan, many municipalities began to experiment with new methods, such as workshops for citizens with little knowledge or experience in urban planning (Watanabe 1999). The 1992 amendment thus marked the beginning of genuine citizen participation and master planning in Japan (see also Chapter 2).

In this context there arose one remarkable type of citizen activity, a phenomenon whereby citizen groups, unsatisfied with the participation opportunities offered by the municipality, created their own "master plan" and offered it to the municipality and to the public. This kind of plan was called the "citizen-made" (shimin-ban) master plan. The first example occurred in 1994 with a plan report titled "Community where Residents Play in Harmony" (Sumu hito no kyômei suru 


\section{Watanabe}

machi) that was created by a citizen group from Komae, a suburban municipality just south of Tokyo's Setagaya ward (Komae no Machi wo Kangaeru Kai 1994). Seven such master plans were made in the following three and a half years. In most cases, these reports were prepared by citizen groups of 20 to 40 members who worked for about two years. Ranging from 14 to 150 pages in length, these reports used far fewer sophisticated technical terms and incorporated livelier charts and illustrations than the documents created by municipal officials, thus being much easier to read and understand for the average citizen (Watanabe 1998, 1999). However, although these reports were published, they had little impact on the plan-making process of the municipalities.

\section{The basic principles of participatory machizukuri}

The global history of urban planning shows that progress in planning in terms of vision and skills was made often through citizen-initiated proposals. Important examples include the garden city concept (1898), propounded by Ebenezer Howard, a British reformer, and the Chicago Plan (1909) by the American architect Daniel H. Burnham, which was supported by a Chicago citizens' group. However, as urban planning later became part of government services that were administered by professionals, it became disconnected from the ideas and wishes of citizens and amateurs. In Japan as well as the United States, criticism of and rebellion against this tendency began in the 1960s. Notably, while such opposition was targeted primarily at bureaucrats in Japan, in the United States it was directed toward professional planners.

In the Japanese example, the citizen-made plan seems to be an important key to the continuing development of participatory machizukuri and even statutory urban planning in the early twenty-first century. In order to discuss what this phenomenon implies, it is important to first examine what is meant by "participation."

Often misunderstood, "participation" in machizukuri does not mean simply involvement in the "process" of public policy-making - attending group meetings and workshops, answering questionnaires, speaking out at a place set up by the municipality. The essence of participatory machizukuri is and should be effecting the "product" - the involvement of citizens at the municipal government level and the resulting reflection of their opinions in the making of public policies.

Generally speaking, municipal policies are first set by the legislature in various forms, which include ordinances, plans, and programs, and are then carried out by the administration. These policies go through three stages - proposal, officialization, and implementation - before affecting the lives of citizens. Within this framework, citizen-made plans can be defined as participation in plan-making at the proposal stage. This suggests the possibilities for participation in other forms and at other stages. Citizens should have a chance to participate in ordinances and programs at each stage. At the stage of plan implementation, citizens should have the right to participate in the carrying out of the plan by the municipality or on their own directly, and by monitoring the process.

In the context of local autonomy and individual responsibility, citizen propos- 
als in the form of ordinances, plans, and programs should be widely welcomed although it remains the decision of the municipality whether these proposals are adopted or rejected. Ideally, citizens should be able to come up with ideas, expand them, and make them into well thought-out proposals, as well as have the ability to read, understand, and evaluate proposals made by others, including the municipal administration. Thus, participation in municipal governance needs citizens with a high level of skills.

\section{Crucial problems for participatory machizukuri}

This kind of all-inclusive participation in municipal governance is yet to be seen in Japan, but a growing number of citizens demonstrate a desire to become actively involved through machizukuri activities. However, two crucial problems first need to be addressed.

The first problem is the lack of a legal system that provides procedures to guarantee a citizen's right to participate. The decision-making power at the municipality level has been traditionally held by the administration rather than by the legislature; the former has also had a strong tendency to deny citizen participation in the government. Recent demand by citizens for participation has increased to such a degree that many municipalities do attempt to respond to it. In many cases, however, the participation provided for is superficial, and does not extend beyond what Sherry R. Arnstein calls "tokenism" (Arnstein 1969). In fact, except for a few innovative municipalities, there is no established system that allows true citizen participation. There is rarely a procedure, for example - as in Kobe - whereby residents can propose a plan at the neighborhood level and the municipality, after careful consideration, rules officially whether or not to include it as part of its master plan for the city as a whole. In short, there are in practice few rights and obligations in regard to participation that are clearly guaranteed by national law or by local ordinance.

The second problem is a lack of skills on the part of the citizens for participating in municipal governance. Most citizens are laypeople in the field of urban planning, and so it is often difficult for them to even read and understand policy proposals, let alone to make plans without outside help. Certain technical support is essential, and an important question is who should provide such support - the municipality itself or consultants paid for by the municipality, or perhaps consultants chosen by the citizens. All these issues are yet to be resolved.

In order to overcome these two problems, it is necessary to establish some concrete measures and a basic guiding principle that will facilitate citizen participation. An effective basic principle might be summarized as follows: Any citizens' group has the right to initiate, create, and publicize a policy proposal and the right to receive necessary technical support in order to make such a proposal. Given that such a principle is not yet established in Japan, a concrete step would be to codify the following rights and obligations.

The first principle to establish is the citizen's right to make a policy proposal. Under this principle, anyone has the right to suggest a policy proposal to the 


\section{Watanabe}

municipality regarding any issue at any time in the form of an ordinance, plan, or program. In the case of a plan, citizens can make a proposal regardless of its scale of application whether at the city, community or neighborhood level and regardless of its area of services. The specification of "any time" establishes a principle that would guarantee a citizen's right to submit proposals without taking into account the municipality's schedule for reviewing, creating, and revising plans, which occurs only once every several years. By stating "anyone," this principle applies not only to residents who own property or live and work in the area but also those who have a special interest in it. This principle should not be limited to individuals but should be applied also to corporate bodies. Upon receiving a policy proposal, the municipality should have the obligation to carefully examine it and to decide either to accept or reject it. In case of rejection, the municipality should be obligated to specify its reason.

Establishing this system alone, however, is insufficient. How the citizens can utilize the system and make it bear the fruit of participation is also important. This will require citizens to have certain skills to engage in discussions on a par with bureaucrats and local assembly members. To do so, it is most important that citizens possess independent initiative, the ability to generate ideas, and overall technical and social skills. To strengthen these skills, citizens must study and grow. In this sense, community-building is human resource building. If an independent-minded citizen wishes to obtain the above skills but does not know how, the municipality would be well-advised to help that individual, as this would be in the public interest in the long run.

The second necessary principle is the municipality's obligation to provide support. Under this principle the municipality must provide assistance to those citizens, upon their request, who want to start machizukuri activities but who do not have the necessary skills. In the case of citizens who are working toward a policy proposal, the municipality should help citizens to formulate a proposal that is satisfactory for public debate. This assistance can take the form of helping with logistics (for example, offering office space), providing technical information, giving financial assistance, and/or sharing professional expertise. The machizukuri ordinance passed in 1992 by the city of Toyonaka facilitated a citizens' group in the process of setting up a "machizukuri study group," guaranteeing it financial support until it can develop into a "machizukuri council."

Of course, whether this support system is fundamentally the function of the municipality is highly questionable. Ideally it should be the function of a nonprofit organization. In many places today, "machizukuri centers" established as NPOs to support machizukuri activities are being created by the private sector alone or jointly by the private and public sectors. It seems more desirable for the support system to be a municipal function, but one in which the municipality serves as a background facilitator to encourage citizens to act freely from the bottom up, rather than control their activities from the top down.

Clearly, it is necessary to establish the right of citizens to make proposals and the obligation of the municipality to provide support. For this to occur, the machizukuri ordinance - which comprehensively spells out the framework for 
supporting citizen participation in the municipality - is essential. An innovative example can be seen in the machizukuri ordinance of the city of Minoo (1997), which points toward this direction.

\section{Machizukuri and the future}

It can be assumed that in twenty-first-century Japan urban planning powers will be put entirely into the hands of the municipality, which will make all planning decisions regarding matters within its purview. The master plan will be the center of the municipality's planning policy. Whenever necessary, the municipality will create not only a master plan for the entire territory but also such plans for specific functions or areas. They will be proposed first as policy alternatives and subsequently enacted into regulation by the local assembly, becoming official policies to be eventually implemented. Consequently, the master plan will be amended continually in a flexible and dynamic way. It will be significantly different from the rigid and static concept of traditional statutory planning.

The process of creating and revising a master plan requires the establishment of a principle of disclosure and open participation whereby committee meetings are open to the public and the committee members are selected from among the public. In order to ensure transparency in the policy decision-making process, all information should be made available, and decisions should be reached, not behind closed doors, but through an open discussion with public input. Only then should the final official decision be made by the assembly members or mayor, who are strictly accountable to the public by the fact that they are elected.

The participation opportunities should be widened to include not just the stage of preparing a plan but even the evaluation of its implementation. Citizens should have the right to observe and evaluate the implementation of the plan that was prepared by virtue of their participation. They should also have the right to propose, if necessary, any amendments or an entire remaking of a plan at any time.

By such constant feedback, municipal officials, assembly members, professionals, and citizens will improve their planning skills and will gain increased confidence in participation as well. This process will also alter the style of various kinds of official planning. Being more vulnerable to strict evaluation at the implementation stage, plans created in the future will become clearer expressions of municipal policies, responding more sensitively to local political issues concerning the residents. Plans will become more concrete, realistic, and readily comprehensible, in contrast to the present style, which can be characterized as abstract and unrealistic, and often conceals core issues from the local inhabitants.

The principles discussed above should apply not only to the master plan but also to other official plans, such as a municipality's Comprehensive Plan and the Housing Master Plan. The impetus for such change lies with the citizens, who possess ever more sophisticated skills and who are growing in number in each area of various machizukuri activities. In this way, traditional statutory urban planning will be challenged by the machizukuri initiatives advanced by citizens and will undoubtedly be forced out of its stranglehold. Participatory machizukuri, 


\section{Watanabe}

therefore, will be responsible for no less than changing the face of urban planning in the twenty-first century.

\section{References}

Arnstein, Sherry R. (1969) "A Ladder of Citizen Participation," Journal of the American Planning Association 35(4): 216-24.

Hattori Chiyuki (1973) "Toshi saikaihatsu ni kansuru kenkyû: Nagoya-shi Sakae-Higashi chiku toshi saikaihatsu" (Study of urban redevelopment: a case study of the urban redevelopment project of the Sakae-Higashi district in Nagoya city), unpublished $\mathrm{PhD}$ dissertation, University of Kyoto.

Hirohara Moriaki (1974) "Kyojû kankyô keikaku ni okeru kyojûsha yôkyû no hatten katei ni kansuru kenkyû: jûmin shutai no machizukuri undôron josetsu" (Study of the development process of inhabitants' demands in residential environment planning: introduction to the resident-initiated machizukuri movement), unpublished $\mathrm{PhD}$ dissertation, University of Kyoto.

Kobayashi Shigetaka (ed.) (1999) Chihô bunken jidai no machizukuri jôrei (Machizukuri ordinances in the era of decentralization), Kyoto: Gakugei Shuppansha.

Komae no Machi wo Kangaeru Kai (1994) Sumu hito no kyômei suru machi (Community where residents play in harmony), privately printed.

Masuda Shirô (1952) "Toshi jichi no hitotsu no mondaiten" (A crucial issue in urban autonomy), Toshi Mondai 43(2): 49-59.

Nihon Chiiki Fukushi Gakkai Chiiki Fukushi shi Kenkyûkai (Association for local welfare in Japan. Study group for the history of local welfare) (1993) "Dai toshi ni okeru chiiki fukushi no tenkai ni kansuru rekishiteki kenkyû" (Historical study of the development of local welfare in large cities), in Nihon Chiiki Fukushi Gakkai Chiiki Fukushi shi Kenkyûkai (Association for local welfare in Japan. Study group for the history of local welfare) (ed.) Chiiki Fukushishi Josetsu: Chiiki Fukushi no Tenkai to Keisei (Introduction to the history of local welfare: the development and formation of local welfare), Tokyo: Chûô Hôki Shuppan, pp. 96-165.

Tamura Akira (1987) Machizukuri no hassô (The concept of machizukuri), Tokyo: Iwanami Shoten.

Watanabe Shun-ichi J. (1998) "Citizen-Made Master Plans as a Tool for Participatory Planning," paper presented at the International Symposium on City Planning 1998, Kangnung, Korea.

_ (ed.) (1999) Shimin sanka no machizukuri: master-plan zukuri zukuri no genba kara (Machizukuri by citizen participation: reports from the field of master-plan making), Kyoto: Gakugei Shuppansha.

Watanabe Shun-ichi J., Sugisaki Kazuhisa, Ito Wakana, and Koizumi Hideki (1997) "Yôgo 'machizukuri' ni kansuru bunkenteki kenkyû 1945-1959" (Bibliographical survey on the word "machizukuri" 1945-1959), Papers on City Planning 32: 43-8. 


\section{Whose Kyoto? \\ Competing models of local autonomy and the townscape in the old imperial capital}

\section{Christoph Brumann}

While it may appear obvious to regard Kyoto, Japan's imperial capital from 794 to 1868 , as the quintessential old city (koto) of the nation, not everything in the city is as old as it seems. Nara, Kyoto's predecessor as the emperor's seat, has a longer history and arguably has changed less in recent years. Its buildings are definitively older than those in central Kyoto, where very little remains from that city's first four centuries when it was known as Heian-kyô, the shining capital, and witnessed the first great flourishing of an indigenous high culture. Subsequently, there have in fact been many Kyotos, reborn like phoenixes from what were literally the ashes of the previous city, destroyed in fire or battle. The image of the "old city," therefore, is comparatively new, coming into full bloom only after World War II, which spared Kyoto almost entirely. Today, Kyoto appears indeed more ancient than the other, rebuilt Japanese metropolises and can live on its history to a considerable extent. Alongside the ongoing traditions of Buddhist monastic centers, tea-ceremony schools, handicraft workshops, and geisha quarters, the unmatched collection of historical temples and shrines, palaces, and gardens is the most impressive component of Kyoto's cultural heritage. Almost 40 million tourists visit these sites every year, often paying significant entrance fees to do so. Yet it is not only these icons of high culture that survive but also traditional wooden buildings intended for everyday use. After the war, all of Kyoto consisted almost exclusively of traditional architecture and it was very likely the largest wooden settlement in the world. What remains of the historical townscape today contributes toward imparting to visitors the feeling of having entered the "heartland of Japan" (Nihon no kokoro no furusato). With everything else changing so quickly in postwar Japan, Kyoto's role for a nation on the move has been to stand still, as much as possible.

Change, however, could not be kept at bay forever: since the 1970s primarily, the built environment in Kyoto has been greatly transformed. Particularly during the "bubble period" of the years leading up to 1991, rampant real-estate speculation and skyrocketing land prices hastened the demolition of ever larger numbers of traditional wooden town houses (machiya) and their replacement with high-rise condominiums (manshon), office buildings, prefabricated single-family houses (purehabu), and parking lots. The new structures introduced a hodgepodge of almost always non-local styles, and often also overshadowed adjacent houses and 
blocked the view of the surrounding mountains, a celebrated feature of Kyoto's townscape. Widespread dissatisfaction with this state of affairs has repeatedly led to heated controversies, most intensely around 1990 when, in defiance of former limitations, both the new railway station complex and the rebuilt Kyoto Hotel were permitted heights of 60 meters. The economic crisis following the burst of the "bubble" reduced the demand for monumental buildings and therefore also the occasions for further grand-scale "landscape disputes" (keikan ronsô), as such conflicts have come to be known (Iida and Nanbu 1992; Noda 1998; Peternolli 1996; Takamichi 1993; Ueda 1991; Watanabe 1994). In addition, the remaining machiya have become the object of a strong revitalization movement: many hundreds of these structures have been remodeled into restaurants, cafés, shops, or fashionable residences, and modern buildings also incorporate elements of machiya style (Brumann 2001a). To a lesser extent, prewar western-style architecture is being reappraised as well.

After a lull in the immediate post-bubble years, however, manshon construction in central Kyoto attained record levels in the late 1990s and early 2000s, greatly encouraged by a sharp decrease in land prices and construction costs and by relaxed building regulations. Among the buyers of the apartments in these highrises is a growing number of older inner-city returnees, for whom - in a somewhat perverse feedback loop - revitalized machiya and the remaining scenic streets form part of the lure of urban life. Almost every manshon project is disapproved of by its neighbors, however, and many encounter organized resistance so that, if anything, keikan ronsô are today an even greater part of the Kyotoites' urban experience than during the bubble years. Many citizens agree that the townscape is in crisis, and some see it as irremediably damaged. As a consequence, the future of Kyoto's built environment is now a widely acknowledged concern, as attested to by the multitude of related proposals, projects, publications, groups, institutions, and organized activities, with hardly a week going by without a related meeting, symposium, public lecture, or other event.

More than is immediately apparent, the problems affecting central Kyoto's townscape are influenced by aspects of local autonomy and self-rule, and the question of whose Kyoto it is after all - that is, who exactly has a right to make decisions affecting the city - is crucial for the way they unfold. The following is a social-anthropological analysis of these connections, building on my own ethnographic fieldwork conducted in Kyoto over 17 months in 1998-9 and two months in 2001. ${ }^{1}$ Three models of local autonomy can be distinguished, represented in turn by the traditional neighborhood associations, the numerous citizen groups, and the municipal administration's new dialogic approach. I will attempt to demonstrate their respective strengths and weaknesses and to show how they all find their limits in another, ultra-local kind of autonomy, that of the individual real-estate proprietor.

\section{Neighborhood associations}

It is often said that Kyoto has no tradition of self-rule. Rather, with their everchanging overlords, the citizens learned to fare best by keeping a low profile. This 
historical lesson supposedly has sedimented into a collective mentality, prompting Kyoto's inhabitants to passively accept whatever is imposed on them (although they are prone to retaliate by merciless backbiting). Indeed, the townspeople have been under the authority of feudal lords and shogunate (bakufu) officials for most of the city's history. Yet contrary to stereotype and in spite of the city's saturation with nobility, warriors, clergy, and, above all, the imperial court, the ordinary merchants and craftsmen of Kyoto wielded a significant amount of power at times and were left to regulate their own internal affairs almost continuously.

Neighborhood associations in Kyoto have a particularly long history. Throughout the modern era, the basic unit of organization has been the so-called ryôgawa-chô ("two-sided block"): in Kyoto's characteristic rectangular grid of streets, a typical block (chô) includes the houses on both sides of a street from one corner to the next. The origins of cho organization are believed to lie in the late fourteenth or early fifteenth century (Ôzuka 1994: 39; Wakita 1999: 174-5). In 1419, legal documents mention chônin ("people of the chô"), apparently as the representatives of particular neighborhoods, testifying and making pledges for them (Wakita 1999: 182-4). The earliest recorded name of a chô is from 1455, and by the first three decades of the sixteenth century such names had become common (Berry 1994: 212). Many of these names persist today also as part of official mailing addresses. Noblemen's diaries from the first half of the sixteenth century include entries for defensive or punitive action by large numbers of chônin, and the chô begin to be addressed as corporate entities in government bulletins and legal documents. The latter were often provoked by resistance to tax payments or corvée labor, which in itself attests to a growing self-confidence on the part of the chô. In addition, the chô and their representatives came to be relied on by military rulers for tax collection, internal policing, and the mediation of disputes, being granted tax exemptions in return (Berry 1994: 214-15, 218-20, 225-9, 235-6).

Mary Elizabeth Berry argues that, between the start of the Ônin war (1467-77) and Oda Nobunaga's taking of Kyoto in 1568, this pattern of urban organization arose when - or even because - the alternatives failed: feudal attachments lost their importance for urbanites who began to rent, buy, and sell land rather than receive it for vassalage; guilds and commercial associations no longer managed to control an increasingly unfettered market; and the possibility of religious organization based on the temples of the Nichiren sect was shattered by the brutal suppression of the Hokke uprising in 1536 (Berry 1994: 210-41). What remained was organization based on spatial proximity, since "a politics of place is ... a politics that arises from divided interest and contention" (Berry 1994: 232). There is, however, an important positive incentive too: as demonstrated by emakimono picture scrolls of the period, commoner houses had begun to stand in rows without intervening spaces already by the twelfth century (Löfgren 2003: 68-70). This, although advantageous in other respects, encouraged the almost instantaneous spread of fires. Organizing with one's neighbors, rather than with people living elsewhere, therefore, offered the chance to control the very people whose potential carelessness might affect one's livelihood most catastrophically. The forced unification and pacification of Japan by the successive military dictators Oda Nobunaga, Toyotomi Hideyoshi, and Tokugawa Ieyasu ended the short 


\section{Brumann}

spring of citizen self-assertion. It deprived urbanites of the military potential they had tapped in the Hokke uprising (Berry 1994: 143-53) and relegated craftsmen and merchants to the bottom rungs of the new status order. As in other cities, however, the chô of Kyoto remained little republics unto themselves throughout the Tokugawa period: they had gates (kido) that were closed at night, settled their own disputes, acted as legal entities with the power to enter into contracts, borrow money, or file lawsuits, and paid government taxes collectively while charging their own, separate fees (Itô 1994: 171; Wakita 1999: 185). The chô also selected residents by consensus, often demanding an initial investment that could amount to no less than one-tenth of the price of the plot of land and house acquired. Invariably, the chô had an assembly house (chôkaisho, chôie, or chôseki) and employed a guard (bannin) who was responsible for closing the gates and patrolling the neighborhood.

Kyoto's chô also established detailed written rules, the so-called chôshikimoku or chôsadame, which had a direct bearing on the townscape. A good part of these rules consisted of instructions for building, fire precautions, and firefighting, and stipulated, for example, whether or not a warehouse (kura or dozô) could be located on the streetfront, or, in the event of a fire, how many houses next to a burning house could be torn down to prevent the spread of flames, with the proviso that they be rebuilt jointly afterward (Itô 1993: 311, 314). The fact that Kyoto's urban landscape became much more uniform after the mid-seventeenth century, moving away from the earlier individualistic, even extravagant buildings (Salastie 1999: 52), must certainly be attributed in part to these self-imposed building codes in addition to the shogunate's sumptuary laws. Citizen self-rule worked so well that firefighting remained neighborhood-based in Kyoto, in marked contrast to the socially more volatile Edo (present-day Tokyo) where anything short of professional firefighting brigades failed (Brumann 2001b; Ikegami 1988; Kelly 1994: $315,320,321-22,330)$.

The chô of Kyoto banded together in larger, discrete chôgumi (groups of chô), first mentioned in 1537 (Itô 1994: 161-2), and these were again united into the two units of Kamigyô (the "upper city") and Shimogyô (the "lower city"). Both of these levels apparently were less important than the chô, as they had no written rules, and Kamigyô and Shimogyô were mainly convenient points of liaison from which to forward communications from shogunal authorities (Itô 1994: 165, 170). Nonetheless, the chogumi provided the framework for the rapid expansion of Kyoto in the seventeenth century: newly settled chô territories were incorporated into the existing units, resulting in a pattern in which the initially separate core territories of Kamigyô and Shimogyô - the first parts of Kyoto to be resurrected after the Ônin war - were increasingly surrounded and connected by outlying "colonies" (Itô 1994: 168). This pattern of local organization did not challenge military rule and the general status order of Tokugawa society. Nor did it bring about internal democracy, as status differences persisted both between the older and newer chô in the same chôgumi (Itô 1994: 172) and within the chô, with property owners ranking above tenants, and streetfront residents above back-lane dwellers. Nevertheless, commoners were used to managing their own affairs, and 
as long as they did so quietly, this served both their interests and the shogunate's idea of social order.

After the Meiji Restoration of 1868 and the abolition of fixed social status, the prefectural government rationalized the chôgumi territories, creating roughly rectangular shapes and similar sizes. Known as bangumi, these units collectively managed to raise the funds for opening Japan's first elementary schools only a year later, thus accomplishing one of the most celebrated feats of the machish $\hat{u}$ ("townsfolk"), or Kyoto commoners. The new buildings were not only used for education but they also served as a police station (kôban), fire watchtower, health insurance bureau, population registry, stamp vendor, and assembly hall. With the end of World War II, all remaining administrative tasks were taken over by municipal government offices (Yoneyama 1986: 13-14) whose lowest level of subdivision are the 11 wards $(k u)$ that each contain hundreds of chô. In addition, neighborhood associations - further discussed by André Sorensen in Chapter 5 - were banned by the Allied occupation, given that they had been used as instruments for totalitarian control during wartime; to this day, the revived associations' legal status remains weak at best.

With the closure of most schools in the 1990s (the dwindling numbers of students were concentrated in the remaining schools), the bangumi territories lost their last official rationale. Nonetheless, the jichi rengôkai, as the neighborhood associations are now called, continue to base their territories on the old school districts. It is on the jichi rengôkai level that most neighborhood activities, such as undôkai (athletic field days), day trips, activities for children and the elderly, the training of voluntary fire brigades, hi no yôjin (fire awareness) patrols, and town revitalization workshops, occur today. Jichi rengôkai leaders also expect to be taken as the mouthpiece of local sentiment by the municipal administration, which also supports their work with moderate subsidies. On a subordinate level, the chô or (o-)chônai (as they are most commonly called in everyday speech) assume responsibility for such tasks as distributing information brochures and posters issued by the municipality. They also retain their own recreational activities, such as the Jizôbon summer festival, and participate in larger shrine festivals such as the Gion matsuri. Neighborhood self-organization in Kyoto's center is clearly livelier than in other Japanese cities. A smaller, aging population is a common concern, however, and the jichi rengôkai in particular are also often seen as conservative institutions, dominated by elderly men and often ruled singlehandedly by one strong and outspoken personality. Although membership in the chônai is open to any household within their boundaries, those in single-family houses are much more likely to join - or have already done so generations ago - whereas the residents of multifamily apartment houses are often not interested in joining or have not been asked to join in the first place.

In 1999, I had the opportunity to observe a particularly impressive instance of neighborhood cooperation in Miyabiyama-chô, ${ }^{2}$ a chônai of about 20 households distributed over not quite 120 meters (Figure 7.1). Since 1500, this centrally located neighborhood has contributed a yama (float) to the Gion matsuri, the most famous traditional festival in the city and arguably also in the nation (Tani and 




Figure 7.1 Territories of chô (indicated by dotted lines) and jichi rengôkai (indicated by solid lines). MY-C, Miyabiyama-chô.

Masui 1994; Wakita 1999; Yoneyama 1974, 1986; Yoshii 1994). During the week leading up to the July 17 Yamaboko junkô parade, consisting of 32 floats accompanied by the chônai men dressed in samurai clothing, every household works feverishly on the construction and decoration of the yama and a large number of other preparations. While funding comes primarily from state, prefectural, and municipal subsidies, the workload and the expenses for the traditional garments or the entertainment of the many guests, for example, are borne by the residents. A remarkable amount of coordination and cooperation is required but, despite the manifold tasks and the burden of responsibility, a joyous atmosphere prevails, with participants emphasizing the ways in which contributing to this event bolsters neighborhood solidarity to a level unknown in those chônai that do not have a float.

The general management of festival participation falls to the Miyabiyama Foundation, of which, as in the chônaikai, each household is a member. Other than the post of chônai head (chônai kaichô), which rotates annually, foundation 
offices are attained only through long years of committed service, and tenures are also long. The foundation is said to have democratized considerably under the current chairman, a retired company director who has made a point of consulting the other office-holders over important issues. This contrasts with his predecessors, who used to decide everything by themselves, down to their deputies who would customarily follow them in office. Deference to age and experience is still evident, but discussions have become quite open, with younger people unafraid to speak their minds. Clearly, the neighborhood has come a long way from prewar conditions - under which festival participation was financed by a few wealthy landowner households, with all other residents, particularly tenants, following their dictates, and with status differences continuously on display.

The self-imposed building codes of the chôshikimoku are long gone, but the social closeness created by the festival has worked to preserve Miyabiyama-chô's townscape on at least one occasion: in the 1980s, one resident planned to tear down his small house and build a five-floor manshon with studio rental apartments, thus raising the problem of introducing a transient population that most likely would have little intent of contributing to neighborhood life. His Miyabiyama neighbors objected, however, and in the end the resident built a smaller structure with rental offices rather than apartments. Presumably, this also discouraged whatever plans other residents had for high-rise development and, indeed, the chonai was one of the last three among the 32 Yamaboko junkô neighborhoods that still had no highrises. In 2001, however, peer pressure was powerless against a further manshon incursion: the only remaining wholesale kimono-trading company went bankrupt, and its building and plot of land were auctioned off to a condominium developer. A 12-story manshon was completed and the apartments in it sold by the end of 2003.

Because the structure of the condominium conforms to current zoning regulations, residents decided early on that it was futile to put up a fight. Rather, they pressed for compensations by the developer, whose business would be harmed by open protest activities. The chônai residents' demands did not concentrate on the townscape aspect; a height reduction by one floor and some influence on the facade design was all that was achieved in this regard. Rather, the residents pushed to obtain facilities that would benefit neighborhood life. As a result, the new manshon contains a storeroom for festival accessories, chônai assemblies can be held in the manshon's meeting room, and the entrance area will be used for the display of chonai valuables and festival accessories during the Gion matsuri period. In addition, a hokora (small shrine) built on the manshon premises houses the neighborhood's statue of the bodhisattva Jizô worshiped in the popular jizôbon summer festival, which previously had no adequate home. All of this will be provided at nominal charges, and the neighbors feel that, in return for their compliance, they have gained maximum concessions even though greatly modifying the building or entirely preventing it was impossible. They also have invited the manshon residents to participate in the Gion matsuri, hoping thus to secure its future. It is generally agreed that this relatively successful deal owes considerably to the solidarity achieved through cooperation on the festival, as well as to the 


\section{Brumann}

fact that the Miyabiyama Foundation officeholders were proven leaders, making it easier to find chief negotiators acceptable to all.

\section{Citizen groups}

In addition to neighborhood associations, Kyoto is also recognized for its large and lively array of citizen groups (shimin dantai or shimin undô), as befits a major academic and intellectual center and the most important stronghold of the Japan Communist Party (JCP), whose candidates have served as mayor and prefectural governor in the past (Krauss 1980; see also Chapter 6 by Watanabe Shun-ichi in this volume). A large number of these groups - probably more than 100 - focus on townscape issues. Some work for the preservation of historical buildings, others concentrate on revitalizing particular parts of the city, and still others coordinate anti-manshon activities or attempt to address Kyoto's enormous traffic problems, the protection of the surrounding hillside (Hoffman 1996: 558-673), or other environmental concerns. More than the neighborhood associations, which tend to keep to themselves, these groups engage the municipal administration and the various experts that sit on the numerous discussion panels that debate the future of Kyoto. The more politically minded among these groups compensate for unsatisfactory party politics in the city council as well as on the prefectural level, where for more than 20 years a conservative and big-business-friendly coalition led by the Liberal Democratic Party (LDP) has had the communists as the sole opposition, leaving little choice for the considerable number of citizens who feel alienated by both parties. The citizen groups appeal to grassroots democratic principles and often take European and American achievements in political culture, citizen participation, and environmental protection as a model for their own society, whose democratic potential they see as far from exhausted.

One such group is the Mokuzôkai (Wooden Building Association), which for some 10 years has dedicated itself to the preservation and revival of Kyoto's machiya. Membership stands at about 100 and, along with machiya owners and residents, encompasses architects, craftsmen, researchers, and other interested individuals; probably a majority of members have some professional stake in these houses. The main activity is a monthly meeting dedicated to visiting machiya or machiya renovations, hearing lectures on all aspects of preservation, and holding panel discussions, which are sometimes also open to the general public. A newsletter - formerly annual and now bimonthly - is sent to all members. Member architects have been associated with several widely publicized machiya renovations. In 1999, a separate builders' association formed with the purpose of reestablishing the broken bonds between machiya residents and machiya builders. This branch admits only architects, carpenters, and other craftspeople, of whom there were about 30 in 2001. By that time, these members had consulted on almost 200 houses and renovated close to 30; importantly, they had also published a renovation manual. Simultaneous with the builders' branch, the Mokuzôkai also founded a "friends' society" for the approximately 150 laypeople - often machiya residents themselves - seeking a less specialized connection to the houses than 


citizen groups both worked to bring down the plan. In particular, the restaurants and chaya ("tea houses", the location of geisha parties) on Pontochô, a famous geisha quarter (Dalby 1983), feared that the intimacy of this narrow lane would suffer from the proposed approach to the bridge that was to cut right through it. Neighborhood resistance, however, easily succumbed to city government pressure put on the leaders of the chaya associations and other business groups, given that they had a vital interest in ensuring smooth relations with the police and the political and business leaders who were the most likely chaya customers. Although jichi rengôkai office-holders were incensed when municipal officials called a meeting to explain the construction plan, presenting it as a fait accompli, most of them - including the chairman - felt that continued resistance against the municipal government could damage their interests. Not only did they oblige, they also turned against the two office-holders who did not want to give in.

When the locals gave up their fight at the end of 1997, the citizen groups that had formed to oppose the bridge plan stepped in. Since these groups lacked a circumscribed territorial base and were also rather diverse in their social composition - including primarily those with flexible schedules, such as people working in the professions, priests, scholars, retirees, or recent victims of risutora (company downsizing), rather than salaried employees - they could not be suppressed easily. Differing attitudes toward cooperation with the JCP, which was considered a ready supporter of citizen groups but also interested in using the groups for its own agenda, led to the formation of two separate coalitions. One of these became allied with the JCP and concentrated on swaying the city council, while the other chose to maintain its distance from the party, creating a membership association that grew to approximately 250 and used the extraparliamentary strategy of organizing a referendum on the bridge issue. Greatly aided by the media, as well as by many of the mayor's usual allies who also voiced concern over a plan they did not like, these groups brought about the impossible: in August 1998, the mayor withdrew what was an already fully approved and budgeted public-works project (kôkyô jigyô). The end of the Pont des Arts replica project made nationwide headlines (Kimura 1999). To the JCP-related coalition's great dismay, the nonaligned wing received most of the media credit; certainly, its prominence had made it easier for the mayor to give in than if only JCP-affiliated groups had been active.

The groups opposed to the Pont des Arts formed around veterans from previous disputes who as a result had both experience and useful contacts. Although in the past citizen groups have been rather successful in fighting a number of controversial development projects in the Kyoto hillsides, halting dams or golf courses, resistance to the new railway station building and the rebuilding of Kyoto Hotel achieved little, other than perhaps discouraging further large-scale ventures. The Pont des Arts case marked the first time citizen groups triumphed in a city-center keikan ronsô. It should not be overlooked, however, that, with the sheer number of problems associated with the bridge plan, its perceived environmental and "cultural" - that is, nonpolitical - aspects, and the significant fact that the planned site was unmistakably public ground, the groups had been blessed with exceptionally favorable circumstances unlikely to be replicated in the future (Brumann 2002). 
As these examples have shown, citizen groups in Kyoto do have an impact, but they face a number of serious obstacles. The most important impediment is their shaky legal status: contrary to the practices of other countries, there are no tax exemptions for nonprofit organizations (NPOs) and for contributions to them under Japanese law, and the favorable legal form of a foundation (zaidan hôjin) is exceedingly difficult to attain since it is tightly controlled by central government agencies. In the aftermath of the Kobe earthquake, which pointed up the value of self-help efforts by citizen groups when state agencies fail, the so-called Nonprofit Organizations Law (NPO hô) was passed in 1998 to facilitate the workings of these groups. Since that time, nonprofit organizations have been permitted to incorporate, enabling them to execute contracts, open bank accounts, and the like. Obviously, this is a big step forward from the earlier situation in which these responsibilities fell to individual group members, with all the attending legal and financial risks. At the same time, however, these organizations continue to be taxed at the same rates as business corporations, and donations to them are still not tax-deductible. Also, while it has become highly popular to invoke borantia (volunteer) efforts as a remedy for a wide range of problems, there is still no culture of charitable donations that would allow for the kind of fundraising activities that, in turn, might put NPOs on a more stable footing, with adequate organizational infrastructure. As a consequence, none of the citizen groups I observed in Kyoto employs more than perhaps one part-time paid staff member, in marked contrast to their counterparts in Europe and America.

Probably because they are already fully absorbed by overcoming these structural problems, citizen groups in Kyoto also find it difficult to cooperate with one another. While the relatively successful environmental groups have formed several permanent coalitions, networking among townscape-related NPOs has never really taken hold even among those working on the same issue, such as machiya preservation. The bifurcation of the movement battling the Pont des Arts on political grounds therefore is not at all atypical and, while it may have helped to make the movement appear larger in this special case, it reduces the possible impact of citizen opposition in most others.

\section{Municipal administration}

During the press conference at which he announced the withdrawal of the Pont des Arts replica project, the mayor of Kyoto justified his decision by citing the harm that might be done to the spirit of pâtonashippu (from the English "partnership") between citizens and local government. With this loanword, he invoked one of the master terms of recent Japanese political discourse that has largely replaced previous expressions such as "citizen participation" (shimin sanka or jûmin sanka). Although the mayor's handling of the Pont des Arts conflict fell short of the ideal of citizen empowerment that pâtonashippu is referring to, it is indeed taken seriously by considerable segments of the municipal administration.

The best-known recent attempt to promote the new ideal is the Kyoto Workshop, a nominally independent foundation (zaidan hôjin) that is financed, however, by 
the city of Kyoto and staffed almost exclusively with its bureaucrats, who are delegated for three- to five-year terms. Established in 1997, the workshop strives to take part in the new wave in Japanese urban planning based on cases such as Taishido in Setagaya ward, Tokyo, or Mano in Kobe (see also Chapter 6). In this model, townscape disputes and urban planning in general are understood as predominantly interpersonal tasks for which establishing communication between all parties concerned - neighborhood associations, citizen groups, companies, experts, and, of course, the municipal administration itself - is considered crucial. The Kyoto Workshop engages in what is known as machizukuri, literally "townmaking" (also referred to by other authors as "community-building"), the "softer" counter-concept to the more technical term, toshi keikaku, which is usually used to designate urban planning in Japanese (Hein 2001; Hohn 2000: 367-492, 515-23; Sorensen 2002: 269-72, 308-25; Vogt 2001).

To this end, the workshop provides seminars and lectures, information, mediation, research and counseling services, and a bimonthly newsletter. In addition, its staff are skilled at organizing public events and in presentation techniques. In most of these activities, a congenial atmosphere prevails, with participants feeling free to voice their - often skillfully argued - opinions. Participants tend to play their accustomed roles, however; the university professor will not be asked to leave the expert's high ground and the neighborhood leader will not be challenged to adopt a translocal perspective. In addition, workshop staff carefully orchestrate all interactions between the participating groups and always remain in charge of the proceedings. Moreover, the implementation of the results of the communication processes is often only a secondary goal. When, for example, the Kyoto Workshop held a machizukuri contest for university students in 1998, inviting them to submit concrete projects for several neighborhoods to be coordinated with the residents, the resulting proposals were publicly displayed, duly admired, and published in lavish brochures. How realistic the proposals were, from a financial as well as an implementation point of view, however, never became a serious concern, either for the participating neighborhood residents and workshop staff or for a number of the students who freely dreamed up underground footpaths and other extravagant fantasies.

Encouraging and cooperating with citizen volunteer activities is a main goal of the Kyoto Workshop, and the foundation collaborates on a regular basis with both neighborhood associations and citizen groups - an attempt to integrate the two other models of local autonomy. One of the groups with which the workshop undertakes cooperative efforts is the Mokuzôkai; joint projects include a complete survey of all machiya within the boundaries of the historical city, conducted with the help of some 600 volunteers in 1998-9, and a number of public events such as symposiums, machiya visits with talks given by the residents, and a machiya craft fair. Cooperation fails to fully satisfy both sides, however. Mokuzôkai members have at times felt taken advantage of by the Kyoto Workshop, perceiving a reluctance to grant them an equal say in joint ventures. They also complain that the Kyoto Workshop unnecessarily doubles up their own projects, such as the machiya mediation service or the renovation manual, a lament echoed by other 
groups. In the eyes of the Mokuzôkai, public funds would be better spent on commissioning the citizen groups with such tasks. Kyoto Workshop personnel, however, claim that there are limits to the degree that, as a publicly funded entity staffed by public servants, it can entrust private initiatives with public tasks or share data with them. They are also of the opinion that the Mokuzôkai and other citizen groups focus too narrowly on particular interests and lack a larger perspective. Thus, after realizing that an ambitious home visit program for machiya residents interested in renovation exceeded the joint resources, the Kyoto Workshop aborted the program and refused to allow Mokuzôkai members to continue the visits on their own. This was a great blow to the Mokuzôkai, who saw the move as failing those machiya residents who had expressed an interest in such a visit. Despite the disenchantment voiced by both sides, however, cooperation continues, and Mokuzôkai leaders as well as members of other citizen groups see the Kyoto Workshop's existence as beneficial overall, especially since it gives them access to foundation resources such as its lecture hall. Full pâtonashippu, however, would require a greater readiness on the part of the bureaucrats to relinquish control. For the same reason, other citizen groups like those that fought the Pont des Arts replica are thoroughly suspicious of anything that comes under the name of pâtonashippu.

In any case, most of the public planning of the townscape preceded the advent of pâtonashippu, or remains little influenced by it, following instead what could be termed the "old model" of top-down planning in local government. Kyoto City pioneered a number of townscape protection schemes in the 1970s. One of these was the extension of inner-city "aesthetic zones" (bikan chiku) - originally a tool to bring about orderly modern townscapes (Sorensen 2002) - to encompass the preservation of the traditional urban landscape; another was the establishment of special preservation districts for historic architecture that later were also introduced into national law. Additionally, absolute height limits were retained despite national pressure to control the volume of individual buildings only by their floor-area ratio (FAR, or yôsekiritsu, defined as the total floor area of a building divided by the plot size). For most of the 1980s, however, government planning in Kyoto followed the national course of increasing deregulation, actively encouraging both the new railway station building and the rebuilt Kyoto Hotel and treating manshon disputes as private matters between developers and neighbors. Also, financial subsidies for the preservation of machiya and other historical architecture remained limited at best. The result is that, while the proclaimed goal of urban development since the 1990s has been "conservation for the north, revitalization for the center, and imagination for the south" (hokubu hozon, toshin saisei, nanbu sôzô), the local government has done very little to create the regulations and incentives that would realize this aim. Many citizen activists therefore see an essential lack of sincerity in such ventures as the Kyoto Workshop, convinced that, despite the honest intentions of its staff, their hands are tied: collusion between the Liberal Democratic Party (LDP) politicians now in power, top-level bureaucrats, and the construction and real-estate industry - the notorious "iron triangle" (Kerr 2001; McCormack 1996: 25-77; Woodall 1996) - will find ways to block restrictive planning, according to this belief. 


\section{Brumann}

\section{The three models intertwined: the aftermath of the Pont des Arts dispute}

The aftermath of the Pont des Arts project offers an instructive illustration of how unintended consequences can result when the three models of local autonomy interact. Despite his withdrawal of the proposed bridge replica in 1998, Kyoto's mayor confirmed his intention of building a - no longer French - footbridge in the same location, thereby implementing a long-standing city planning decision (toshi keikaku kettei) and responding to the demands of a vociferous group of east bank residents who had been pressing for a bridge connection all along. Nothing happened initially but, after the LDP victory in the following city council election, an advisory council (shingikai) was set up, meeting for the first time in July 2000. In Kyoto as well as elsewhere and at other government levels, shingikai are routinely summoned for developing recommendations on a myriad of questions, typically including academic experts, representatives of concerned industries and organizations, and nonspecialized intellectual and creative luminaries (bunkajin), typically about a dozen in all. Bureaucrats are considered the beneficiaries of the proceedings, listening in silence and responding to any questions directed to them. Some advisory councils in Kyoto, including the city planning shingikai, are permanent, although the majority are created as needed for a specific task, in this case discussing the future of the Kamogawa bridges. Although the council was supposed to consider all 38 bridges, developing ideas for the planned footbridge was an explicit part of the agenda and clearly became the main point of debate. Members of advisory councils in Kyoto are handpicked by the municipal administration and, depending also on the extent to which the often pre-agreed chair relies on the usually middle-level bureaucrats who act as a kind of secretariat, the council's nominal independence can become questionable. Still, the self-imposed standard of pâtonashippu has brought about a notable degree of change since the late 1990s. Today, shingikai are increasingly open to public audiences and, in most cases, two councilors - one male, one female - are selected from among ordinary citizens who apply for participation. Evidence of this trend was reflected in the shingikai established to address the Kamogawa bridges, with the minutes of the meetings published on the Internet. ${ }^{3}$ In addition, a leader of the Pont des Arts opposition movement's non-party wing was also made a councilor.

The purpose of the bridge shingikai was solely to debate the kind of footbridge that would be built, not construction as such. In addition, the chair, known as having endorsed the Pont des Arts replica, proposed a relatively short schedule to begin with, of only five meetings. This encouraged several councilors to enthusiastically dream up their own concepts for the design of the bridge. Maybe it had been believed by the city government that the single dissenting voice of the Pont des Arts opposition movement leader could be suppressed. This did not happen, however, given that another councilor - a university professor of urban planning and gifted public speaker - tenaciously pursued his creed of deepening the involvement of ordinary citizens in town planning matters. Since these citizens and the 
press were present at the sessions, there were few arguments the other members could make against his unprecedented idea of meeting representatives from the bridge site's vicinity and including them as panelists in a public symposium. Once legitimacy had been accorded to so many voices, however, it became very difficult to privilege those of the shingikai's members: in the sessions following the symposium, several members admitted to having underestimated how serious and emotionally charged an issue the bridge was for its neighbors.

It may be that the locals had also been counted on to remain docile but, if so, this did not prove true either: Pontochô business associations and the west bank jichi rengôkai now openly opposed the bridge plan. For one, resistance had shown its potential in the protest movement's victory against all odds and, with political, administrative, and economic leaders' expense accounts melting away in the economic crisis, their importance for local subsistence had decreased. Moreover, leadership within the associations had changed: the chairman of the jichi rengôkai, for instance, could neither be demoted nor overruled without embarrassing everyone when he opted against resisting the Pont des Arts replica project. When his tenure was up for renewal, however, none of the other office-holders proposed the customary extension; instead, a new chair opposed to the bridge plan was elected. As a result, when the expert commission held separate meetings with a number of local business and neighborhood associations whose domain bordered on the bridge site, a predictable picture emerged: associations on the east bank unwaveringly supported the bridge while the major associations on the west bank opposed it.

Thus, the advisory council dragged on over an unprecedented nine meetings and more than two years before, in 2002, it finally failed to muster the courage to recommend a particular course of action. Largely because of the Pont des Arts opposition activist's demands, the council's proposal (teigen) continued to be redrafted until the final version submitted to the mayor ${ }^{4}$ simply threw the ball back in his court: while enumerating the merits of a footbridge, it acknowledged the opponents' arguments and stressed local discord and the necessity of further discussion. It also pinned high hopes on the direct talks between west bank and east bank representatives that had been taken up after the symposium. The mayor announced that the proposal would have to be examined carefully before taking any action. Opponents were greatly relieved; some of them, however, also pointed out that building a bridge would have been very difficult in any case, since municipal budgets were already strained to breaking point. Seen in this light, the council may even have done the mayor a favor by not recommending immediate construction, thus allowing him to save face among the east bank residents who would hold him to his promise of erecting a bridge.

In considering the ways in which the three models of local autonomy and a fourth - the delegitimated but still persistent model of autocratic rule by "those above" (o-kami) - interacted in this case, a curious picture emerges: the old model of local government, which did as it pleased without consulting residents, had provoked the ire of the new model of civil society, the citizen groups that, to universal surprise, brought down the Pont des Arts project. Subsequently, pâtona- 


\section{Brumann}

shippu, as the new model of local government, returned the footbridge matter to the old model of citizen self-organization, the neighborhood associations. Both moves were certainly unplanned but, as they led to a predictable stalemate, the citizen groups did little to stop this development. However, they thus also helped to cede the footbridge question to local residents as a private matter, disregarding the larger citizenry's say over the destiny of this prominent piece of public space. In the advisory council, the voice of the public was only sought through a rather biased opinion survey, and the idea of holding a referendum was not even mentioned by the opposition representative who had actually worked for it during the Pont des Arts phase.

\section{Ultra-local autonomy: public and private control of land}

An observation made independently by a Pont des Arts opposition activist and a journalist for a JCP-related weekly provides another clue why citizen groups so readily relinquished their voice on this important issue: all their acquaintances whom they had asked for an opinion on the bridge plan felt urged to state that they did not live close to the bridge site before giving their answer. Even if unwittingly, they thus relativized their own views, giving precedence to those of the direct neighbors. Although the number of people who pass by, and no doubt appreciate, the bridge site every day is probably in six figures, citizens still deferred to an "owner" of the site, so to speak. It thus appears questionable whether there can really be such a thing as public space in Kyoto.

The view that land and the buildings standing on it are the private domain of the legal owner is deeply entrenched in Japanese legislation (Sorensen 2002: 156, 332,342 ) as well as in the popular consciousness, and there is nothing to indicate that this belief is any less strong in Kyoto. It also reaches well into the ranks of townscape-related citizen groups. When I interviewed her, a leading activist against the Pont des Arts replica and owner of a nearby restaurant censured the Bukkyôkai, an organization representing many temples important for tourism, for resisting the high-rise rebuilding of Kyoto Hotel. Given the value of the land on which it was standing, neither the proprietors in this case nor in that of the new railway station building could be expected to forgo an adequate return on their enormous investment. In another example, during the mid-1990s a controversy arose when it became known that one of the most famous machiya of Kyoto was to be torn down for constructing a manshon. Immediately, citizen activists started to collect signatures and organize an international appeal against the plan. Although leading Mokuzôkai members were divided in their opinion, several of them defended the right of the family of the owner to dispose of its property as it saw fit, and one of them even mediated the sale. The fact that one of the owners was a central figure in the management of a famous traditional festival and might thus be expected to defend cultural heritage did nothing to change this assessment. The city of Kyoto reacted similarly: when pressured by concerned activists to purchase the property and preserve it as public patrimony, the mayor objected, insisting that this could not be justified before other owners who might want their 
own property to be treated in the same privileged way. The building eventually was demolished. One urban planning professor involved in the issue suggested to me that making a public cause of the machiya was precisely what destroyed it. According to him, this only strengthened the owners' determination whereas, through more discreet negotiations, ways to save the house might still have been found. These are only a few examples of a surprisingly individualistic stance, running counter to what might be expected from a stereotypically "collectivist" society. It is the lack of consent from individual owners and the danger of heated protests that city officials invariably give as a reason for their being careful about imposing stricter regulations.

When considering the level of land prices that continue to be among the highest in the world, even after having dropped to less than a tenth of bubble-period peak values in central Kyoto, the defensiveness of real-estate owners against public interference becomes understandable. The value of the land often exceeds that of the building by far and despite falling prices is also more constant, given the inferior quality and short lifespan of much new construction and the small demand for resales. Much more than on the actual building standing on it, the value of a plot of land depends on the building potential, and this is reduced by any restrictions. Owners who simply want to continue living in their house and pass it on to their children will profit from declining land prices by saving on property and inheritance taxes. When there is an interest in the capital value of the house, however, such a decline is unwelcome. Often, owners only derive a vague sense of security from a sales potential that is not used, yet given that land remains the most important collateral for bank loans - banks first ask for real-estate, not income, when issuing credit cards - land prices become a concrete and vital concern for the many companies in central Kyoto that are deeply in debt. Creditor banks are not interested in a price slump either. In addition, the city of Kyoto profits since property taxes are one of the revenues it may pocket directly, and the national government as the recipient of inheritance taxes does not look kindly on any measure that cuts into its own resources.

This explains a great deal of the laxity of local and national building controls. The fact that buildings can only be designated as cultural property (bunkazai) with the consent of their owner, zoning regulations for central Kyoto that far exceed the actual average height and bulk of buildings, and a jurisdiction that treats the countless zoning infringements as trivial offenses and almost never orders the demolition of illegal structures all betray the shared interest of many citizens and both national and local governments in high land prices. Stricter limitations could also be expected to increase the attractiveness of an urban area so that prices recover and even rise in the long run, as exemplified by the gentrification of picturesque historic quarters all over the world. Still, this is as yet undemonstrated in Kyoto, and when it is the threats of impending bankruptcy or the actual depletion of municipal coffers that count, time horizons necessarily shrink. Also when interacting among themselves, ordinary citizens avoid interfering with one another's real-estate. The voluntary covenants (kenchiku kyôtei) over building rules that owners of contiguous lots may impose on themselves according to the Building 


\section{Brumann}

Standards Law (kenchiku kijun hô) are an underutilized tool in central Kyoto. In informal interaction as well, there are virtues in keeping silent about one's neighbors' construction activities. At the very least, one thus retains a moral right to build without inhibition, as was confirmed by two informants and city-center home owners who, despite being Pont des Arts opposition activists, had remained passive when their direct neighbors rebuilt their homes higher than they had wanted. The cumulative aspect of such deregulation and self-restraint, however, is the widely deplored townscape crisis.

In order to assess more precisely how the representatives of the different models of local autonomy view the property question, I distributed a questionnaire on townscape issues before the end of my first field stay, receiving it back from 210 informants. Table 7.1 juxtaposes the responses of four groups of respondents - Miyabiyama-chô residents, Kyoto Workshop staff, Mokuzôkai members, and anti-Pont des Arts citizen activists - to a number of questions touching on the control over real-estate and its value. Mokuzôkai members and Pont des Arts opposition activists are most alike in their opinions and lean most to those answers that imply greater public interference and control in such matters as height limitations, mutually binding building covenants, building designs adapted to the surroundings, or financial support for historic architecture. By contrast, among Miyabiyama-chô residents, such public-control views never achieve an absolute majority. Kyoto Workshop staff opinions in most cases fall in between. Miyabiyama-chô residents and Workshop staff, however, are most alike and at the same time most removed from the citizen groups on the one question that mentions enforcement, namely, the preservation of historic or scenic properties against their owners' will (legal in Germany, for instance). Japan's constitution gives the public the right to expropriate real-estate, and this is also put in practice, for example, in the construction of roads or airports. Extending the practice to historic townscapes, however, has not occurred thus far and would be likely to divide Kyoto's residents.

More surprising than the differences between groups, however, was the fact that, even among Miyabiyama-chô residents, views entailing the priority of private over public control achieve an absolute majority only once, over the question of public interference in machiya preservation. This is a matter that directly touches on these residents' interests since most of them actually own and live in such a house over which they claim free disposal. On other issues, however, those who favor public control of land and buildings are certainly more numerous than might be expected from the interviews and overheard remarks in Miyabiyama-chô and from city officials' warnings that citizen consensus had to be built before stricter regulations could be imposed. It may be that the private-control supporters are more outspoken, but it also could indicate a sign of change, with residents reconsidering their former views. The deepening crisis of the townscape, the construction of ever larger manshon, the growing prestige of traditional architecture, and, to a considerable extent, the plummeting land prices that reduce the importance of land as a capital asset cannot fail to have an impact on those residents who are continually exposed to these developments. If the city of Kyoto were to regulate zoning and construction more strictly, the public outcry would probably turn out to be far smaller now than what city officials appear to imagine. 


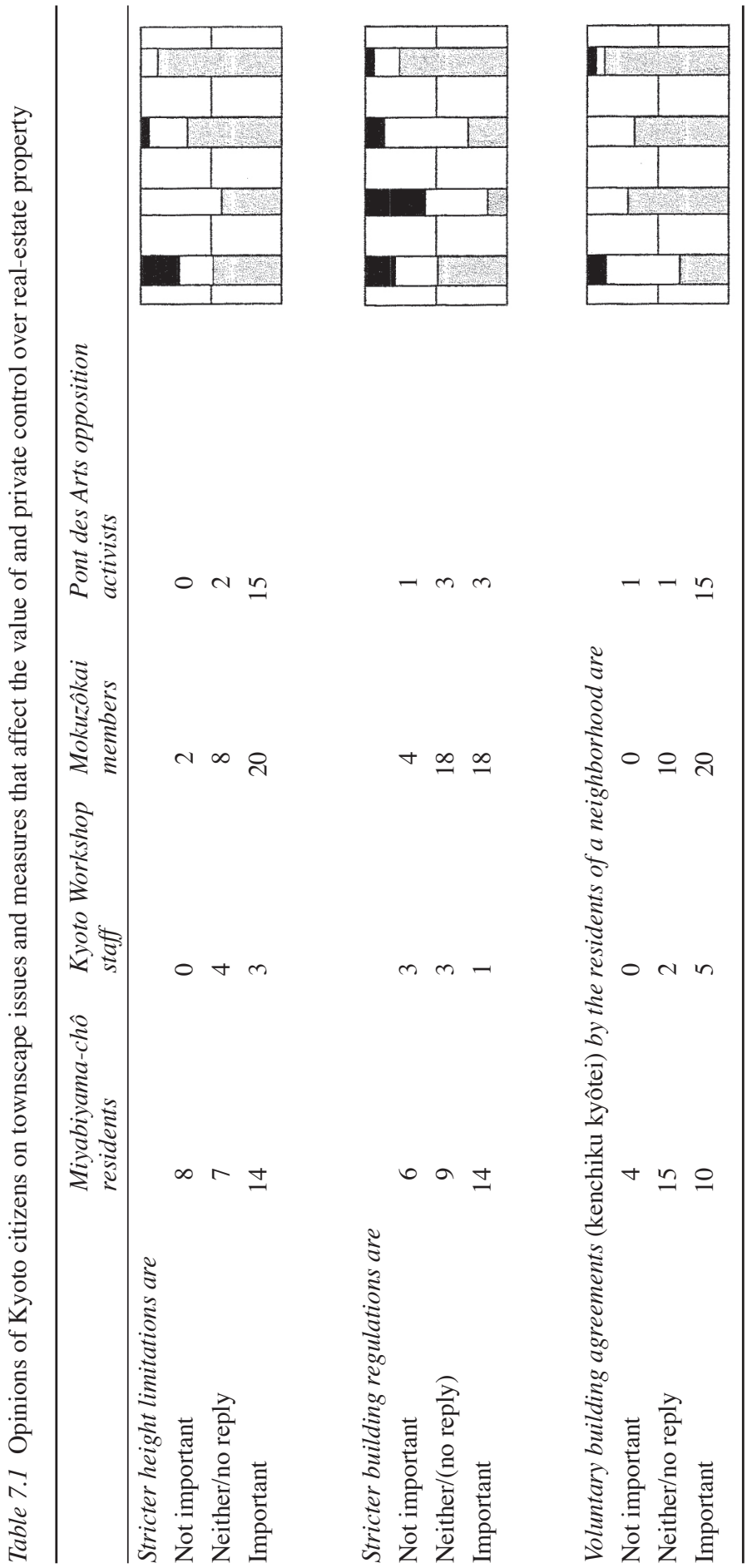








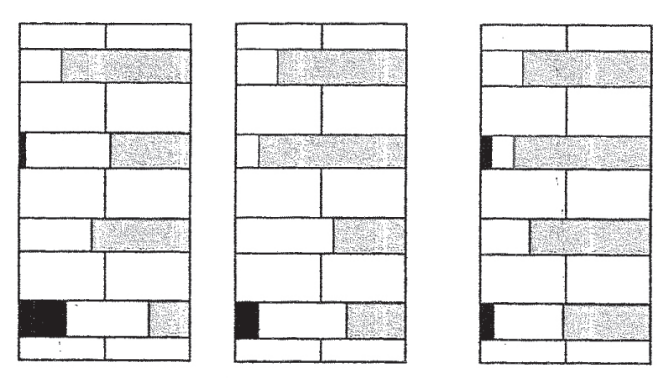



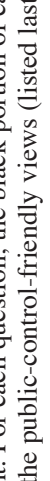

$0+m \quad 0+m \underbrace{}_{\substack{n \\ 0}} 0+m=$

蕠

일

ปี

.⿹ํ

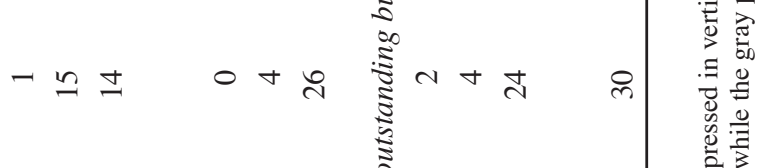

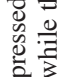

家

㐫的

告



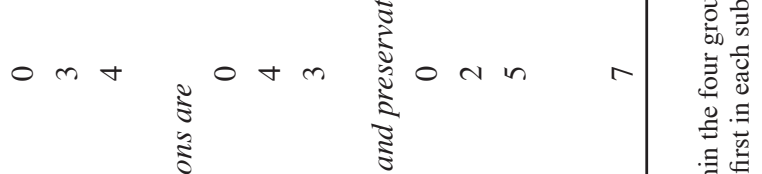

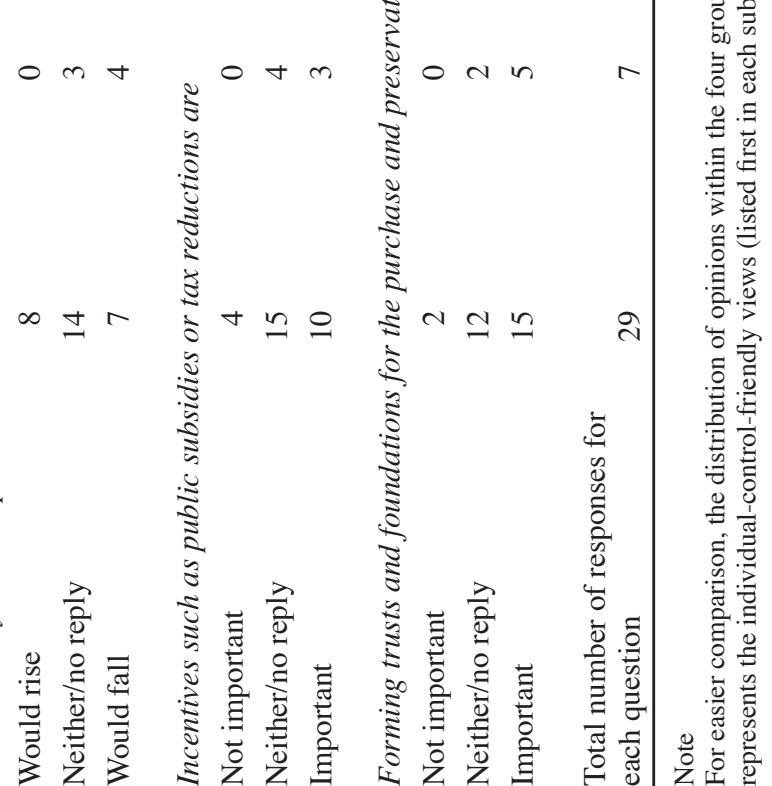


In fact, strengthening public control is what the city of Kyoto has embarked on, however carefully. After a number of manshon projects regarded as particularly appalling, unlikely candidates such as the standing city planning shingikai or major business leaders publicly voiced concern and demanded action. As a consequence, an advisory council was established to debate the future of the citycenter area, and worked more speedily than the council on the Kamogawa bridges. Based on the council's recommendations, municipal officials drafted several new ordinances, which were then adopted by the city council in $2002,{ }^{5}$ creating the first deviation from the course of deregulation pursued through the last three decades. In addition, fire prevention ordinances were eased for a number of areas densely packed with machiya so that rebuilding wooden houses and facades without pretending to merely repair a continuous building has become possible. In this latter move, the city made use of the amended Local Autonomy Law (chihô jichi hô), which allows municipalities wider discretion in modifying building regulations and other national laws. On the citizens' side, 2002 also saw the conclusion of the largest building covenant to date, involving approximately 100 plots on an area of two hectares, far exceeding the scope of any predecessor. This was brought about by the efforts of a machizukuri group that, while still having a local focus, makes a point of not sticking to the established territories and strategies of neighborhood associations.

These are clearly only tentative steps whose weaknesses are easily identified. The area in which height limitations have been tightened in 2002 is one from which the hub of the manshon rush has already retreated, and the height limits of the building covenant stand at 18 or 21 meters so that buildings of significant size are still possible. Even so, a trend long considered unstoppable is being reversed. What will follow is difficult to predict, especially since the rise and fall of land prices and of the economy in general depend on so many non-local factors. As one such non-local factor, a recent decision of the Tokyo District Court (Tôkyô chisai) could prove momentous: in the city of Kunitachi in the Tokyo agglomeration, citizen groups sued a developer whose newly built condominium they saw as destroying the scenic appeal of the tree-lined Daigaku dôri ("University Street"). In 2002, the court ruled that construction of the 44-meter-high manshon, even though conforming to the zoning regulations in effect when construction was started, exceeded a bearable limit for people living nearby. The court ordered the developer to remove everything above a height of 20 meters. The ruling has been repealed by the Tokyo High Court (Tôkyô kôsai) in 2004 but is likely to be appealed to the Supreme Court. Other courts too have upheld the public right on the townscape, and legislators have reacted swiftly: in 2004, the Diet passed a "Townscape Law" (keikan hô). With this law, not only is the townscape/landscape (keikan) appreciated as the "common property of the people" (kokumin kôkyô no zaisan) but "townscape districts" (keikan chiku) are also introduced in which, contrary to previous practice, building colors and forms may be prescribed in detail. Single structures important for the townscape can also be protected. In addition, the new law talks of incentives such as subsidies, tax breaks, and the transfer of floor-area ratio entitlements between plots of land, and it also allows 
residents to apply for "townscape district" status with the consent of two-thirds of the landowners within a given area. ${ }^{6}$ Much will depend on how these measures are put into practice and how they are applied to mixed zones such as Kyoto's center; radical change is certainly unlikely to occur. Nonetheless, the townscape and its protection now have a recognized legal existence - a fact whose importance can hardly be overestimated.

Whether these developments will help to save central Kyoto from further unplanned development, and when, is an open question; decreasing profitability of even the tallest manshon in a fiercely competitive market could have a faster effect. How the three models of local autonomy evolve in the future, however, is also decisive. Kyoto City will continue its course of pâtonashippu, even if only because, with exhausted finances, there is no way around delegating public tasks to the citizens. Neighborhood associations and the residents they represent will have to wean themselves from the private-property view, realizing how doing so can protect their interests rather than harm them, and how self-made regulations can improve the quality of life. Citizen groups working on the townscape will probably also have to increase their commitment. Typically, many of their leaders are people who come from outside Kyoto, often living in the suburbs. One Pont des Arts opposition leader told me how his having grown up elsewhere simplified his activism, giving him far less long-standing or fewer inherited social ties and obligations to consider. In order to have a voice in the development of central Kyoto that will be considered legitimate even by longtime residents, however, citizen groups must reach out to these residents and probably also acquire property in the city center themselves, perhaps by exploring novel models of joint or trust ownership. Only then would their claim that it is their Kyoto as well become irrefutable.

\section{Notes}

1 Funding by the Japan Foundation for the Promotion of Science (JSPS) during 1998-9 and by the German Research Association (DFG) during 2001-3 is gratefully acknowledged. I also wish to thank my academic hosts, Professor Nakamaki Hirochika and the National Museum of Ethnology, Osaka (Minpaku).

2 Following standard anthropological practice, the names of organizations in which personal informants participate have been changed, and details about personal informants have been left vague in order to ensure confidentiality.

3 See http://www.city.kyoto.jp/kensetu/gairo/gairoken/hashi/ (last accessed January 2005).

4 See http://www.city.kyoto.jp/kensetu/gairo/gairoken/hashi/teigen/index.html (last accessed January 2005).

5 See http://www.city.kyoto.jp/tokei/todu/matinami/newrule_new.pdf (last accessed January 2005).

6 See http://www.mlit.go.jp/kisha/kisha04/04/040209_2_.html (last accessed January 2005). 


\section{Brumann}

\section{References}

Berry, Mary Elizabeth (1994) The Culture of Civil War in Kyoto, Berkeley, CA: University of California Press.

Brumann, Christoph (2001a) "Machiya vs. manshon: Notizen vom Kyotoer Häuserkampf," Japanstudien 13: 153-92.

- (2001b) "Die Blumen von Edo: Zur Brandgeschichte japanischer Städte," in Kunstund Ausstellungshalle der Bundesrepublik Deutschland GmbH (ed.) Feuer (Fire), Cologne: Wienand, pp. 426-42.

- (2002) "Deconstructing the Pont des Arts: Why Kyoto Did Not Get Its Parisian Bridge," Senri Ethnological Studies 62: 15-24.

Dalby, Liza Crihfield (1983) Geisha. Berkeley, CA: University of California Press.

Hein, Carola (2001) "Toshi keikaku and Machizukuri in Japanese Urban Planning - the Reconstruction of Inner City Neighborhoods in Kobe," Japanstudien 13: 221-52.

Hoffman, Steven M. (1996) “The Influence of Citizen/Environmental Groups upon Local Environmental Policy Process in Japan," unpublished PhD dissertation, University of Wisconsin-Madison.

Hohn, Uta (2000) Stadtplanung in Japan: Geschicht-Recht-Praxi-Theorie, Dortmund: Dortmunder Vertrieb für Bau- und Planungsliteratur.

Iida Akira and Nanbu Takao (1992) Rekishi toshi Kyôto no hozen/saisei no tame ni (For the preservation and revitalization of the historical city Kyoto), Kyoto: Bunrikaku.

Ikegami Akihiko (1988) "Kaji: taika no rekishi: Nihon no kasai" (Fires: history of large fires: fires in Japan), in Heibonsha (ed.) Sekai daihyakka jiten (Global encyclopedia), Tokyo: Heibonsha, 5: 246.

Itô Munehiro (1994) "Chôgumi to jichi" (Chôgumi and local autonomy), in Bukkyo daigaku (ed.) Kyôto no rekishi 3: Machishû no yakudô (History of Kyoto 3: the rise of the townsfolk), Kyoto: Kyôto Shinbunsha, pp. 153-74.

Itô Takeshi (1993) "Toshi-shi no naka no saigai" (Catastrophes in urban history), in Takahashi Yasuo, Yoshida Nobuyuki, Miyamoto Masaaki, and Itô Takeshi (eds.) Zush û Nihon toshi-shi (Collection of maps and graphs on the urban history of Japan), Tokyo: Tôkyô Daigaku Shuppankai, pp. 308-14.

Kelly, William W. (1994) "Incendiary Actions: Fires and Firefighting in the Shogun's Capital and the People's City," in James L. McClain, John M. Merriman, and Ugawa Kaoru (eds.) Edo and Paris: Urban Life and the State in the Early Modern Era, Ithaca, NY: Cornell University Press, pp. 310-31.

Kerr, Alex (2001) Dogs and Demons: The Fall of Modern Japan, London: Penguin.

Kimura Manpei (1999) Kamogawa no keikan ga mamorareta: "Pon de zaru" shori no kiroku (How the Kamogawa scenery was saved: a chronicle of the "Pont des Arts" victory), Kyoto: Kamogawa Shuppan.

Krauss, Ellis S. (1980) "Opposition in Power: The Development and Maintenance of Leftist Government by Kyoto Prefecture," in Kurt Steiner, Ellis S. Krauss, and Scott C. Flanagan (eds.) Political Opposition and Local Politics in Japan, Princeton, NJ: Princeton University Press, pp. 383-424.

Löfgren, Karin (2003) Machiya: Architecture and History of the Kyoto Town House, Stockholm: School of Architecture, KTH Royal Institute of Technology.

McCormack, Gavan (1996) The Emptiness of Japanese Affluence, Armonk, NY: M. E. Sharpe.

Noda Hiroshi (1998) "Keikan/kankyô mondai to toshi no seijuku-ka" (Townscape/ environmental problems and urban maturation), in Bukkyô daigaku sôgô kenkyûsho 
(ed.) Seijuku toshi no kenkyû: Kyôto no kurashi to machi (Research on a mature city: life and city in Kyoto), Kyoto: Hôritsu Bunkasha, pp. 257-79.

Ôzuka Katsumi (1994) "Chûsei/kinsei: Machishû no matsuri” (Middle ages and early modern period: the festival of the townsfolk), in Takao Yoshii (ed.) Gion matsuri, Kyoto: Shôraisha, pp. 33-54.

Peternolli, Giovanni (1996) "Kyôto no imêji: Kako to genzai/Kyoto's image: past and present," in Giovanni Peternolli and Hashiramoto Motohiko (eds.) Rekishi-toshi no mirai: Daiikkai kokusai shinpojiumu/The Future of Historic Cities: an International Symposium, Kyoto, 7th and 8th October 1995, Kyoto: The European Cultural Institutes in Kyoto (Britain, France, Germany, Italy) and Kyoto City, pp. 103-10.

Salastie, Riitta (1999) Living Tradition or Panda's Cage? An Analysis of the Urban Conservation in Kyoto. Case Study: 35 Yamahoko Neighbourhoods, Helsinki: Helsinki University of Technology.

Sorensen, André (2002) The Making of Urban Japan. Cities and Planning from Edo to the 21 st Century, London: Routledge.

Takamichi Masai (1993) “High Structures Lower Kyoto's Horizons,” Japan Quarterly 40: 79-85.

Tani Naoki and Masui Masaya (1994) Machi/Gion matsuri/sumai: Toshi sairei no gendai (City/Gion matsuri/dwellings: the present of an urban ceremony), Kyoto: Shibunkaku shuppan.

Ueda Atsushi (1991) “Can Kyoto be saved?" Japan Echo 18: 80-4.

Vogt, Silke (2001) Neue Wege der Stadtplanung in Japan, Partizipationsansätze auf der Mikroebene, dargestellt anhand ausgewählter Machizukuri-Projekte in Tôkyô (New methods of urban planning in Japan: participatory approaches on the micro-level in selected machizukuri projects in Tokyo), Munich: Iudicium.

Wakita Haruko (1999) Chûsei Kyôto to Gion matsuri: Ekijin to toshi no seikatsu (Medieval Kyoto and the Gion matsuri: the god of epidemics and urban life), Tokyo: Chûkô Shinsho.

Watanabe, Hiroshi (1994) "Kyoto fragments: Divisions and discontinuities in an ancient city," Japan Quarterly 41: 416-33.

Woodall, Brian (1996) Japan Under Construction: Corruption, Politics, and Public Works, Berkeley, CA: University of California Press.

Yoneyama Toshinao (1974) Gion matsuri: Toshi jinruigaku no kotohajime (Gion matsuri: urban anthropological beginnings), Tokyo: Chûkô shinsho.

-(1986) Dokyumento Gion matsuri: Toshi to matsuri to minshu (Gion matsuri documentation: city, festival, and people), Tokyo: Nihon Hôsô Shuppan Kyôkai.

Yoshii Takao (ed.) (1994) Gion matsuri, Kyoto: Shôraisha. 


\title{
8 Conclusion \\ Decentralization policies - questioning the Japanese model
}

\author{
Carola Hein and Philippe Pelletier
}

In the course of the many centuries during which Japan's highly centralized governance structure has existed, multiple ties have formed between national and local institutions, providing each actor with a precise role and inherent security. The relationship between the various levels of Japanese government is not as hierarchical and top-down as it appears at first glance, and recent scholars have focused on its nuances. ${ }^{1}$ Senior Japanese political analyst and professor of law Muramatsu Michio points out the interdependence of all parties in regard to a common national objective, that of economic mobilization, and stresses the systematic exchange of information between different levels of government and the search for consensus (Muramatsu 1997; Ishimaru 2000). The mobility of agents of the Ministry of Local Affairs (Jichishô), who go during the span of their career from the office of one local government to another and back to the central ministry, is recognized as a practice that allows for coordination between all partners. Public administration scholar and professor of law Akizuki Kengo goes even further when he proposes that the financial relationship is in fact based on a conscious bargaining between the two, with the national government being stronger, but also having to foot the bill for local governments if necessary (Akizuki 1995).

Given the complex connections between the national and local levels, the meaning of decentralization (chihô bunken) and the socio-political and economic processes it encompasses merit analysis. Decentralization is a multifaceted issue, intimately linked to a variety of aspects of Japanese society. It is thus necessary to break up this entrenched system to effectively transfer more political decision-making functions to local entities - a subject discussed by Ishida Yorifusa in Chapter 2 of this volume. Equally important is a reorganization of the financial relationship between the center and the periphery, the structure of which is analyzed by Alain Schebath in Chapter 4, as well as a citizenry knowledgeable about planning and related issues in order to allow them to contribute more substantially to local planning as André Sorensen, Watanabe Shun-ichi, and Christoph Brumann point out in Chapters 5, 6, and 7, respectively.

So far, it appears that attempts at decentralization have reflected national interests and needs more than those of the localities - including, to some extent, Tokyo. The national government has made attempts to decentralize in times of crisis: for example during World War II when it built new towns and relocated some military 
facilities and other institutions in preparation for aerial attacks; in attempts to grant favors to localities important in political and election campaigns, for example during the so-called "rapid growth" period, when tax revenues were funneled back to particular areas in the form of public-works projects; or as a means to promote industrial growth and the agenda of major industries, for example through the Technopolis Plan during the 1980s as has been seen in Chapter 1.

Decentralization attempts at the national level and pressures from below, while having a long history, have not led to effective results, and the multitude of local organizations (chônaikai) has largely been co-opted into a strict national hierarchy, as Ishida, Schebath, and Sorensen point out. Citizen initiatives address movements and aspirations emanating from the grassroots level (Evans 2002). These, however, are generally small, with only local input, as demonstrated by Sorensen and Brumann; and the education of citizens is inadequate to the task, as Watanabe suggests. The government appears to oppose the formation of national movements that are local in origin (such as the Green Party in Germany). All these factors seem to indicate that decentralization is first of all an idea and a function of national government interests. The position of the capital city, Tokyo, is particularly relevant in this context. The deconcentration policies in Tokyo are not primarily the outcome of attempts to restructure the city itself and improve the quality of life for its citizens, but reflect the results of national spatial redistribution schemes and a recentralization that has in fact accompanied decentralization policies since the 1960s, as well as the discussions of a multi-core structure for Tokyo, a topic that is analyzed by Nakabayashi Itsuki in Chapter 3.

The following sections examine the theme of decentralization and the recent growth of local initiatives, and how they play out between the national government and Japanese urban space, most importantly in regard to the capital city of Tokyo. An investigation of decentralization projects, and the discussion surrounding them, which have flourished since the 1990s, highlights the complex issues involved. An examination of recent large public-works projects in Japan demonstrates how financing of local infrastructures strengthens the center, a long-term strategy that is recently running into conflict as local initiatives oppose large-scale national interventions. Special attention is given to the particularities of Tokyo as a municipality, as the tensions between the national government and cities appear most clearly there. All of these themes come together in the debates around a possible move of the capital city function, which can be seen not only as a major decentralization initiative but also as a public-works project led by the national government. The construction of a new capital would mean a major disruption for the Japanese system, one in which various governmental levels are intimately intertwined and enjoy a mutually beneficial relationship with private entities. The difficulties inherent in implementing decentralization in Japan illustrate the singularities of the structure of the Japanese system.

\section{Decentralization as catchphrase}

The theme of decentralization took on renewed significance during the 1990s with the implosion of the 1955 system, based upon the Jimintô Liberal Democratic 
Party (LDP), which dominated Japanese politics for most of the second half of the twentieth century. The end of this long-lived system was symbolized by Hosokawa Morihiro's arrival in power in August 1993. Hosokawa, a former governor of the Kumamoto prefecture (Kyûshû), was a longtime advocate of decentralization and as prime minister from August 1993 to April 1994 he promoted this measure. The new Law for the Promotion of Decentralization (chihô bunken suishinhô), passed in May 1995, and the attendant creation of the Committee for the Promotion of Decentralization (chihô bunken suishin iinkai), demonstrated the growing interest in the issue.

A large gap exists, however, between the official language and the concrete functioning of decentralization. In the 1990s, "decentralization" devolved into a catchphrase seemingly intended to resolve a variety of problems, including excessive centralization in the face of the persistent call for decentralization, administrative heavy-handedness, the feudal behavior of ministries, insufficient autonomy of local governments, the crisis situation of local finances, and problems of distribution of taxes and other resources. While these criticisms were widely shared, opponents had differing agendas. Partisans of deregulation within conservative political parties, the so-called Neo-Liberals who attacked the central government, saw decentralization as going hand-in-hand with a reduction of taxes and the transfer of funding for social programs to citizens, and thus to local governments. The desire for local participation as expressed by the left-wing Social Democrats and by members of the Japan Communist Party (JCP), the former Socialist Party and the new Democratic Party, may have corresponded - as it may for the current Liberal Democrats within the LDP - with the wish to preserve a protectionist system based on the compromise of state capitalism.

The dichotomy between the views of Neo-Liberals and Social Democrats in terms of decentralization has been discussed by the scholar Brendan F. Barrett of the United Nations University/Institute of Advanced Studies, following Japanese authors such as Shigemori Akira, who see it essentially as responding to the political forces of the right and left (Barrett 2000; Shigemori 1998). Their analysis is based on the commonly held belief that political discourse reflects ideological opinion rather than the material reality of power or the concrete interests of those in power. The techno-bureaucracy that holds power, and which includes political parties of all persuasions, administration, and consultants, survives on public monies and has as its goal self-perpetuation. Therefore, it is not clear that the divergent views can be clearly attributed to a division between right- and leftleaning political beliefs.

Encouraged by Hosokawa's appearance on the political scene, a new party called Sakigake - an offshoot of the LDP, established in 1993 by Takemura Masayoshi (former governor of Shiga) with Hatoyama Yukio (then representative of Hokkaidô) - had the potential to establish a center-right national government with a strong decentralization policy, building on non-Tokyo leaders. Hosokawa's downfall after a brief tenure, however, led to a reinvigoration of the traditional parties. The Democratic Party (Minshûtô) spearheaded by Kan Naoto and Hatoyama Yukio in 1996, which absorbed the Sakigake before integrating the Liberal Party 
(Jiyûtô) of Ozawa Ichirô in 2003, could have best represented decentralization tendencies, but was too focused on the party's interior struggles. Simultaneously, supporters of Hosokawa and Takemura, who had been eliminated from the political scene, integrated citizen movements and tried to become influential on the local level.

According to sociologists Richard Child Hill and Kuniko Fujita, despite deregulation and privatization trends following globalization since the 1990s, the public sector in Japan continues to play a major role in the economy. The gross fixed capital formation is three to four times higher than in other industrialized countries, and the role of local governments in social investments combined with that of the central government remains high (Hill and Fujita 2000). The already high ratio of public investment to GNP in Japan even increased, from 4.5 percent in 1965 to 7.5 percent in 1995, during the so-called neo-liberal period, while it decreased in other industrialized countries. Similarly, the financial support given to social protection (health, retirement, social programs, unemployment, and so on) increased by 90 percent between 1980 and 1990, and by 65 percent from 1990 to 2000 (Hill and Fujita 2000). Furthermore, the mounting debt carried by local governments has become a way for the central government to shift its enormous debt burden to the local level. In the 1990s, Japanese local governments experienced a difficult financial period during which they saw their debt grow from 15 percent of GNP in 1991 to more than 35 percent in 1999 (see Alain Schebath, Chapter 4). Borrowing, which accounted for 8 percent of total local budgets in 1990 , increased to 15 percent in 1998 . The main cause of the rising local debt burden was a paucity of resources that accompanied the economic downturn during this time, coupled with the maintenance of the level of expenditures established during the "bubble" period (1985-90). Decentralization is thus first and foremost a function of national government needs, underscored by government's heavy investment in public works in the provinces.

\section{Strengths and weaknesses of the "state-as-builder" concept}

Local governments since the bubble period have spent large amounts on the construction of buildings and public works. The central government has encouraged this behavior through a series of plans, such as the 1989 economic revitalization project aimed at investing 630 billion yen over a period of 10 years in infrastructure works. These endeavors were based on the conception of the "state as builder" (doken kokka) or the "civil engineering state" (doboku kokka), as the Ministry of Construction, which was in charge of urban planning after 1945, brought national policy decisions to the local governments. According to Kajita Shin, a Japanese economic geographer, in fiscal year 1995, 80 percent of the total public investment went to civil engineering works, with 75 percent of the total investment in the civil engineering industry deriving from government agencies (Kajita 2001). According to Gavan MacCormack, a specialist in Pacific and Asian studies, the construction and public-work sectors employed some 7 million people, or 10 percent of the Japanese workforce (MacCormack 2002). 
They account for the equivalent of 8 percent of the GNP annually, which is two to three times more than that of other countries in the Organization for Economic Cooperation and Development (OECD), of which Japan is a member. The functioning of the public-works sector is often opaque as construction arrangements are often established before an official bid (dango) is tendered. The political and administrative leadership as well as the unions tacitly acknowledge this system, which generally works to the benefit of all concerned.

One of the major strengths of the construction and public-works system is a strict economic, social, and political hierarchy that separates the six major building firms from the other 90 percent of the sector, composed of small and mediumsized enterprises with capital of less than 10 million yen; the salaried employees from the day-workers, who may number as much as one-third of the workforce; and the metropolitan center from the local governments in rural areas, where economic activity, social stability, and political life depend largely on construction work provided by the central government. Using the example of Shimane-ken, a prefecture in the remote San'in area, Kajita Shin has demonstrated how, from an initial workforce made up of successive generations of laborers who have remained in rural areas, local civil engineering companies have created a system of de facto prefectural interdependence. Because local governments are the primary funders of infrastructure construction, which often represents more than half the public-sector expenses (both national and local), they play a major role in mediating between the national and local levels (Kajita 2001).

Since the Meiji period, the government has given priority to the construction of infrastructure - roads, followed by highways; railroads followed by high-speed railways; bridges and tunnels; and harbors and airports. These interventions are partially derived from the historical necessity to control an environment with a high risk of natural disasters, and the destruction that may follow, and the need to connect the various parts of a mountainous island nation where travel was not easy. It also reflects the desire to promote industrial production above social welfare. Furthermore, it points to a policy of revivifying the economy through public works, particularly after 1973, when fiscal conservatism made room for Keynesian activism, and especially in the 1980s, with the introduction of neoliberal politics, particularly deregulation and privatization (Mochida 1993).

Public works allowed local elites to direct funding toward election finances, engage in corrupt practices, and create a techno-bureaucracy that responded to their needs (Woodall 1996). The connections between the LDP and the construction and public-works sectors were particularly marked in the Tanaka-TakeshitaHashimoto faction, which had held sway over Japanese political life from the early 1970s to April 2001, until the election of Prime Minister Koizumi Jun'ichirô, who broke with the old factional logic. The LDP thus guaranteed a certain amount of public investment funds in exchange for the political and financial support of the public sectors. There are numerous examples of elected and public-works officials who have later been present in the Ministry of Construction and its public-works satellites (a system called amakudari), while former employees of the ministry have become leaders in the public-works sector. ${ }^{2}$ 
The Japanese government has a long history of construction projects built at a loss. Among the most spectacular "white elephants," as the Japanese press deems them, are three viaducts over the Inland Sea. Proposed in 1958 by the Ministry of Construction, these spans were approved under the New (second) Comprehensive National Development Plan of 1969 (Shinzensô); confirmed in 1972 under Prime Minister Tanaka Kakuei's Nihon rettô kaizôron or kaizôron, a project for the remodeling of the Japanese archipelago that laid out guidelines for regional development including the construction of bullet trains and industrial complexes; reconfirmed by the Third Comprehensive National Development Plan of 1977 (Sanzensô); and finally built between 1985 and 1999, at a cost of 3.36 billion yen (1.13 billion for the Kojima-Sakaide connection alone) (Pelletier 2001). The traffic on these toll bridges, however, has turned out to be much lower than anticipated and they currently operate at a deficit. The corporation controlling the Seto Bridge, where traffic is two and a half times less than projected, has a debt of 4 billion yen. A similar case is the Seikan Tunnel, the longest in the world, proposed in 1964 by the Japan Railways Construction Public Corporation, which was linked to the former Japan National Railways (JNR) and opened in 1988 under the Tsugaru Strait. Although the tunnel came in at a cost of 1.1 trillion yen, traffic has not reached expected levels. Although often presented as examples of decentralization and central government sponsorship of remote areas, these projects have generally promoted centralization by making traffic more efficient and faster, increasing the range of areas that can be reached on a day trip from the capital city. While local economies only partially benefit from these investments, many local LDP leaders favor projects that are financially supported by national investments. Meanwhile, the indebtedness of the four public highways corporations (Nihon dôro kôdan, Shuto kôsokudôro kôdan, Hanshin kôsoku dôro kôdan, and Honshû-Shikoku renrakkyô kôdan) is immense: 40 trillion yen in 2004, reimbursable over a period of 40 years.

Despite the end of the bubble period in 1990, which led to a major financial crisis for the government and the public-private banking system and to greatly increased public debt (58 percent of the Japanese GNP in 1995, up to 140 percent in 2001), successive governments have continued to initiate public-works projects. The most recent New Comprehensive National Development Plan, the fifth, prepared by the Hashimoto Ryûtarô government in 1998, maintains this policy, anticipating the construction of larger dikes to protect against the flooding that has recurred approximately every 200 years, new dams, and giant bridges over several bays, as well as 3,000 kilometers of highways and new lines for bullet trains. The profitability of these projects is highly questionable given the heavy deficits of this type of investment.

To date, the state-as-builder notion has remained remarkably constant over time, including the neo-liberal era initiated by Nakasone Yasuhiro's government in the mid-1980s. Its future lies in the hands of an investment and loan program (Zaisei tôyûshi, also known as Zaitô), under the aegis of the Trust Fund Bureau of the Ministry of Finance (MacCormack 2002). The funds that the Zaitô administers come from major public savings funds (pensions, life insurance programs, 
postal savings), and are invested in large infrastructure and public projects. They often account for half the general budget of the national government (Udagawa 1983). The Zaitô, as a result, serves as the financial provider of the national spatial planning system. The funding for these expenses necessarily comes out of other budgets, such as social spending, or by a reduction in the number of government employees. Under discussion by the Koizumi government are the privatization of the postal system, planned for April 2007, and of four Japanese highway companies (including the Seto Inland Sea bridges corporation) planned for 2005, two important pillars of the state-as-builder system. But, at the local level, the system is starting to change as demand for new infrastructure is decreasing in rural areas, where more workers are leaving their home towns, as shown by the example of Shimane-ken (Kajita 2001).

While the state-as-builder policy is ubiquitous in Japan - on seafronts and beaches, in canals and dams (more than 580), on the slopes of volcanoes, and even in dense forests - citizens began in the mid-1990s to challenge these projects. More and more frequently, they advocate dispensing with greater protection from natural disasters in favor of a greater sensitivity to issues of environmental pollution and quality of life, including green space, recreation areas, and public spaces. The new hostility of inhabitants toward these projects can be seen in the vocal, local opposition to the construction of the Yoshino River estuary (in Tokushimaken, Shikoku) and the reclamation of land in a part of Ariake Bay (in Isahaya, Nagasaki-ken, Kyushu), which have gained national support.

The above examples, as well as a series of local citizen initiatives on a variety of issues - including the presence of a military base, the construction of nuclear facilities, and the location of dumpsites - raise the question of local democracy in Japan. While the participation in national elections continues to fall (approximately 40 percent), the number of people participating in referendums can reach a very high level (up to 80 percent). In addition, this has translated into a new kind of local politician, less dependent on national directives, and a rejection in general of the government bureaucracy in Tokyo.

Citizens who are being asked to pay higher taxes without being consulted on construction projects that affect them are angry and local politicians are beginning to object to the choices of national or prefectural administrations. Thus, the popular governor of Nagano, Tanaka Yasuo, in his "Manifesto Rejecting Dams" (Datsu damu sengen) issued in February 2002, opposed technocratic solutions and called for green dams able to absorb typhoons and floods (Asahi Shimbun-sha 2004: 220). As of 2006, as a result of citizen opposition and changes in the attitudes of local politicians, construction on 11 major dams has been halted. The time when opposition movements went unnoticed is clearly past. ${ }^{3}$ It is not certain, however, that the calls for an end to the state-as-builder concept and a reinforcement of local institutions are not also being accompanied by privatization in various arenas that will ultimately imply an even higher debt for the already troubled local governments. At the same time, the public-works sector is strongly opposed to changes of any kind. 


\section{Tokyo: a unique local government}

Of the numerous local entities, currently 15 major cities, all of which contain more than 1 million inhabitants, have the special status of Cabinet Odinance Designated Major Cities (seirei shitei toshi) - a classification created by the Local Autonomy Law, based on a 1956 statute and given to cities with a population greater than 500,000, which has important economic and industrial implications. These cities are now 15: Ôsaka, Nagoya, Kyôto, Yokohama, Kôbe, Kitakyûshû (1956), Sapporo, Kawasaki, Fukuoka (1971), Hiroshima (1980), Sendai, Chiba, Sakai (1989-92), Shizuoka (2005) and Sakai (2006). An even more special status characterizes the metropolis of Tokyo (Tôkyô-to), which occupies a unique status as both a prefecture and a large city. Its 23 wards have rights similar to those of the 15 special-status cities. Tokyo thus occupies a singular role in Japan in both administrative and economic terms (Toki 1992; Fujita 2003).

The attraction and power of the city of Tokyo are intimately intertwined with the presence of the national elite. Tokyo is home to major architectural experiments and a very dynamic public sector. The city is also often the recipient of national government funding, notably for infrastructure construction, as well as being the center of the government itself and the seat of representation for local and provincial offices, which negotiate with central economic and political authorities. Until the advent of the debate on decentralization in the early 1990s, Tokyo's administration had resembled the feudal system of sankin kôtai. But while the city, as the Japanese capital, has a unique relationship with the national government, it also operates under a local government. The metropolis of Tokyo has the highest income and expenditure level among all local governments in Japan; at the same time, like other local governments, TMG is in dire financial straits, more so, in fact, than most other cities.

At the beginning of the 1990s, the financial crisis in Tokyo was largely a result of shortsightedness on the part of national authorities who, by refusing to acknowledge that the economic bubble had burst, laid the groundwork for the political shock that came in 1995 with the election of two candidates, former theatrical actors, who were not part of the political establishment, as governors of the major cities of Tokyo and Osaka. The office of governor is that of an interface between the local and the national level: as chief of the prefecture, so charged by the national government, the office-holder is that government's legal representative. Because the governor can only be removed from office by the central government using judicial means, this office-holder enjoys relative stability. Governors are often former members of the national ministries, a practice known as amakudari. ${ }^{4}$ Their policies are based around the concept of consensus and the building of a wide range of alliances, extending beyond the national level and to many political parties (even those of the opposition) as a way to share part of power beyond party lines (hence the Japanese expression for this practice, ainori, which translates as "jumping aboard"). This collaboration puts into doubt the effective competition between national parties and has led to the popular impression that the winners have already been decided before the elections, which means low 
voter turnout at gubernatorial elections and generally low expectations on the part of the citizenry. Changes, however, are beginning to occur as more "outsiders" accede to the position.

The new governors, Aoshima Yukio in Tokyo and Yamada Isamu (nicknamed Yokoyama Nokku) in Osaka, were a contrast to the old. Aoshima followed a governor who, as an "independent" but with close ties to conservative groups, had served four terms. Tokyo's new governor presented himself as an anti-politician, denouncing secret negotiations and the destruction of democracy. During his campaign he had criticized large-scale urban projects such as the so-called Waterfront Sub-center (Rinkai fuku toshin), one of the nuclei created within the Tokyo metropolis in an attempt to alleviate pressure on the center and thus forming part of the deconcentration attempts, and the Tokyo world fair, entitled "Tokyo Frontier," projected for 1996. After the election, Aoshima canceled the fair, but was obliged to continue the sub-center project, already under way (Saitô 2003; Pelletier 1998; Scoccimarro 1998). He had only limited success as governor and, contrary to his election promises, left an even higher debt level than his predecessor. Aoshima did not run for reelection, a retreat that opened the door for a new candidate outside the "traditional" ainori system, the unaffiliated Ishihara Shintarô, who was elected governor of Tokyo in 1999 and reelected in 2003 (Jain 1999).

Ishihara's career and life are emblematic of the important changes occurring in Japan during the past decade. Born in 1932, the governor is emblematic of the postwar generation. ${ }^{5}$ After becoming a well-known writer and subsequently a politician within the LDP, he received international notoriety as co-author (with the president of Sony, Morita Akio) of the book The Japan That Can Say "No" ( "No" to ieru Nihon) in 1989, which criticized the inability of Japanese leaders to resist economic pressure from the United States (Ishihara and Morita 1989). Among other similarly oriented texts, he co-wrote with Etô Jun in 1991 The Japan That Can Firmly Say "No" (Danko "no" to ieru Nihon) - earning him the title of "Mister No" (Ishihara and Etô 1991). It is important to note that saying "no" overtly is extremely uncommon in Japanese society and in the rare cases that it is used it is interpreted as a show of strong character.

Having left the Diet in 1995, Ishihara campaigned in 1999 under the slogans "Change Japan from Tôkyô" and "The Tôkyô that can say 'no'," promising to reduce the deficit. He requested the return to Japan of the Yokota military base, which was used by the US Army, suggesting it be turned into a third airport for the city. He criticized the timidity of Japanese leaders in regard to China and the United States, and rejected, among other things, the Chinese version of the massacre of Nankin (1937-8). As a longtime politician he capitalized on his image as a straight speaker to attract uncommitted voters (who previously had voted for Aoshima Yukio) and was elected by a substantial margin.

As governor, Ishihara rapidly slashed the city's budget (public housing, new subway lines, and the like) and reduced the number of local government employees. ${ }^{6}$ Under his tenure the Tokyo Metropolitan Government (TMG) accelerated the construction of office buildings and housing and deregulated urban planning 
laws, in particular the plot area ratio (kempei ritsu). ${ }^{7}$ In this context, Ishihara's urban policy can be tied to that of the Koizumi government on a national level, in which the enforcement of the deregulation of urban planning has been touted as promoting "urban regeneration" (toshi kûkan saisei). For example, the plot area ratio in the Shiodome area jumped to 1,200 percent in a few years until 2005. The urban fabric of the 23 wards that comprise inner Tokyo is rapidly densifying and taller buildings are being constructed (Ishida 1998). In the early 2000s, the TMG even initiated plans, together with the railway company Japanese Railway (JR), Mitsubishi, and other companies, to commercialize air rights over buildings. A goal of Ishihara and the TMG is to boost the use of Tokyo's Haneda Airport and further extend it into Tokyo Bay, a project that has huge financial and environmental implications not only for Tokyo but also for the neighboring prefecture of Kanagawa. The new Ministry of Land Infrastructure and Transport projected the final, total cost (2003-7) at 900 billion yen, based on one-third shared with local communities (Asahi Shimbun-sha 2004: 240). This has met with ongoing protest from the TMG, which is currently engaged in negotiations with the national government.

Overall, these plans mean densification and an increase in urban renewal toward the south and southeast of the traditional central business district along Tokyo Bay in the Chûô and Minato wards. ${ }^{8}$ After many years of disputes following frenetic speculation, a new urban project was inaugurated in 2003 on the triangular site of the former JNR railway depot in Shiodome: the "Media City Shiodome," destined to house electronic business headquarters (Matsushita), a transport center (Nippon Express), media headquarters (Nippon TV and Kyôdô News Service), hotels, housing, and other activities (Hohn 2002). Simultaneously in the mid-2000s, corridors of information enterprises are developing inside the city. The high cost of renovated spaces close to the city center (6.83 million yen per square meter in Shiodome versus 1.13 million in Rainbow Town - the new name of a part of the Rinkai fuku toshin sub-center) highlights the recent recentralization of tertiary functions.

Ishihara is also notable for his nationalistic - even xenophobic - and militaristic views. He made a series of controversial visits to the Yasukuni sanctuary, which honors the souls of Japanese soldiers who died in combat as well as those of war criminals executed after 1945 (Yoneyama 1999; Hein 2004). He met with the Taiwanese leader, Lee Teng-hui, in November 2000, resulting in protest from the People's Republic of China, and in February 2003 declared his support for the United States in its war in Iraq. His leadership of Tokyo serves as a platform from which he has promoted his ideas for the Japanese nation, apparently convinced that if the national government cannot adequately respond to US economic and global policies, then it is up to local governments to do so. While some of his positions have provoked strong criticism from Tokyo citizens and neighboring countries, Ishihara was easily reelected in April 2003 (with 2 million votes, 72 percent of the total number of voters), with double the votes he received in his first election. Voter absenteeism, however, increased during this election, rising to more than 50 percent of voters. Although this phenomenon is typical of Japan as 
a whole, it also signals the limits of Ishihara's popularity. ${ }^{9}$ While the election and reelection of Ishihara are significant as an expression of a radical political right wing re-emerging, this has coincided with the strong growth of volunteerism, citizen movements, and various popular associations.

\section{Moving the capital: a debate that highlights the system}

The progression of economic concentration within central Tokyo (tertiary functions) as well as in the larger Tokyo metropolitan area (industrial functions) has given rise to public debate about the need to create a re-balance of inhabitants, economic activities, and infrastructure on the Japanese archipelago and invites the question of relocating capital functions. In the mid-1980s, the Japanese media, some political circles, and a number of intellectuals raised the issue of moving the Japanese capital away from its current site in Tokyo. Whether or not the move of the capital ever actually occurs, this topic allows for the analysis of the multiple and complex structures and interests implied, particularly those relevant to the relationship between the central and local governments. The project of transferring the capital has been raised again in view of the urban conditions of the capital, congestion and pollution, and the impact of the bubble period, which led to increased land prices and penalized numerous urban redevelopment projects, particularly those of the public sector. Writers have recurrently denounced Tokyo as a "black hole" (burakku horu) for its absorption of energy and capital and its concentration of decision-makers and decisions that are incommensurate with what the city gives back to the nation as a whole. Numerous publications explore the concept of Tokyo (Tôkyô mondai) as a problem (Pelletier 2001; Flüchter 2002; Uchinaka 1996; Ichikawa and Fujisôken-Tôkyômondai-kenkyû kai 1995; Ichikawa 1996; Takeda 1997) (Figure 8.1).

Kanemaru Shin, the powerful leader of the LDP, initiated the third wave of interest in capital relocation in the late 1980s. ${ }^{10}$ Some analysts saw this gesture as an attempt to launch a seemingly new project at a time when an old party was in trouble, touched by scandals and loss of members. It may be also considered an attempt to relaunch the Japanese economy through public works, as has been typical in Japan. In November 1990 the Diet voted to approve the relocation, with only the JCP and some outsiders, including Ishihara, the future Tokyo governor, weighing in against it. Political leaders of the LPD defended the idea and the Diet passed two laws related to the issue in December 1992 and June 1996. In 1999, the "Investigation Committee for the Relocation of the Diet and other Organizations" (Kokkaitô iten shingikai), created by the second law and presided over by Ishihara Nobuo (no relation to Shintarô), a former member of the prime minister's office, decided on the principle of a total transfer (yoto) of the capital to a new town more than 60 kilometers but less than two and a half hours by Shinkansen (bullet train) from Tokyo.

Three sites were proposed for the new capital: the Hokuto area on the border of the Tochigi prefecture (Kantô) and the Fukushima province (Tôhoku), northeast of Tokyo; a zone on the border of the Gifu and Aichi prefectures (Chûbu region), 



Figure 8.1 Sites under consideration for possible relocation of the national capital of Japan.

northeast of Nagoya; and the Mie-Kio area on the border of the Mie, Nara, and Shiga prefectures, on the condition that a high-speed transit network be built. All of these sites are located in central Honshû in close proximity to Greater Tokyo, Greater Nagoya, and Greater Osaka, reaffirming the importance of these centers in Japan. The problematic question of the need to move the imperial palace, and thus to question the role of the emperor in a Japanese democracy, had been excluded from the debate.

The idea of relocating the capital, which is at least as old as the idea of reorganizing local governments, cannot necessarily be considered part of a decen- 
tralization movement. The concept of decentralization is often associated with a political and administrative restructuring. Effectively, however, administrative reorganization may imply further centralization and the fusion of ministries, as initiated in 1996 by Prime Minister Hashimoto Ryûtarô. As the Hosokawa government emphasized the reform of the hierarchical relationship between the government and local governments, the decentralization of political and administrative functions took precedence over spatial and territorial redistribution issues. Considering decentralization as a purely political and administrative function has the advantage of casting the relocation of the capital as a simple deconcentration measure that may or may not be part of political administrative restructuring. The relocation of the capital, does not, per se, mean the creation of a new political and administrative system, although it can be part of it. A comparison with the cases of Ottawa, Canberra, or Brasilia, all cities whose construction was related to the establishment of a federal system of some kind, is not valid. It is unlikely that Japan will become a federal country. A future Japanese federation may need a new capital, but a new capital does not need a federation and, whereas plans for relocating the capital had taken precedence before 1996, the issue of political decentralization took precedence thereafter.

The Tokyo Metropolitan Government, under a series of governors (Suzuki Shun-ichi, Aoshima Yukio, and Ishihara) has argued against moving the capital, citing huge costs and possible negative impacts on the real-estate market in Tokyo and Japan as a whole.

The election of Ishihara reinforced the position of those who were against relocating the capital. The complexity of the problem, the rivalries between ministries, between government and Diet, between national and local governments, between the national government and the private sector, between private enterprises, and between different factions, strengthened the opposition strategy, but it did not solve the issue of relocation.

The defenders of the project organized as well. Provincial prefectures tried to unify. Meanwhile the private sector favored the project, as a symbol of changes in the administrative and government structure. ${ }^{11}$ Their aim seemed to be to keep the provincial bureaucrats out of Tokyo so that the city could pursue its growth as an economic and cultural center. In September 2000, the new Minister of Construction, Ogi Chikage, who was also head of the National Land Agency (Kokudochô), in charge of the capital relocation, proclaimed her opposition to the project. As part of a new government established in June 2000 (after the death of Prime Minister Obuchi Keizô), she was appointed in order to bypass the powerful concrete lobby after the downfall of her predecessor, Nakao Ei'ichi, following corruption charges. President of the New Conservative Party (Shin-Hoshutô), Ogi was considered the right person to reform the system. Other members of the government supported her, among them Sakaiya Taichi, a famous essayist, former official of the Ministry of International Trade and Industry (MITI), and minister in the Obuchi cabinet, who had opposed the relocation of the capital in the early 1990s. Given the dire financial situation, LDP leaders echoed similar sentiments, with Secretary of the Environment Kawaguchi Yoriko pointing out that the mon- 
ies could be better used elsewhere, for example, in the improvement of the sewage system. Beyond the financial argument, the abandonment of the capital-relocation project also opened the way for the desertion of all radical decentralization ideas. It was thus a victory for the conservative camp, for the Tokyo government, and for those aiming to create a new regional body (Tôgo 2001; Watabe 2002).

\section{The outlook for decentralization in twenty-first-century Japan under the pressure of globalization}

The abandonment of the capital relocation project in 2000 by the central government seems to indicate a partial rejection of a government policy that had proclaimed its desire for decentralization. Nonetheless, a new law passed in April 2004 allowed local governments to independently establish new taxes. Some of them have seized on the occasion to increase their revenues and include, for example, a fishing tax (Fujikawaguchikô-chô, Yamanashi-ken), an automobile parking-lot tax (Dazaifu-shi, Fukuoka-ken), and taxes on every consumer item from plastic bags to mineral water, as well as on one-room apartments. In many cases, however, local governments fear reprisals from voters and have refrained from levying any new taxes.

Simultaneously, the Koizumi government is actively working towards centralization, introducing legislation for consolidating towns and villages with the aim of reducing public expenses and rationalizing equipment. ${ }^{12}$ The communes involved, however, see it as a loss of autonomy and an indicator of their disappearance. Furthermore, the Koizumi government proposes a reduction of financial transfers to local authorities and the creation of regions (dôsh $\hat{u}$ ) formed from several prefectures that would disappear. Japan would thus have nine dôsh $\hat{u}$ plus Hokkaido, which, as the governmennt announced in 2003, would be the only prefecture that would not be transformed and that would serve as a model for the new organization. ${ }^{13}$ The reorganization of Japanese space would necessitate a constitutional reform that would have even greater impact than the privatization of the postal services. The reelection of the LPD and Koizumi in September 2005 seems to indicate that these projects will be realized.

The Japanese political, economic, and social systems are changing from within, as a result of a number of publicized instances of corruption, the rise of new citizens' and women's groups, deregulation, union restructuring, higher unemployment, and globalization. While Japan's major cities feed the economic development of the nation, they are also increasingly subject to globalization processes and their impacts. A series of contradictions characterize this development: the need to remain competitive on a global scale, while facing the pains of growth and gigantic development; the need to organize a rapidly growing urban body, in spite of the heritage of territorial models that hinder the existence of real metropolitan governance; and the necessity for governance on a metropolitan scale, which clashes with the desire of citizens to control what happens in their communities as socioeconomic differences increase. These contradictions are exaggerated in the capital city of Tokyo, caught between the central government, 
which it hosts, and its interests as a global city and metropolis that controls the rest of the country. With few exceptions, such as tourism and military bases, the forces of globalization are reinforcing centralization tendencies in Japan, leaving only developments of limited, local importance for decentralization.

\section{Notes}

1 Among those who have written on Japan as a top-down, hierarchical system are Chalmers Johnson, Kurt Steiner, Karel van Wolferen, and Gavan MacCormack.

2 At the end of the 1980s, Hara Takehiro, a former highly placed official in the Ministry of Construction, became director of the Builders' Federation, a group of 53 major public-works construction companies. See Pons (1988).

3 For a discussion of earlier protests that often went almost unnoticed, during the mid1980s, see Ikeya (1984).

4 Two forms of amakudari (which translates as "descending from heaven") can be distinguished: a transfer from the public to the private sector after retirement, to the boards or as consultants to administrations, banks, or industries; and a move from the administrative to the political, notably prefectural, sector.

5 At age 23, Ishihara won the prestigious Akutagawa literary prize for his novel Taiyô no kisetsu (1955; translated into English as Season of Violence in 1966). The story of a postwar Japanese youth who opposes every normative moral and traditional custom, this book inspired the name "sun tribe" (taiyôzoku) given to a generation of rebels without cause for whom Ishihara became a popular idol. Having finished his studies at Hitotsubashi University, Ishihara entered into politics in 1968 and held various important positions. In 1975, he ran for governor of Tokyo, but in spite of significant support, lost to Minobe Ryôkichi. Ishihara's attempts to obtain leadership positions within the LDP did not succeed, probably because he was perceived as an ultra-conservative.

6 Since 2000, he has eliminated 4,800 staff members (including police and school personnel). Some of his initiatives, such as a tax on banks with high assets, are still being addressed by the courts (see Nihon Keizai Shimbun February 8-9, 2000). This tax has already garnered large revenues. The banks have appealed; if the TMG loses, it will be required to reimburse the institutions with what some press sources claim might amount to 162.8 trillion yen (www.fpcj.jp/e/shiryo/jb/0314.html, accessed April 2004).

7 Among the most important measures have been the creation of new types of planned districts with higher land-use ratios, called "urban renewal plans" (saikaihatsu chiku keikaku), in 1988; the establishment of "planned districts with high land-use ratios for residential use" (yôtobetsu yôseki gata chiku keikaku), in 1997; and the creation of "districts favoring high-rise residential housing in urban centers" (kôsô jûkyo yûdô chiku), also in 1997.

8 The most prominent urban renewal projects include Media City Shiodome (31 hectares), Ôkawabata River City 21 (28.7 hectares), Harumi Triton Square (8.5 hectares), Toyosu (110 hectares), Shinonome (16.4 hectares), Rainbow Town (442 hectares), and Shibaura-Kônan.

9 On the contrasts in the geography of the electorate (voters and non-voters) in Tokyo, see Kôno (2001).

10 Even before the 1980s and the third wave of interest in moving the capital, Kanemaru Shin was the first president of the "Reflection group on the question of the new capital" (Shinshuto mondai zadankai), founded in 1975, which - typically - included political leaders from the majority and the opposition as well as representatives from universities and other intellectuals. As head of the Kokudochô (National Land Agency), Kanemaru revived the capital relocation project. 
11 Keidanren, February 6, 1996: "We propose relocation of Capital." It is not coincidental that the Keidanren, the Japan Federation of Economic Organizations, chose this date, which is associated with the myth of the foundation of the Japanese Empire, to highlight its position (see http://www.keidanren.or.jp/english/policy/pol040.html, accessed May 15, 2005).

12 Following on the Municipal code (shisei) and the Town and Village code (chôsonsei) enacted in 1888 the number of local entities dropped by about one-fifth from 71,314 to 15,859 . After a 1953 law another two-thirds disappeared, reducing the number from 9,868 to 3,472 . A law enacted in 1999 projected another reduction of two-thirds of the number of communes to 1,000. Between April 2004 and March 2005 more than 250 communes fused to form 60 entities. This process is particularly important in rural areas such as the departments of Ehime and Akita.

13 Hokkaidô, Tôhoku-shû (Aomori, Iwate, Miyagi, Akita, Yamanashi, Fukushima), Hokuriku-shû (Niigata, Toyama, Ishikawa), Kitakantô-shû (Gunma, Tochigi, Ibaraki), Shutoken-shû (Tôkyô, Kanagawa, Saitama, Chiba, Yamanashi), Chûbu-shû (Shizuoka, Nagano, Gifu, Aichi, Mie), Kansai-shû (Fukui, Shiga, Kyôto, Ôsaka, Nara, Wakayama, Hyôgo), Chûbu-shû (Okayama, Hiroshima, Yamaguchi, Tottori, Shimane), Shikokushû (Tokushima, Kagawa, Ehime, Kôchi), and Kyûshû (Fukuoka, Saga, Nagasaki, Kumamoto, Ôita, Miyazaki, Kagoshima, Okinawa).

\section{References}

Akizuki Kengo (1995) "Institutionalizing the local system: The Ministry of Home Affairs and intergovernmental relations in Japan," in Hyung-Ki Kim, Muramatsu Michio, Thomas J. Pempel, and Yamamura Kozo (eds.) The Japanese Civil Service and Economic Development, Oxford: Clarendon Press, pp. 337-66.

Asahi Shimbun-sha (ed.) (2004) Asahi kîwâdo (Asahi keywords), Tokyo: Asahi Shimbunsha.

Barrett, Brendan F. (2000) "Decentralization in Japan: Negotiating the Transfer of Authority", Japanese Studies 20(1): 33-48.

Evans, Neil (2002) "Machizukuri as a New Paradigm in Japanese Urban Planning: Reality or Myth?" Japan Forum 14(3): 443-64.

Flüchter, Winfried (2002) "Eine neue Haupstadt für Japan?" Geographische Rundschau 6(36-43): 36-43.

Fujita, Kuniko (2003) "Neo-industrial Tôkyô: Urban Development and Globalization in Japan's State-centred Developmental Capitalism," Urban Studies 40(2): 249-81.

Hein, Carola (2004) "Trauma und Stadtplanung. Der Wiederaufbau von Tokio und Hiroshima nach dem Zweiten Weltkrieg," in Bettina Fraisl and Monika Stromberger (eds.) Stadt und Trauma/City and Trauma. Annäherungen - Konzepte - Analysen, Würzburg: Königshausen \& Neumann, pp. 105-22.

Hill, Richard Child and Fujita, Kuniko (2000) "State Restructuring and Local Power in Japan," Urban Studies 37(4): 673-90.

Hohn, Uta (2002). "Ökonomischer und stadtstruktureller Wandel in der Global City Tôkyô," Zeitschrift für Wirtschaftsgeographie 46(3/4): 228-45.

Ichikawa Hiroo (1996) "Shuto kinô iten rongi to gendankai no kadai" (The debate on the moving of the capital functions and its current state), Toshi mondai 87(9): 15-30.

Ichikawa Hiroo and Fujisôken-Tôkyômondai-kenkyû kai (1995) Tôkyô wa kô kawaru, "Sento" "bunken" no kisô chishiki (The way Tokyo changes: Basic notions on "moving the capital" and "redistribution of the capital"), Tokyo: Tôyô keizai shinpôsha. 
Ikeya Kazunobu (1984) "Damu kensetsu ni yori suiyaku yotei ni aru shûraku no henbô" (Changes in a village where the building of a dam is decided), Tôhoku Chiri 36(2), 91-104.

Ishida Yorifusa (1998) "Hausse des coefficients d'occupation des sols et environnement urbain," Daruma 3: 101-33.

Ishihara Shintarô and Etô Jun (1991) Danko "no" to ieru Nihon (The Japan that can firmly say "no"), Tokyo: Kôbunsha.

Ishihara Shintarô and Morita Akio (1989) "No" to ieru Nihon (The Japan that can say "no"), Tokyo: Kôbunsha.

Ishimaru Norioki (2000) "On the Actual Conditions of Employment and Transference of City Planners in Japanese Local Government: A Case Study of City Planners in Hiroshima Prefecture and Hiroshima City during the Period of Reconstruction Planning in the War-Damaged Area," paper presented in the section "Urban and Environmental Studies" at the conference of the European Association for Japanese Studies, Lahti, Finland, 2000,

Jain, Purnendra (1999) “Japan's 1999 Unified Local Elections: Electing Tôkyô’s Governor," Japanese Studies 19(2): 117-32.

Kajita Shin (2001) "Public Investment as a Social Policy in Remote Rural Areas in Japan", Geographical Review of Japan 74(B)(2): 147-58.

Kôno Masaru (2001) "Tôkyô-to gikaigiin senkyo no tohyôritsu - Seido, kyôsôsei, minshushugi" (The level of participation in the departmental assembly elections of Tokyo-To - System, competition and democracy), Toshi mondai 92(10): 67-85.

MacCormack, Gavan (2002) "Breaking Japan's Iron Triangle," New Left Review 13: 523.

Mochida, Nobuyuki (1993) Toshi zaisei no kenkŷ̂ (Study of public finance of Japanese cities), Tokyo: University of Tokyo Press.

Muramatsu Michio (1997) Local Power in the Japanese State, Berkeley, CA: University of California Press.

Pelletier, Philippe (1998) "Glocal Tôkyô - Trois exemples d'évolution socio-spatiale à Tôkyô," Daruma 3: 69-81.

—-(2001) "La capitale du Japon, un déménagement difficile," L'information géographique 65: 97-124.

Pons, Philippe (1988) “Les grands travaux au Japon, un sanctuaire bien gardé," Le Monde March 15 1988: 10.

Saitô Asato (2003) "Global City Formation in a Capitalist Developmental State: Tôkyô and the Waterfront Sub-centre Project," Urban Studies 40(2): 283-308.

Scoccimarro, Rémi (1998) "Le soleil et l'acier," Daruma 3: 53-67.

Shigemori Akira (1998) "Chihô bunken to zei zaigen mondai" (The problem of tax revenues and financial resources in decentralization), in Chiho bunken no yugami (The strain of decentralization), Tokyo: Jichitai kenkyûsha, pp. 34-41.

Takeda Tôru (1997) "Pourquoi transférer la capitale?" Cahiers du Japon 73: 43-7.

Tôgo Hisatake (2001) "Tôkyô-to seiron saikô - Tôkyô kensei no sôritsu ni mukete" (Reconsidering the debate about the administrative system of Tôkyô prefecture Toward the creation of a Tôkyô region), Toshi mondai kenkyû 53(9): 54-66.

Toki Hiroshi (1992) "Tôkyô no seiji - Tosei to kokusei no taikô kankei" (The politics of Tokyo - The opposing relations between the central administration and that of Tokyo), in Tôkyô to Nyûyôku, daitoshi mondai he no chôsen (Confronting the metropolitan problems of Tôkyô and New York), Tokyo: Nihon Hyôron-sha, pp. 241-71.

Uchinaka Eisuke (1996) Shuto iten (Moving the capital), Tokyo: Asahi News Shop. 
Udagawa Akihito (1983) "Zaisei tôyûshi” (Fiscal investment and loan program), Kôdansha Encyclopedia of Japan, Tokyo: Kôdansha, 8: 367b.

Watabe Tatsurô (2002) "'Shutoken megaroporisu kôsô' to 'Shutoken kihon-keikaku'” ("The Capital megalopolis concept" and the "Comprehensive capital plan"), Toshi mondai 93(11): 37-50.

Woodall, Brian (1996) Japan under Construction: Corruption, Politics, and Public Works, Berkeley, CA; University of California Press.

Yoneyama, Lisa (1999) Hiroshima Traces: Time, Space, and the Dialectics of Memory, Berkeley, CA: University of California Press. 


\title{
Select glossary of terms
}

\author{
English-Japanese
}

Agency-delegated administration kikan inin jimu

Air Defense Law bôkû hô

Approval shônin

Architectural Institute of Japan Nihon Kenchiku Gakkai

Area demarcation kuiki kubun, senbiki

Areas with densely packed wooden houses mokuzô jûtaku misshû shigai chi

Bay ring road Tôkyô wan kanjô dôro

Betterment levy juekisha futankin

Blocking out of sunlight nichiei kisei (1976)

Building nuisances kenchiku kôgai

Building Standards Law (1950) kenchiku kijun hô

Built-up Area shigaika kuiki

Business Node gyômu kaku toshi

Cabinet Ordinance Designated Major Cities seirei shitei toshi

Capital Construction Law (1950) shuto kensetsu hô

Capital Region shutoken

Capital Region Development Law shutoken seibi hô

Central City Planning Council Toshi keikaku Chûô Shingikai

Central ring road kenô dô

Cities within Peripheral Zone shûhen toshi

City Planning Law (1919) see kyû toshi keikaku hô; (1968) see shin toshi keikaku hô

City Planning Research Committee toshi keikaku chôsa iinkai

Civil engineering state doboku kokka

Committee for the Promotion of Decentralization chihô bunken suishin

iinkai

Community chô, machi

Community-building machizukuri

Conceptual Draft Plan for Capital Region Development (1984) Tôkyô

daitoshi ken kinô tenkai zu

Convention of Eight Prefectures and Designated Cities kenshi kyôgikai

Council of Social Welfare (CSW) Shakai Fukushi Kyôgikai 
Decentralization chihô bunken

Densely packed wooden houses mokuzô jûtaku misshû shigai chi

Development Plan for Resident-Friendly Tokyo (1997) seikatsu toshi Tôkyô kôsô

Direct proposal chokusetsu seikŷ̂

District environment improvement project chiku kankyô seibi keikaku

District planning system (1980) chiku keikaku seido

Existing Urbanized Area kisei shigaichi

Expropriation chitai shûyô, chôka shûyô

Factory Regulation Law kôgyô tô seigen hô

Fifteen Years War jûgonen sensô

First Tokyo Capital Region Plan shutoken seibi dai ichiji kihon keikaku

Flexible operation jûnan na unyô

Floor-area Ratio Regulation System yosekiritsu seido

Fourth Comprehensive National Development Plan yônzensô

Government ordinance seirei

Guidelines on land development takuchi kaihatsu shidô yôkô

Guidelines on the construction of medium- to high-rise buildings chû kôsô

kenchiku shidô yôkô

Imperial decree chokurei

Independent foundation zaidan hôjin

Inner Urban Zone naibu shigai chitai

Investigation Committee for the Relocation of the Diet and other

Organizations Kokkaitô iten shingikai

Land readjustment kukaku seiri or kôchiseiri seido

Landscape disputes keikan ronsô

Land-use regulation zoning (1980) chiku keikaku seido

Land-use regulation zoning plan yôto chiiki seido

Law for the Promotion of Decentralization (1995) chihô bunken ikkatsu hô

Liberal Democratic party (LDP) Jimintô

Local allocation tax system chihô kôfuzei seido

Local autonomy chihô jichi

Local Autonomy Law (1947) chihô jichi hô

Local government jichitai

Local Government Amalgamation shi chô son gappei

Local taxes chihô zei

Machizukuri ordinance machizukuri jôrei

Metropolis daitoshi and daitoshi-ken

Military City Plan gunto toshi keikaku

Ministry of Construction Kensetsushô

Ministry of Finance Okurashô

Ministry of General Affairs Sômushô

Ministry of Internal Affairs and Communications Sômushô

Ministry of Local Affairs Jichishô

Ministry of the Interior Naimushô, Home Ministry 
Municipal code shisei

National Capital Construction Committee (NCCC) shuto kensetsu iinkai

National Capital Construction Law (1950) shutoken kensetsu hô

National Capital Development shutoken seibi

National Capital Region Development Plan (NCRD) shutoken seibi kihon

keikaku

National Land Agency Kokudochô

Neighborhood chô, machi, community

Neighborhood associations chônaikai

New City Planning Act or Law (1968) shin toshi keikaku hô

New industrial city shinsangyô toshi

New Industrial City Plan (1962) shinkô kôgyô-toshi keikaku

Non-profit organization (NPO) tokutei hieiri katsudô hôjin

Not yet specified zones mishitei chiku

Omnibus Law for Decentralization of Powers chihô bunken suishinhô

Option system sentaku-sei

Osaka Urban Area Improvement Law Ôsaka shigai kairyô hô sôan

Outline of the bill hôan yôkô

Participation kanyo

Peripheral Zone shûhen chiiki

Plan for the Reconstruction of the Capital shuto kaizô keikaku

Plan of Freeways in the Capital Region shuto kôsoku dôro keikaku

Policy to forcibly merge cities and municipalities shi chô son gappei sokushin

Rationalization gôrika

Reconstruction Plan for Tokyo (1946) Tôkyô sensai fukkô keikaku

Research core risâchi koa

Research park risâchi pâku

Residential Environment Improvement Program jûkankyô seibi jigyô

Site improvement along streets kenchiku shikichi zôsei kukakuseiri

Special City Construction Laws tokubetsu toshi kensetsu hô

Special City Planning Law tokubetsu toshi keikaku hô

Special Measures Law on Urban Regeneration toshi saisei kinkyû tokubetsu sochi hô

Specific-use buildings control area tokubetsu yôto seigen kuiki

State as builder doken kokka

Sub-center fuku toshin

Suburban Green Space Preservation Law (1968) kinkô ryokuchi hô

Suburban Zone kinkô chiiki

Suggestion system môshide seido

Sunlight Ordinance hiatari jôrei

Super Block Development System tokutei gaiku seido

Taxes on land value increases tochi zôka zei

Third Comprehensive National Development Plan sanzensô

Three-in-one reform sanmi ittai teki kaikaku

Tokyo Capital Government Tôkyô tochô 
Tokyo City Assembly Tôkyô-shi gikai

Tokyo City Building Ordinance (1906) Tôkyô-shi kenchiku jôrei

Tokyo Green Space Plan (1936) Tôkyô ryokuchi keikaku

Tokyo Metropolitan Government (TMG) Tôkyô-to

Tokyo Metropolitan Police Department keishi sôkan

Tokyo Metropolitan Zone Tôkyô dai toshi ken

Tokyo Prefectural Assembly Tôkyô fukai

Tokyo Urban Area Improvement Ordinance Tôkyô shiku kaisei jôrei

Tokyo Urban Area Improvement Project Tôkyô shiku kaisei jigyô

Town and Village code chôsonsei

Town-building machizukuri

Traditional wooden town house machiya

Unspecified zones mu shitei chiku

Urban Building Law shigaichi kenchiku butsu hô

Urban Regeneration Areas of Urgent Needs toshi saisei kinkyû seibi chiiki

Urban Regeneration Law (2002) toshi saisei hô

Urbanization Promotion Zone shigaika kuiki

Voluntary covenants kenchiku kyôtei

War Damage Restoration Plan sensai fukkô toshi keikaku

Zone expropriation chitai shûyô, chôka shûyô

\section{Japanese-English}

Ainori literally "jumping aboard," a way of sharing power beyond party lines Amakudari literally "descending from heaven," a transfer from the public to the private or political sector after retirement

Bôkû hô Air Defense Law

Chaya tea house

Chihô province(s)

Chihô bunken decentralization

Chihô bunken ikkatsu hô (1995) Law for the Promotion of Decentralization, Omnibus Law for Decentralization of Powers

Chihô bunken suishin iinkai Committee for the Promotion of Decentralization

Chihô jichi hô (1947) Local Autonomy Law

Chihô jichitai local government

Chihô kôfuzei seido local allocation tax system

Chihô zei local taxes

Chihôsai local bonds

Chiku kankyô seibi keikaku district environment improvement project

Chiku keikaku seido (1980) district planning system

Chitai shûyô zone expropriation

Chô or machi neighborhood, community

Chôgumi groups of chô

Chôka shûyô zone expropriation

Chokurei imperial decree 


\section{Glossary}

Chokusetsu seikŷu direct proposal

Chônai neighborhood

Chônaikai neighborhood organization

Chônin townsman, townspeople

Chôshikimoku or chôsadame detailed written rules in Kyoto's chô

Chôsonsei Town and Village code

Chî kôsô kenchiku shidô yôkô guidelines on the construction of medium- to high-rise buildings

Chûkaku shi big city, see also seirei shitei toshi

Daitoshi metropolis

Daitoshi-ken metropolitan area

Dango official bid

Doboku kokka civil engineering state

Dôi agreement

Doken kokka state as builder

Dôro keikai rei Ordinance for Road Boundaries

Eisei kyoku Sanitation Bureau

Fuku toshin sub-center

Furusato literally "my home town"

Geko railway lines that "go down from the capital (to a province)"

Gijutsu kijun technical standards

Goningumi five-family groups

Gyômu kaku toshi Business Node

Gyôsei shidô administrative guidance

Hiatari jôrei Sunlight Ordinance

Jichi rengôkai neighborhood association

Jichishô Ministry of Local Autonomy

Jichitai local government

Jimintô Liberal Democratic Party (LDP)

Jôkyô railway lines that "go up to the capital"

Juekisha futankin betterment levy

Jûgonen sensô Fifteen Years War

Jûkankyô Seibi Jigyô Residential Environment Improvement Program (1978)

Kakushin jichitai progressive or innovative local governments

Kanchi zei taxes on land value

Keikan chiku townscape district

Keikan hô Townscape Law

Keikan ronsô landscape disputes

Keishi sôkan Tokyo Metropolitan Police Department

Kenchiku kijun hô Building Standards Law

Kenchiku kyôtei voluntary covenants

Kenô dô central ring road

Kensetsushô Ministry of Construction

Kenshi kyôgikai Convention of Eight Prefectures and Designated Cities

Kikan inin jimu agency-delegated administration 
Kinkô chiiki Suburban Zone

Kinkô ryokuchi hô Suburban Green Space Preservation Law

Kisei shigaichi Existing Urbanized Area

Kôchiseiri seido land-readjustment system

Kôgyô tô seigen hô Factory Regulation Law

Kokkaitô iten shingikai Investigation Committee for the Relocation of the Diet and other Organizations

Konbinâto industrial complex

Kubukai Sectional Meeting by Members from wards

Kuiki kubun area demarcation

Kukaku seiri land-readjustment

Kŷ̂ toshi keikaku hô, or 1919 nen toshi keikaku hô Old City Planning Act or Law (1919)

Machi or chôi neighborhood, community

Machi kaisho council of townsmen

Machiya traditional wooden town house

Machizukuri community-building, town-building

Minkatsu promotion of the participation of private enterprise

Mishitei chiku not yet specified zones

Mokuzô jûtaku missh $\hat{u}$ shigai areas with densely packed wooden houses

Mokuzôkai Wooden Building Association

Mu shitei chiku unspecified zones

Naibu shigai chitai Inner Urban Zone

Naimu daijin Minister of the Interior/Home Minister

Naimushô Ministry of Interior/Home Ministry

Nihon Kenchiku Gakkai Architectural Institute of Japan

Nihon Toshi keikaku Gakkai City Planning Institute of Japan

Ninka authorization

Okushon a play on the terms manshon and oku, the result of a public and private move to attract a wealthier population to the center

Ôsaka shigai kairyô hô sôan Osaka Urban Area Improvement Law

Pâtonashippu partnership

Purehabu prefabricated single-family houses

Rigai kankeinin interested individuals

Rinji doboku chôsa iinkai (1899) temporary committee for the purpose of producing a survey of public works

Rinkai fuku toshin Seaside Center

Risâchi koa research core

Risâchi pâku research park

Risutora company downsizing (restructuring)

Ryôgawa-chô "two-sided block," block (chô) that includes the houses on both sides of a street from one corner to the next

Ryokuchi chiiki green space zoning

Sandai jigyô "Big Three" projects

Sanzensô Third Comprehensive National Development Plan 
Seirei shitei toshi Cabinet Ordinance Designated Major Cities

Sekai toshi global city

Senbiki area demarcation

Sentaku-sei option system

Shakai Fukushi Kyôgikai Council of Social Welfare (CSW)

Shi chô son gappei sokushin policy to forcibly merge cities and municipalities

Shi chô son gikai municipal assembly

Shi chô son toshi keikaku shingikai Municipal City Planning Council

Shibiru minimamu "civil minimum" minimum government services considered necessary for a satisfactory urban life

Shichibu tsumi kin 7 percent deposit for the poor

Shigaichi kaihatsu kuiki New Urban Development Area

Shigaichi kenchiku butsu hô Urban Building Law

Shigaichi seibi improvement of urban area

Shigaika chôsei kuiki Urbanization Control Zone

Shigaika kuiki Urbanization Promotion Zone, Built-up Area

Shiku kaisei jigyô Urban Improvement Project

Shimin undô citizen group

Shimin-ban citizen-made

Shimogyô lower city

Shin toshi keikaku hô (1968) New City Planning Law or Act

Shingikai council

Shinkô kôgyô-toshi keikaku (1962) shinsangyô toshi or New Industrial City

Plan

Shinsangyô toshi new industrial city

Shisei Municipal code

Shônin approval

Shûgiin giin House of Representatives

Shûhen chiiki Peripheral Zone

Shûhen toshi city in the Peripheral Zone

Shukk $\hat{\boldsymbol{o}}$ temporary imput

Shuto (National) Capital

Shuto kaizô keikaku (1985) Plan for the Reconstruction of the Capital

Shuto kensetsu hô (1950) National Capital Construction Law

Shuto kensetsu iinkai National Capital Construction Committee

Shutoken National Capital Region

Shutoken seibi National Capital Development

Shutoken seibi dai ichiji kihon keikaku first Tokyo Capital Region Plan

Shutoken seibi hô National Capital Region Development Law

Shutoken seibi kihon keikaku National Capital Region Development Plan

Shutoken seibi kôsô keikaku soan Conceptual Plan for Capital Region

Development

Sômushô Ministry of Internal Affairs and Communications

Takuchi kaihatsu shidô yôkô guidelines on residential land development

Takyoku bunsan multi-polarized structure 
Tochi zôka zei taxes on land value increases

Tokubetsu toshi keikaku hô Special City Planning Law

Tokubetsu toshi kensetsu hô Special City Construction Law

Tokubetsu yôto chiku special land-use districts

Tokubetsu yôto seigen kuiki specific-use buildings control area

Tokutei gaiku seido Super Block Development System

Tokutei hieiri katsudô hôjin non-profit organization (NPO)

Tôkyô dai toshi ken Tokyo Metropolitan Zone

Tôkyô ryokuchi keikaku (1936) Tokyo Green Space Plan

Tôkyô sensai fukkô Reconstruction Plan for Tokyo after World War II

Tôkyô shiku kaisei jôrei Tokyo Urban Area Improvement Ordinance

Tôkyô wan kanjô dôro Tokyo Bay ring road

Tôkyô-fukai Tokyo Prefectural Assembly

Tôkyô-kubu Tokyo borough area

Tôkyô-shi (1888-1943) City of Tokyo

Tôkyô-shi gikai Tokyo City Assembly

Tôkŷ́-to Tokyo Metropolitan Government (TMG)

Tôkyô-to chôki sôgô keikaku (1982) Long-Term Plan for the Tokyo Metropolis

Tôkŷ́-to gikai Tokyo Metropolitan Assembly

Toshi keikaku hô City Planning Law; see also kyû toshi keikaku hô (1919), shin toshi keikaku hô (1968)

Toshi saisei hô (2002) Urban Regeneration Law

Toshi saisei kinkyû tokubetsu sochi hô Special Measures Law on Urban

Regeneration

Yonzensô Fourth Comprehensive National Development Plan

Yôsekiritsu seido Floor-area Ratio Regulation System

Zaidan hôjin independent foundation

Zeigen ijô transfer tax revenue source

Zenkoku sôgô kaihatsu keikaku Comprehensive National Plan 


\section{Index}

Abu-Lughod, Janet 122

agency-delegated administration 44, 104

Agenda 21102

Aichi 34, 86, 174, 179

ainori 171,172

Air Defense Law 56

Akihabara 26

Akishima 55

Akizuki Kengo 164

Allinson, Gary 106

amakudari 168, 171, 178

America see United States of America anti-pollution movement 109, 118

Aomori 35, 179

Aoshima Yukio 72, 172, 176

Aoyama 79, 87

Architectural Institute of Japan 28

area demarcation 45; see also senbiki

Ariake Bay 170

Arisawa Hiromi 9

Arnstein, Sherry 135

Ashiya 37

Asukata Ichio 131

Atsugi 60, 76

autonomy $1-4,7,36,61,78,95,97,102$, $103,109,113,128,140,154,166,177$; see also local autonomy

Barret, Brendan 166

Barshay, Andrew 117

Basic Land Law (1989) 109

Bay ring road 68

Beard, Charles A. 31, 50

Bebauungsplan 41

Ben-Ari, Eyal 119

Beppu 37

Berry, Mary Elizabeth 141, 142

betterment levy 30, 31

blocking out of sunlight 39

bôkû hô see Air Defense Law
Borja, Jordi 102

bottom-up 46, 102, 103, 110

Broadbent, Jeffrey 119

Brumann, Christoph 7, 121, 139, 140, 142, $148,164,165$

bubble economy $11,13,20,74,76,81$, $82,87,89,90,101,109,139,140,167$. $169,171,174$

Building Control Regulations 28

building nuisances 39

Building Standards Law (1950) 37, 39-41, 44, 48, 64, 156

Built-up Area 40, 61, 67

burakku horu 174; see also Tôkyô mondai

Burnham, Daniel H. 134

Business Node 68, 71, 72, 74-6

Cabinet Ordinance Designated Major Cities 18, 19, 49, 57, 171

capital city $1-5,8,11,17,18,20,22-4$, $26,27,29,38,47,48,55,58,60-5,67$, $68,70-2,75-9,139,165,169,171$, 174-9; see also national capital

Capital Construction Law (1950) 38, 61, 62

capital functions $2,67,174$

Capital Region 55, 61-5, 67, 68, 70-2, 75-9; see also shutoken

Capital Region Development Law 61, 62, 78; see also shutoken seibi hô

capitalism 9

Castells, Manuel 102

Central City Planning Council 44

central ring road 68

centralization $2,3,7,14,25,37,48,49$, $65,102,103,105,109,166,169,176$, 177,178

chaya 148

Chiba 17, 19, 20, 57, 59, 60, 62, 65, 67, $68,71,74,76,78,171,179$ 
chihô 4, 5, 11, 19, 25, 34, 36, 44, 47, 56, 91, 95, 101, 160, 164, 166; see also province

chihô bunken see decentralization chihô bunken ikkatsu hô see Law for the Promotion of Decentralization (1995) chihô bunken suishin iinkai see Committee for the Promotion of Decentralization chihô jichi hô see Local Autonomy Law (1947)

chihô jichitai 5; see also local government chihô kôfuzei seido see local allocation tax system

chihô zei 5; see local taxes

chihôsai see local bonds

chiku kankyô seibi keikaku see district environment improvement project

chiku keikaku seido (1980) see district planning system

China 3, 9, 114, 115, 172, 173

Chirac, Jacques 147

chitai shûyô see zone expropriation chô $3,5,26,41,43,45,47,50,57,69$, $70-2,75,76,98,104,122,133,140-5$, 148, 156-8, 177; see also community, neighborhood

chôgumi 142, 143

chôka shûyô see zone expropriation chokurei see imperial decree chokusetsu seikyû see direct proposal chônai 143-5

chônaikai see neighborhood associations chônin 49, 141

chôsadame see chôshikimoku

chôshikimoku 142, 145

chôsonsei see Town and Village code chû kôsô kenchiku shidô yôkô see guidelines on the construction of medium- to high-rise buildings

chûkaku shi see Cabinet Ordinance Designated Major Cities

Chûô-ku 44, 173

citizen participation $7,25,37,39,41,46$, $103,131,133,135,137,146,149$

citizenry $1,39,129,154,164,172$

City of Tokyo (1888-1943) 3, 27

City Planning Act or Law (1919), 2-4, 27 , 29-34, 36, 37, 49, 56, 66, 105

City Planning Institute of Japan 29

City Planning Law 2, 25, 27, 29, 30-4, 36, 37, 39, 40-7, 49, 50, 56, 64, 67, 105, 107, 109; see also City Planning Act or Law (1919), New City Planning Act or Law (1968)
City Planning Research Committee 31-3

civil engineering 28, 29, 104, 167, 168

civil engineering state 167

civil minimum 40,50

civil society $7,101-3,110,114,116,117$, $120-3,153$

Cold War 8, 37, 117

Committee for the Promotion of Decentralization 91, 92, 95, 166; see also chihô bunken suishin iinkai

community 122, 133, 140, 141, 143, 148; see also chô, neighborhood

community-building 7, 18, 101, 121, 123, 128-7, 150, 160; see also machizukuri, town-building

Comprehensive National Plan 71

Conceptual Draft Plan for Capital Region Development (1984) 71

conceptual plan for the development of the Capital Region (1955) 63

Constitution 42

Convention of Eight Prefectures and Designated Cities 78

Council of Social Welfare (CSW) 129

daitoshi 4, 5, 71; see also metropolis

daitoshi-ken 4, 20; see also metropolitan area

dango 168

decentralization $1-5,7,8,10,11,18,19$, 25-7, 30, 32-5, 37-9, 41, 42, 44-50, $58,64,78,81,82,87,88,91,92,94-8$, $101,109,110,123,128,164-7,169$, $171,176-8$

decision-making process $37,40,41,45$, 137

deconcentration $4,5,14,55,57,58,65$, 67, 68, 70, 72, 74, 78, 165, 172, 176

Democratic Party 8, 41, 90, 101, 146, 151, 166

demographic evolution 17

Densely Inhabited District (DID) 19

deregulation $20,79,151,156,160,166-8$, 173,177

Development Plan for Resident-Friendly Tokyo (1997) 72

Diet 37, 41, 44, 45, 82, 86, 160, 172, 174, 176

direct proposal 39

district environment improvement project 40

district planning system 41

doboku kokka see civil engineering state dôi 44 
doken kokka; see state as builder dôro keikai rei 26

Edo 2, 18, 26, 49, 55, 111, 142; see also Tokyo

eisei kyoku; see Sanitation Bureau emperor 103; see also imperial decree environmental policy 101

Etô Jun 172

Existing Urbanized Area 62-5, 67, 71, 72, 75,76

expropriation see zone expropriation

Factory Regulation Law 64

Federal Republic of Germany 14, 19, 25, $33,156,165$

Fifteen Years War 3, 33

Fighting Maruyama 130, 131

finance 95

financial autonomy 92, 96, 98

financial transfer 82

First Tokyo Capital Region Plan 60

fixed-assets tax 82

flexible operation 46

Floor-area Ratio Regulation System 64

Fourth Comprehensive National

Development Plan 11, 71

France 13, 28, 84, 147, 152

Fuchû 55

Fujihara Toshio 32

Fujita, Kuniko 7, 11, 20, 167, 171

fuku toshin; see sub-center

Fukuoka 14, 18, 19, 38, 58, 171, 179

Fukushima 174, 179

furusato 111, 139

Garon, Sheldon 115

gekô 4

gentrification 17, 155

Germany see Federal Republic of Germany

Gifu 174, 179

gijutsu kijun 46

Ginza 26, 72

Gion matsuri 143, 145

global grant $82-5,96-8$

globalization 1, 2, 8, 11, 18, 102, 167, 177, 178

Gluck, Carol 103, 111, 113, 115

goningumi 112,113

Gotô Shinpei 31, 43, 50

government ordinance 42

Greater London Plan 61, 63

green belt $56,57,59,61-5$ green space $18,47,61,64,65,129,170$

Greenpeace 120, 123

guidelines on land development 38, 42; see also takuchi kaihatsu shidô yôkô

guidelines on the construction of mediumto high-rise buildings 42

Gunma 20, 55, 59, 60, 62, 65, 67, 179

gyômu kaku toshi; see Business Node

Hachiôji 60, 68, 72, 76

Hakodate 26

Hamamatsu 12, 13

Hashimoto Ryûtarô 89, 168, 169, 176

Hastings, Sally Anne 113-6

Hatoyama Yukio 166

Hein, Carola 1, 2, 4, 9, 19, 40, 101, 102, $150,164,166,173$

hiatari jôrei see Sunlight Ordinance

Higashi-Murayama 55

Hill, Richard Child 5, 7, 17, 167

Hiramatsu Morihiko 12

Hiratsuka 60

Hiro 35

Hiroshima 9, 19, 28, 58, 171, 179

Hokkaido 26, 177

Home Ministry 26, 27, 30, 31, 33, 34, 57, $104-6,115,116$

Hosokawa Morihiro 13, 166, 167, 176

House of Representatives 32

Howard, Ebenezer 134

Hyogo 26, 179

Ibaraki 20, 60, 59, 62, 65, 67, 68, 71, 74, 76,179

Igarashi Takayoshi 41, 42

Ikebukuro 72

imperial decree 31

income tax 96

independent foundation 149

infrastucture $2,7,12,13,45,67,75,81$, $87,89,90,95,105,107,108,111,132$, $149,167,168,170,171,174$

Inner Urban Zone 61

International Conference on City Planning, Amsterdam (1924) 56, 64, 78

Investigation Committee for the Relocation of the Diet and other Organizations 174

Isahaya 170

Ishida Yorifusa 1, 2, 4, 9, 19, 25, 26, 31, $33-8,40,42-4,46-50,56,59,61,63-$ $5,91,102,105-7,129,164,165,173$

Ishihara Shintarô 77, 78, 94, 172-4, 176, 178

Ishikawa Hideaki 3, 19, 34, 58, 60 
Japan Communist Party (JCP) 117, 146, $148,166,174$

Japan National Railways (JNR) 169

Japanese government 1-5, 7-10, 12, 13, 18-20, 25-30, 32, 34-42, 44, 45, 47, $48,57,58,60,61,78,82,83,85$, 88-98, 101, 103-9, 113, 115, 116, 119, $122,123,128,131,149,155,164-71$, $173,176,177$

jichi rengôkai 143, 144, 148, 153; see also neighborhood associations

Jichishô see Ministry of Local Affairs jichitai see local government

Jimintô see Liberal Democratic Party (LDP)

Jinno Naohiko 96

Jino Katsunosuke 31

jôkyô 4

juekisha futankin 30; see betterment levy

jûgonen sensô see Fifteen Years War

Jûkankyô Seibi Jigyô see Residential Environment Improvement Program

Kagoshima 19, 179

Kaizôron 12, 20, 169

Kajita Shin 167, 168, 170

kakushin jichitai 38

Kameido-Kinshichô 72

Kamigyô 142

Kamogawa 147, 152, 160

Kan Naoto 166

Kanagawa 17, 18, 19, 20, 26, 38, 42, 48, $55,59,60,62,65,67,68,71,74,76$, $78,79,86,87,93,97,173,179$

Kanbe Committee (1949-50) 5, 19, 36, 37, 39; see also Shoup Mission

kanchi zei see taxes on land value increases

Kanda 26

Kaneiwa Den-ichi 3, 34

Kansai 132

Kanto 3, 33, 34, 50, 55, 56, 58-60, 62, 65, $67,75,77,78,132,174$

Kanto National Land Plan 56

Kashiwa 60, 76

Kasukabe 60, 76

Kasumigaseki 64, 72

Kasumigaseki Building 64

Katayama Tetsu 117

Kawagoe 60, 76

Kawaguchi Yoriko 176

Kawasaki 10, 18, 55, 57, 65, 68, 74, 76, 78,171

Keihin 56 keikan chiku 160

keikan hô 160

keikan ronsô 140, 147, 148; see also landscape disputes

keishi sôkan see Tokyo Metropolitan Police Department

kenchiku kijun hô see Building Standards Law

kenchiku kôgai see building nuisances

kenchiku kyôtei 155, 157; see also voluntary covenants

kenô dô see central ring road

Kensetsushô 29, 39, 57; see also Ministry of Construction

kenshi kyôgikai see Convention of Eight Prefectures and Designated Cities

Keynesian activism 168; see also doken kokka

Kibi-Kôgen 12

Kichijôji 72

kikan inin jimu see agency-delegated administration

kinkô chiiki see Suburban Zone

kinkô ryokuchi hô see Suburban Green Space Preservation Law

Kisarazu 76

kisei shigaichi see Existing Urbanized Area

Kitakyûshû 18, 171

Kobe 14, 18, 26, 28-30, 33, 34, 49, 58, $130,131,133,135,149,150$

kôchiseiri seido 30; see also land readjustment

Kôfu 13, 20, 60

kôgyô tô seigen hô see Factory Regulation Law

Koizumi Jun'ichirô 91, 109, 168, 170, 173, 177

Kokkaitô iten shingikai see Investigation Committee for the Relocation of the Diet and other Organizations

Kokubunji 48

Kokudochô see National Land Agency

Komae 134

konbinâto 12

Korea 3

Kôriyama 12-14

Koromo 35

Koshigaya 76

Krauss, Ellis 108, 118, 146

kubukai 49

kuiki kubun see area demarcation kukaku seiri 3, 10, 28, 30, 34-6, 38, 49, 50, 55, 61, 129, 130; see also land readjustment 
Kumagai 76

Kumamoto 11-14, 19, 166, 179

Kure 28

Kyoto 4, 7, 18, 26, 28, 29, 33, 38, 57, 119, 139, 140-3, 146-152, 154-161, 171, 179

kyû toshi keikaku hô see City Planning Act or Law (1919)

Kyushu 10, 12, 19, 166, 170, 179

land price 17, 18, 74, 109, 139, 140, 155 , $156,159,174$

land readjustment $3,28,30,34-6,38,49$, 50, 55, 61, 129, 130; see also kôchiseiri seido, kukaku seiri

landscape disputes 140; see also keikan ronsô

land-use control 42, 46, 48, 49, 64

land-use planning 49,90

land-use regulation zoning 58

land-use rights 49

Law for the Promotion of Decentralization (1995) 1, 25, 166

Lee Teng-hui 173

Liberal Democratic Party (LDP) 8, 9, 13, 19, 41, 90, 91, 95, 101, 107, 109, 119, $146,151,152,166,168,169,172,174$, 176,178

local allocation tax system 48

local autonomy 2, 5, 7, 44, 81, 82, 96, 97, $104,106,134,139,140,150,152,153$, 156,161

Local Autonomy Law (1947) 36, 160

local bonds 5

local debt 83, 84, 97, 167

local democracy 170

local governance 101, 102

local government 1, 5, 7, 9-11, 13, 14, 19, 25-8, 30-3, 37-9, 41-50, 57, 64, 65, $67,72,78,79,81,86-93,95-7,101$, $102,104-9,113,114,116,118,120$, $122,123,131,149,151,153-5,164$, $166-8,171-7$

Local Government Amalgamation 47

local taxes 5, 7, 30, 82, 84, 85, 92, 94, 96

London 17, 21, 63

Long-Term Plan for the Tokyo Metropolis (1982) 72

MacCormack, Gavan 109, 167, 169, 178

machi kaisho 26, 49

Machida 40, 60, 72, 76, 79

machiya 140, 146, 147, 149-151,
154-6, 160; see also wooden houses, traditional

machizukuri 7, 18, 128-30, 133, 136, 137, 150; see also community-building, town-building

machizukuri ordinance 133

McKean, Margaret 118, 119

Maebashi 60

Manazuru 42

Manchuria 9

Mano 131, 132, 150

Marunouchi 72

Maruyama 130-2

Marxist 8, 9, 19

master plan 28, 35, 43, 60, 77, 78, 109, $133-5,137$

Masuda Shiro 128

Masumoto Yorikane 147

megalopolis 77

Meguro-ku 40

Meiji 2, 3, 9, 25-7, 48, 55, 103, 104, 114, 143,168

metropolis 49, 50, 71-4, 77; see also daitoshi

metropolitan area 68,71 ; see also daitoshiken

Mie 94, 175, 179

Military City Plan 35

Minato-ku 173

Ministry of Autonomy 5, 10

Ministry of Construction 10, 29, 37, 39, 42-5, 167-9; see also Kensetsushô

Ministry of Finance 92, 97, 98, 106, 169

Ministry of General Affairs 84-6, 91, 92, 95, 97; see also Ministry of Internal Affairs and Communications

Ministry of Internal Affairs and Communications 47, 83-6

Ministry of International Trade and Industry (MITI) 11, 12, 13, 20, 176

Ministry of Local Affairs 57, 83, 86, 92 , 164; see also Jichishô

Ministry of the Interior 3, 9; see also Naimushô, Home Ministry

Ministry of Welfare 129

minkatsu 12

Minobe Ryôkichi 40, 50, 131, 178

Mishima 130

mishitei chiku see not yet specified zones

Mito 60, 67

Miyabiyama-chô 143-5, 156-8

Miyake Iwao 32

Miyazaki Hayao 111

Miyazaki Tatsuo 131 
Miyazawa Kei-ichi 89

mokuzô jûtaku misshû shigai see wooden houses, densely packed

Mokuzôkai 146, 147, 150, 151, 154, 156-8

Mori Ôgai 33

Morita Akio 172

Morris-Suzuki, Tessa 20

môshide seido, see suggestion system

mu shitei chiku see unspecified zones

multipolar structure 69, 71-3

municipal code 3, 179

Muramatsu Michio 104, 164

Musashino 55

Nagano 170, 179

Nagaoka 20

Nagasaki 9, 35, 179

Nagoya 3, 4, 14, 17, 18, 20, 29, 33, 34, 57 , $71,129,171,175$

naibu shigai chitai see Inner Urban Zone

Naimu daijin 27

Naimushô 3, 9, 26, 31, 57, 104; see also Ministry of the Interior

Nakabayashi Itsuki 4, 35, 38-40, 55, 56, $62-4,66,165$

Nakane Chie 110-12

Nakao Ei-ichi 176

Nakasone Yasuhiro 8, 19, 87, 108, 169

Nara 133, 139, 175, 179

Narita 76

national capital see capital city

National Capital Construction Committee (NCCC) 61, 62

National Capital Construction Law (1950) 61,62

National Capital Development 65, 68; see also shutoken seibi

National Capital Region Development (NCRD) Plan 61-79; see also shutoken seibi kihon keikaku

National Land Agency 1, 71, 176, 178

national minimum 33, 97

National Science and Technology Agency 11

NEC 10, 19

neighborhood 122, 140, 141, 143, 148, 161 ; see also chô, community

neighborhood associations $7,110,113$, 114, 116-22, 140, 143, 144, 146, 147, $150,153,154,165$

Netherlands 30

New City Development 65, 67, 68

New City Planning Act or Law (1968) 1, 39, 40, 44, 67, 105, 107, 108, 133; see also City Planning Act or Law (1919),

City Planning Law

new industrial cities (1962) 12

New Industrial City Plan (1930s) 35

New Town 20, 67

New Urban Development Area 63, 65

Nihon Kenchiku Gakkai see Architectural Institute of Japan

Nihon Toshi keikaku Gakkai see City

Planning Institute of Japan

Nihonbashi 72

ninka 44

Ninomiya Sontoku 111

Noda 60, 140

non-profit organization (NPO) 120, 121, $133,136,147,149$

NTT 12

Numazu 60

Obuchi Keizô 176

Odawara 60

Ogi Chikage 176

oil crisis $11-13,68,81$

Ôita $12,19,179$

Okinawa 179

Okusei Shingi see Mori Ôgai

okushon 17,20

Ômiya 68,76

Omnibus Law for Decentralization of Powers see Law for the Promotion of Decentralization (1995)

option system 46

Organization for Economic Cooperation and Development (OECD) 89, 168

Osaka 4, 10, 14, 17, 18, 20, 26, 28-34, 38, $49,57,71,86,87,93,94,132,161$, $171,172,175$

Ôsaka shigai kairyô hô sôan see Osaka Urban Area Improvement Law

Osaka Urban Area Improvement Law 29

Ôsaki 72

Ôta 55

Ôtemachi 72

Ozawa Ichirô 167

Paris 7, 147

participation $7,12,20,27,28,39,40,41$, 44-6, 48, 61, 77, 101, 112, 130-7, 144, $145,152,166,170$

pâtonashippu 7, 149, 151, 152, 161

Pekkanen, Robert 120, 121

Pelletier, Philippe 1, 2, 19, 40, 101, 102, $164,166,169,172,174$

Peripheral Zone 61, 62, 65, 68, 71, 75, 78 
Peripheral Zone, cities within 61

periphery $1,2,4,5,68,164$

Plan for the Reconstruction of the Capital 11

Plan of Freeways in the Capital Region 61

Plaza Agreement (1985) 14, 88

polarization 68

policy to forcibly merge cities and municipalities see Local Government Amalgamation

pollution $18,38,107,108,118,119,122$, $130,131,170,174$

Pont des Arts 7, 147, 148, 149, 152-4, $156-8$

Postal Ministry 92

prefecture 5

privatization $12,87,88,167,168,170,177$

province 4, 5, 10, 11, 35, 167, 174; see also chihô

public finance $84,85,88,91,97,98$

public investment $13,167,168$

public sector 7, 81-4, 86-90, 93, 98, 99, $136,167,168,171,174$

public services $7,88,89,92,95-8,113$, $114,122,131$

public works $8,29,81,83,88-91,94,97$, $110,167,168,174$

purehabu 139

Pyle, Robert 115

Rainbow Town 173, 178

rapid growth $1,9,11,12,20,107,114$, 117,165

rationalization 45

reconcentration 1

Reconstruction Plan for Tokyo (1946) 59

referendum $98,148,154$

regulation $28,46,60,65,67,88,105,107$, 137

relocation $1,3,8,11,12,14,20,35,47$, $56,63,72,174-9$

research core 12

research park 13

resident tax 82, 92, 96

Residential Environment Improvement

Program 132

rigai kankeinin 45

right to sunlight 38,40

rinji doboku chôsa iinkai (1899) 29

rinkai fuku toshin 72, 172, 173

risâchi koa see research core

risâchi pâku see research park

risutora 148

Roppongi Hills Projects 79 ryôgawa-chô 141

ryokuchi chiiki 61; see also green space

Sagamihara 35, 55, 76, 79

Saitama 17, 19, 20, 38, 57, 59, 60, 62, 65, $67,68,71,74,76,78,179$

Sakae-Higashi 129, 131, 132

Sakaiya Taichi 176

Samuels, Richard 104, 107, 108

San Francisco Peace Treaty 37

sandai jigyô 29

Sanitation Bureau 26

sanzensô see Third Comprehensive

National Development Plan

Sapporo 18, 19, 26, 57, 171

satellite city or town $56,59,62-5,68,71$

Schebath, Alain 5, 7, 81, 82, 99, 106, 109, $164,165,167$

seirei shitei toshi see Cabinet Ordinance

Designated Major Cities

sekai toshi 17

Seki Hajime 29-32, 49

self-governance 7, 27, 38, 110-3

self-organization $113,143,154$

senbiki 45, 46; see also area demarcation

Sendai 14, 19, 57, 171

sentaku-sei see option system

Setagaya 133, 134, 150

Seto Bridge 169

Seto Inland Sea 170

Shakai Fukushi Kyôgikai see Council of Social Welfare

shi chô son gappei sokushin see Local

Government Amalgamation

shi chô son gikai 41

shi chô son toshi keikaku shingikai 45

shibiru minimamu 40

Shibuya 72

shichibu tsumi kin 26

Shiga 166, 175, 179

shigaichi kaihatsu kuiki see New Urban

Development Area

shigaichi kenchiku butsu hô see Urban

Building Law

shigaichi seibi 28

shigaika chôsei kuiki 67

shigaika kuiki see Built-up Area,

Urbanization Promotion Zone

Shigemori Akira 166

Shikoku 170, 179

shiku kaisei jigyô 26, 28

Shimane 179

shimin undô 146

shimin-ban 133 
Shimogyô 142

shin sangyô toshi see new industrial cities (1962)

shin toshi keikaku hô 1, 38, 39, 40, 45, 48, 67, 105, 108, 133; see also New City

Planning Act or Law (1968)

Shinagawa 79

Shinanogawa 12, 13, 20

Shinbashi 79

shingikai 44, 45, 152, 153, 160, 174

Shinjuku 32, 72

Shinkansen 94, 174

shinkô kôgyô-toshi keikaku see New Industrial City Plan (1930s)

Shiodome 173, 178

shisei see municipal code

Shizuoka 18, 19, 57, 59, 60, 171, 179

Shônai 132

Shoup, Carl Sumner 4, 5, 19, 36, 37, 39, 50; see also Shoup Mission

Shoup Mission (1949-50) 4, 5, 19, 36, 39; see also Kanbe Committee

shûgiin giin, see House of Representatives shûhen chiiki see Peripheral Zone

shûhen toshi see Peripheral Zone and cities within

shukkô 48

shuto kaizô keikaku see Plan for the

Reconstruction of the Capital

shuto kensetsu hô see Capital Construction

Law (1950), National Capital

Construction Law

shuto kensetsu iinkai see National Capital

Construction Committee

shutoken 60-2, 64, 65, 68, 71, 74; see also

Capital Region

shutoken seibi 60-2, 65, 68, 71, 74; see also National Capital Development

shutoken seibi dai ichiji kihon keikaku see First Tokyo Capital Region Plan shutoken seibi hô 62

shutoken seibi kihon keikaku 65, 68, 71, 74; see also National Capital Region Development Plan shutoken seibi kôsô keikaku soan 61; see also conceptual plan for the development of the Capital Region

Simcock, Bradford 108, 118

site improvement along streets 32

social capital 110

Socialist Party (SP) 117, 166

Sômushô see Ministry of Internal Affairs and Communications

Sorensen, André 1, 7, 32, 33, 39, 101, 102,
$105,107-9,113,143,150,151,154$,

164,165

Special City Construction Law 37

Special City Planning Law 60, 64

Special Measures Law on Urban

Regeneration 47

specific-use buildings control area 46

standard of living 47

state as builder $8,167,169,170$

state capitalism 8, 166

statutory planning 137

Steiner, Kurt 104, 116, 118, 178

sub-center 71, 72, 172, 173

Suburban Development Area or Zone 65, $67,68,71,72,75,76,78$

Suburban Green Space Preservation Law (1968) 65

Suburban Zone 61, 62

suggestion system 45

Sunlight Ordinance 39

Super Block Development System 64

sustainability 77,102

Suzuki Zenkô 19

Tachikawa 60, 68, 72, 74, 76

Taga 35

Taisho 55, 114, 116

Tajiri Inejirô 32

Takaoka 28

Takasaki 60, 67

takuchi kaihatsu shidô yôkô see guidelines on land development

takyoku bunsan 71, 74; see also multipolar structure

Tama 10, 18, 57, 67, 72, 78

Tanaka Kakuei 12, 19, 169

Tanaka Yasuo 170

Tapiola 20

taxes on land value increases 31,32

techno-bureaucracy $8,166,168$

technology 10-12, 19, 34, 103

technopolis $8,11-13,20,165$

Third Comprehensive National Development Plan 11, 68, 169

three-in-one reform 47

tochi zôka zei see taxes on land value increases

Tochigi 20, 59, 60, 62, 65, 174, 179

Tôhoku 10, 11, 174

Tôjô Hideki 9

Tôkaidô 14

tokubetsu toshi keikaku hô see Special City Planning Law 
tokubetsu toshi kensetsu hô see Special City Construction Law

tokubetsu yôto chiku 42

tokubetsu yôto seigen kuiki see specific-use buildings control area

Tokugawa 2, 55, 103, 110-2, 141, 142

Tokushima 170, 179

tokutei gaiku seido see Super Block Development System

tokutei hieiri katsudô hôjin see non-profit organization

Tokyo 1-5, 10, 11, 14, 17-20, 25-34, $38-40,42,48-50,55-65,67,68,71-9$, $86,87,93,94,96,103,105,109,113$, $114,116,130-4,142,150,160,164$, $165,170-8$

Tokyo borough area 38

Tokyo Capital Government 4

Tokyo City Assembly 27, 32

Tokyo City Building Ordinance (1906) 28

Tôkyô dai toshi ken see Tokyo

Metropolitan Zone

Tokyo Green Space Plan (1936) 56, 57

Tokyo Metropolitan Assembly 38

Tokyo Metropolitan Government (TMG) $4,5,17,27,29,38,40,42,48,57,58$, $72,73,74,77,78,93,171-3,178$

Tokyo Metropolitan Police Department 32

Tokyo Metropolitan Zone 75

Tôkyô mondai 174

Tokyo Prefectural Assembly 27

Tôkyô ryokuchi keikaku see Tokyo Green Space Plan (1936)

Tôkyô sensai fukkô keikaku see Reconstruction Plan for Tokyo

Tôkyô shiku kaisei jôrei see Tokyo Urban Area Improvement Ordinance

Tokyo Urban Area Improvement Committee 27

Tokyo Urban Area Improvement Ordinance 25, 27, 29, 30, 105

Tokyo Urban Area Improvement Project 26,28

Tôkyô wan kanjô dôro see Bay ring road

Tôkyô-fukai see Tokyo Prefectural Assembly

Tôkyô-kubu see Tokyo borough area

Tôkyô-shi see City of Tokyo (1888-1943)

Tôkyô-shi gikai see Tokyo City Assembly

Tôkyô-to see Tokyo Metropolitan Government

Tôkyô-to chôki sôgô keikaku see LongTerm Plan for the Tokyo Metropolis (1982)
Tôkyô-to gikai see Tokyo Metropolitan Assembly

Tönnies, Ferdinand 111

Toranomon 72

Toshi keikaku Chûô Shingikai see Central City Planning Council

toshi keikaku hô see City Planning Law; see also City Planning Act or Law (1919), New City Planning Act or Law (1968)

toshi saisei kinkyû tokubetsu sochi hô see Special Measures Law on Urban Regeneration

Toshi Sôsaku 34

Toshiba 10, 11

Tottori 93, 179

Town and Village code 3, 179

town-building 128-30, 133, 137; see also machizukuri, community-building

townscape $7,139,140,142,145,146,150$, $151,156-8,160,161$

Toyama $13,28,179$

Toyokawa 35

Toyonaka 132, 136

transfer tax revenue source 48

treasury disbursement 96

Tsuchiura 68, 76

Tsugaru Strait 169

Tsukuba 67, 68, 76

unipolar structure 11, 69, 71, 72

United Kingdom 14

United Social Democratic Party 41

United States of America 3, 4, 7-11, 14, $18,25,31,36,50,88,89,106,109$,

$117,119,129,134,146,149,172,173$

unspecified zones 59

Urawa 68, 76

Urban Building Law 2, 26, 57, 105

urban governance $1,7,101-3,113,122$, 123

urban planning $1-3,7,9,19,25,56,90$, 101-5, 107, 109, 128-34, 137, 138, $150,152,155,167,172,173$

urban population $14,34,110$

urban regeneration 47, 173

Urban Regeneration Areas of Urgent Needs 47

Urban Regeneration Law (1992) 47

urban sprawl 62, 67, 108

Urbanization Promotion Zone 67; see also shigaika kuiki

Ushiku 76

Utsunomiya 12, 60 
voluntary covenants see kenchiku kyôtei Vosse, Wilhelm 110, 120

War Damage Restoration Plan 35

Washo-machi 28

Watanabe Shun-ichi 7, 29, 38, 40, 101, $121,128,130,133,134,140,146,164$, 165

van Wolferen, Karel 8, 178

wooden houses: densely packed 76; traditional 139; see also machiya

World War II 1, 3, 10, 19, 33, 35, 36, 38, $39,50,57,64,78,81,89,90,104,105$, $114,139,143,164$

Yamaboko junkô 144, 145

Yamada Isamu 172

Yamagata 26, 50

Yamaguchi Hanroku 28

Yamanashi 20, 59, 60, 62, 65, 94, 179
Yokohama 4, 5, 18, 19, 33, 34, 37, 38, 55$7,65,67,68,74,76,78,94,131,171$

Yokosuka 60

Yokota military base 172

Yokoyama Nokku 172

yonzensô see Fourth Comprehensive

National Development Plan

yosekiritsu seido see Floor-area Ratio

Regulation System

Yoshino River 170

zaidan hôjin see independent foundation

zeigen ijô see transfer tax revenue source zenkoku sôgô kaihatsu keikaku see

Comprehensive National Plan

zone expropriation 32

zoning 33, 39-41, 45, 50, 57, 61, 67, 105, $107,108,145,155,156,160$

zoning system 40, 45, 67, 105, 107 



eBooks - at www.eBookstore.tandf.co.uk

\section{A library at your fingertips!}

eBooks are electronic versions of printed books. You can store them on your PC/laptop or browse them online.

They have advantages for anyone needing rapid access to a wide variety of published, copyright information.

eBooks can help your research by enabling you to bookmark chapters, annotate text and use instant searches to find specific words or phrases. Several eBook files would fit on even a small laptop or PDA.

NEW: Save money by eSubscribing: cheap, online access to any eBook for as long as you need it.

\section{Annual subscription packages}

We now offer special low-cost bulk subscriptions to packages of eBooks in certain subject areas. These are available to libraries or to individuals.

For more information please contact webmaster.ebooks@tandf.co.uk

We're continually developing the eBook concept, so keep up to date by visiting the website.

www.eBookstore.tandf.co.uk 




